
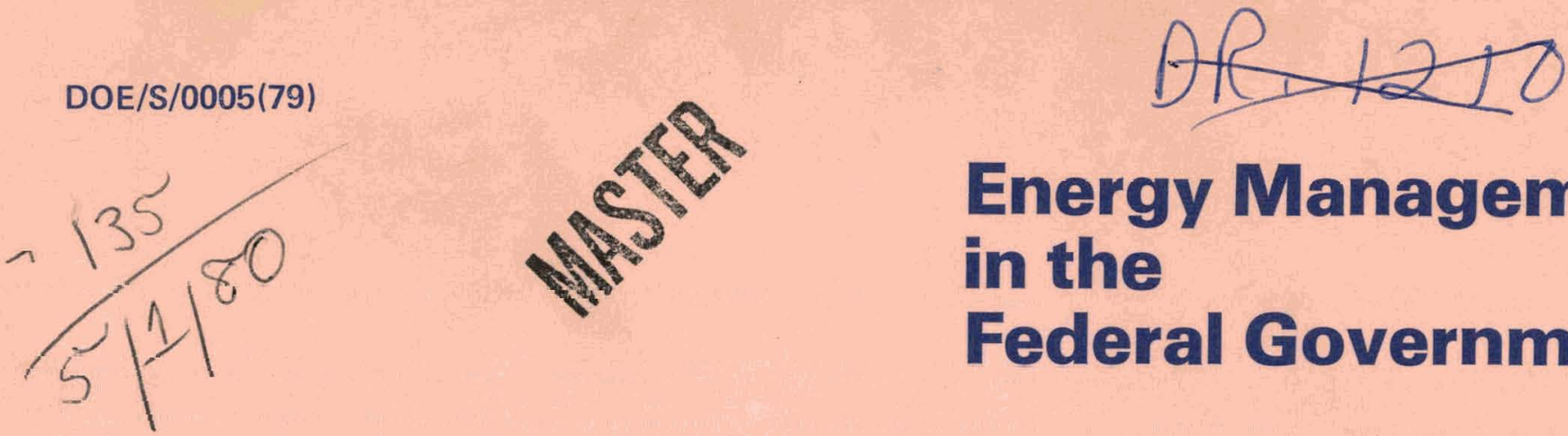

\title{
Energy Management in the \\ Federal Government
}

\section{Annual Report}

United States Department of Energy

Federal Energy Management Program

December 1979

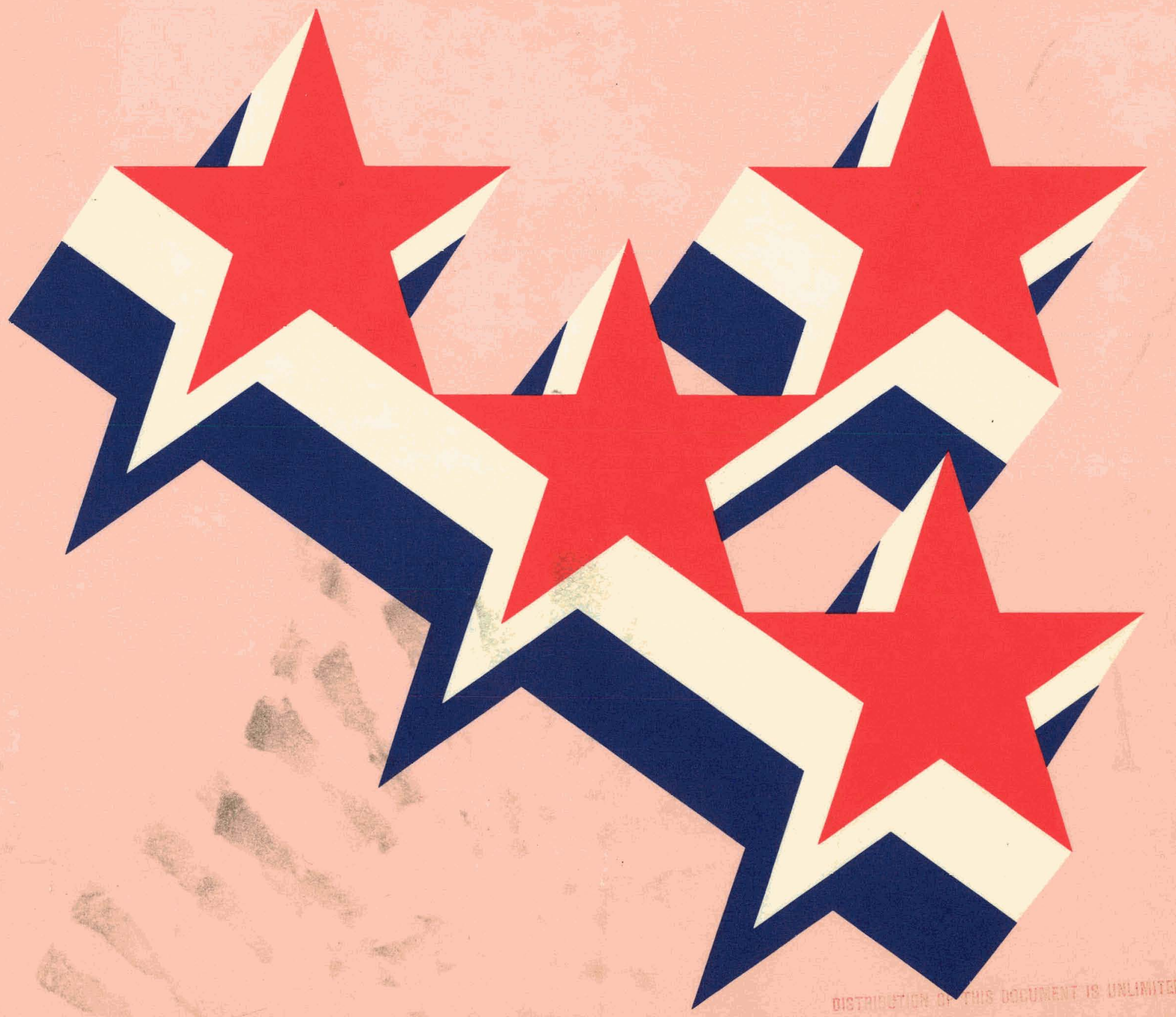




\section{DISCLAIMER}

This report was prepared as an account of work sponsored by an agency of the United States Government. Neither the United States Government nor any agency Thereof, nor any of their employees, makes any warranty, express or implied, or assumes any legal liability or responsibility for the accuracy, completeness, or usefulness of any information, apparatus, product, or process disclosed, or represents that its use would not infringe privately owned rights. Reference herein to any specific commercial product, process, or service by trade name, trademark, manufacturer, or otherwise does not necessarily constitute or imply its endorsement, recommendation, or favoring by the United States Government or any agency thereof. The views and opinions of authors expressed herein do not necessarily state or reflect those of the United States Government or any agency thereof. 


\section{DISCLAIMER}

Portions of this document may be illegible in electronic image products. Images are produced from the best available original document. 
Available from:

National Technical Information Service (NTIS) U.S. Department of Commerce 5285-Port Royal Road

Springfield, Virginia 22161

$\begin{array}{ll}\text { Price: } & \begin{array}{l}\text { Printed copy: } \$ 7.25 / 0 . \\ \text { Microfiche: }\end{array} \quad \$ 3.0050\end{array}$ 


\title{
Energy Management in the Federal Government
}

\author{
Annual Report \\ to the President \\ of the United States \\ Fiscal Year 1978
}

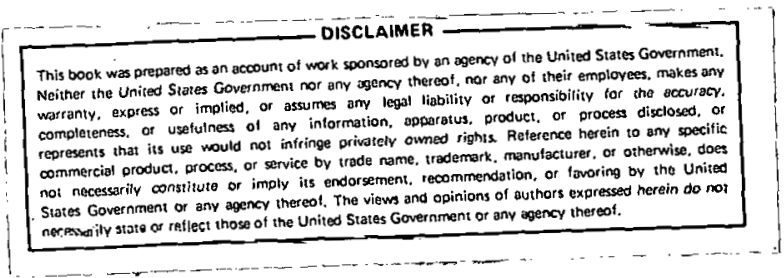

Submitted in Accordance with Executive Order 12003 July 20, 1977 


\section{THE SECRETARY OF ENERGY WASHINGTON, D.C.}

December 7, 1979

MEMORANDUM FOR:

FROM :

SUIRTF.CT:

\section{THE PRESIDENT}

CHARLES $W$. DUNCAN, JR.

Energy Management in the Federal Government Annual Report, FY 1978

This Second Annual Report on Federal Energy Management is . submitted in accordance with your Executive Order 12003 of July 20, 1977.

The report describes executive department and agency performances in energy conservation since FY 1975. It also identifies program problems, corrective actions that are being planned, and new program initiatives.

The Department of Energy believes the report can provide valuable insight both into Federal and national energy problems and into opportunities for Federal leadership through the Federal Energy Management program. Some of the key findings are:

- In FY 1978 total energy use was 5.9 percent lower than the adjusted FY 1975 base year. Conservation activities by the Department of Defense accounted for 97.4 percent of the total amount of energy conserved during the period. These savings are attributed largely to reduced field activities.

- In FY 1978 buildings and facilities energy use was 2.5 percent lower than the adjusted FY 1975 base period.

- Limited progress has been made in reducing reliance on petroleum based fuels. Between FY 1975 and FY 1978, fuel oil use was up roughly 0.4 percent; gasoline use was down 4.2 percent, and the use of aviation fuels was down 7.8 percent. The use of coal decreased approximately 13 percent, but the Department of Defense and the Department of Energy have large construction programs to convert boilers to coal. 
New and revitalized actions with commensurate investments are needed to accelerate the movement toward more efficient use of energy. Without such actions, it is doubtful the goal you established in your Executive Order of a 20 percent reduction in energy use by Federal buildings by 1985 will be met. Several immediate steps appear to be critical:

- The Department of Energy must take a more aggressive leadership role through the establishment and promotion of generally applicable energy management policiee and through monitoring, feedback, and technical assistance. This will require greater resources, top level support from all Federal agencies, and stronger coordination with the Office of Management and Budget. The. Department of Energy will be in the forefront of this effort.

- The reporting of accurate, comparable data must be emphasized by top management in the Department of Energy and the 68 executive departments and agencies involved in the Federal Energy Management Program. Toward this end the Department of Energy will propose the preparation and issuance of detailed guidelines for a sound reporting structure that will show clearly who is responsible for both outstanding and marginal performances.

In sum, the Federal Government has made some progress toward reducing its energy consumption and its initial efforts promise still more reduction of energy use in the future. Nevertheless, the results are uneven and inadequate. Most of the gaing are concentrated in the few agencies that have effective conservation programs. The Federal Government needs to broaden the scope of effective actions to encompass all agencies. It must also expand its programs and particularly its investments in conservation projects, if it is to attain the goals you have set. These efforts will require leadership by the Department of Energy. We will ensure that such leadership is forthcoming.

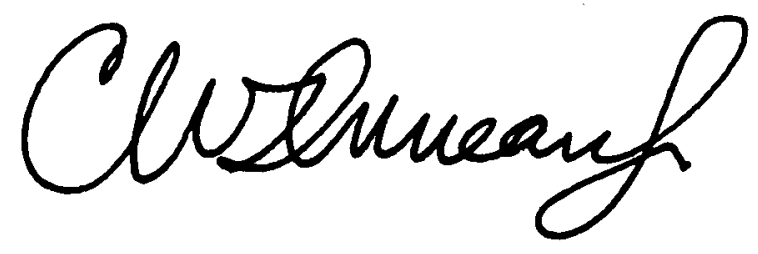




\section{ACKNOWLEDGEMENTS}

The information contained in this report is based in part on materials submitted to the Department of Energy by the Federal agencies involved in the Federal Energy Management Program. DOE wishes to acknowledge its appreciation to these agencies:

\author{
Department of Agriculture \\ Department of Commerce \\ Department of Defense \\ Department of Energy \\ Department of Health, Education, and Welfare \\ Department of Housing and Urban \\ Development \\ Department of the Interior \\ Department of Justice \\ Department of State \\ Department of Transportation \\ Department of the Treasury
}

\section{ACTION}

Administrative Conference of the United States

Agency for International Development

American Battle Monuments Commission

Appalachian Regional Commission

Board for Internatlonal Broadcasting

Central Intelligence Agency

Civil Aeronautics Board

Commission on Civil Rights

Commission of Fine Arts

Commodity Futures Trading Commission

Commodity Services Administration

Consumer Product Safety Commission

Environmental Protection Agency

Equal Employment Opportunity Commission

Export-Import Bank of the United States

Farm Credit Administration

Federal Communications Commission

Federal Deposit Insurance Corporation

Federal Election Commission

Federal Home Loan Bank Board

Federal Maritime Commission

Federal Mediation and Conciliation Service

Federal Reserve System
Federal Trade Commission

Foreign Claims Settlement Commission of the United States

General Services Administration

Inter-American Foundation

Interstate Commerce Commission

Merit Systems Protection Board

National Aeronautics and Space

Administration

National Capital Planning Commission

National Credit Union Administration

National Endowment for the Arts

National Labor Relations Board

National Science Foundation

National Transportation Safety Board

Nuclear Regulatory Commission

Occupational Safety and Health Review

Commission

Office of Management and Budget

Office of Personnel Management

Overseas Private Investment Corporation

Panama Canal Company/Canal Zone

Government

Pennsylvania Avenue Development

Corporation

Pension Benefit Guaranty Corporation

Railroad Retirement Board

Securities and Exchange Commission

Selective Service System

Small Business Administration

Tennessee Valley Authority

United States Arms Control and Disarmament Agency

United States International Communication

Agency

United States International Trade Commission

United States Postal Service

United States 'Soldiers' and Airmen's Home

Veterans Administration 
THIS PAGE

\section{WAS INTENTIONALLY \\ LEFT BLANK}




\section{PREFACE}

This second annual report summarizes the performance of Federal departments and agencies in energy conservation since FY 1975, with special attention being given to 1978 . The Federal energy conservation effort is monitored by the Department of Energy (DOE) and involves the experience of 66 executive departments and agencies.

The report is based on the best available data obtained from agency quarterly energy use reports, agency annual reports and analyses prepared by DOE. Information in quarterly energy use reports received up to September 30,1978 , has been incorporated in to this document.

The annual reports are submitted to the Department of Energy in accordance with the reporting requirements of Executive Order 11912, Section 10, as amended by Executive Order 12003. The agency annual reports are summarized in Appendix $B$ and highlights are presented in Appendix $A$ of this report. These agency reports cover energy used in buildings, facilities, and vehicles that are owned and operated by each agency. Energy use in buildings, facilities, and vehicles owned and controlled by the GSA is included in the GSA report.

Close scrutiny of the data reported to DOE by the various agencies has revealed that it is, on occasion, fragmentary or contradictory. Doubts as to the precision and sufficiency of the reports are appropriate because of the clear failure of some agencies to follow consistent and prescribed standards of measurement. Such omissions and discrepencies in the underlying data precludes statistical exactitude in the report.

Executive Order 12003, of July 20, 1977, established FY 1975 as the base year for the
FEMP Program. Accordingly, the analysis uses FY 1975 as the baseline year and FY 1978 as the comparative year. Due to the fact that the data on energy consumption in the intervening years, FY 1976 and FY 1977, is currently in the process of being revised by key agencies, year by year comparisons are omitted. Energy use and savings information in this report is expressed in terms of millions of barrels of oil equivalent (MBOE) or in trillions of British Thermal Units (Btu $\times 10^{12}$ ). One million barrels of oil equivalent have an energy content of 5.8 trillion Btu $\left(5.8 \times 10^{12}\right)$, while one trillion Btu are equivalent to $0.1724 \mathrm{MBOE}$. To place these units of measure in perspectivc:

- The amount of energy represented by one barrel of oil equivalent (BOE) is sufficient to operate a compact car for 1,000 miles;

- The amount of energy represented by one million barrels of oil equivalent (MBOE) is sufficient to heat more than 40,000 homes for one year;

- The amount of energy represented by one trillion Btu is sufficient to heat more than 7,100 homes for one year.

Very large amounts of energy are measured in Quads. A Quad is one quadrillion $\left(10^{15}\right)$ Btu, roughly equivalent to the amount of energy needed to heat more than $7,100,000$ homes in a year.

Fuel conversion tables are provided in Appendix $F$. The electricity and purchased steam conversion figures incorporate factors which account for generation and distribution efficiency. Thus, they reflect energy use "at the source" rather than "at the building boundary." 
THIS PAGE

WAS INTENTIONALLY

LEFT BLANK 


\section{EXECUTIVE SUMMARY}

\section{Overview}

Energy use within the Federal Government during $F Y 1978$ was 5.9 percent less than the amount consumed in FY 1975. This savings was due primarily to the actions taken by the Department of Defense (DOD), which consumes four-fifths of the energy used by the Federal Government. Figure 1 shows the proportion of DOD energy use in FY 1978 compared to the Federal total. It illustrates the critical role of DOD in meeting the Federal Government's energy goals. The President established energy-saving goals in Executive Order 12003, issued July 20, 1977. These goals are to:

- By 1980 , surpass the annual minimum statutory requirement for automobile fleet average fuel economy by four miles per gallon;

- By 1985 , reduce the average annual energy use in Btu per gross square foot in existing Federal buildings by 20 percent and in new Federal buildings by 45 percent; and

- Establish overall plans for conserving fuel and energy in all other general operations.

The critical nature of DOD's performance in energy use reductions between FY 1975 and FY 1978 is shown in Figure 2, which displays the portion of the 5.9 percent reduction in FY 1978 Federal energy consumption attributable to DOD and the civilian agencies.
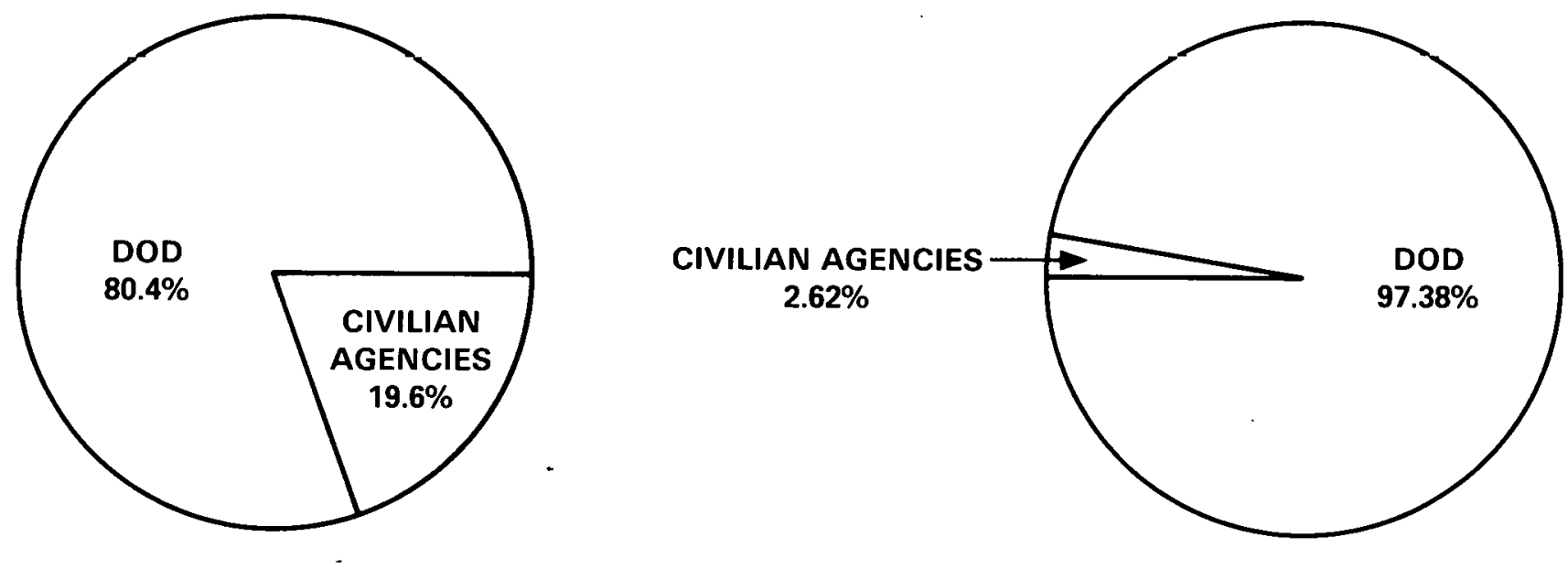

Source: AGENCY QUARTERLY ENERGY USE REPORTS as Submitted to Federal Program Office, U.S. Department of Energy

Figure 1. Portion of Total Federal Energy Used in Major Agencies (FY 1978)
Figure 2. Portion of Total FY 1975-1978 Energy

Use Reduction Attributable to DOD and

Civilian Agencies 
The 5.9 percent reduction in Federal energy use is significant when compared with the increasing trend of national energy use. As shown in Figure 3, the nation as a whole increased its energy consumption by more than 10 percent over the FY $1975-78$ period. In making this comparison, it is recognized that increasing national energy use has been influenced by such variables as increasing population and increasing Gross National Product (GNP), as well as many other variables.

Although the Federal Government's savings since FY 1975 seem significant in comparison to the nation's energy consumption trend, most of these savings resulted from a reduction in the Department of Defense's field operations. The Federal Government has, in fact, only achieved a 2.5 percent reduction in the energy used in the operation of Federal buildings and facilities. Unless actions are taken to change this current trend, it is doubtful that the 1985 goal of an overall reduction of 20 percent for Federal buildings will be met.

The analyses used in the preparation of the report indicate a number of significant findings. A brief summary of these findings follows:

- With present data reporting systems, the average Btu used per gross square foot in Federal agencies' buildings is undeter-

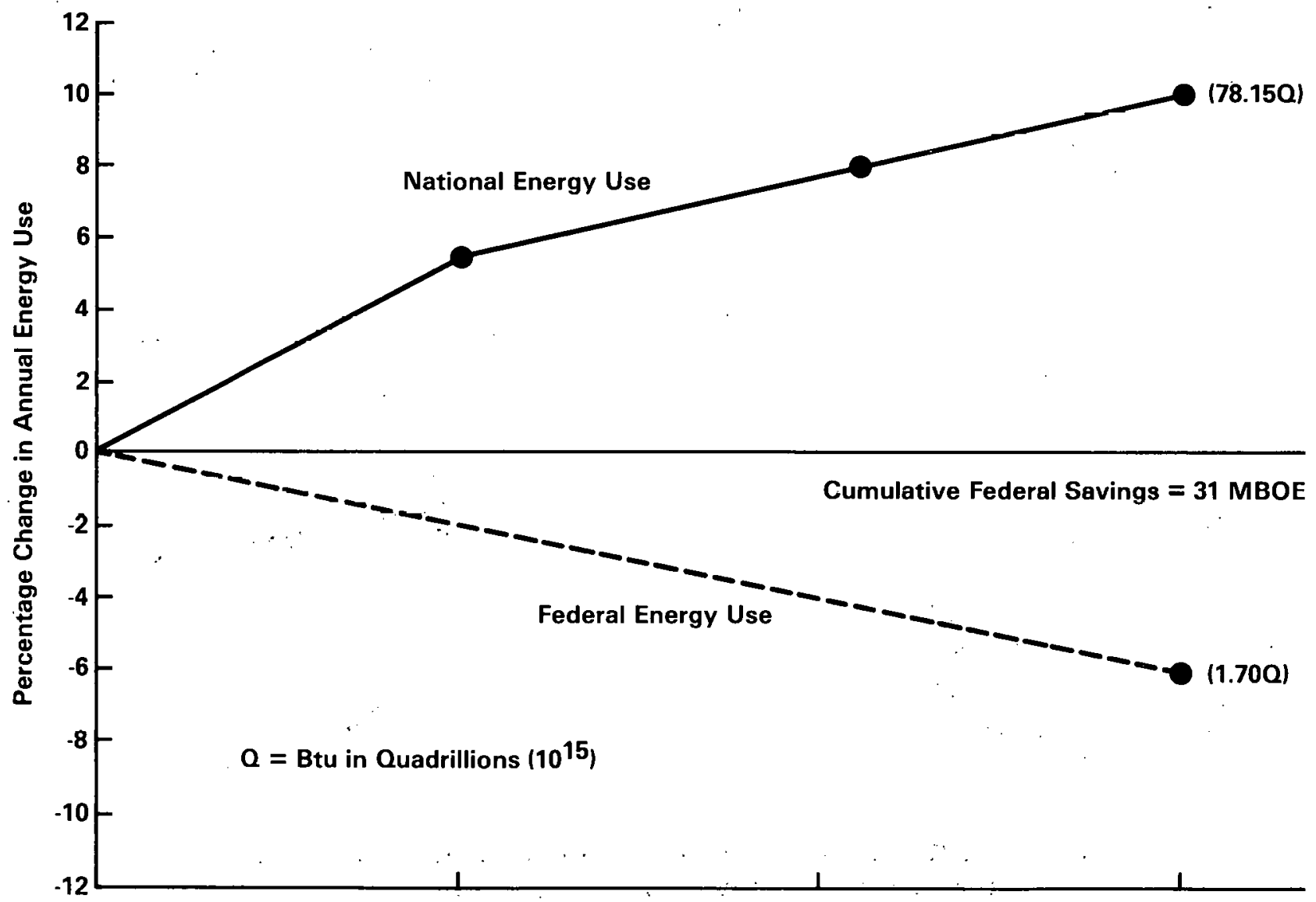

FY 1975

FY 1976

FY 1977

FY 1978

\section{Calendar Years}

Source: Energy Information Administration, MONTHLY ENERGY REVIEW; DOE Quarterly Energy Use Reports

Figure 3. Federal and National Energy Use

Trends, FY 1975-1978 
minable. There is no assurance that reported building energy use corresponds with separately reported building square footages.

- Agency-reported goals for buildings were inconsistent with those goals mandated by Executive Order 12003. Many agencies' goals were not stated in Btu per gross square foot. Those which were did not necessarily call for a 20 percent reduction by 1985 . Those goals that were reported for general operations are inconsistent, and vary more widely than differences in agency missions and functions would seem to explain.

- Severe problems exist in the data contained in the agency reports. They were inconsistent in format and contain internal data inconsistencies. Essential data elements were missing in many agency reports e.g., information about leased buildings energy use is very fragmentary.

- Reduction in overall Federal energy use is highly dependent on conservation actions in DOD. Within DOD, reduction in energy use is most sensitive to changes in the use of jet fuel.

- To date, Federal Erıergy Management Pro. gram reports of total energy use have excluded the energy used by DOE in its uranium enrichment plants and nuclear reactors in Savannah, Georgia. This exclusion is due in part to the strategic nature of plant operations. Some energy is con. verted into stored energy in the form of nuclear fuel and weapons material. In FY 1978, DOE figures indicate that its nuclear facilities used 393.2 trillion Btu of electrical energy which is equal to 22.6 percent of the total reported Federal energy use.

- The planned shift toward coal has not materialized. Coal use in Fy 1978 was 13.2 percent below the corresponding level in FY 1975.

- There has been a favorable change in FY 1978 gasoline consumption. Usage is down 4.2 percent from corresponding FY 1975 levels.
In the successful Federal energy conservation programs that were analyzed, certain key management elements were found. They were:

- Top Management Commitment. Top management must have a personal and sustained commitment to the agency's program, provide active direction and motivation, and require regular review of overall energy use at senior staff meetings.

- Line Management Accountability. Line managers must be accountable for the energy conservation performance of their organizations and should participate in establishing realistic goals and developing strategies and budgets to meet these goals.

- Formal Planning. A comprehensive 10-year plan must be developed and formalized which sets forth specific performanceoriented conservation goals.

- Goals. Goals must be established in a measurable manner to answer the questions of "Where are we?"; "Where do we want to go?"; and "Are we getting there?".

- Monitoring. Progress must be reviewed periodically both at the agency headquarters and at local facility levels to identify program weaknesses or additional areas for conservation action. Progress toward achievement of goals is assessed, and explanations for non-achievement or unusual variations in energy use are required. Monitoring includes personal inspections ańd staff visits, management information reporting, and audits.

- Use of Technical Expertise. Personnel with adequate technical background and knowledge of programmatic objectives are used to help management set technical goals and parameters for efficient planning and implementation of energy conservation programs.

- Employee Awareness. Employees must gain an awareness of energy conservation through formal training and employee in. formation programs. They are invited to participate in developing an energy conservation program and to submit suggestions for conservation. 
- Energy Emergency Planning. Every energy management plan should provide for optional programs to respond to contingencies such as the recent curtailment of crude oil imports.

- Budgetary and Fiscal Support. Resources necessary for the energy conservation pro. gram must be planned for and provided.

To achieve the President's goals for the efficient use of energy, all Federal agencies must adopt these practices.

\section{Energy Use by Agency}

Table 1 shows Federal Government Energy Use from FY 1975 through FY 1978 for the 18 largest energy using agencies. A consolidated total is shown for eight other agencies. Energy use is reported in the "General Operations" and "Buildings" categories specified in Executive Order 12003 . The flgures have not been adjusted for climatic factors which can cause significant fluctuations in energy requirements from one year to the next.

Based upon the information in Table 1, a number of important findings emerge:

- Federal agency energy consumption was reduced 5.9 percent between FY 1975 and FY 1978.

- Cumulative energy use avoidance between FY 1975 and FY 1978 totaled approximately 31 million barrels of oil equivalent (MBOE).

- 79 percent of the total conservation achieved during the period was attributable to general operations while 21 percent of the savings was a result of conservation in buildings and facilities.

- Energy used in general operations was reduced 9.3 percent largely as a result of the reduction in the use of jet fuel by the Department of Defense.

- Energy consumption in buildings and facilities was reduced 2.5 percent through decreases in the use of natural gas and coal.

- Ten of the 18 largest agencies did not reduce energy consumption in FY 1978 based on the level of consumption in FY 1975.

A major conclusion to be drawn is that while some absolute reductions in total energy use have been achieved, the successes are not uniform among agencies. Although these findings do not necessarily indicate the program is stagnating, they are cause for concern and will be more thoroughly investigated by DOE in the coming months.

\section{Federal Energy Use Avoidance}

During FY 1978, the Federal Government used nearly 2.2 percent of total national energy use, or 1.70 quadrillion Btu. This was 5.9 percent less than the amount used in FY 1975. Between FY 1975 and FY 1978, Federal reliance on petroleum based fuels decreased, due to reduced use of diesel and aviation fuels. As illus. trated in Figure 2, this reduction is due almost entirely to actions taken by the Department of Defense.

Federal energy use is reported in two major eategories: General Operations and Buildings.

\section{General Operations}

The General Operations Energy Management Program includes the energy used by Federal agencies to perform their daily missions and functions other than for the operation of buildings. In FY 1978, the energy used for general operations was 9.3 percent less than that in FY 1975. This is a reduction of 14.5 MBOE compared to FY 1975. The cumulative saving between FY 1975 and $F Y 1978$ was about $23 \mathrm{MBOE}$, with most of the reduction achieved in FY 1978. Civilian agencies as a whole actually increased their energy consumption in this area by 7.5 percent. Only DOD, which used about 94 percent of the total energy used in general operations, has shown a continuous downward trend over the entire period. Eleven of the 18 largest using agencies had higher general operation's energy use in FY 1978 than they did in the FY 1975 base year.

These mixed results have not been adjusted for changes in agency missions: For example, the Department of Transportation has experienced increased energy use since FY 1975 due to the additional responsibilities of the U.S. Coast Guard for monitoring the 200-mile Fisheries Management Zone and for increased drug interdiction efforts. Energy use in the 
TABLE 1. Federal Government Energy Use FY 1975 to FY 1978

Energy Use in Billions (Btu $\times 10^{9}$ ) of Btu and Million Barrels of Oil Equivalent (MBOE)

\begin{tabular}{|c|c|c|c|c|}
\hline & $\begin{array}{c}\text { FY } 1975 \\
\text { Total } \\
\text { Btu } \times 10^{9}\end{array}$ & $\begin{array}{c}\text { FY } 1976 \\
\text { Total } \\
\text { Btu } \times 10^{9}\end{array}$ & $\begin{array}{c}\text { FY } 1977 \\
\text { Total } \\
\text { Btu } \times 10^{9}\end{array}$ & $\begin{array}{c}\text { FY } 1978 \\
\text { Total } \\
\text { Btu } \times 10^{9}\end{array}$ \\
\hline DOD & $1,466,706.1$ & $1,431,307.7$ & $1,427,633.4$ & $1,362,746.7$ \\
\hline DOE & $86,816.1$ & $87,204.5$ & $85,841.1$ & $87,031.2$ \\
\hline USPS & $55,510.0$ & $55,018.2$ & $58,941.0$ & $54,912.8$ \\
\hline GSA & $44,868.7$ & $43,836.3$ & $43,785.5$ & $44,622.9$ \\
\hline VA & $39,207.5$ & $36,467.3$ & $37,925.0$ & $39,444.9$ \\
\hline DOT & $26,834.5$ & $27,013.1$ & $28,315.4$ & $28,431.3$ \\
\hline NASA & $27,244.8$ & $25,866.2$ & $24,080.0$ & $22,479.5$ \\
\hline DOI & $12,449.8$ & $14,909.1$ & $15,219.2$ & $12,426.9$ \\
\hline Agriculture & $11,928.8$ & $11,606.7$ & $10,722.8$ & $11,222.8$ \\
\hline HEW & $9,259.5$ & $9,590.1$ & $9,917.3$ & $9,439.2$ \\
\hline Justice & $6,689.7$ & $7,172.1$ & $7,359.3$ & $7,167.3$ \\
\hline Treasury & $4,238.7$ & $4,184.7$ & $4,268.5$ & $4,322.3$ \\
\hline Commerce & $3,515.7$ & $3,869.1$ & $3,830.9$ & $3,792.4$ \\
\hline Panama Canal & $2,705.1$ & $2,528.7$ & $2,626.0$ & $2,516.4$ \\
\hline Labor & $1,578.3$ & 1.631 .8 & $1,757.7$ & $1,771.2$ \\
\hline TVA & 764.3 & 900.8 & $1,151.3$ & $1,081.2$ \\
\hline EPA & 559.8 & 564.1 & 557.4 & 595.4 \\
\hline HUD' & 375.0 & 308.1 & 315.5 & 336.5 \\
\hline Others $^{2}$ & $614.6^{\circ}$ & 278.8 & 388.0 & 772.1 \\
\hline Total Btu $\times 10^{9}$ & $1,801,867.0$ & $1,764,257.4$ & $1,764,535.3$ & $1,695,113.1$ \\
\hline MBOE & 310.7 & 304.2 & 304.2 & 292.3 \\
\hline \multicolumn{2}{|c|}{$\begin{array}{l}\text { Annual Savings From FY } 1975 \\
\text { Btu } \times 10^{9}\end{array}$} & $37,609.6$ & $37,331.7$ & $106,753.9$ \\
\hline \multicolumn{2}{|l|}{ MBOE } & 6.5 & 6.4 & 18.4 \\
\hline \multicolumn{2}{|c|}{$\begin{array}{l}\text { Cumulative Savings From FY } 1975 \\
\text { Btu } \times 10^{9}\end{array}$} & $37,609.6$ & $74,941.3$ & $181,695.2$ \\
\hline \multicolumn{2}{|l|}{ MBOE } & 6.5 & 12.9 & 31.3 \\
\hline
\end{tabular}

Footnotes on following page are an integral part of this table. 


\section{FOOTNOTES}

1. The figures in this table differ from some figures in the FY 1977 Federal Energy Management Report; that Report showed 1,704.57 trillion Btus consumed in FY 1975 by all agencies. The reasons for the differences are:

In last year's report, DOD's total energy use was given as 1,307.77 trillion Btu in FY 1975: The FY 1978 Report reflects the addition by DOD of building energy use outside the United States. Adjustments between categories resulting from more accurate reporting are present each year from FY 1975 through FY 1977.

DOE total energy use in FY 1975 was given as 83.63 trillion Btu in the 1977 report. The FY 1978 Report includes the energy used in programs transferred to DOE from DOI for FY 1975 and FY 1978. Revisions to FY 1976 and FY 1977 data have not been completed. However, the FY 1977 total is estimated to be 88.82 trillion Btu.

DOI total energy use in FY 1975 was given as 14.78 trillion Btu. The FY 1978 Report reflects adjustments of FY 1975 and $F Y 1978$ energy use resulting from mission responsibilities transferred to DOE. Revisions to FY 1976 and FY 1977 data have not been completed.

Additional minor differences from agency data presented in the FY 1977 Federal Energy Management Program Report are due to rounding to trillion Btu inthe FY 1977 Report and audit adjustments associated with more accurate reporting. Columns may not add due to rounding.

2. "Other" agencies include Small Business Administration Office of Personnel Management, Civil Aeronautics Board, Federal Communications Commission, Department of State, Interstate Commerce Commission and Office of Management and Budget. The FY 1978 Report reflects National Science Foundation data for FY 1975 and FY 1978. NSF data have not been added to the FY 1976 and FY 1977 reports. 
Department of Defense has been impacted by NATO exercises and other operational training.

\section{Buildings}

Twenty-two agencies own about 3.2 billion square feet of floor space in more than 490,000 buildings worldwide. These buildings include offices, warehouses, hospitals, schools, and houses, etc. The Department of Defense is the largest building owner. Other agencies own more than 95,400 buildings totaling 756 million square feet of floor space. Six agencies account for 94 percent of the total energy used in Federal buildings, as shown in Figure 4.

\section{Existing Buildings Program Area}

The primary target for energy conservation is decreased use of energy in existing buildings.

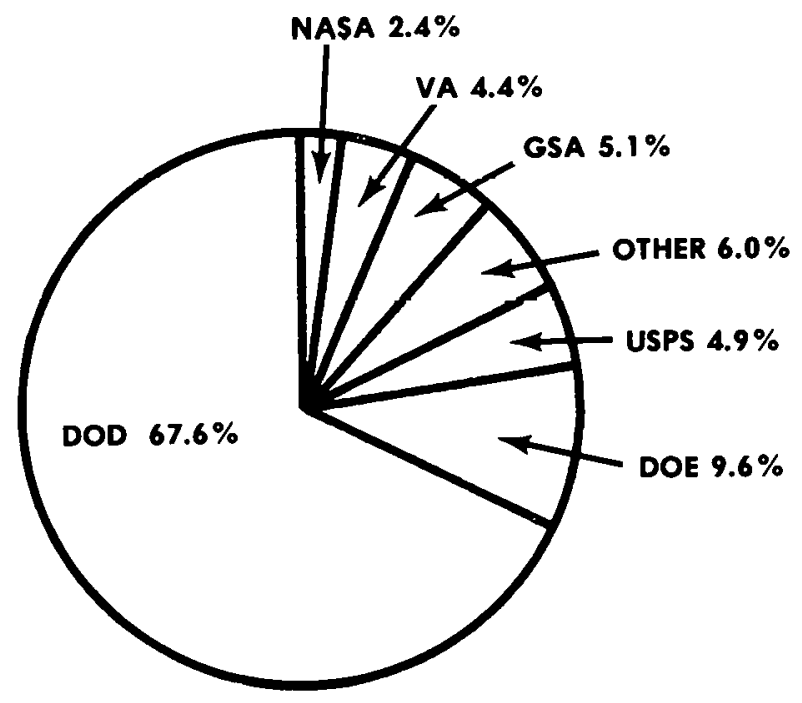

Figure 4. DOD and Civilian Agencies Percentages of Total Building Energy Use in FY 1978.

The vast majority of energy use reductions for Federal buildings by 1985 will be attributable to either modifications in building operations and maintenance or to retrofit of electrical, mechanical, and structural systems. A small portion of the overall reduction will be obtained through the growing inventory of new, more energy efficient buildings.

In FY 1978, the Federal Government used 2.5 percent less energy in buildings than during $F Y$
1975. The cumulative energy use avoidance between FY 1975 and FY 1978 was about 8 MBOE. However, nine of the 18 largest energy using agencies showed higher total energy use in buildings during FY 1978 than during FY 1975. Unless actions are taken to change this current trend, it is doubtful that the $1985 \mathrm{goal}$ of a 20 percent reduction in energy use per gross square foot for buildings by 1985 will be achieved.

\section{Future Activities and Program Recommendations}

Some Federal agencies have developed exceptionally well balanced and effective energy management programs. Most agencies, however, are having a difficult time in their efforts to conserve energy. There are many improvement that can be made to revitalize the effectiveness of the overall effort within the Federal Government. These are:

- Obtaining top management commitment from each Federal agency;

- Providing a uniform planning methodology and rectifying data inconsistencies;

- Reducing energy use in agencies where it has been on the increase in recent years;

- Improving the critical fuels management program.

A look at the total Federal energy use picture of the past few years signals the urgent need for a strong DOE leadership effort. This effort should revitalize and strengthen the Federal Government's energy management efforts. It will emphasize energy efficiency and increased productivity.

DOE plans to recapture the original momentum of the FEMP by establishing a strong, costeffective management effort which will draw top management support and a renewed teamwork spirit within all Federal agencies. The program will meet legislative mandates to promote energy efficiencies and prudent resource management. Top management guidance, plans, standards, procedures, and technical budgetary recommendations will be provided by DOE. Special attention will be given to assure that urgently needed contingency plans are developed and cost-effective investment pro- 
grams are implemented. Data deficiencies will be resolved to assure that an accurate data base is developed to support effective energy management.
These activities will not only result in a more productive Federal Energy Management Program, but should also seek to become a conservation showcase for the nation. 


\section{TABLE OF CONTENTS}

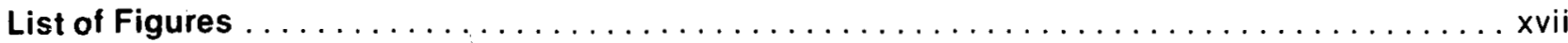

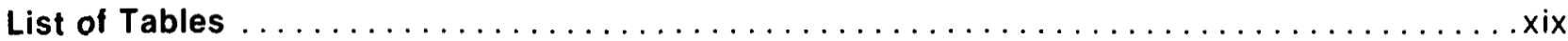

Chapter $I-$ Introduction and Background $\ldots \ldots \ldots \ldots \ldots \ldots \ldots \ldots \ldots \ldots \ldots \ldots \ldots \ldots \ldots \ldots$

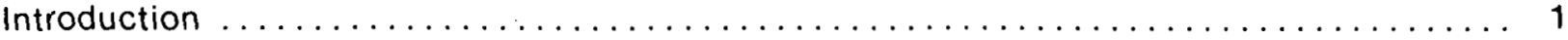

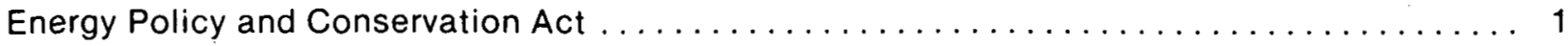

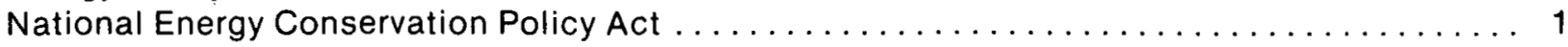

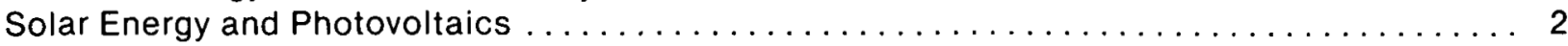

Presidential Memoranda ................................... 2

Roles of Department of Energy and Other Federal Agencies $\ldots \ldots \ldots \ldots \ldots \ldots \ldots \ldots \ldots 2$

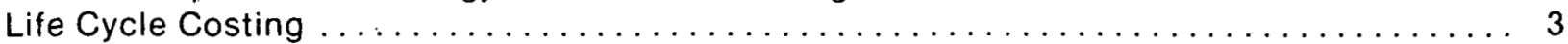

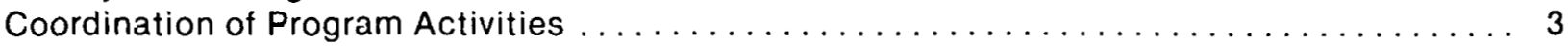

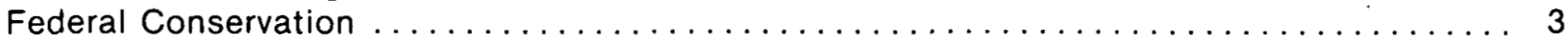

Impact of Federal Coneervation on the Public Eector $\ldots \ldots \ldots \ldots \ldots \ldots \ldots \ldots \ldots \ldots \ldots \ldots$

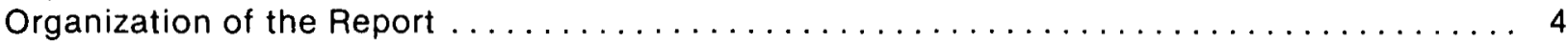

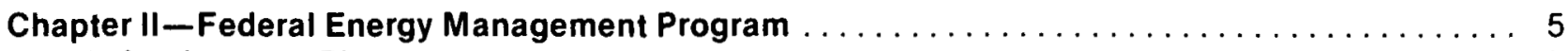

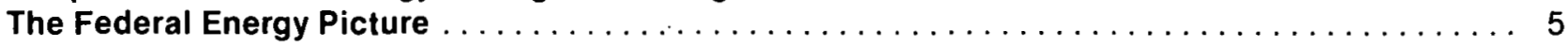

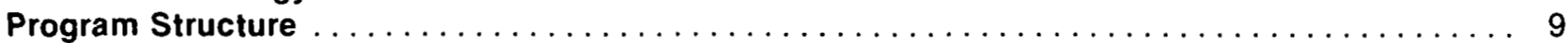

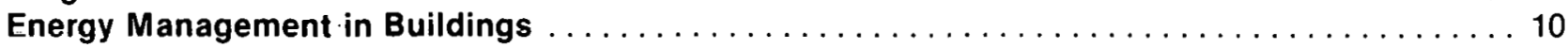

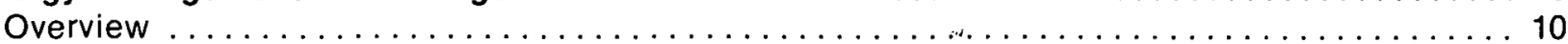

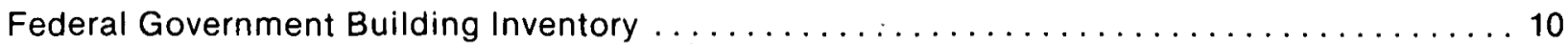

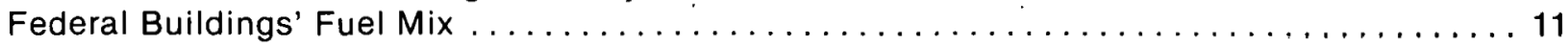

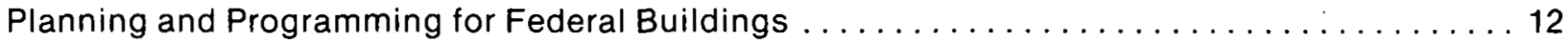

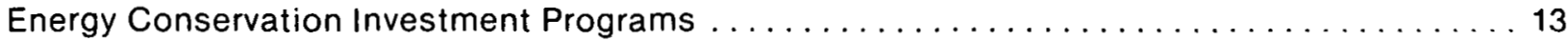

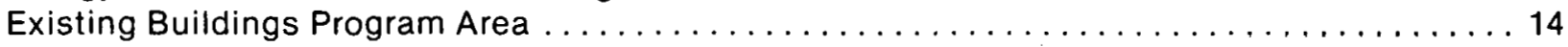

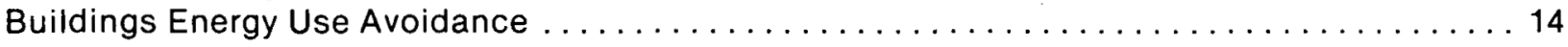

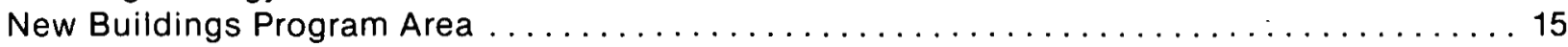

Non-Critical and Renewable Energy Sources for Buildings $\ldots \ldots \ldots \ldots \ldots \ldots \ldots \ldots \ldots \ldots$

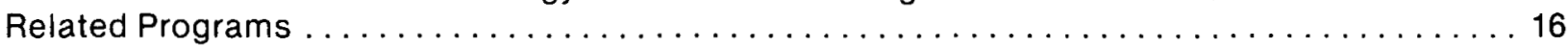

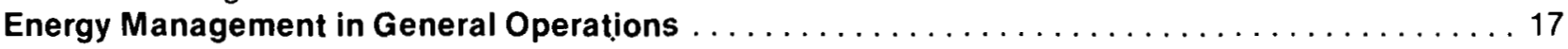

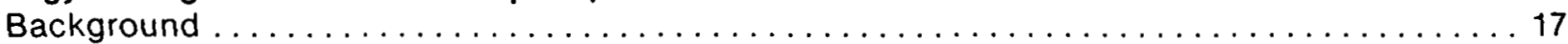

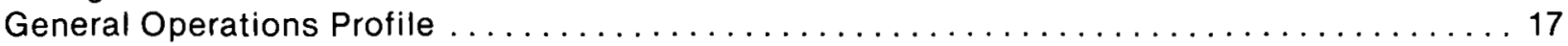

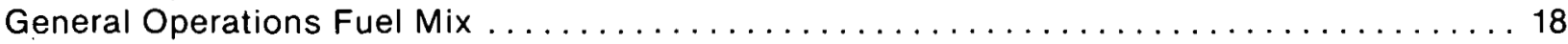

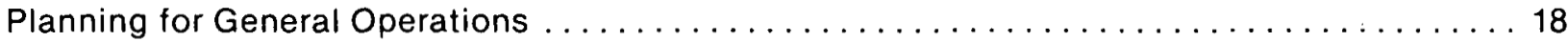

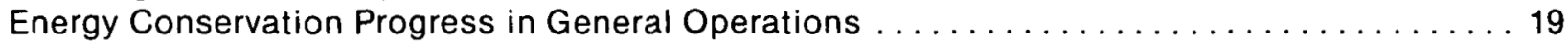

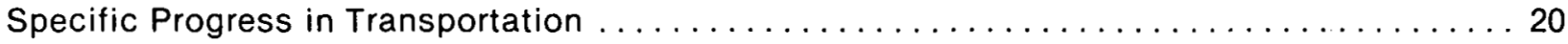

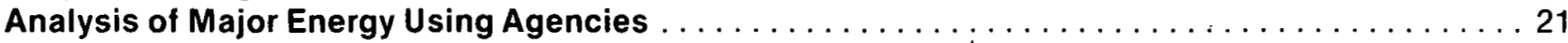

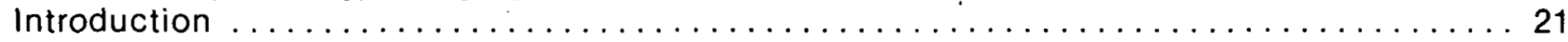

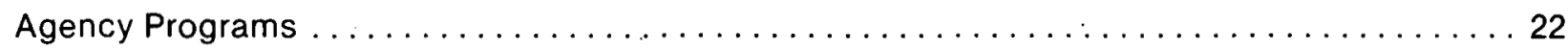

Agency Reporting Chronology and Associated Problems $\ldots \ldots \ldots \ldots \ldots \ldots \ldots \ldots \ldots \ldots 22$

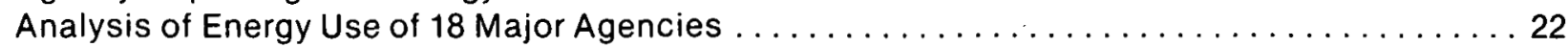

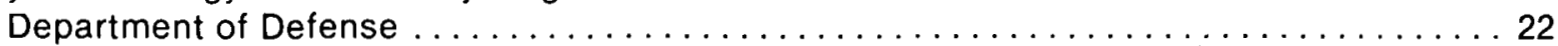

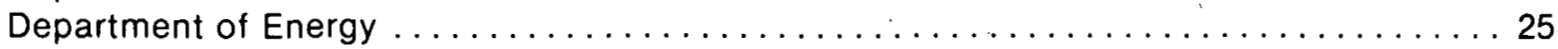

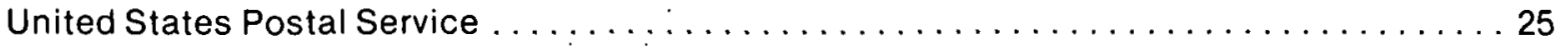

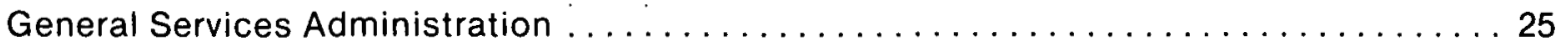

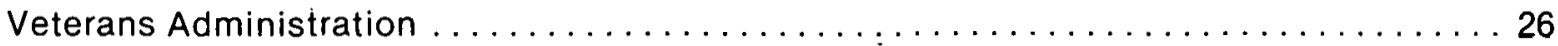

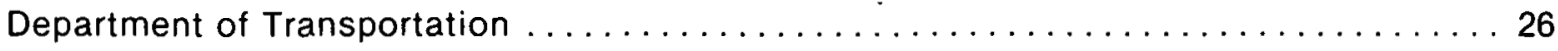

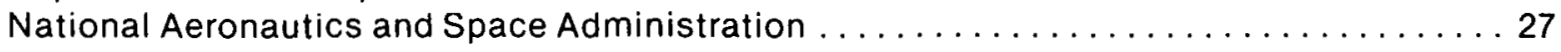




\section{TABLE OF CONTENTS}

\section{CONTINUED}

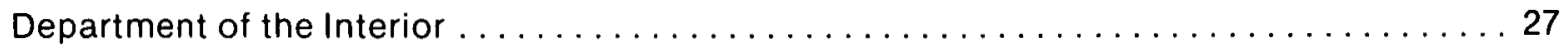

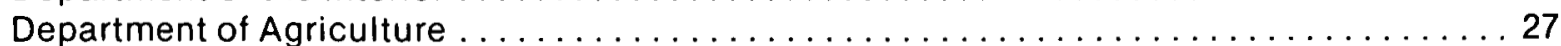

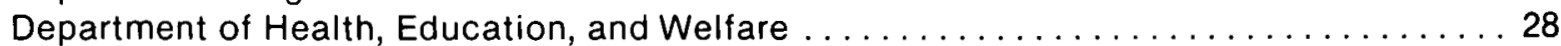

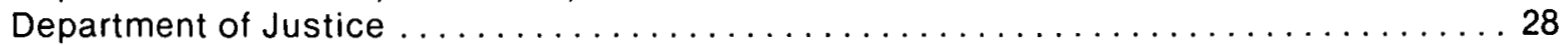

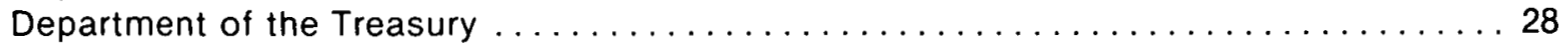

Department of Commerce . . . . . . . . . . . . . . . . . . . . . . . . 29

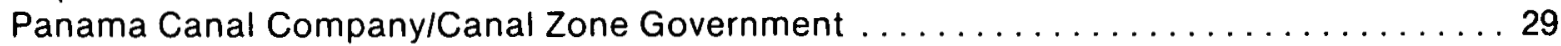

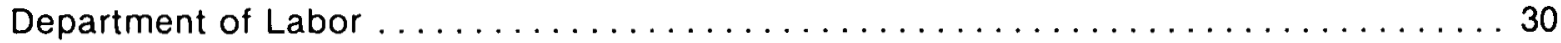

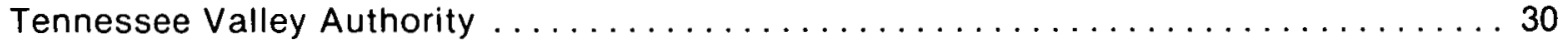

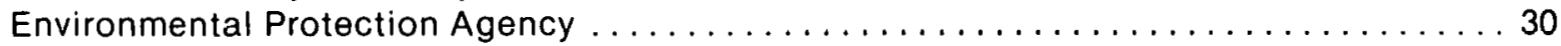

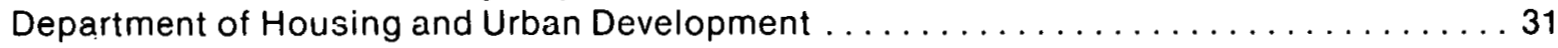

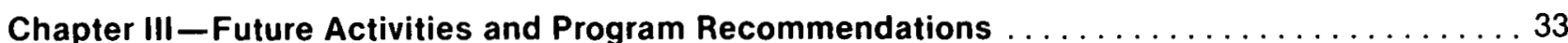

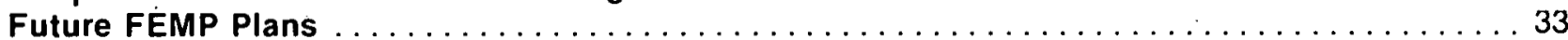

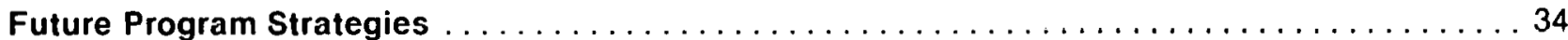

\section{APPENDICES}

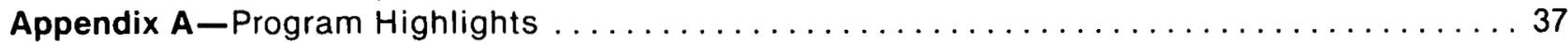

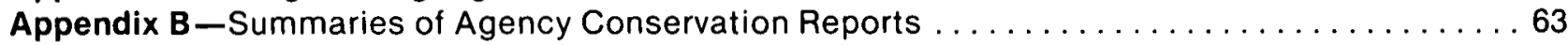

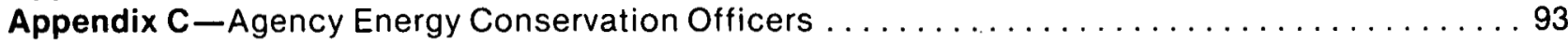

Appendix D-Authorities-Legislation, Executive Orders, Policies and Regulations . . . . . . . 95

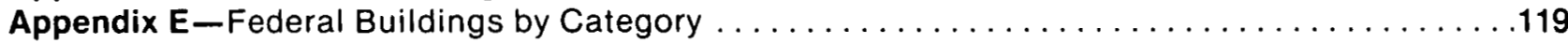

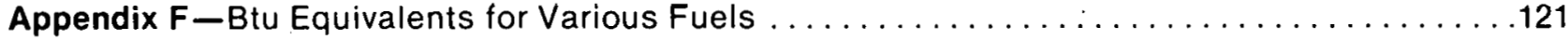




\section{LIST OF FIGURES}

Title

Page

Portion of Total Federal Energy Used by Major Agencies (FY 1978)

Portion of Total FY 1975-1978 Energy Use Reduction Attributable to DOD

vii and Civilian Agencies

Federal and National Energy Use Trends, FY 1975-1978

vii

viii

DOD and Civilian Agencies' Percentages of Total Building Energy Use in FY 1978

Federal Energy Consumption Mix FY 1975 and FY 1978

xiii

Number of Federally Owned Sedans by Categories

Federal and National Fleet Average MPG for New Car Purchases

Evaluation of Agency Reports Against a Comprehensivc Program Spectrum

2.5 Evaluation of Agency-Submitted Data Items Against a Comprehensive Data Spectrum

2.6 Percent Change in Total Energy Use by the Department of Defense Compared to FY 1975 Baseline

2-7 Percent Change in Total Energy Use by the Department of Energy Compared to FY 1975 Baseline

Percent Change in Total Energy Use by the United States Postal Service Compared to FY 1975 Baseline

2-9 Percent Change in Total Energy Use by the General Services Administration Compared to FY 1975

2.10 Percent Change in Total Energy Use by the Veterans Administration Compared to FY 1975 Baseline

2-11 Percent Change in Total Energy Use by the Department of Transportation Compared to FY 1975 Baseline

2.12 Percent Change in Total Energy Use by the National Aeronautics and Space Administration Compared to FY 1975 Baseline

2.13 Percent Change in Total Energy Use by the Department of Interior Compared to FY 1975 Baseline

2-14 Percent Change in Total Energy Use by the Department of Agriculture Compared to FY 1975 Baseline

2-15 Percent Change in Total Energy Use by the Department of Health, Education, and Welfare Compared to FY 1975 Baseline

2-16 Percent Change in Total Energy Use by the Department of Justice Compared to FY 1975 Baseline

2-17 Percent Change in Total Energy Use by the Department of Treasury Compared to FY 1975 Baseline

2.18 Percent Change in Total Energy Use by the Department of Commerce Compared to FY 1975 Baseline

2-19 Percent Change in Total Energy Use by the Panama Canal Companyl 


\section{LIST OF FIGURES \\ CONTINUED}

Figure

Title

Page

2-20 Percent Change in Total Energy Use by the Department of Labor

30 Compared to FY 1975 Baseline

2-21 Percent Change in Total Energy Use by the Tennessee Valley Authority Compared to FY 1975 Baseline

$2-22$

Percent Change in Total Energy Use by the Environmental Protection Agency Compared to FY 1975 Baseline

2-23 Percent Change in Total Energy Use by the Department of Housing and Urban Development Compared to FY 1975 Raseline. 


\section{LIST OF TABLES}

\begin{tabular}{llr} 
Table & \multicolumn{1}{c}{ Title } & Page \\
\cline { 3 - 4 } 1 & Federal Government Energy Use FY 1975 to FY 1978 & xi \\
$2-1$ & Federal Government Energy Use FY 1975 to FY 1978 & 7 \\
$2-2$ & Major Fuel Types Used in Federal Buildings & 11 \\
$2-3$ & Major Fuel Types Used in General Operations & 18
\end{tabular}




\section{INTRODUCTION AND BACKGROUND}

\section{Introduction}

The Federal Energy Management Program (FEMP) represents a concerted effort to develop energy conservation and management techniques at the Federal level. Established in 1973 , the program has sought to establish the viability of energy management and conserva. tion techniques through actual demonstrations within executive departments and Federal agencies. It is hoped that by establishing the viability of energy conservation at the Federal level, the general public will be encouraged to replicate these experiences nationwide.

As a direct result of the combined efforts of Federal agencies and executive departments participating in the Federal Energy Management Program, total energy use within the Federal Government during FY 1978 was 5.9 percent less than the amount consumed in $F Y$ 1975.

It is difficult to pinpoint any one single program or policy that has been most effective in reducing energy consumption at the Federal level. It is likely instead that the myriad of programs overseen by FEMP have combined synergistically to reduce overall energy consumption. These programs are described in detail below in the introduction to this report. The remaining chapters provide information on the overall energy picture, Federal energy management, future activities and program recommendations, and program highlights. Information that is more background in nature is presented in appendices to the report.

\section{Energy Policy and Conservation Act}

In late 1975, legislation was enacted and an Executive Order issued to strengthen previous Federal energy conservation efforts. The Energy Policy and Conservation Act (EPCA) (Public Law 94-163) formalized the ongoing Federal activities and established direct $r \theta-$ quirements for Federal energy conservation programs in the areas of transportation, buildings, procurement policies and standards.
Executive Order 12003, issued July 20, 1977, established the following goals using FY 1975 as the base year for measurement:

- By 1980, exceed the annual minimum statutory requirement for automobile fleet average fuel economy by four miles per gallon.

- By 1985, reduce the average annual use in Btu per gross square foot in existing Federal buildings by 20 percent.

- By 1985 , reduce the average annual use in Btu per gross square foot in new Federal buildings by 45 percent.

- Establish overall goals and plans for con. serving fuel and energy in all other opera. tions.

- Identify and undertake those projects that are life cycle cost effective in order to achieve established goals.

\section{National Energy Conservation Policy Act}

Enactment of the National Energy Conserva. tion Policy Act (NECPA) (Public Law 95-619) in 1978 served to further reinforce and to strengthen present energy conservation efforts. NECPA requires Federal rules for the establishment of practical and effective methods for estimating and comparing life cycle costs for Federal buildings. These are currently in the process of being published. In preparation for the NECPA retrofit requirements, agencies have performed preliminary energy audits on most buildings over 30,000 gross square feet (gsf) and are expected to complete audits on other buildings in FY 1980. The results of these preliminary energy audits are contained in Report to Congress on the Results of the Preliminary Energy Audits (Vol. I, FY 1978).

Final publication of the Federal procedures for preliminary energy audits and guidelines for developing agency ten year buildings plans will 
serve to enhance ongoing energy conservation efforts in Federal buildings and will provide a basic framework for energy management in the Federal agencies. Under these new guidelines, a major benefit of energy cost avoidance will be an increasingly favorable return on initial capital investments.

\section{Solar Energy and Photovoltaics}

NECPA also contained authorization for the demonstration of solar heating and cooling in Federal buildings and Federal photovoltaic utilization. The purpose of the Solar Federal Buildings Program is to stimulate the growth of the solar energy industry by building Federal Demonstration projects. This will be accomplished by providing funds to Federal agencies over a three year period for the design, construction, and installation of a variety of com. merclally applicable solar energy systems in new and existing Federal buildings. The Federal Photovoltaic Utilization Section of NECPA established a three-year market development program which calls for the procurement and installation of photovoltaic systems in Federal facilities. The effort is a direct continuation of the Federal procurement program which began under Section 208 of the Department of Energy Act of 1978. The purpose of the program is to encourage market development in commercial markets as well as in the Federal sector. To this end, the program must support those applications that have been identified as having significant potential in the private market as well as in Federal agencies.

\section{Presidential Memoranda}

Early in FY 1979, the President issued two memoranda directing the Federal Government to implement aggressive programs to further reduce energy use.

The memorandum of February 2, 1979, was issued following a period of political unrest in Iran and associated petroleum supply interruptions. In it, the President directed executive departments and agencies to take immediate steps to reduce the use of petroleum fuels. Specific actions to be taken included the lowering of winter thermostat settings, a reduction in the use of electricity, the deferral of agency research, development, and experimental activ. ities that were highly energy intensive, and the elimination of unnecessary vehicle trips. Em. phasis was also placed on the development of employee energy awareness, the promotion of car pools, and the use of mass transit.

The memorandum of April 10, 1979, was issued following a meeting of the International Energy Agency. As a result of this meeting, the U.S. took the lead among the member nations to reduce petroleum use. This step resulted in a Presidential commitment "to reduce oil imports by a level equal and up to five percent of projested domestic consumption." In this memorandum, the President directed the heads of executive departments and agencies to participate in this goal through reducing energy consumption by five percent for the 12-month period beginning April 1, 1979, compared to the preceeding 12 months.

Specific actions required under the memorandum include:

- Setting thermostats in all Federallyoperated buildings at not more than $65^{\circ} \mathrm{F}$ during working hours and not more than $55^{\circ} \mathrm{F}$ during non-working hours for the heating season, and at not lower than $80^{\circ} \mathrm{F}$ for the following season. ${ }^{1}$

- Reducing the use of automotive fuels by 10 percent.

\section{Roles of Department of Energy and Other Federal Agencies}

The Department of Energy is charged with coordinating national energy policy by performing in a policymaking, regulatory, and informational role, as well as conducting research and development on more effective use of existing energy sources. Within the Federal Government the Department of Energy is charged with coordinating and promoting energy conservation and is responsible for Federal energy

\footnotetext{
1 The thermostat directive was superceded on July 15 1979, by the Emergency Building Temperature Restrictions that applied to most nonresidential private and public buildings. These restrictions are similar, but allow temperatures of $78^{\circ}$ during the cooling season. The restrictions remain in force until April 15, 1980, unless recinded earlier by the President.
} 
management policies, procedures, and reporting. The agencies participating in FEMP are given financial and programmatic flexibility to meet Federal energy conservation goals within the context of their assigned missions. Responsibility for planning, scheduling, budgeting, and selecting cost-effective energy conservation projects rests with the individual agencies. Goals for reducing energy use associated with general operations are developed by each agency and approved by DOE.

\section{Life Cycle Costing}

DOE, with the help of the National Bureau of Standards and other Federal agencies, has developed a methodology and procedure for life cycle cost (LCC) analyses of Federal buildings. This methodology is to be used by the Federal agencies in evaluating energy conservation measures, including solar energy systems for new and existing buildings. This evaluation method takes into account relevant costs over time of a building's design, system components, materials, and operations which can affect a building's energy use and operating costs. Life cyolc costing is a tool particularly suited for determining which energy conservation projects are cost effective and for setting projects into priority order for the highest net return on the Federal energy conservation budget. The methodology was published as a proposed rule making announcement in the Federal Register on April 30, 1979. Following a public comment period, the proposed rule is now being revised in response to some of the comments. A notice of final rulemaking will be published in the near future.

\section{Coordination of Program Activities}

The coordination of these various programs, directives, and their associated activities is accomplished primarily through an Interagency Federal Energy Policy Committee known as the "656 Committee". This committee consists of 10 assistant administrators and assistant secretaries of designated agencies. Headed by the Under Secretary of DOE, the committee was established in accordance with Section 656 of the Department of Energy Organization Act (Public Law 95-91). The 656 Committee meets to provide policy guidance and to review agency progress and Federal energy conservation plans and associated investments. The purpose of the committee is to strengthen energy conservation programs which emphasize productivity through energy efficiencies and to encourage interagency cooperation in energy conservation. The committee will be used to coordinate Federal efforts to achieve a replication of the Federal energy management experience in the public sector. The agency membership in this committee and the conservation officers designated by their respective agency heads as committee members are listed in Appendix C.

\section{Federal Conservation}

Energy savings before 1975 were achieved with minimal investment through relatively sim. ple energy conservation actions. These actions included reducing aircraft and ship operating hours, lowering vehicle mileage, adjusting thermostats, and turning off lights. Although simple and inexpensive, these actions were highly effective. Because these steps had, for the most part, already been taken by FY 1975, the Federal Government was at a major "crossroads" in its energy management program. Although substantial energy savings had been achieved at little cost, additional energy savings were known to be possible through investment in more sophisticated energy conservation measures. Further energy savings were, and still are, necessary because recent events and escalating energy prices have made it clear that abundant supplies of cheap energy can no longer be assured.

\section{Impact of Federal Conservation on the Public Sector}

It is readily apparent that Federal efforts to conserve energy have a positive impact upon other sectors of the nation. Federal actions influence the nation in several ways:

- As a major buyer of goods and services, the Federal Government is able to support 
and encourage efforts by contractors and other suppliers to conserve energy;

- Through the purchase of energy related services, devices, and the procurement of vehicles and equipment which meet energy efficient standards, the Federal Government encourages the development of industries that offer energy conserving goods and services;

- Through its adherence to energy efficient standards in the design and construction of new buildings and associated heating, ventilating, and air conditioning equipment, the Federal Government encourages architects, equipment suppliers, and build. ing contractors to promote energy conservation in future projects, both Federal and non-Federal;

- As a massive energy consumer and manager, the Federal Government can demonstrate to the nation that greater productivity can be obtained through energyefficient technologies;

- By demonstrating selected energy conser. vation systems, products, and programs the Federal Government will become a showcase of cost-effective conservation and a proving ground for testing technical and administrative concepts.

\section{Organization of the Report}

The following sections of this report provide specific information on the energy conservation programs and achievements of the Federal Government during FY 1978. In Chapter II an overview of energy use in the government is presented, the Federal Energy Management Program is outlined, and an analysis of major energy using agencies is provided. Specific sections are devoted to energy conservation in General Operations, Buildings, and in related Programs. The section on Future Activities presented in Chapter III assesses program strengths and weaknesses, and recommends changes in direction and thrust. Appendix A, Program Highlights, presents examples of some of the many innovative and successful programs that have contributed to Federal energy use reductions in FY 1978. Other relevant information is presented in Appendices $B$ through $F$. 


\section{FEDERAL ENERGY MANAGEMENT PROGRAM THE FEDERAL ENERGY PICTURE}

The Federal Government is the single largest user of energy in the nation, using 2.2 percent of the total energy consumed by the United States in FY 1978. This is more energy than was used by the five largest private users of energy combined-U.S. Steel, Union Carbide, Gulf Oil, International Paper, and General Motors Corp. oration. The large amount of energy used within the government is consumed by almost six million people, in more than 490,000 buildings, in the operation of some 106,000 automobiles, and in support of more than 400,000 tactical and mission related vehicles, ships, aircraft, and other equipment.

Federal energy consumption is composed of the six basic categories shown in Figure 2-1. This figure illustrates the percentages of the various fuels that were used in FY 1975 and the changes in the percentage use of these fuels in FY 1978.

The key statistics related to Federal energy use for fiscal years 1975 through 1978 are summarized in Table 2-1. Individual agency results are presented for the 18 largest energy users, while results for the eight other large energy using agencies within the FEMP program are combined and listed in the table as "Others." Energy consumed by the remaining agencies is incorporated within the General Services Administration's statistics.

The 10 largest energy using agencies account for 98 percent of the energy used by the Federal Government. These agencies are listed below according to descending magnitude of energy consumed.

Based on the information illustrated in Figure 2-1 and tabulated in Table 2-1, a number of important findings emerge:

- Federal energy consumption was reduced $5.9 \%$ between 1975 and 1978.

- Cumulative energy use avoidance since FY 1975 totals approximately 31 MBOE.

- $79 \%$ of the total conservation achieved during the period is attributable to general operations (vehicles and equipment), while

$21 \%$ of the savings is a result of conser. vation in buildings and facilities.

- Energy used in general operations was reduced $9.3 \%$, largely as a result of the reduction in the use of jet fuel by the Department of Defense.

- Energy consumption in buildings and facilities was reduced $2.5 \%$ through decreases in the use of natural gas and coal.

- 10 of the 18 largest agencies did not reduce their overall energy consumption in 1978 based on the level of consumption in 1975.

It is important to bear in mind that failure to achieve greater reductions in total energy use does not, by itself, indicate lack of emphasis on energy conservation or failure to comply with legislative mandates and executive orders. The goals of the FEMP program are keyed to greater productivity through efficiencies in energy use.

Agency

Department of Defense

Department of Energy

\section{U.S. Postal Service}

General Services Administration

Veterans Administration

Department of Transportation

National Aeronautics and Space Administration

Department of the Interior

Department of Agriculture

Department of Health, Education, and Welfare
Percentage of Total

FY 1978

Energy Use

80.4 percent

5.0 percent

3.2 percent

2.6 percent

2.3 percent

1.6 percent

1.3 percent

0.7 percent .

0.6 percent

0.5 percent

98.0 percent 


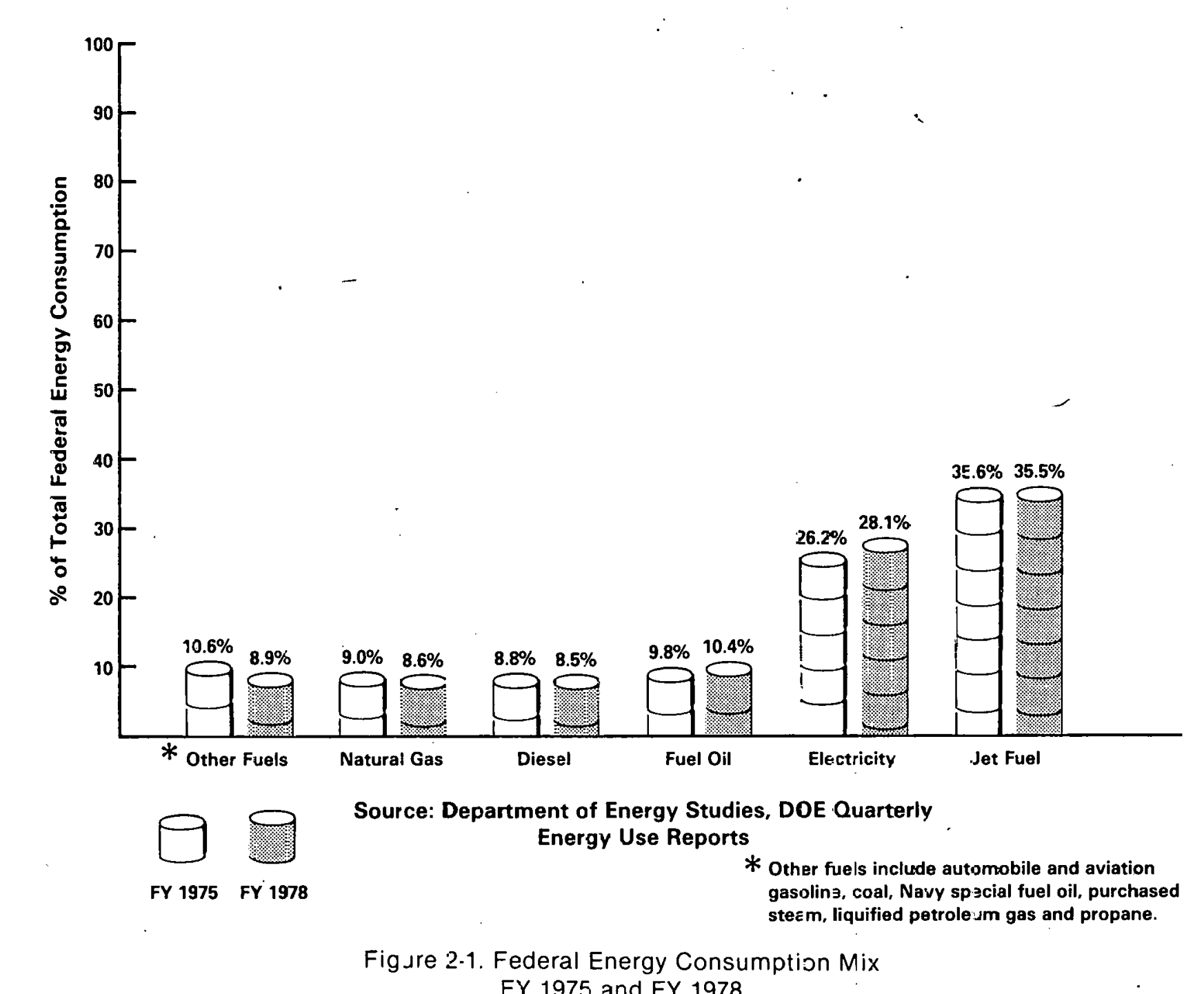


TABLE 2.1. Federal Government Energy Use FY 1975 to FY 1978

Energy Use in Billions (Btu $\times 10^{9}$ ) of Btu and Million Barrels of Oil Equivalent (MBOE)'

\begin{tabular}{|c|c|c|c|c|c|c|c|c|c|c|c|c|}
\hline \multirow{2}{*}{$\begin{array}{l}\sigma \\
\text { Agency }\end{array}$} & \multicolumn{3}{|c|}{ FY 1975} & \multicolumn{3}{|c|}{ FY 1976} & \multicolumn{3}{|c|}{ FY 1977} & \multicolumn{3}{|c|}{ FY 1978} \\
\hline & $\begin{array}{l}\text { Buildings } \\
\text { and } \\
\text { Facilities }\end{array}$ & $\begin{array}{c}\text { General } \\
\text { Operations }\end{array}$ & $\begin{array}{c}\text { Total } \\
\text { Btu } \times 10^{9}\end{array}$ & $\begin{array}{l}\text { Buildings } \\
\text { and } \\
\text { Facilities }\end{array}$ & $\begin{array}{c}\text { General } \\
\text { operations }\end{array}$ & $\begin{array}{c}\text { Total } \\
\text { 3tu } \times 10^{9}\end{array}$ & $\begin{array}{l}\text { Buildings } \\
\text { and } \\
\text { Facilities }\end{array}$ & $\begin{array}{c}\text { General } \\
\text { Operations }\end{array}$ & $\begin{array}{c}\text { Total } \\
\text { Btu } \times 10^{9}\end{array}$ & $\begin{array}{l}\text { Buildings } \\
\text { and } \\
\text { Facilities }\end{array}$ & $\begin{array}{c}\text { General } \\
\text { operations }\end{array}$ & $\begin{array}{c}\text { Total } \\
\text { Btu } \times 10^{9}\end{array}$ \\
\hline DOD & $608,758.9$ & $857,947.2$ & $1,466,706.1$ & $597,556.1$ & $833,751.6$ & $1,431,307.7$ & $601,957.5$ & $825,675.9$ & $1,427,633.4$ & $592,299.7$ & 770.517 .7 & $1,362,746.7$ \\
\hline DOE & $84,914.3$ & $1,901.8$ & $86,816.1$ & $85,424.7$ & $1,779.8$ & $87,204.5$ & $83,990.2$ & $1,850.9$ & $85,841.1$ & $84,591.7$ & $2,439.5$ & $87,031.2$ \\
\hline USPS & $44,269.0$ & $11,241.0$ & $55,510.0$ & $43,701.8$ & $11,316.4$ & $55,018.2$ & $47,20 \div .5$ & $11,739.5$ & $58,941.0$ & $43,395.2$ & $11,517.6$ & $54,912.8$ \\
\hline GSA & $44,684.6$ & 184.1 & $44,868.7$ & $43,661.3$ & 175.0 & $43,836.3$ & $43,609.5$ & 176.0 & $43,785.5$ & $44,453.1$ & 169.8 & $44,622.9$ \\
\hline VA & $38,586.7$ & 620.8 & $39,207.5$ & $35,834.3$ & 633.0 & $36,467.3$ & $37,311.0$ & 614.0 & $37,925.0$ & $38,834.7$ & 610.2 & $39,444.9$ \\
\hline DOT & $15,781.2$ & $11,053.3$ & $26,834.5$ & $14,797.5$ & $12,215.6$ & $27,013.1$ & $15,881.4$ & $12,433.9$ & $28,315.4$ & $15,905.2$ & $12,526.1$ & $28,431.3$ \\
\hline NASA & $25,546.9$ & $1,697.9$ & $27,244.8$ & $24,245.5$ & $1,620.7$ & $25,866.2$ & $22,349.8$ & $1,730.2$ & $24,080.0$ & $20,771.0$ & $1,708.5$ & $22,479.5$ \\
\hline DOI & $9,195.2$ & $3,254.6$ & $12,449.8$ & $11,054.3$ & $3,854.8$ & $14,909.1$ & $11,559.2$ & $3,659.9$ & $15,219.2$ & $9,087.5$ & $3,339.4$ & $12,426.9$ \\
\hline Agriculture & $6,755.7$ & $5,173.1$ & $11,928.8$ & $6,056.1$ & $5,550.6$ & $11,606.7$ & $5,477.2$ & $5,295.5$ & $10,722.8$ & $5,457.6$ & $5,765.2$ & $11,222.8$ \\
\hline HEW & $8,521.1$ & 738.4 & $9,259.5$ & $8,818.5$ & 771.6 & $9,590.1$ & $9,228.8$ & 688.5 & $9,917.3$ & $8,782.0$ & 657.2 & $9,439.2$ \\
\hline Justice & $4,834.0$ & $1,855.7$ & $6,689.7$ & $4,976.3$ & $2,195.8$ & $7,172.1$ & $5,359.6$ & $1,999.7$ & $7,359.3$ & $5,208.2$ & $1,959.1$ & $7,167.3$ \\
\hline Treasury & $2,023.5$ & $2,215.2$ & $4,238.7$ & $1,959.8$ & $2,224.9$ & $4,148.7$ & $2,023.5$ & $2,235.7$ & $4,268.5$ & $2,088.3$ & $2,234.0$ & $4,322.3$ \\
\hline Commerce & $2,385.7$ & $1,130.0$ & $3,515.7$ & $2,448.7$ & $1,420.4$ & $3,869.1$ & $2,435.2$ & $1,395.7$ & $3,830.9$ & $2,433.8$ & $1,348.6$ & $3,792.4$ \\
\hline Panama Canal & $1,396.3$ & $1,308.8$ & $2,705.1$ & $1,355.7$ & $1,173.0$ & $2,528.7$ & $1,364.4$ & $1,261.6$ & $2,626.0$ & $1,323.3$ & $1,193.1$ & $2,516.4$ \\
\hline Labor & $1,326.4$ & 251.9 & $1,578.3$ & $1,344.0$ & 287.8 & $1,631.8$ & $1,460.5$ & 297.2 & $1,757.7$ & $1,395.0$ & 376.2 & $1,771.2$ \\
\hline TVA & 253.9 & 510.4 & 764.3 & 348.0 & 552.8 & 900.8 & 603.1 & 548.2 & $1,151.3$ & 479.1 & 602.1 & $1,081.2$ \\
\hline EPA & 426.8 & 133.0 & 559.8 & 448.1 & 116.0 & 564.1 & 438.0 & 119.4 & 557.4 & 473.8 & 121.6 & 595.4 \\
\hline HUD & 0.0 & 375.0 & 375.0 & 0.0 & 308.1 & 308.1 & 0.0 & 315.5 & 315.5 & 0.0 & 336.5 & 336.5 \\
\hline Others ${ }^{2}$ & 317.9 & 296.7 & 614.6 & 26.8 & 252.0 & 278.8 & 29.1 & 258.9 & 288.0 & 436.2 & . 336.1 & 772.1 \\
\hline Total Btu $\times 10^{9}$ & $899,978.1$ & $901,888.9$ & $1,801,867.0$ & $884,057.5$ & $880,199.9$ & $1,764,257.4$ & $892,279.5$ & $872,296.2$ & $1,764,535.3$ & $877,354.7$ & $817,758.4$ & $1,695,113.1$ \\
\hline MBOE & 155.2 & 155.4 & 310.7 & 152.4 & 151.8 & 304.2 & 153.8 & 150.4 & 304.2 & 151.3 & 140.9 & 292.3 \\
\hline \multirow{3}{*}{\multicolumn{4}{|c|}{ Annual Savirigs From Fy 1975}} & & & & & & & & & \\
\hline & & & & $15,920.6$ & $2,168.9$ & $37,609.6$ & $7,699.0$ & $29,592.7$ & $37,331.7$ & $22,623.4$ & $84,130.5$ & $106,753.9$ \\
\hline & & & & 2.7 & - 3.7 & 6.5 & 1.3 & 5.1 & 6.4 & 3.9 & 14.5 & 18.4 \\
\hline \multirow{2}{*}{\multicolumn{4}{|c|}{ Cumulative Savings From FY 1975}} & & & & & & & & & \\
\hline Btu $\times 10^{9}$ & & & & $15,920.6$ & $2,168.9$ & $37,609.6$ & $23,619.6$ & $51,281.7$ & $74,941.3$ & $46,243.0$ & $135,412.2$ & $181,695.2$ \\
\hline MBOE & & & & 2.7 & 3.7 & 6.5 & 4.0 & 8.8 & 12.9 & 7.9 & 23.3 & 31.3 \\
\hline
\end{tabular}

Footnotes on following pages are an integral part of this table. 


\section{FOOTNOTES}

1. The figures in this table differ from some figures in the FY 1977 Federal Energy Management Report; that Report showed 1,704.57 trillion Btus consumed in FY 1975 by all agencies. The reasons for the differences are:

In last year's report, DOD's total energy use was given as 1,307.77 trillion Btu in FY 1975: The FY 1978 Report reflects the addition by DOD of building energy use outside the United States. Adjustments between categories resulting from more accurate reporting are present each year from FY 1975 through FY 1977.

DOE total energy use in FY 1975 was given as 83.63 trillion Btu in the 1977 report. The FY 1978 Report includes the energy used in programs transferred to DOE from DOI for FY 1975 and FY 1978. Revisions to FY 1976 and FY 1977 data have not been completed. However, the FY 1977 total is estimated to be 88.82 trillion Btu.

DOI total energy use in FY 1975 was given as 14.78 trillion Btu. The FY 1978 Report reflects adjustments of $F Y 1975$ and $F Y 1978$ energy use resulting from mission responsibilities transferred to DOE. Revisions to FY 1976 and FY 1977 data have not been completed.

Additional minor differences from agency data proscnted in the FY 1977 Federal Energy Management Program Report are due to rounding to trillion Btu inthe $\Gamma Y 1977$ Rejull arld audit adjustments associated with more accurate reporting. Columns may not add due to rounding.

2. "Other" agencies include Small Business Administration Office of Personnel Management, Civil Aeronautics Board, Federal Communications Commission, Department of State, Interstate Commerce Commission and Office of Management and Budget. The FY 1978 Report reflects National Science Foundation data for FY 1975 and FY 1978. NSF data have not been added to the FY 1976 and FY 1977 reports. 
Thus, while an agency's energy use in buildings might increase in absolute terms, energy use per gross square foot could in fact be much lower due to increases in the size of its buildings' inventory. The same is true of energy use in operations, where mission changes could result in higher fuel requirements. Finally, the energy use data in this table has not been adjusted to account for climatic factors which can cause significant variations in requirements from one year to the next.

Major mission changes or building inventory changes were reported by many agencies experiencing increased energy use in FY 1978 (as compared to the FY 1975 base year). These changes were not verified by DOE; similarly their significance has not been assessed. They are, however, reported in Appendix B.

\section{PROGRAM STRUCTURE}

The Federal Energy Management Program (FEMP) is intended to assure an effective and timely response to the Federal Government's need to manage and control its use of energy. The program is being structured around a common set of management goals to assure a coordinated approach to policy and program devel. opment. The program is also developing a common system of data recording and reporting, and an effective exchange of information among agencies and the public sector. Progress is being made in this regard, but more remains to be done.

The Department of Energy is charged with coordinating and promoting the program and is responsible for reporting progress. The participating agencies are given specific planning methodologies. At the same time, they are also given financial and programmatic flexibility to meet their energy conservation goals and objectives within the context of their assigned missions. Responsibility for planning, scheduling, budgeting, and the selection of costeffective energy conservation measures rests with the agencies. In addition, the Office of Management and Budget has responsibility for receiving and making recommendations to the President about agency budget proposals. A number of mechanisms have been developed to assure achievement of the FEMP management goals:

- The major energy using agencies designated energy conservation coordinators, while small energy using agencies have assigned personnel to handle energy conservation matters. The energy conservation coordinators meet several times each year to discuss programs, exchange information, and determine policy directions.

- The 26 major energy using agencies prepare and submit quarterly reports to the Department of Energy. These reports are aggregated and summarized and provide information on total fuel use by fuel type and category of operation. The more complete reports are prepared and submitted annually in response to the requirements of Executive Order 12003.

- Agencies are required to prepare energy conservation plans for their General Operations and Buildings Programs. Agency plans will eventually be reviewed and approved by the Department of Energy.

- Those agencies that own and operate buildings are conducting preliminary energy audits to gather statistical data on building size, category, energy use, and major energy using systems within those buildings.

- Agencies that own and operate vehicles have established or are in the process of developing energy conservation plans to reduce the use of automobile gasoline where mission responsibilities permit. They are also attempting to meet the fuel efficiency goals of Executive Order 12003 as the basis for establishing further detailed study priorities.

- When substantial investment is required for energy saving projects, agencies are preparing long range investment plans. These investment plans will be analyzed and evaluated by standard criteria developed by DOE. Publication of a life cycle cost analysis methodology by DOE will help establish consistent priorities for agencies' projects.

Not all of the above mechanisms have been vigorously implemented by DOE and par- 
ticipating agencies. Moreover, some are behind the deadline mandated in legislation.

The management and control of energy use within the Federal Government is divided into two broad program areas: the General Opera. tions Program and the Buildings Program. The Buildings Program is concerned with reducing energy used to heat, cool, ventilate and light Federal buildings. The General Operation Program involves reducing agency energy use other than in buildings, including travel, tactical operations, research experiments, and the like. The General Operations Program is also concerned with energy used for process operations within buildings. These two programs will form the basis for the anticipated replication of the Federal energy management experience in the public sector. In addition to these programs, the Federal Energy Mangement Program is involved in the promotion and coordination of such specific conservation-related activities as: recycling waste paper, promoting car pools and van pools, and creating greater energy awareness among Federal employees.

\section{ENERGY MANAGEMENT IN BUILDINGS \\ Overview}

The Federal Government used 2.5 percent less energy in buildings during FY 1978 than during the FY 1975 base year. This is equivalent to 3.9 million barrels of oil equivalent, or over 22.6 trillion Btu. Of this 2.5 percent reduction, 1.8 percent is attributable to reductions by the Department of Defense. Most of these reductions were actually achieved in FY 1978.

In July of 1977, Executive Order 12003 man. dated energy use reduction goals of 20 percent and 45 percent in average annual energy use per gross square foot of floor area for existing and new Federal buildings, respectively. The President has required that these reductions occur by 1985 . If the 20 percent goal is achieved, it would mean a reduction in the energy used annually in existing buildings from $155 \mathrm{MBOE}$ in FY 1975 to 124 MBOE in FY 1985 (assuming a constant inventory). This projected reduction of
31 MBOE in annual consumption by 1985 would free enough energy to meet the winter heating requirements for 1.2 million homes each year. Energy diverted from Federal use is expected to be even greater as new buildings, meeting the 45 percent reduction standard, enter the inventory. The present replacement rate is about one-half percent per year.

\section{Federal Government Building Inventory}

Twenty-seven agencies of the Federal Government own approximately 3.1 billion square feet of floor space in more than 490,000 buildings worldwide. The Department of Defense is the largest building owner with 395,000 build. ings, totaling more than 2.4 billion square feet of floor space. Other agencles own about 95,400 buildings totaling 756 million square feet of floor space. These buildings use differing amounts of energy.

Agencies that do not own buildings, lease space directly from GSA or private sources, or are tenants in buildings leased by other agencles. The Federal Government currently leases about 238 million square feet of floor space in 59,000 buildings worldwide.

Slx governmént agencies account for 94 percent of all energy used in Federal buildings. 'The relative departments' shares of building energy use is as follows:

\begin{tabular}{lrr}
\multicolumn{1}{c}{ Agency } & & Energy Use \\
\cline { 1 - 1 } Department of Defense & & $67.5 \%$ \\
Department of Energy & & $9.6 \%$ \\
General Services Administration & & $5.1 \%$ \\
U.S. Postal Service & & $4.9 \%$ \\
Veterans Administration & & $4.4 \%$ \\
National Aeronautics and & & \\
$\quad$ Space Administration & & $2.4 \%$ \\
\hline & & $93.9 \%$
\end{tabular}




\section{Federal Buildings' Fuel Mix}

The various types of fuels used in Federal Buildings include electricity, fuel oil, natural gas, coal, and a small percentage of other fuels, such as purchased steam, diesel oil, and propane. This "fuel mix" changes as agencies switch fuels, curtail their use of natural gas, or simply change the amounts of these fuels that they use. Table 2-2 provides a comparison between the fuel mix in Federal buildings for $F Y$ 1975 and FY 1978. The trends indicated are:

- An increase in the percentage and absolute amount of electricity used;

- An increase in the percentage and absolute amount of fuel oil used;

- A decrease in the percentage and absolute amount of natural gas used; and
- A decrease in the percentage and absolute amount of coal used.

One of the objectives of the Federal Energy Management Program has been to accomplish the changeover from the more expensive and scarce imported fuels to the greater use of coal, which is more abundant in the United States. To date this has not been accomplished. The high percentage of electricity used in buildings reflects the significant loads from lighting, air conditioning, pumps, fans, and related electrically-driven equipment. The increased use of electricity and concurrent declines in other major boiler fuels between $F Y$ 1975 and FY 1978 may indicate a possible trend toward electrically driven air-conditioning and away from steam-absorption air conditioning and a possible trend toward electric heat pumps. Information is not available to substantiate whether this is actually the case.

\section{TABLE 2:2. Major Fuel Types Used in Federal Buildings \\ (FY 1975 and FY 1978)}

\begin{tabular}{|c|c|c|c|c|c|c|}
\hline \multirow[b]{4}{*}{ Buildings \& Facilities } & \multicolumn{6}{|c|}{ Fuel Mix } \\
\hline & \multicolumn{3}{|c|}{ FY 1975} & \multicolumn{3}{|c|}{ FY 1978} \\
\hline & \multirow[b]{2}{*}{ Btu $\times 10^{9}$} & \multicolumn{2}{|c|}{ Percent of: } & \multirow[b]{2}{*}{ Btu $\times 10^{9}$} & \multicolumn{2}{|c|}{ Percent of: } \\
\hline & & B\&F & Total & & B\&F & Total \\
\hline Electricity & $470,871.1$ & 52.3 & 26.2 & $476,682.1$ & 54.3 & 28.1 \\
\hline Fuel Oil & $176,436.2$ & 19.6 & 9.8 & $177,073.9$ & 20.2 & 10.4 \\
\hline Natural Gas & $163,010.3$ & 13.1 & 9.0 & $144,852.4$ & 16.5 & 8.6 \\
\hline Coal & $77,187.5$ & 8.6 & 4.3 & $67,024.4$ & 7.6 & 4.0 \\
\hline Purchased Steam & $6,937.9$ & 0.8 & 0.4 & $7,705.5$ & 0.9 & 0.4 \\
\hline LPG & $5,535.4$ & 0.6 & 0.3 & $4,016.4$ & 0.5 & 0.2 \\
\hline B\&F Subtotal & $899,978.1$ & 100.0 & 50,0 & $877,354.7$ & 100.0 & 51.7 \\
\hline
\end{tabular}

Source: Department of Energy, Quarterly Energy Use Reports 


\section{Planning and Programming for Federal Buildings}

All agencies owning buildings are required by Executive Order 12003 to prepare 10-year plans establishing, to the maximum extent practicable, the methods that will be employed to meet the energy conservation goals for existing and new Federal buildings. These 10-year plans are to be prepared based on planning guidelines to be issued by the Department of Energy.

- Goals-These are the 20 and 45 percent Btu per gross square foot energy reduction goals for Federally owned buildings that are set forth in the executive order. In addition, goals are established for the installation of renewable energy systems, and for the achievement of a 30 percent reduction in the use of petroleum based fuels in Federal buildings by 1985 . Specific goals have not been established for leased Federal buildings, and such goals will be established by individual agencies.

- Pre-existing Plans-In anticipation of the issuance of the guidelines, a number of agencies have already developed plans and programs for the reduction of building energy use and have achieved savings as a result. The guidelines will propose that pre-existing plans and program be integrated with the 10-year plans.

- Technical Surveys-Technical surveys are used to identify appropriate changes in operation and maintenance procedure, cost effective alternatives for retrofitting building systems, as well as the capital cost and energy cost savings likely to result. Most agencies have already conducted such surveys. The proposed guidelines provide information regarding the conduct of technical surveys and the data to be gathered.

- Retrofit Program-The objective of the retrofit program is to replace existing building systems with life cycle cost effective alternative building systems in order to achieve the 20 percent energy use reduction goal for existing Federally owned buildings, and the goal for leased buildings that will be established by individual agencies. The guidelines call for details on agency retrofit programs and application of rigorous cost effectiveness measures.

- Design Program for New Federal Buildings -The greatest opportunities for conserving building energy will exist in new buildings, and the guidelines will call for each agency to include plans to achieve the required 45 percent energy use reduction goal.

- Other Conditions of Operation-This section of the guidelines discusses lighting efficiency standards, thermal efficiency standards and insulation requirements, restrictions on building hours of operation, thermostat controls, and other conditions of operation.

Following publication of the final guidelines, it is anticipaled that agency 10 -year buildings plans will be prepared to conform to the stated requirements, thus assuring a common basis for all such plans within the Federal Government.

The plans that have been prepared by various agencies in advance of the issuance of the DOE guidelines, generally address new and existing buildings and leased buildings. In the existing buildings' sections of these agency plans, the agencies may address conservation actions such as:

- Energy audits and surveys,

- Retrofit programs, using life cycle costing criteria, and

- Operations and maintenance modifications.

In new buildings' sections of these plans, the following types of conservation actions may be addressed:

- Development of energy-efficient design standards,

- Evaluation of alternative fuel sources, par. ticularly solar and other renewable fuels,

- The use of computer simulation methods in the design process, and

- Rigorous application of life cycle cost and energy efficiency criteria.

Finally, in connection with leased buildings, agencies may indicate the following types of actions: 
- Review of existing lease agreements, and

- Revision of procurement standards.

Annual program goals are stated in some agencies' plans. In some cases, these goals exceed the requirements of the executive order. For example, the U.S. Postal Service has established a minimum long range goal to reduce energy use per gross square foot in its existing buildings by 20 percent. In addition to this, the Postmaster General has ordered an additional five percent reduction in all energy use. In other cases, agency goals fall short of the requirements of the executive order.

Some agency goals are not presently stated in terms of reducing average annual energy use on a per gross square foot basis as required by the executive order. Moreover, few of the 18 major energy using agencies reported a figure for energy use per gross square foot. Of those agencies reporting such a figure, data problems were of so great a magnitude as to preclude placing any confidence in the reported value.

As an example, total building energy use may have been divided by floor space in buildings owned but not in those leased. The total building energy use figure very likely included energy used in leased bulldings for which the agen. cy was paying the bill. Thus, the average annual energy use per gross square foot figure resulting from such a division would be inaccurate.

Repeated attempts were made during the preparation of this report to arrive at reasonable estimates of average annual energy use per gross square foot for the 18 major energy using agencies. The magnitude of the data problems was so great that each attempt failed to yield a set of numbers in which confidence could be placed. Based on past measurement attempts, the conclusion to be drawn is that a consistent, accurate set of average annual energy use per gross square foot for the 18 major energy using agencies is not available until consistent reporting mechanisms are established.

Some form of reporting and data collection system is presently used by each agency to measure progress toward its goals. Typical of the data that may be gathered are:

\section{Energy Data:}

- Energy use by building category
- Energy use by fuel type

- Fuel costs.

Buildings Data:

- Numbers of buildings by category

- Gross square footage of buildings by category.

Program Data:

- Program costs

- Energy use avoidance resulting from the program

- Program cost savings through avoidance of energy use.

Lack of central guidance and direction has resulted in procedures, systems, and reporting formats that vary from agency to agency, making cohesive management and decision making difficult, if not impossible. This situation is expected to be corrected when DOE published Buildings and General Operations Guidelines.

\section{Energy Conservation Investment Programs}

Despite the lack of guidelines, agencies are programming resources and budgeting funds to accomplish energy conservation projects in buildings. For example, the General Services Administration plans to spend $\$ 205$ million by FY 1986 to conserve energy use in its existing buildings. To date, the GSA has expended a total of $\$ 10.8$ million and has achieved a total energy use reduction of 1.2 trillion Btu and a cost avoidance of $\$ 6.7$ million. Typically, retrofit investment programs have received the greatest emphasis and have shown the ability to achieve payback periods of less than five years on program funds invested.

The Department of Defense's Energy Conservation Investment Program (ECIP) began in FY 1976. The 1.5 billion dollar, multi-year program is the principal source of funds for retrofit projects to achieve energy use reduction at installations and to improve routine operation and maintenance programs of the facilities: Since the ECIP's inception, energy conservation retrofit projects at existing DOD facilities have significantly reduced the amount of energy re- 
quired to heat, cool, and provide industrial support to DOD installations.

\section{Existing Buildings Program Area}

The primary target for energy conservation has been the government's inventory of existing buildings. The vast majority of energy use reductions for Federal buildings by 1985 will be attributable either to modifications in building operations and maintenance or to retrofit of electrical, mechanical, and structural systems. A small portion will be contributed by the growing inventory of new, more energy efficient buildings.

The following approach is being used by many agencies to conduct programs for the reduction of energy use in existing buildings:

- Establish an energy use baseline to facilitate measurement of progrcos toward the goal of 20 percent reduction in average annual energy use per gross square foot of floor area by 1985. (Not all agency goals are expressed in energy use per gross foot; some goals are in terms of total energy use.)

- Conduct preliminary energy audits to develop buildings data by size, category, energy use, and energy using systems.

- Perform energy surveys to identify energy conservation options for operation, maintenance, and retrofit of specific existing buildings.

- Prepare investment plans and schedules to meet the identified goals.

- Continue existing energy investment programs.

- Perform analyses of the feasibility of conversion to solar energy or other renewable fuel sources.

- Review and evaluate agreements for leased buildings.

Reports indicate that several agencies have completed the preliminary energy audit phase on larger buildings and are into the detailed survey phase on some of these buildings.

A major initiative to monitor and control the use of energy in buildings is being conducted by Federal agencies, including Department of
Defense, U.S. Postal Service, Veterans Administration, National Aeronautical and Space Administration, and General Services Administration. This effort is being accomplished through the installation of various electrical, electro-mechanical, and electronic devices. These devices may be as simple as electrical meters to measure energy consumption in individual facility units or time clocks to automatically turn on or shut down mechanical systems. Complex systems often include programmable computers or microprocessors and control systems that can automatically:

- Monitor and record building energy use and environmental conditions,

- Process and summarize data received from field sensors in the respective building areas for management review,

- Conntrol the environmental conditions in these areas and thus control building energy use.

The benefits of increased automatic monitor. ing and control include:

- Precision matching of energy use and loads;

- Optimal use of available energy;

- Load shedding to reduce peak energy con. sumption to avoid penalty costs;

- Simplified performance analysis, progress reporting, and accountability;

- Automatir trouble indication and maintenançe monitoring;

- Feedback for behavior modification programs; and

- Combination with existing security and fire protection and warning systems.

\section{Buildings Energy Use Avoidance}

In FY 1978, the Federal Government used 2.5 percent less energy in buildings than during $F Y$ 1975. This represents a reduction in energy used in buildings by $3.9 \mathrm{MBOE}$ in FY 1978 as compared to $F Y$ 1975. The cumulative energy use avoidance between FY 1975 and FY 1978 is about 8 MBOE. Only two agencies, GSA and NASA, appear to have sustained continuous downward trends in buildings energy use be. 
tween FY 1975 and FY 1978. Moreover, eight of the 18 largest energy using agencies showed higher total energy use in buildings during $F Y$ 1978 than during FY 1975. However, the agencies showing higher energy use only accounted for 8.6 percent of the total buildings energy use in FY 1978.

The President's goal is to achieve a 20 percent annual energy reduction per square foot in buildings between FY 1975 and FY 1985. The 2.5 percent reduction in energy used for Federal buildings achieved in the third year of this program indicates that a much greater commitment to energy conservation in Federal buildings will be necessary to influence the present trend in order to achieve greater energy use avoidance.

\section{New Buildings Program Area}

To meet the goal of a 45 percent reduction in average annual energy use per gross square foot of floor space by FY 1985 as compared to FY. 1975, Federal agencies are engaged in programs for:

- Development and promulgation of new design standards and energy budgets for new buildings;

- Fuel source analysis and alternate energy systems evaluations in building design contracts;

- Development and utilization of computer simulation programs to model building thermal loads and energy systems performance;

- Employment of life cycle costing techniques and criteria in the making of decisions relative to building design options;

- Extensive participation in and sponsorship of energy technology demonstration projects to gain experience in the application of these technologies;

- Installation of energy monitoring and control systems and other devices to monitor and optimize energy use;

- Review and development of agency design, construction and material specifications, policies and requirements for new building design and construction; and
- Establishment of new procurement standards for leased buildings.

DOD has undertaken an extensive revision of its construction criteria manual and has estab. lished energy budgets for various categories of buildings. The Department intends to continue the collection of design data to establish a realistic data base for the refinement of final criteria.

The initial impact of adopting building energy budgets and of thermal and lighting system design standards is expected to result in an increase in design and construction costs by as much as five percent. Cost savings due to reduced energy use, however, can be expected to amortize the additional initial investment cost over a period of three to five years. In cases where alternative energy systems such as solar are incorporated into a building design, the payback period may be 10 to 30 years. The additional benefits to be realized from the reduced use of nonrenewable fossil fuels, however, will be significant in terms of national self-sufficiency goals.

\section{Non-Critical and Renewable Energy Sources for Buildings}

While reduction in the direct use of natural gas for buildings and facilities operations has been achieved, the use of fuel oil has increased. It is expected that the Federal Government's energy conservation efforts will focus on the conservation of these fossil fuels. In addition the use of more plentiful energy sources such as coal, or renewable sources of energy should be stressed more heavily. Some Federal agencies are taking initiatives to evaluate renewable energy sources and to incorporate systems which use these sources into new and existing buildings. Solar and geothermal sources are ex. pected to be viable alternatives.

Use of renewable building energy sources by Federal agencies is being promoted through:

- Requirements for energy source analyses or, as a minimum, alternate energy system evaluations in design contracts;

- Participation in DOE-sponsored demonstration programs; 
- Sponsorship of engineering development efforts to tailor new technologies to specific agency requirements;

- Revision of conservation policies and requirements to allow expanded consideration of alternate energy systems.

Symbolic of Federal efforts to reduce consumption of nonrenewable resources is the retrofit of the West Wing of the White House to incorporate a solar domestic hot water supply system. Thermal energy derived from this solar system is expected to displace 75 percent of the conventional energy required to provide for the hot water needs of this part of the building.

Many agencies have undertaken solar energy demonstration projects. These agencies include: The Department of Justice, the Department of Defense, the Department of the InterIor, the General Services Administration, and the U.S. Postal Service. The projects have included the application of solar energy to the heating and cooling of buildings, the powering of remote radio transmitters, marker buoys, and livestock fencing. The U.S. Navy reports their program goal is to achieve an 11 percent substitution of shore energy usage with power derived from alternative energy sources by FY 1985. The Department of the Interior's report iden. tified 20 projects in wind power technology for potential application at Interior sites. Examples of the types of wind power applications include wind powered generators, chargers, and windpowered lighting.

While many renewable energy demonstration programs are underway, renewable energy sources represent a very small portion of the government's fuel use at present. Use of renewable energy sources can be expected to grow as these resources become increasingly attractive due to rising costs of conventional energy sources.

Fuel substitution programs continue to be pursued by many Federal agencies. The Department of Energy has an investment program for fuel conversion projects to reduce its dependence on fuel oil and natural gas by 1995. As part of this effort, a fuel selection policy banning new installations from burning natural gas and requiring new major fuel burning installations to be coal fired or convertible to coal has been instituted. DOE is also evaluating state-of-the-art developments such as fluidized bed technology, coal gasification, and coal-oil mixtures.

\section{Related Programs}

Several energy conservation programs are sponsored by the Federal Government that are not specifically included in the guidance of Executive Order 12003, but are nevertheless part of the overall commitment of the government to manage and control its energy use. While these programs are outside the strict interpretation of direct energy reduction for the Federal Government, they do support our na. tional energy goals.

Examples of these related programs include solar energy demonstration projects, geothermal programs, fuel substitution programs (including coal conversion), employee car pooling and van pooling, wastepaper recycling, and the evaluation of alternate fuels.

Many agencies have instituted car pooling programs and have distributed parking spaces on a car pool priority system. Where facilities are available, agencies also cooperate in com. puterized car pool matching services. Van pools are operated by many of the larger agencies. The Tennessee Valley Authority has a total of 375 van pools and 47 full size commuter buses in operation. It is estimated that this program saved two million gallons of gasoline for the nation during FY 1978. In larger cities, agencies also promote the use of mass transit both for employee commuting and for interagency trips. It should be noted that some van pooling programs have the effect of increasing Federal energy use, as a means to reduce societal energy use. This effect occurs when fuel which would be used by contractors or Federal employees in non-Federal vehicles is replaced in a van pooling program by fuel used in Federally owned vans.

The General Services Administration has an ongoing program to retread truck tires and has retreaded almost a million tires since FY 1975. Energy savings are realized through displacing that equivalent amount of primary petroleum which would have been required for a new tire. At a cost from FY 1975 to FY 1978 of $\$ 20.3$ million, the program has resulted in a cost 
avoidance of over $\$ 38$ million and energy use avoidance contributions of over 2.3 trillion Btu. To date, wastepaper recycling operations of GSA have resulted in over 122,000 tons being sold with proceeds of over $\$ 4.25$ million.

Federal research and development programs that are aimed at the practical development of biomass or refuse as an energy source could have important implications for both the Federal and private sectors. Many of these programs are already in operation on a small scale. The Tennessee Valley Authority is oper. ating several projects to demonstrate the value of wood burning stoves, wood chip furnaces, construction methods for energy efficient homes, including earth berming and burial, and application of solar assisted heat pumps.

More detailed information on these and additional related programs is contained in Appen$\operatorname{dix} A$ of this report.

\section{ENERGY MANAGEMENT IN GENERAL OPERATIONS}

\section{Background}

The General Operations Energy Management Program includes the management of all ener. gy used by Federal agencies in performing their daily missions and functions, such as energy used for general vehicle transportation, services, production or industrial type activities, and for training and operational readiness functions. It specifically excludes the energy used to operate buildings, which is reported under the Buildings Energy Management Program.

Energy used within buildings for industrial or process purposes, which is not reported as part of the building energy use, is reportable under General Operations. For example, industrial or process energy could include: energy used to operate machinery, to run chemical processes, or in research and development. The amount of energy used for these and related purposes within buildings can only be determined by metering the energy use of these processes separately from building energy use.

Such separate metering is uncommon at present. Because a certain amount of energy used in the General Operations program continues to be reported under the Buildings Program, agencies must consider this in their plans to add new metering capabilities. As a result, separately identifiable energy use is anticipated in the future.

Specific energy conservation goals for General Operations programs are not identified in Executive Order 12003. Instead, the identification of such goals has been the responsibility of individual agencies. Goals are to be established for reductions in energy use; productivity is to be shown through separate goals for energy efficiencies. Each agency is required to prepare and implement plans for achieving its goals and to report annually on program status. DOE will review and approve these plans. Goals can be simple, such as reducing the use of automobile gasoline by five percent, or more complex, particularly where the agency operates a wide variety of vehicles and industrial processes.

As the missions and operating responsibility of Federal agencies vary widely, the General Operations energy conservation program consists of a series of diverse sets of agency specific programs and activities. The individual agency energy conservation strategies shall be tailored to take advantage of the various opportunities provided by or developed within individual operational program structures.

\section{General Operations Profile}

The agencies of the Federal Government are engaged in a wide range of operations to meet national needs in such areas as defense, law enforcement, construction, agriculture, the environment, space exploration, land and water resource management, health, education, power production, and communications. In the performance of these missions, energy is used to provide power for:

- 106,832 1 automobiles (including 94,249 sedans and 12,583 station wagons);

\footnotetext{
1 Source: General Services Administration, Annual Federal Motor Vehicle Fleet Report, September, 1979.
} 
- More than $400,000^{2}$ tactical mission related vehicles, ships, aircraft, and other equipemnt;

- More than 23,000 Federal installations on 741 million acres of land.

\section{General Operations' Fuel Mix}

A comparison of the percentages of various types of fuels used for general operations in FY 1975 and FY 1978 is shown in Table 2-3. About 400,000 barrels equivalent of petroleum fuels were used each day in FY 1978, almost threetourths of which were for aircraft operations.

An examination of Table 2-3 discloses the following relationships:

- Energy use for general operations decreased $9.3 \%$ overall between FY 1975 and FY 1978.

2 Source: Approximation based ón General Services Administration, Annual Federal Motor Vehicle Fleet Report, September, 1979, and Department of Defense tactical and mission-related vehicle estimates.
- Between FY 1975 and FY 1978, the absolute quantities of fuel in each category (except LPG) diminished; and

- In percentage terms, jet fuel and automotive gas claimed larger proportions of the total in FY 1978 than FY 1975. All other fuel categories showed a slight decrease as a proportion of the operation's fuel mix.

\section{Planning for General Operations}

The Department of Energy has drafted proposed guidelines: (1) to facilitate energy conservation in the general operations of Federal agencies; and (2) to promote contingency planning. Such planning is intended to reduce the impact upon Federal agencies of a sudden reduction in oil-based energy resources or electricity. The draft guidelines require all Federal agencies to establish energy management plans that include individual agency-selected 10-year goals for energy reductions and energy efficiencies, baselines through 1990, and in-

\section{TABLE 2-3. Major Fuel Types Used in General Operations (FY 1975 and FY 1978)}

\begin{tabular}{|c|c|c|c|c|c|c|}
\hline \multirow[b]{2}{*}{ General Operations } & \multicolumn{3}{|c|}{ FY 1975} & \multicolumn{3}{|c|}{ FY 1978} \\
\hline & Btu $\times 10^{9}$ & $\begin{array}{l}\text { Percent } \\
\text { of } \\
\text { Gen. Op. }\end{array}$ & $\begin{array}{c}\text { Percent } \\
\text { of Total } \\
\text { Energy Use }\end{array}$ & Btu $\times 10^{9}$ & $\begin{array}{c}\text { Percent } \\
\text { of } \\
\text { Gen. Op. }\end{array}$ & $\begin{array}{c}\text { Percent } \\
\text { ul Tutal } \\
\text { Energy Use }\end{array}$ \\
\hline Jet Fuel & $642,352.2$ & 71.2 & 35.6 & $601,192.0$ & 73.5 & 35.5 \\
\hline Diesel \& Distillate & $159,265.6$ & 17.6 & 8.8 & 142.388 .8 & 17.4 & 8.5 \\
\hline Auto Gas & $62,562.6$ & 6.9 & 3.5 & $59,936.9$ & 7.3 & 3.5 \\
\hline Navy Special & $21,311.1$ & 2.4 & 1.2 & $7,988.6$ & 0.9 & 0.5 \\
\hline Aviation Gas & $16,346.9$ & 1.8 & 0.9 & $6,220.7$ & 0.8 & 0.3 \\
\hline & 30.5 & 0.0 & 0.0 & 31.4 & 0.0 & 0.0 \\
\hline Total & $901,888.9$ & 100.0 & 50.0 & $817,758.4$ & 100.0 & 48.2 \\
\hline
\end{tabular}

Source: Department of Energy Quarterly Energy Use Reports 
vestment programs. Decentralized goal setting by each agency will assure that overzealous actions to reduce energy consumption do not lead to a serious degradation of the primary agency mission. The Department of Energy has circulated the draft guidelines so agencies that are represented in the Interagency Federal Energy Policy Committee, the "656" Committee, can review and comment on the guidelines before they are issued.

The draft General Operation guidelines establish a series of actions to be taken by Federal agencies to effect energy use reduction. Such action will include the use of a specific methodology for establishment of energy reduction and efficiency goals; iden. tification of appropriate baselines for charting and evaluating progress toward agency goals; formulation of long-term investment plans for achievement of goals; adoption of specific conservation measures; development of contingency plans; and establishment of specific evaluation and reporting procedures. Each such action shall be undertaken in accordance with a time-phased program coordinated with the Department of Energy and the 656 Committee. The guidelines are designed to assure the earliest possible implementation of known cost-effective energy conservation measures without jeopardizing fundamental agency functions or missions.

Because the missions and operating responsibilities of Federal agencies vary widely, general operations planning consists of diverse sets of agency-specific programs, projects and activities. Agency reports indicate that most major and many smaller energy-using agencies have ongoing programs to train, motivate, and educate employees; to review and revise ad. ministrative practices in order to make them more energy efficient; to eliminate unneces. sary travel; to purchase fuel-efficient automobiles and other equipment; to curtail unnecessary activities; and to improve operational scheduling and capital equipment maintenance. The proposed guidelines will provide procedures to use these different agency plans in developing an overall Federal 10-year plan for energy management in the area of general operations, in order to reinforce ongoing energy conservation efforts. They are also expected to provide a broader and more coordinated planning effort aimed toward achieving greater reductions and efficiencies in energy use.

Historically, the monitoring and reporting of energy use data for general operations has been confined to the energy used in vehicles and equipment. Energy used in industrial processes, utilities, and research and development operations has not been included. The various reporting categories have now been clarified. Energy efficiency goals are in the process of being developed by each agency. The following specific functional categories were suggested:

- General Transportation: To include vehicles used for over the road driving as opposed to vehicles designed for off road conditions, aircraft and marine vessels;

- Industrial/Production: Buildings and plants which normally use large amounts of capital equipment (e.g., Governmentowned, contractor-operated plants) to produce goods (hardware) or provide services;

- Services: Functions which are less energy intensive than industrial/production and are normally labor intensive, e.g., delivery of mail, laboratories (not categorized as buildings) involved in research and development rather than production;

- Training/Operational Readiness: Selfexplanatory or as selected by the agency;

- Other: A function established to accom. modate those activities which use energy but do not fit into one of the other categories.

\section{Energy Conservation Progress in General Operations}

Agency reports show that although considerable progress has been made by the Department of Defense in reducing energy used for general operations, civil agencies have increased their consumption in this area. In FY 1978 , the total amount of energy used annually in general operations was 9.3 percent less than the base line level in FY 1975 . This reduction represents almost 15 million barrels of oil equivalent. Of this 9.3 percent overall reduc. tion, 10.2 percent is attributable to use reductions by the Department of Defense. Civilian 
agencies increased their consumption by 7.5 percent during the period.

Of all the agencies, only DOD has shown a continuous downward trend over the entire period. However, it is important to note that DOD reduced field activities during this time period. 11 of the 18 largest energy using agencies have higher general operations energy use in FY 1978 than they did in the FY 1975 base year. These mixed results should not necessarily be interpreted as failure to comply with the legislative and executive order mandates in that the data do not reflect improvements in the efficiency of energy use that are offset by increased agency missions.

Energy use in general operations is frequently impacted by modifications to agency missions, international events, or other factors that are outside the agency's control. For example, increased general operations energy use has been observed in the Department of Transportation since FY 1975 due to the additional responsibilities of the U.S. Coast Guard for monitoring the 200 mile Fisheries Management Zone and for increased drug interdiction efforts. Energy use in the Department of Defense has been impacted by NATO exercises and other fleet movements. Production of electric power by the hydroelectric plants of the Panama Canal Companyl Canal Zone Government is highly dependent on the level of water in the reservoirs. In FY 1976, the PCC/CZG generated more power than in any other year since the plants were constructed. FY 1977 was a dry year, and less hydroelectric power was generated than ever before, resulting in over 15 percent of power requirements being purchased from the Government of Panama.

Nonetheless, more remains to be done in the General Operations Program. Agencies are continuing to pursue policies, programs, and procedures aimed at improving future productivities. Energy reduction trends can improve with the increased application of existing programs and through the development of new approaches. Presently, emphasis is being placed on actions such as the following:

- The purchase of smaller, more energy efficient automobiles and light trucks for the Federal fleet;

- Curtailment of automobile use for ad- ministrative purposes, and more efficient scheduling of trips;

- The use of simulators to replace energy intensive training operations;

- Review of research and development equipment and operations to optimize energy use;

- Additional purchases and evaluations of electric vehicles;

- Purchase of more energy efficient capital equipment to include automatic data processing equipment;

- Restriction of large-scale, energy-intensive exercises to the minimum level required to maintain proficiencies and the require: ment of an energy analysis as part of the planning process. Additionally, emphasis is placed upon efforts to reduce energy use when operating mission equipment during training exercises;

- Control of temporary duty or business travel to maximize other means of communication, such as telephone and multipurpose staff visits.

More detailed information on these and other programs in contained in Appendix $A$ of this report.

\section{Specific Progress in Transportation}

The use of more than 21 million gallons of gasoline was avoided in transportation operations between FY 1975 and FY 1978. The bulk of this reduction resulted from the continuing trends toward smaller, more energy efficient automobiles in the Federal fleet. The impetus for this reduction originated in Executive Order 12003, which provided for mandatory programs to assure that:

- That fleet average fuel economy surpasses the annual minimum statutory requirement (1) for fiscal year 1978 by two miles per gallon, (2) for fiscal year 1979 by three miles per gallon, and (3) for fiscal years 1980 and after by four miles per gallon;

- Executive agencies do not acquire, subsequent to FY 1977, any passenger auto- 
mobile unless such automobile meets or surpasses the average fuel economy standard for the appropriate model year;

- Each class of nonpassenger automobiles acquired by all Executive agencies in each fiscal year, beginning with fiscal year 1979, achievès for such fiscal year a fleet average fuel economy standard for the appropriate model year.

Vehicles designed to perform combat related missions for the Armed Forces, or designed to be used in law enforcement work and emergency rescue work, were specifically excluded from these requirements. In addition to these objectives, the Presidential Memorandum of April 10, 1979, directed an additional reduction of 10 percent in automotive fuel use.

Since FY 1975, agencies have increased the number of smaller automobiles in their fleets and have reduced the number of mid-size and larger vehicles. Figure 2-2, based on data from the General Services Administration, shows the numbers and categories of sedans in the Federal fleet for FY 1975 through FY 1978. The number of large sedans has been reduced from 54,192 in FY 1975 to 23,487 in FY 1978. At the same time, the number of compact sedans has risen from 12,361 to 46,142 . Continued reductions in the numbers of larger sedans are anticipated as each agency reviews its own needs and regulated purchases.

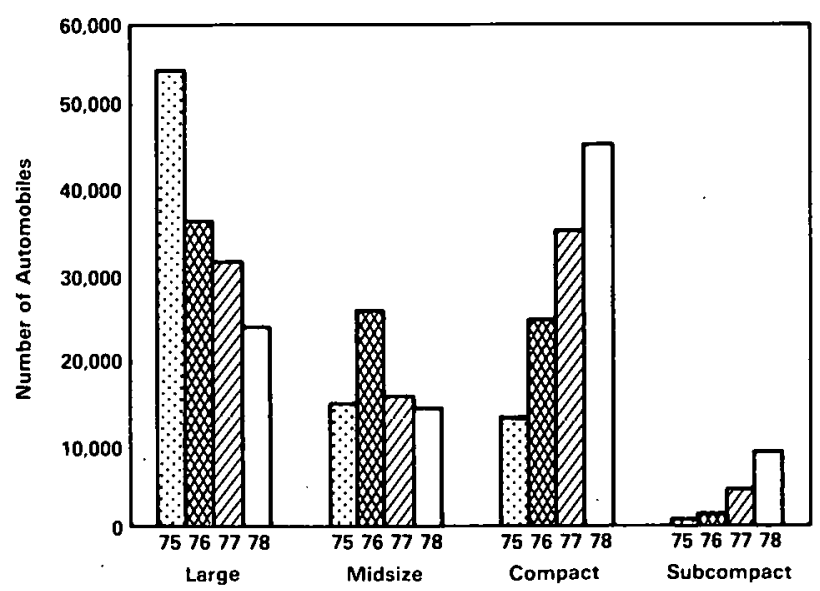

Source: General Services Administration, Federal Motor Vehicle Fleet Report. Sept. 1978.

Figure 2-2. Number of Federally Owned Automobiles by Categories
In figure 2.3 the Federal and national fleet averages for new car purchases are compared. Federal fuel economy data was not reported prior to FY 1977. New sedans purchased for the Federal fleet in Fy 1978 averaged 21.0 miles per gallon, which is one mile per gallon above the Federal fleet average fuel economy goal for the year, and 1.4 miles per gallon above the national average for new cars.

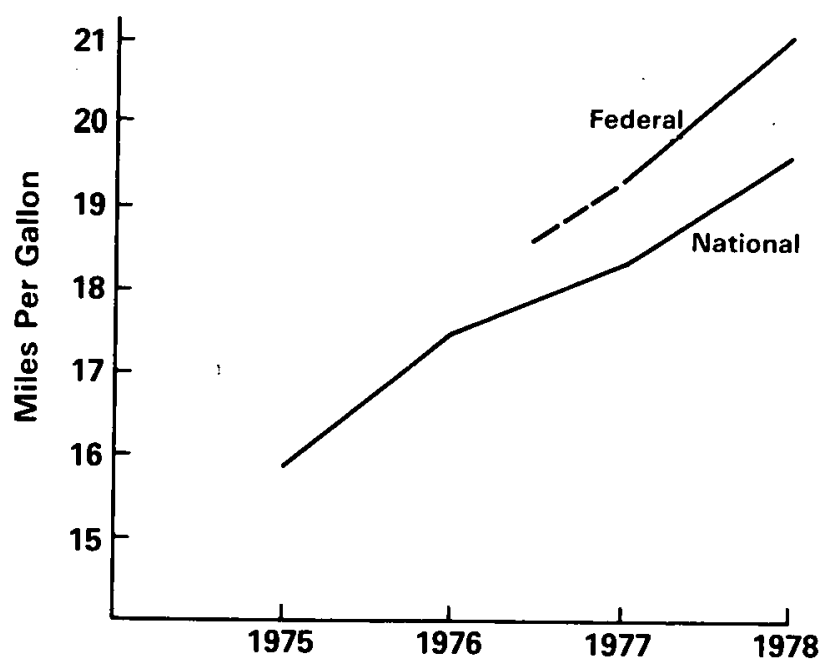

Source: General Services Administration, Federal Motor Vehicle Fleet Report, Sept. 1978; Dept. of Energy Studies

Figure 2-3. Federal and National Fleet Average MPG for New Car Purchases

\section{ANALYSES OF MAJOR ENERGY USING AGENCIES}

\section{Introduction}

The following section presents three major groups of information for each of the 18 major energy using agencies: (1) a brief analysis of existing energy-related programs compared to a comprehensive program spectrum; (2) a summary of the data items which agencies submitted to DOE in their annual reports; and (3) total energy use since FY 1975, accompanied by notes on specific problems encountered in energy use data contained in agency annual reports. The first two analyses are presented in matrix format, based upon an examination of the annual report submitted by the agencies. 


\section{Agency Programs}

The substantive content of agency energy program varies widely. Figure 2.4 shows the results of a brief analysis of existing agency programs compared to a comprehensive program spectrum. (It is recognized that some agencies may have programs in existence that were not mentioned in their report.) Figure 2-4 is useful for examining the coverage of various programs. For example, 17 agencies reported "energy conservation retrofit projects in existing buildings", while two agencies reported programs to control "one-person/one-car travel".

\section{Agency Reporting Chronology and Associated Problems}

Executive Order 12003 requires that executive agencies: (1) develop plans and establish goals covering the energy aspects of their agency operations; and (2) by July 1st of each year, submit a report to DOE of progress in meeting these plans and goals. The executive order requires DOE to provide guidance to the agencies for their annual report submissions. The order further requires DOE to consolidate agency reports into a single report for submission to the President by August 15th.

At the time agency input was needed for this Second Annual Report, DOE had not issued the final planning guidelines for the Buildings Section of agencies' plans and had not drafted the guidelines for the General Operations Section. Because guidelines were not formally published, DOE issued suggested instructions and format for this year's agency report submissions on June 20, 1979. Sixty-eight agencies were requested to provide input for this second annual report. More extensive program information was requested from large energy using agencies than from smaller ones (less than 100 billion Btu per year).

Due to the proximity of the mandated reportsubmission date to the President, agencies were given only until July 2, 1979, to submit their annual reports, which were needed for consolidation by DOE. As this was a very short response time, written agency reports were received and accepted until late July, 1979. Telephone changes, clarifications and additions to these written reports were received durIng late July and early August.
The annual reports received from the agencies in response to the request for input varied in content, detail, and format. These problems were aggravated by the lack of advance DOE guidance for agencies and by the short reports. Figure 2-4 summarizes which agencies reported important data items. Examination of Figure 2-5 shows the lack of uniformity among agency reports. (Certain significant data inconsistencies are discussed in individual agency analyses below.)

\section{Analysis of Energy Use of 18 Major Agencies}

This section is a briel analysis by DOE of each major energy using agency's total energy use Irom FY 1975 through FY 1978. Each analysis is based upon quarterly energy use data provided to DOE by the agency, as presented in Table 2-1. This quarterly energy use reflects the status as of September 30,1978 , and includes amendments through that date.

\section{DEPARTMENT OF DEFENSE}

The Department of Defense's total energy use in FY 1975 was $1,466,706.1$ billion Btu, and $1,362,746.7$ billion Btu in FY 1978 (Figure 2-6). The 7.1 percent reduction in the energy use level from the FY 1975 baseline is equivalent to a - reduction of 103,959.4 billion Btu between FY 1975 and $F Y$ 1978. This is more than 97 percent of the total usage reduction by all agencies in

DEPARTMENT OF DEFENSE

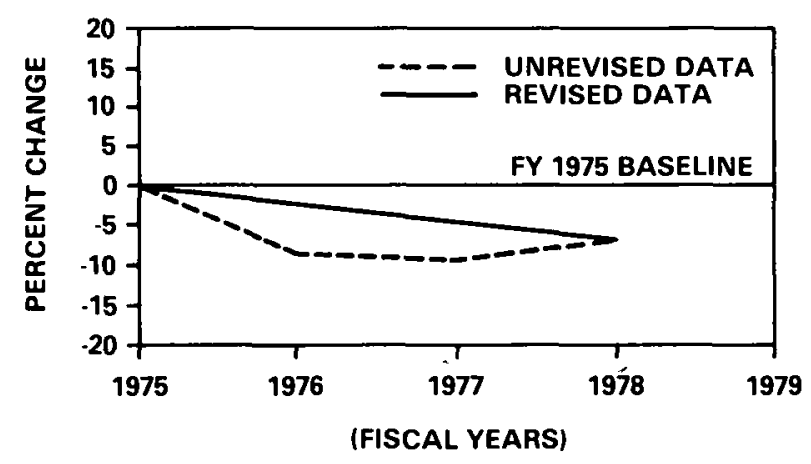

Figure 2-6. Percent Change in Total Energy Use by the Department of Defense Compared to FY 1975 Baseline. 


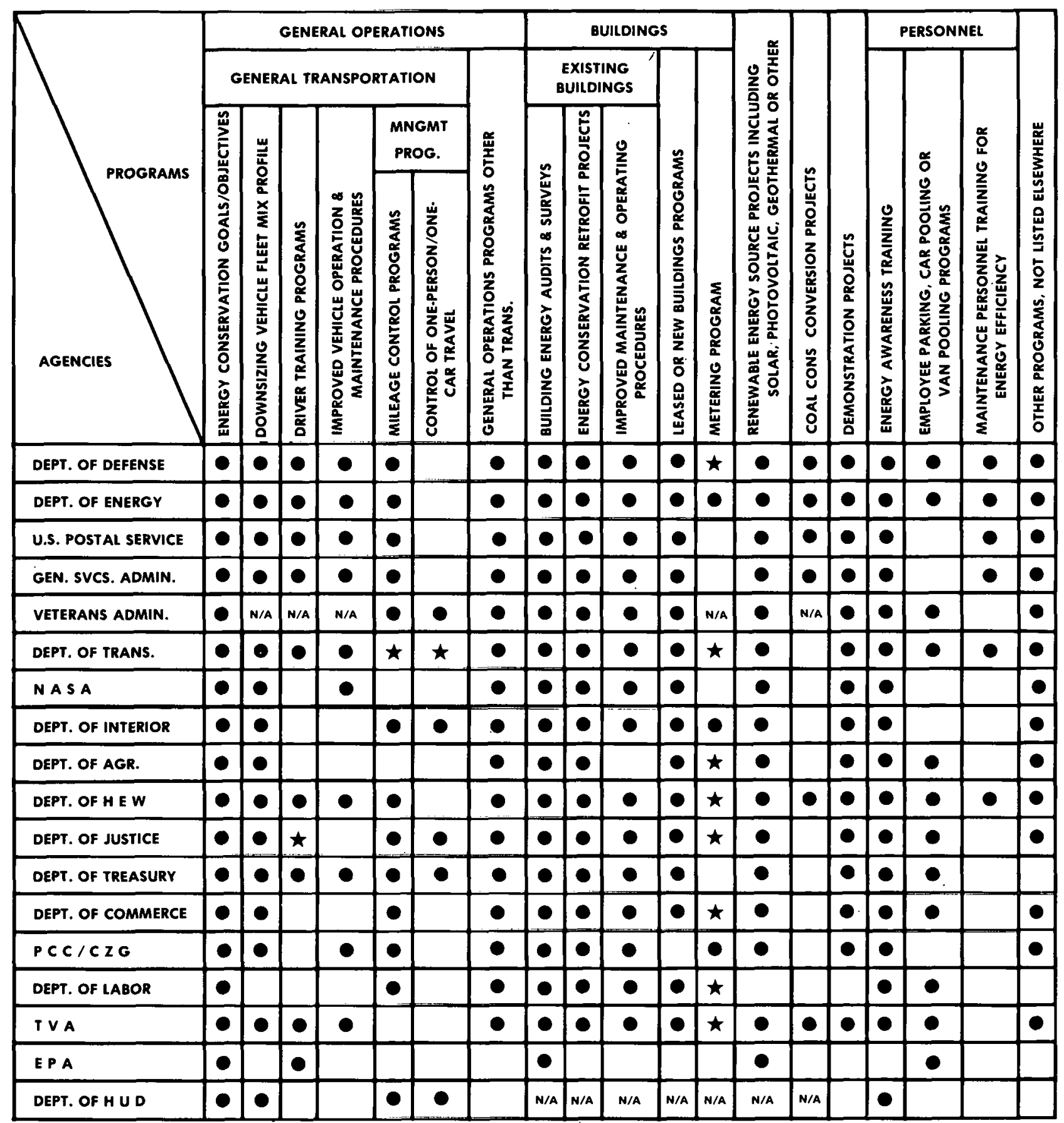

LEGEND: BULLETED (•) PROGRAMS/PROJECTS ARE INCLUDED IN THE AGENCY REPORTS. N/A MEANS THAT THE PROGRAM IS NOT APPICABLE TO THIS AGENCY.

^ MEANS THAT THE PROGRAM IS INCOMPLETE IN THAT IT IS MENTIONED IN THE AGENCY REPORT BUT DOES NOT APPEAR TO BE COMPREHENSIVE.

Figure 2-4. Evaluation of Agency Reports Against a Comprehensive Program Spectrum (Evaluation based upon information derived from Agency reports). 


\begin{tabular}{|c|c|c|c|c|c|c|c|c|c|c|c|c|c|c|c|c|c|c|}
\hline DATA ITEMS & 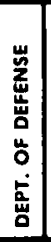 & 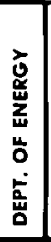 & 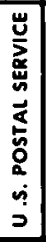 & 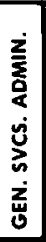 & 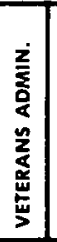 & 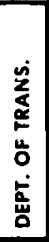 & $\begin{array}{l}a \\
\vdots \\
0 \\
2 \\
2\end{array}$ & 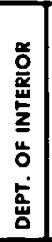 & 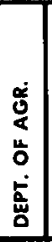 & 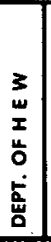 & 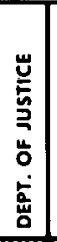 & 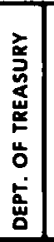 & 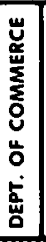 & $\begin{array}{l}u \\
N \\
u \\
u \\
u \\
0\end{array}$ & 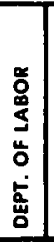 & $\$$ & $\begin{array}{l}\infty \\
\vdots \\
\end{array}$ & 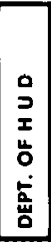 \\
\hline \multicolumn{19}{|l|}{ OVERALL PROGRAM } \\
\hline TOTAL ENERGY U SE IN BłU (FY 1978) & - & - & - & - & - & - & & - & 0 & $\bullet$ & $\star$ & $\star$ & 9 & - & - & $\star$ & - & $\star$ \\
\hline CUMULATIVE ENERGY SAVINGS IN BTU & - & - & - & 9 & 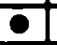 & & & 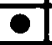 & - & ? & $\star$ & & 0 & 9 & 9 & $\star$ & & \\
\hline TOTAL PROGRAM COST & - & - & $\star$ & $\star$ & $\star$ & 으 & $\star$ & 운 & & & & & & $\star$ & & & & \\
\hline TOTAL PROGRAM COST SAVINGS & - & e & & & 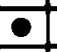 & $\star$ & $\star$ & & & & & & & 0 & & - & & \\
\hline $\begin{array}{l}\text { ANALYSIS OF FUEL USE/SAVINGS BY } \\
\text { FUEL CATEGORIES } \\
\end{array}$ & - & - & - & - & - & $\star$ & & - & $\bullet$ & - & $\star$ & - & - & - & • & - & - & - \\
\hline \multicolumn{19}{|l|}{$\begin{array}{l}\text { QUANTIFIED INDICATION OF DEGREE OF } \\
\text { GDAL ATTAINMERIT }\end{array}$} \\
\hline $\begin{array}{l}\text { OVERALL IMPROVEMENT OVER THE FY } 1975 \\
\text { DASELINE IN DTU }\end{array}$ & $\bullet$ & - & • & - & - & $\bullet$ & & • & - & $\bullet$ & $\star$ & $\star$ & ? & - & - & $\star$ & & $\star$ \\
\hline FY 1975 BASELINE ENERGY USE & - & - & - & - & e & - & & - & - & - & $\star$ & - & $\bullet$ & 9 & - & $\star$ & 0 & 은 \\
\hline $\begin{array}{l}\text { SUMMARY OF ENERGY CONSERVATION } \\
\text { PROJECTS }\end{array}$ & - & - & - & - & - & - & $\bullet$ & - & • & $\bullet$ & - & - & - & $\bullet$ & • & $\bullet$ & $\bullet$ & - \\
\hline SUMMARY OF ANY BENEFITS REALIZED & - & ? & e & 9 & - & $\star$ & e & 2 & & & & ? & 9 & 9 & & 2 & & \\
\hline OTHER, NOT DISCUSSED ELSEWHERE & e & - & 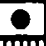 & - & ?. & 9 & 9 & & & & & & & & & 0 & & \\
\hline \multicolumn{19}{|l|}{ GENERAL OPERATIONS } \\
\hline TOTAL ENERGY USE IN BYU (FY 1978) & - & & 0 & 으 & N/A & 0 & & 0 & 0 & 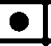 & $\star$ & & - & 0 & 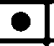 & $\star$ & 인 & $\star$ \\
\hline TOTAL PROGRAM COST & 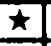 & & & $\star$ & N/A & $\star$ & $\star$ & 0 & & & & & & & & & & \\
\hline TOTAL PROGRAM COST SAVINGS & $\star$ & & $\star$ & & N/A & $\star$ & $\star$ & & & & & $\star$ & & & & & & \\
\hline $\begin{array}{l}\text { ANALYSIS OF FUEL USE/SAVINGS BY } \\
\text { FUEL CATEGORIES }\end{array}$ & - & - & - & - & $\mathbf{N} / \mathbf{A}$ & - & & $\bullet$ & - & $\bullet$ & $\star$ & - & - & $\bullet$ & - & $\star$ & - & $\bullet$ \\
\hline \multicolumn{19}{|l|}{$\begin{array}{l}\text { QUANTIFIED INDICATION OF DEGREE OF } \\
\text { GOAL ATTAINMENT }\end{array}$} \\
\hline $\begin{array}{l}\text { OVERALL IMPROVEMENT OVER THE FY } 1975 \\
\text { BASELINE IN BTU }\end{array}$ & - & • & - & • & $N / A$ & - & & - & • & $\bullet$ & $\star$ & $\star$ & - & & $\bullet$ & $\star$ & • & $\star$ \\
\hline FY 1975 BASELINE ENERGY USE & 는 & 0 & ㄴ. & 0 & N/A & 9 & & 인 & e & 인 & $\star$ & & 0 & & 0 & $\star$ & - & - \\
\hline $\begin{array}{l}\text { NUMBERS AND TYPES OF ADMINISTRATIVE } \\
\text { VEHICLES OWNED OR LEASED }\end{array}$ & & & 0 & & $\mathrm{~N} / \mathrm{A}$ & $\bullet$ & & & & - & 9 & & 9 & $\bullet$ & - & & & \\
\hline \multicolumn{19}{|l|}{ BUILDINGS } \\
\hline TOTAL ENERGY USE IN BTU (FY 1978) & 운 & 으 & 9 & ? & - & 인 & & - & - & 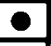 & $\star$ & & - & - & 9 & $\star$ & 은 & N/A \\
\hline TOTAL PROGRAM COST & - & 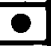 & - & $\star$ & - & $\star$ & $\star$ & & - & & & - & & & & : & & N/A \\
\hline TOTAL PROGRAM COST SAVINGS & & 9 & 0 & $t$ & e & \pm & \pm & & & & & - & & $\cdot$ & & & & N/A \\
\hline $\begin{array}{l}\text { ANALYSIS OF FUEL USE/SAVINGS BY } \\
\text { FUEL CATEGORIES }\end{array}$ & - & - & - & - & - & - & & $\bullet$ & - & $\bullet$ & & - & - & - & 0 & $\star$ & - & N/A \\
\hline $\begin{array}{l}\text { QUANTIFIED INDICATION OF DEGREE OF } \\
\text { GOAL ATTAINMENT }\end{array}$ & & & & & & & & & & & & 0 & & & & & & N/A \\
\hline $\begin{array}{l}\text { OVERALL IMPROVEMENT OVER THE FY } 1975 \\
\text { BASELINE IN BtU }\end{array}$ & $\bullet$ & - & - & 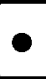 & $\bullet$ & - & & - & • & • & & $\star$ & - & & - & $\star$ & & N/A \\
\hline FY 1975 BASELINE ENERGY USE & -1 & 은 & - & 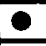 & 은 & e & & 0 & 0 & e & $\star$ & & - & & 0 & $\star$ & - & N/A \\
\hline TOTAL GROSS SQUARE FOOTAGE & & & $\star$ & & 으 & 은 & & 인 & & 9 & $\downarrow$ & e & 9 & & & $\star$ & & N/A \\
\hline AVERAGE ENERGY USE IN BłU/GSF & & & $\star$ & $\star$ & 0 & - & & 0 & & 0 & $\star$ & & $\star$ & $\star$ & & & & N/A \\
\hline
\end{tabular}

LEGEND: BULLETED ( $\bullet$ ) ITEMS ARE INCLUDED IN THE AGENCY REPORTS.

N/A MEANS THAT THE ITEM IS NOT APPLICABIE TO THIS AGENCY.

$\star$ MEANS THAT THE ITEM IS INCOMPLETE OR INCONSISTENT.

Figure 2-5. Evaluation of Agency-Submitted

Data Items Against a Comprehensive Data

Spectrum. 
FY 1978, as compared to FY 1975. Most of this reduction was achieved in FY 1978 as the. product of reduced field activity.

\section{DEPARTMENT OF ENERGY}

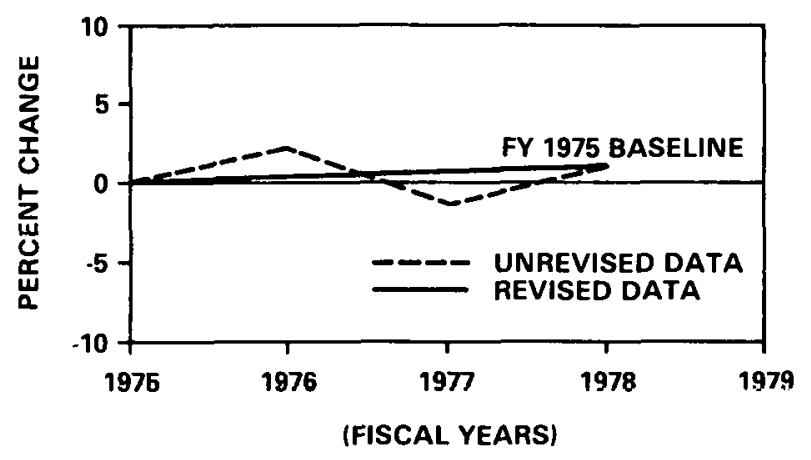

Figure 2-7. Percent Change in Total Energy Use by the Department of Energy Compared to FY 1975 Baseline.

The Department of Energy's (DOE) consumption of energy for $F Y 1975$ was $86,816.1$ billion Btu and 87,031.2 billion Btu for FY 1978. The FY 1975 and $F Y 1978$ data do reflect changes in the Department's mission. Figure 2.7 indicates an increase in energy use of 0.2 percent (215 billion Btu) between FY 1975 and FY 1978.

These statistics do not include the energy used by the uranium enrichment plants operated by DOE. In 1978 DOE's operations at these plants used 394.7 trillion Btu of electricity which would equal over 23 percent of total reported Federal energy use. If this energy use were added to total department-wide use, DOE's energy use would increase by over 81 percent. Energy use of the gaseous uranium enrichment plants is excluded in DOE's report partially because of the strategic nature of those plant's operations. Some energy is converted into stored energy in the form of nuclear fuel and weapons.

Figure 2-7 indicates the percentage change in total energy use in FY 1978, as compared to the DOE FY 1975 baseline. Wide ranging energy conservation measures are underway throughout the department including a study of potential uses for the nearly 400 trillion Btu of waste heat generated annually by the gaseous diffusion plants and reactors on the Savannah River.

\section{UNITED STATES POSTAL SERVICE}

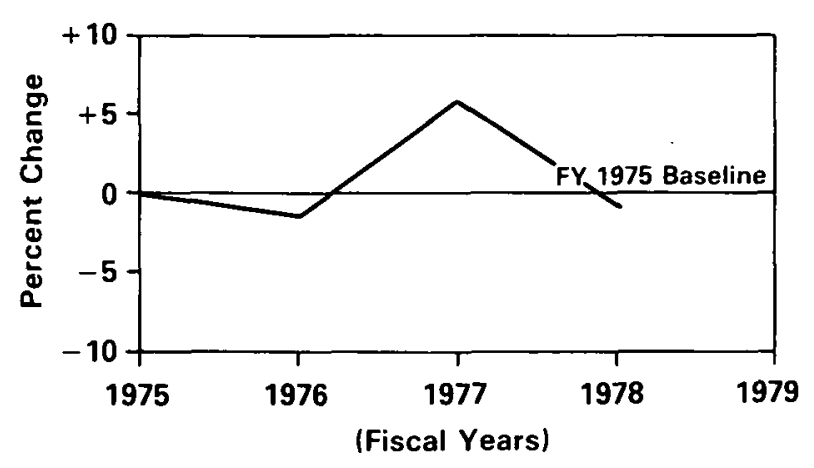

Figure 2-8. Percent Change in Total Energy Use by the United States Postal Service Compared to FY 1975 Baseline.

Energy use by the United States Postal Service was 55,510.0 billion Btu in FY 1975 and 54,912 billion Btu in FY 1978. Based upon these data overall energy use in the USPS during $F Y$ 1978 was almost 597 billion Btu or 1.1 percent less than during FY 1975, despite a 14.6 percent increase in its building inventory and a 9.9 per. cent increase in its vehicle fleet (Figure 2-8). Additionally, a reduction of 3.5 percent has been achieved in total energy use during the first two quarters of FY 1979.

The USPS report shows information on per unit building energy use in Btu/GSF. The calculations were performed using a Btu conversion factor for electricity of $3,413 \mathrm{Btu} / \mathrm{kWh}$. This is a correct conversion factor but inconsistent with the standard conversion factor $11,600 \mathrm{Btu} /$ $k W h$ prescribed for Federal reporting. The Federal conversion factor reflects the raw source energy consumed in the production of a kilowatt hour of electricity. Thus, the USPS per-unit figure is inconsistent with the magnitude of per-unit figures which other agencies might report using the prescribed raw-source-energy conversion factor. Nonetheless, these per-unit use figures show FY 1978 usage to be less than FY 1975 usage on a per-gross-square-foot basis. GENERAL SERVICES ADMINISTRATION

The General Services Administration (GSA) used 44,868.7 billion Btu in the baseline year, FY 1975, and 44,622.9 billion Btu in FY 1978. The FY 1978 figure represents a 0.5 percent decrease (246 billion Btu) below the baseline.

Data originally supplied to DOE in their Second Annual Report indictes that GSA energy 


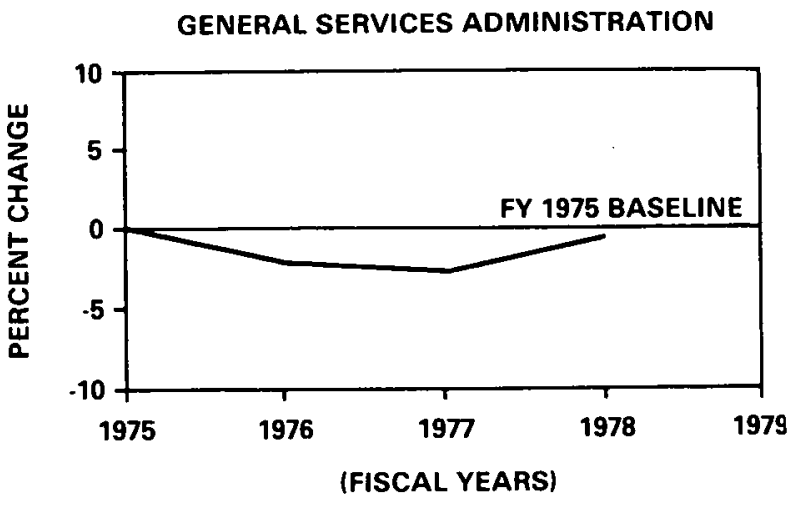

Figure 2.9. Percent Change in Total Energy Use by the General Services Administration Compared to FY 1975 Baseline.

use decreased from 44,968 billion Btu in baseline Fy 1975 to 44,730 billion Btu in FY 1978. The percentage change in total energy use compared to FY 1975 is displayed in Figure 2-9. Revised general operations energy use was 184.1 billion Btu in FY 1975 and 169.8 billion Btu in FY 1978. Although the Second Annual Report suggests a 4.8 percent use reduction the revised figures indicate the actual reduction is closer to 7.8 percent.

Over 99 percent of the GSA's total energy use is in buildings. By FY 1975, total building energy use had already been decreased by approximately 30 percent from FY 1973 levels. Total building energy use data in FY 1978 shows a reduction of one-half of one percent from that used in the base year of 1975. Revised energy use data for buildings during FY 1975 and $F Y 1978$ are $44,684.6$ and $44,453.1$ billion Btu respectively.

\section{VETERANS ADMINISTRATION}

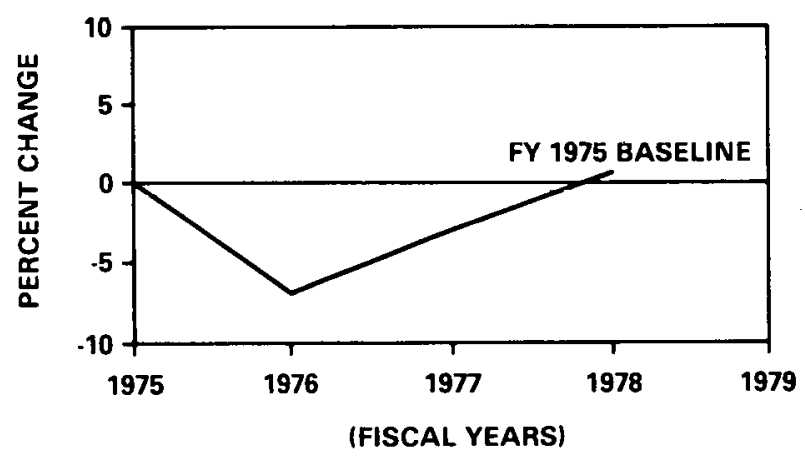

Figure 2-10. Percent Change in Total Energy Use by the Veterans Administration Compared to FY 1975 Baseline.
Energy use by the Veterans Administration was $39,207.5$ billion Btu in FY 1975 and $39,444.9$ billion Btu in FY 1978. The energy use level for FY 1978 was 0.6 percent (237 billion Btu) above the FY 1975 baseline. Between FY 1975 and FY 1978 , energy use in buildings increased by 0.6 percent while energy use in general operations decreased by 1.7 percent. Overall energy use trends since $F Y 1975$ are shown in Figure 2-10. The Veterans Administration achieved an overall reduction of 7 percent in FY 1976, compared to $F Y 1975$, despite a 2 percent increase in energy used for general operations. Between FY 1976 and FY 1978, energy use increased steadily at four percent a year.

\section{DEPARTMENT OF TRANSPORTATION}

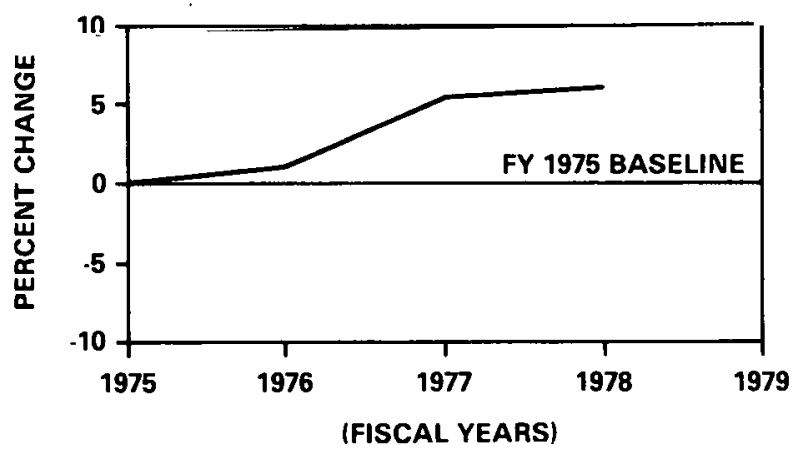

Figure 2-11. Percent Change in Total Energy Use by the Department of Transportation Compared to FY 1975 Basseline.

The Department of Transportation's total energy use was $26,834.5$ billion Btu in FY 1975 and $28,431,3 \mathrm{Btu}$ in FY 1978 . This is an overall Increase in energy use of 6.0 percent over the FY 1975 base level (Figure 2-11). For vehicle and equipment operations, energy use increased 13.3 percent over the FY 1975 base level. Expanded mission responsibilities are the primary reason for these increases.

Between FY 1975 and FY 1978, energy use in general operations increased 13.3 percent while energy use in buildings increased less than 0.8 percent. General operations accounted for 44.1 percent of total energy use in FY 1978, as opposed to 41.2 percent FY 1975.

Concurrently, the total square footage of DOT's building space increased by more than 18. percent (according to the Agency's report). 
DOT reports a decrease of over 15 percent in per-unit building energy use (i.e., Btu/GSF) between FY 1975 and FY 1978. Building energy use accounted for 55.9 percent of total energy use in FY 1978, as opposed to 58.2 percent in FY 1975. This combination of circumstances appears indicative of greater efficiency in building energy use.

\section{NATIONAL AERONAUTICS AND SPACE ADMINISTRATION}

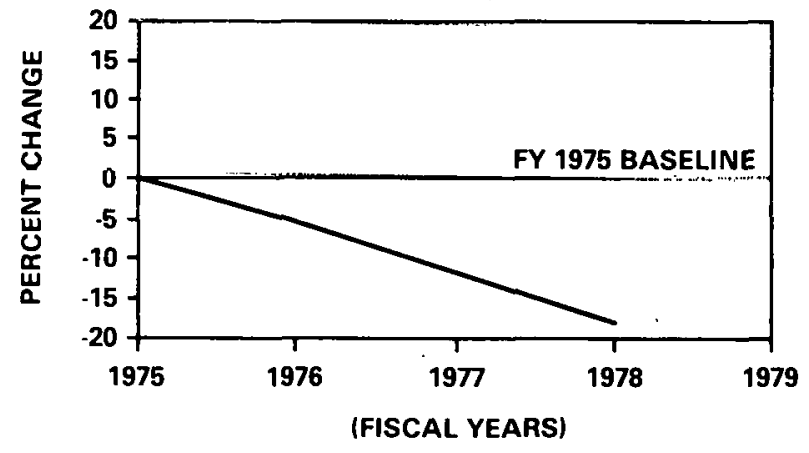

Figure 2-12. Percent Change in Total Energy Use by the National Aeronautics and Space

Administration Compared to FY 1975 Baseline.

The quarterly data submitted to DOE by the National Aeronautics and Space Administration indicates that energy use was $27,244.8$ billion Btu and 22.479 .5 billion Btu in Fy 1975 and Fy 1978 respectively. The energy use level for FY 1978 was 17.5 percent below the level recorded in FY 1975. During the period FY 1977 to FY 1978, energy use was reduced 6.6 percent. Figure 2.12 indicates the energy use trends for NASA from FY 1975 to FY 1978. The energy use in buildings in FY 1978 had declined almost 18.7 percent as compared to FY 1975. However, over the same period energy use for general operations has increased 0.6 percent. In FY 1978, NASA reported that only 7.6 percent of their total energy use was in general opera. tions, while the remaining 92.4 percent was used in buildings.

\section{DEPARTMENT OF INTERIOR}

The Department of the Interior's total energy use was 12,244.8 billion Btu in FY 1975 and $12,449.8$ billion Btu in FY 1978. This data shows a 0.02 percent decrease in total energy used as compared to FY 1975 (Figure 2-13). Between FY 1975 and FY 1978 energy use in buildings

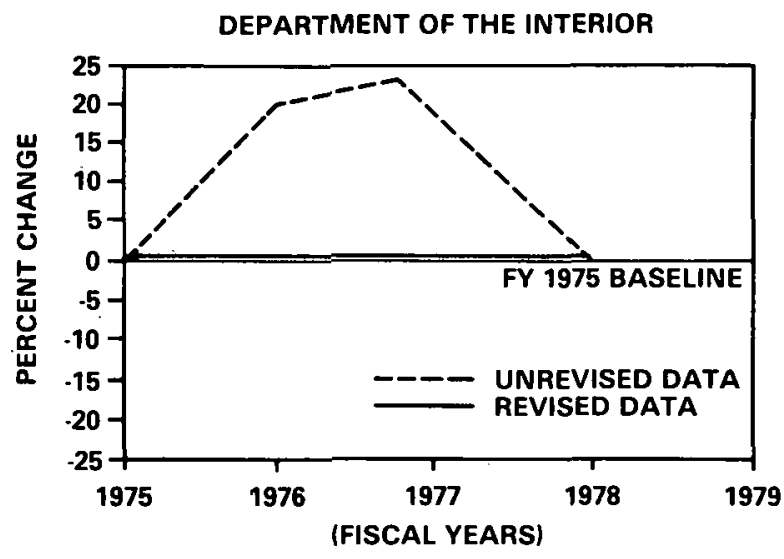

Figure 2-13. Percent Change in Total Energy

Use by the Department of the Interior Compared to FY 1975 Baseline.

decreased by 1.2 percent. Between FY 1975 and FY 1978, energy use in general operations increased 2.6 percent. Between FY 1975 and FY 1978, energy use in general operations increased 2.6 percent. A four year trend cannot be identified here because the Department of the Interior's Data for FY 1976 and FY 1977 have not been adjusted to reflect changes in the Department's mission responsibilities.

\section{DEPARTMENT OF AGRICULTURE}

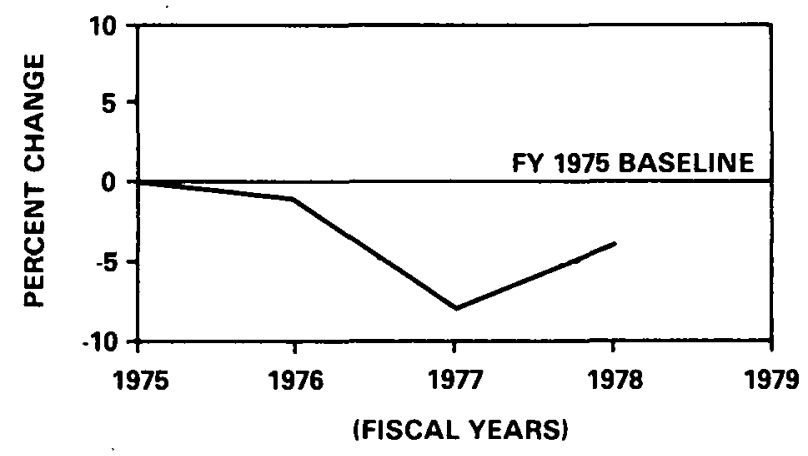

Figure 2-14. Percent Change in Total Energy Use by the Department of Agriculture Compared to FY 1975 Baseline.

The Department of Agriculture's total energy use for FY 1975 was $11,928.8$ billion Btu. The energy use level for FY 1978 was $11,222.8$ billion Btu or 5.9 percent below the level recorded in FY 1975. However, from FY 1977 to FY 1978 the agency showed a 4.7 percent increase in energy use based on data reported to DOE. Figure 2-14 indicates the energy use trends for 
USDA from FY 1975 to FY 1978. In FY 1978, as compared to $F Y 1975$, energy use in buildings decreased by more than 19 percent while energy use in general operations increased by 11.4 percent. Vehicle transportation energy use amounted to 51.4 percent of the Department energy use in FY 1978, with buildings using the remaining 48.6 percent.

\section{DEPARTMENT OF HEALTH, EDUCATION AND WELFARE}

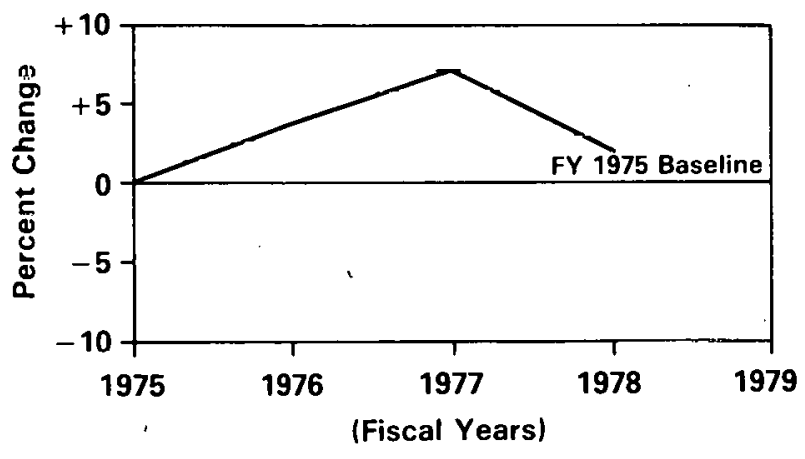

Figure 2-15. Percent Change in Total Energy Use by the Department of Health, Education, and Welfare Compared to FY 1975 Baseline.

HEW's total energy use in FY 1975 was 9,259.5 billion Btu. The total during FY 1978 was $9,439.2$ billion Btu which represents an increase of more than 1.9 percent when compared to FY 1975. Between FY 1977 and FY 1978, energy use was curtailed by more than 4.8 percent through conservation actions, reversing a rising trend (Figure 2-15). During FY 1978, HEW used 8,782 billion Btu of energy in buildings and 657.2 billion Btu in vehicles. These quantities are in comparison to FY 1975, when 8,521.1 billion Btu of energy were used in buildings and 738.4 billion Btu were used in vehicles. These figures represent a three percent increase in building energy use and an 11 percent decrease in gasoline use.

\section{DEPARTMENT OF JUSTICE}

Total energy use for the Department of Justice was $6,689.7$ billion Btu in FY 1975. The total energy use in FY 1978 was up more than seven percent over the FY 1975 base level to 7,167.3 billion Btu (Figure 2-16). However, the FY 1978 energy use did represent a decline from the prior year.

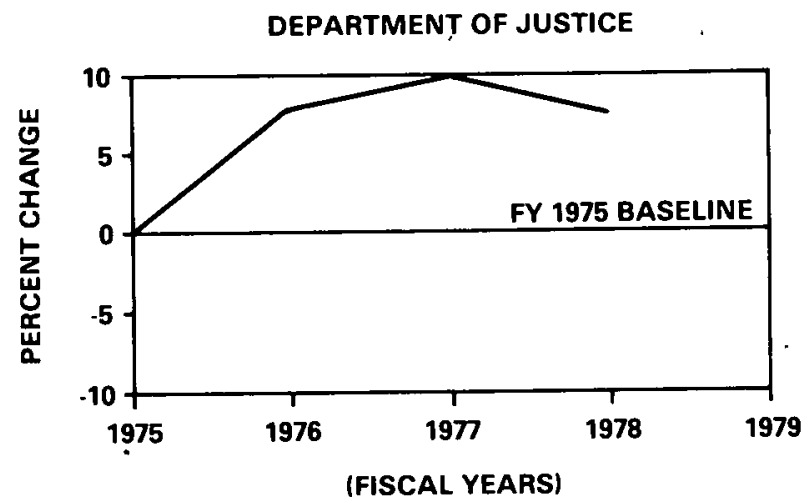

Figure 2-16. Percent Change in Total Energy Use by the Department of Justice Compared to FY 1975 Baseline.

Energy use in the buidings of DOJ showed a decrease of 2.9 percent from FY 1977, but was still 7.7 percent over the FY 1975 baseline. Building energy use accounted for 70.7 percent of total energy use in FY 1978 as opposed to 72.3 percent in FY 1975.

\section{DEPARTMENT OF THE TREASURY} DEPARTMENT OF THE TREASURY

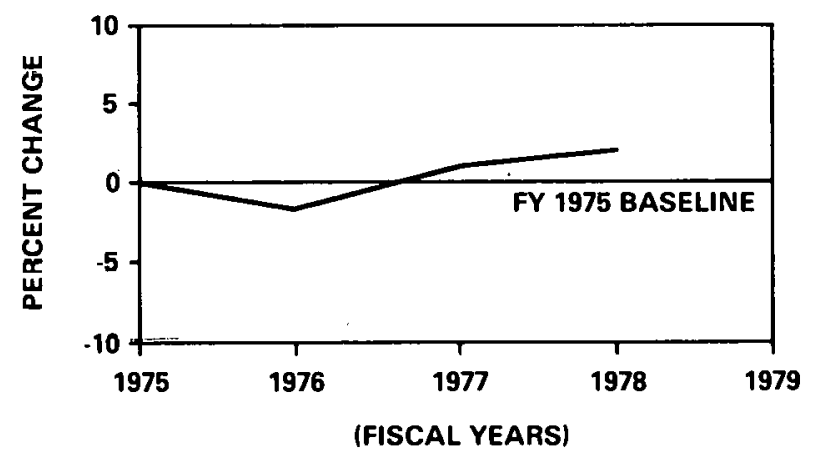

Figure 2-17. Percent Change in Total Energy Use by the Department of the Treasury Compared to FY 1975 Baseline.

The Treasury Department's total energy use was $4,238.7$ billion Btu in FY 1975, and 4,322.3 billion Btu in FY 1978, representing a 1.9 percent increase in energy use between FY 1975 and FY 1978 (Figure 2-17).

The Treasury Department's report does not show energy use for the FY 1975 baseline year. However, the DOE data indicate that an upward trend in energy use of approximately two percent per year has occured during FY 1977 and FY 1978 after a reduction in total energy use in FY 1976. 


\section{DEPARTMENT OF COMMERCE}

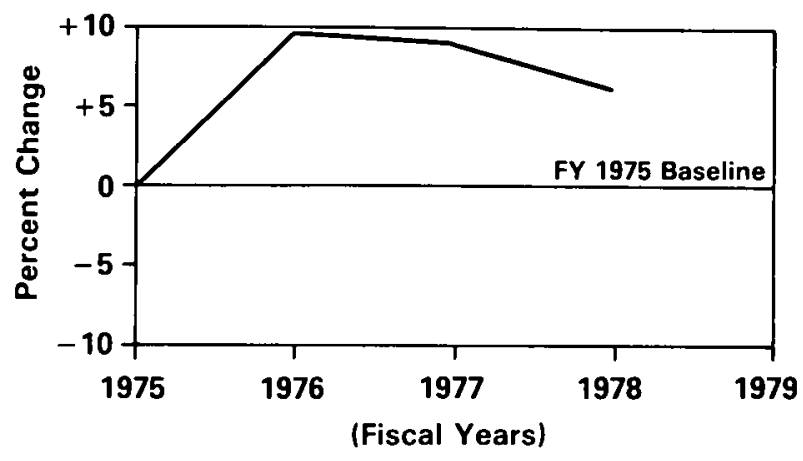

Figure 2-18. Percent Change in Total Energy Use by the Department of Commerce Compared to FY 1975 Baseline.

'The Department of Commerce's total energy use in FY 1975 was 3,515.7 billion Btu and in FY 1978 was $3,792.4$ billion Btu, a 7.8 percent increase (Figure 2-18).

The agency report states that for the first half of FY 1979, the total energy use was 2,057 billion Btu, a continued uptrend. Increased total energy use occurred in both the General Operations and Buildings Program between FY 1975 and FY 1978.

A 19.3 percent increase in energy use in the General Operations Program is reported to be due to:

- Increased activity in the Bureau of the Census in preparation for the 1980 census, requiring increased automotive travel;

- Travel by personnel of the recently established U.S. Fire Administration, which was not included in the FY 1975 base year statistics;

- Increased jet fuel usage by the National Weather Service due to increased storm. watch flight requirements;

- Increased ship activity in the National Oceanic and Atmospheric Administration and the Maritime Administration resulting in additional diesel and ship fuel usage.

The Commerce Department reported annual per unit energy use figures for FY 1975 and $F Y$ 1978 of 535,900 and 399,500 Btu/gsf, an apparent reduction in Btu/gsf (and corresponding increases in building energy efficiency) of over 25 percent. Detailed analysis of the Depart- ment's report shows these energy-efficiency indicators to be spurious.

Within the Buildings Program, the Department reported total energy use of 2.46 trillion Btu in FY 1975 for 130 buildings that contained over 5,000 square feet. An average of 535,900 Btu/gsf/yr. was used to heat the $4,581,315$ square feet of available space.

In FY 1978 the Department reported total energy use of 2.44 trillion Btu for its 255 buildings with over 1,000 square feet. This represents $6,165,015$ square feet of space and an average of $399,500 \mathrm{Btu} / \mathrm{gsf} / \mathrm{yr}$. The space in the addition 125 buildings between 1,000 and 5,000 square feet represents 34.5 percent of the FY 1975 reported spaces.

Thus between FY 1975 and FY 1978, total building energy use (the numerator of Btu/gsf) remained relatively constant. The respective square footage denominators of Btu/gsf changed substantially, however. The reported square feet of space for FY 1975 did not include over 25 percent of the Department's space reported for FY 1978 (e.g., 125 buildings between 1,000 and 5,000 square feet). Further, neither the FY 1975 nor the FY 1978 square footage figures included any buildings which may have less than 1,000 square feet of space.

\section{PANAMA CANAL}

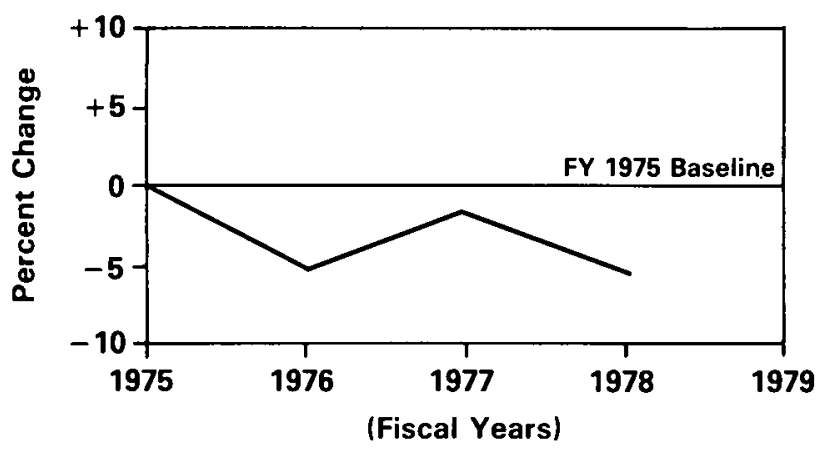

Figure 2-19. Percent Change in Total Energy Use by the Panama Canal Company/Canal Zone Government Compared to FY 1976 Baseline.

Energy use by the PCC/CZG totaled 2.705.1 billion Btu in FY 1975 and 2,516.4 billion Btu in FY 1978. Cumulative energy use reductions since FY 1975 totaled 189 billion Btu. Total energy use was seven percent lower in FY 1978 
than in the FY 1975 base year (Figure 2-19). Reductions have been registered in both building and energy use for general operations. Preliminary energy use figures for FY 1979 indicate energy usage is only about 2.6 percent below the FY 1975 baseline.

A substantive reduction in the $P C C / C Z G$ energy management program will occur after October 1, 1979, when the Panama Canal Treaty becomes effective and a large number of existing operations and buildings will be transferred to the Government of Panama. Similarly, the operation of schools and hospitals will be transferred to the Department of Defense. Energy management activities will be continued in the remaining buildings.

\section{DEPARTMENT OF LABOR}

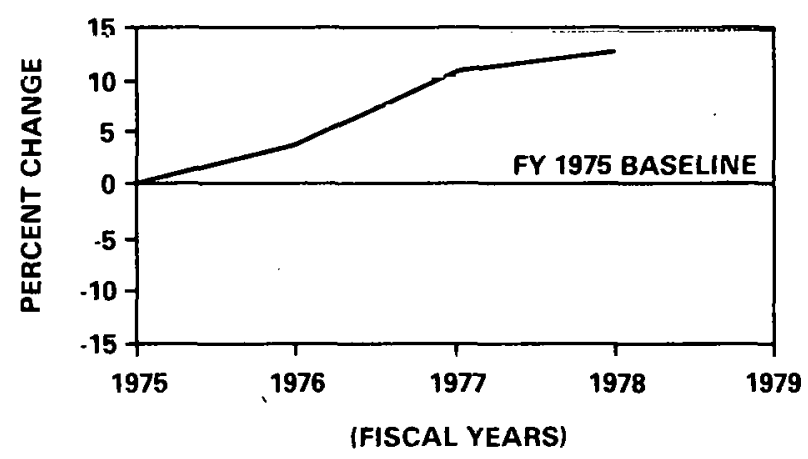

Figure 2-20. Percent Change in Total Energy Use by the Department of Labor Compared to FY 1975 Baseline.

The Department of Labor's total energy use was 1,578.3 Btu in FY 1975 and 1,771.2 billion Btu in Fy 1978 which represents an increase of 12.2 percent above the FY 1975 baseline level (Figure 2-20). This increase in reported energy use is attributable to a 49 percent increase in gasoline use for automobile transportation between FY 1975 and FY 1978. During FY 1978, several changes in mission have adversely affected energy management. Most agencies of DOL have experienced increases in personnel, inspection responsibilities, legal support requirements, and personal visits for data collection tasks.

\section{TENNESSEE VALLEY AUTHORITY}

The Tennessee Valley Authority's total energy use in FY 1975 was 764.3 billion Btu and $1,081.2$ billion Btu in FY 1978. The FY 1978

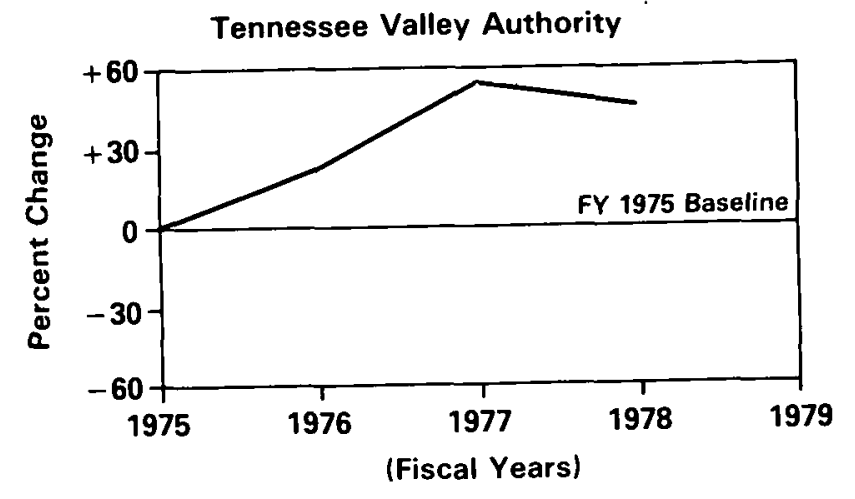

Figure 2-21. Percent Change in Total Energy Use by the Tennessee Valley Authority Compared to FY 1975 Baseline.

energy use is approximately 41 percent higher than the FY 1975 baseline level (Figure 2-21).

Transportation energy use increased by 18 per cent and building energy use increased 88 percent compared to FY 1975 levels. It should be noted, however, that in that same period, employment nearly doubled (increasing the miles driven), and total occupied space increased 86 percent.

Energy use data in the TVA report is inconsistent with other agency reports. The energy content of fossil fuel used in generating electricity was reported using a Btu conversion factor determined by laboratory testing rather than the conversion factor prescribed for Federal reporting.

\section{ENVIRONMENTAL PROTECTION AGENCY}

The Environmental Protection Agency's total energy use was 559.9 billion Btu in FY 1975 and 595.4 billion Btu in FY 1978, which is an in-

ENVIRONMENTAL PROTECTION AGENCY

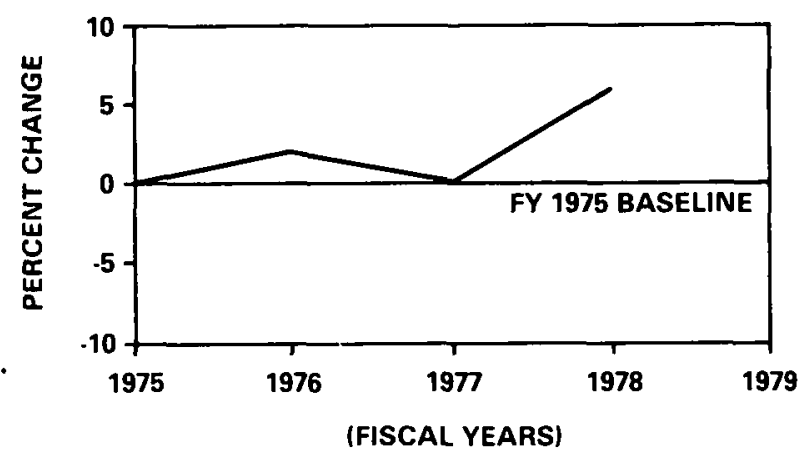

Figure 2-21. Percent Change in Total Energy Use by the Environmental Protection Agency Compared to FY 1975 Baseline. 
crease of six percent between FY 1975 and FY 1978 (Figure 2-22). Energy use in buildings in $F Y$ 1978 was 11 percent above that used in FY 1975 while a reduction in energy use of 8.5 percent has been recorded for vehicle operations over the same period.

\section{DEPARTMENT OF HOUSING AND URBAN DEVELOPMENT}

The Department of Housing and Urban Development's total energy usage in FY 1975 was 375.0 billion Btu and in FY 1978 was 336.5 billion $B$ tu, a reduction in use of over 10 percent compared to the FY 1975 baseline (Figure 2-23). The Department achieved a significant decrease in its energy use level (17.8 percent) in FY 1976 as compared to FY 1975. Between FY 1976 and FY 1978, however, energy use as compared to the previous year has been increasing (2.4 percent in FY 1977 and 6.7 percent in FY 1978).

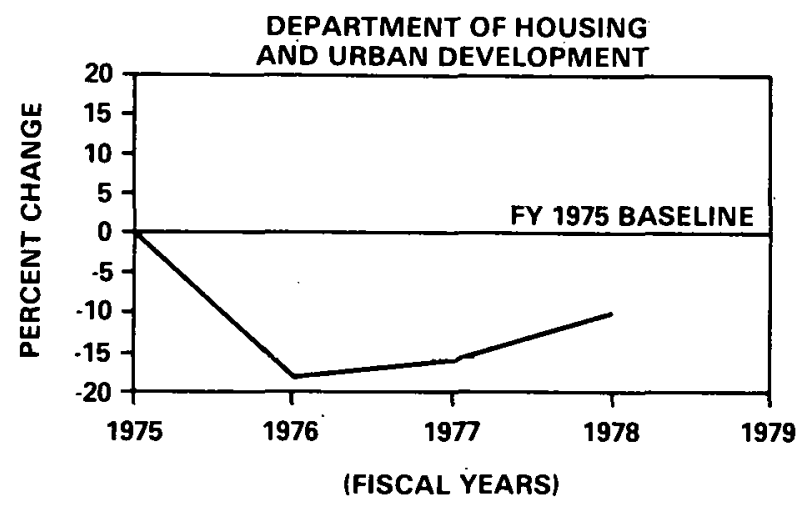

Figure 2-22. Percent Change in Total Energy Use by the Department of Housing and Urban Development Compared to FY 1975 Baseline. 
THIS PAGE

\section{WAS INTENTIONALLY LEFT BLANK}




\section{FUTURE ACTIVITIES AND PROGRAM RECOMMENDATIONS}

Some executive departments and agencies have achieved energy reductions between. FY 1975 and $F Y$ 1978, with accomplishments in both the Buidings and General Operations Program areas. Nevertheless, there are a number of reasons to believe that overall performance should be improved significantly.

- Agency top management commitment is often lacking.

- Data inconsistencies and discrepancies exist in agency energy use, fuel mix, and inventory figures for buildings and equipment.

- Detailed Federal planning for Buildings and General Operations Programs has not been sufficiently developed by DOE for ' agency use thus far. During 1979, FEMP guidance was provided in the form of General Operations planning and lifecycle costing guidelines; more is needed.

- Many agencies have not developed energy conservation plans. The plans of those agencies that have are often incomplete, insufficient in detail, or inconsistent with DOE guidance.

- The energy use of a number of agencies has increased above corresponding levels in the FY 1975 baseline year. Other agencies have used increasing amounts of energy in recent years but still show a lower level of energy use in FY 1978 than FY 1975.

- Major increases in the use of non-critical fuels, such as coal, have not occurred. Such changes should be taking place as part of the Federal effort in fuel-switching away from critical fuels. Equally important, the use of renewable energy sources, such as solar, remains at a low level.

It is uncertain what greater improvement could have been realized beyond that actually achieved through FY 1978. A plateau in performance might have resulted under any program scenario simply because the easy, quick, and inexpensive actions to save energy were taken prior to FY 1975. The subsequent years have been, in fact, a period for developing and im. plementing programs that will not realize actual reductions in energy use for some time to come. Building audits and surveys need to be performed to identify energy conservation opportunities. Investment funds have to be planned, programmed and budgeted. Finally, equipment needs to be modified, renovated, or installed. Only then can further significant reductions in energy use occur.

While a major downturn in energy use may be possible, the prospect seems unlikely in the near future. Preliminary FY 1979 data indicate a slight upward trend in energy use over FY 1978. Key planning functions are years behind schedule in certain instances.

It is imperative for the Federal Government to regain the energy conservation initiative that appears to have been lost during the middle 1970 's. This is especially true in view of: (1) the importance of energy conservation to the nation; (2) the past leadership role of the Federal Government; and (3) the impact of rapidly increasing fuel prices on Federal budgets. Therefore, it seems prudent for the Executive Branch to strengthen the Federal Energy Management Program's efforts as it strives to replicate these important experiences within the public sector. There exists a critical need for explicit and proven energy conservation methods in the public sector.

\section{FUTURE FEMP PLANS}

Opportunities lie ahead to strengthen the FEMP activities within the Executive Branch and to provide for the critically important task of replicating the Federal energy maangement experiences in the public sector. In view of these opportunities, the Department of Energy is planning to implement a revitalization effort to meet the following program objectives:

- To develop and implement a cost effective program to conserve critical energy sources through improved efficiency and 
prudent fuel conservation measures in the Federal Government. The program shall meet, as a minimum, prescribed goals as required by law and specify measures for meeting these goals for buildings, facilities and overall operations within the Federal Government.

- To develop program management guidelines, procedures and standards to insure program uniformity and consistency. Develop overall program recommendations for Executive Office consideration and program investment determinations for the Office of Management and Budget in order to support prudent allocation of Federal resources.

- To develop a public sector program which will be specifically designed to allow direct replication in the public sector of appropriate, demonstrated methods based upon the Federal Government program and its energy management measures, products and initiatives. 'Prospective user groups in the public sector include residential, industrial, commercial, transportation, and state and local government sectors of the economy.

\section{FUTURE PROGRAM STRATEGIES}

To assure public sector replication of proven energy management measures, the Federal Government must demonstrate its leadership in a highly visible manner. This will require some realignment and strengthening of the Federal Government's program. Once this has been accomplished, the resultant examples will form a solid foundation for potential public sector replication.

To be effective in the public sector, the FEMP initiatives will need to be tailored for ease of duplication by the end-users within the public sector. Because end-user needs differ, initiatives will have to be developed which are responsive to these users' specific requirements. FEMP program initiatives must be presented in a detailed, non-technical manner so that they can be easily understood. Thus, they are more likely to be implemented.
It is important to prepare documentation of conservation measures which are currently successful and proven. Additionally, program activities must be developed which will rapidly integrate new technologies and renewable resources into the program as they become cost-beneficial and proven. Specific strategies to be reviewed and considered for inclusion in future FEMP program plans are as follows:

- Develop demonstrated energy conservation and efficiency methods for public sector use in the near term (1980-1985).

- Use and demonstrate near-term backstop technologies for improved energy efficiencies for Federal use in the near term and for subsequent public sector use in the midterm (1985-2000).

- Develop and implement highly visible and cost-effective demonetratione of renew. able resources in Government buildings, facilities and general operations.

- Develop the methodology to use replacement-cost pricing of fuels in the costeffectiveness analyses of the Federal Energy Management Program.

- Develop a more effective transportation program for the Federal Government and for subsequent public sector use.

- Develop and implement, for potential Federal and public sector use, a continuing technical evalualion process lo ideritify:

- New, emerging technologies; and

- Existing energy-saving products and services.

- Develop and disseminate guidelines, documentation of successful conservation measures, and standards for reducing the use of critical fuels including:

- Switching from oil to natural gas (dual capability where cost effective); and

- Use of coal in new boiler installations.

- Develop an on-going program for public education regarding proven Federal Government initiatives. The purposes of this program will be to:

- Conserve energy use through energy efficiencies in buildings and general operations. 
- Reduce the quantities of critical fuels used and promote the conversion to noncritical and renewable fuel sources.

To improve the quality of energy use data gathering within the Federal Government, DOE will determine the overall cost-effectiveness of the following options:

- Installation of permanent metering devices;

- Utilization of portable and clamp-on metering devices;

- Engineering estimating techniques; and

- Etatietical application of sampling methods supported by measuring or estimating techniques.

The Department of Defense is currently studying the cost-effectiveness of metering family housing. The results of this analysis will be coupled with FY 1979 DOE research into the use of portable metering equipment. These two studies will be evaluated and specific guidelines will be prepared by DOE and provided to the Federal agencies. This effort should significantly reduce current difficulties with energyuse data within the Federal agencies. Accurate energy-use information such as that provided by metering, is needed as part of the analytical process to determine cost-effective investments for reducing energy use.

DOE plans to strengthen its planning and technical guidance efforts to meet the needs of the Federal agencies, to eliminate redundancy, and to assure consistency of efforts toward program goals. Some specific examples of the technical guidance to be provided are:

- 10-Year Overall Strategy Plan for buildings and general operations;

- Mandatory building standards for new and existing Federal buildings;

- Contingency planning factors;

- Guidelines for alternate fuel utilization; and

- Replacement cost prices for use in life cycle cost analyses.

DOE will also investigate the feasibility of better coordinating some of its programs to enhance the overall Federal effort. Demonstration programs from the various technology areas within DOE are now being implemented through separate actions with individual agencies. The overall planning, priority-setting, and information sharing aspects of these activities will be examined to determine if better coordinated efforts can be made that will improve the existing effectiveness of Federal energy management significantly. 
THIS PAGE

\section{WAS INTENTIONALLY LEFT BLANK}




\section{APPENDIX A \\ PROGRAM HIGHLIGHTS}

The following pages present brief descriptions of many agency projects that have contributed to the Federal Energy Management Program. These projects illustrate the innovative techniques that have been applied, and also reflect the dedication and contributions of Federal employees.

The most visible energy savings have been achieved by those agencies that are the largest energy users, but energy savings have also been reported by many of the smaller energy using agencies. While the energy savings of these agencies may be large when compared with total Federal energy use, they have made their own important contributions. Typical actions taken to reduce energy use include:

- Procurement of smaller, more efficient automobiles

- Energy surveys and retrofit programs for buildings

- Curtailment of travel and automobile use

- Reduction of lighting, and thermostat adjustments

- Equipment replacement and maintenance programs

- Implementation of employee energy awareness programs

- Van pooling, car pooling, and employee parking programs.

The description of energy conservation projects which follows is organized to generally parallel the FEMP reporting categories. Highlights are organized under the following categories: (A) Operational Readiness, (B) Transportation Programs, (C) Research, Industrial, and Utilities, (D) Buildings and Facilities Retrofit, (E) Solar Energy Projects, (F) Resource Recovery, (G) Employee Awareness, and $(\mathrm{H})$ Related Programs.

\section{A. OPERATIONAL READINESS Hull Cleaning Reduces Ships's Energy Use}

Because marine growths increase the drag of a ship's hull, additional power is needed to maintain speed, and consequently energy use increases. About six percent of a ship's fuel use can be saved by periodic hull cleaning (Figure $5-1)$. The Navy has embarked upon a program of hull cleaning while its ships are afloat, which is significantly less costly than drydocking. About 300 days after drydocking, a hull maintenance program is begun. The hulls of ships are then cleaned on a quarterly basis to remove marine fouling.

Cyclical cleaning is only an interim solution, however, as it is most desirable to eliminate the marine fouling altogether. The Navy is working on other approaches to prevent marine fouling, such as ultrasonic prevention of biofouling and organometallic polymer coatings, which may result in a considerable reduction in marine growths and consequent reductions in propulsion energy requirements.

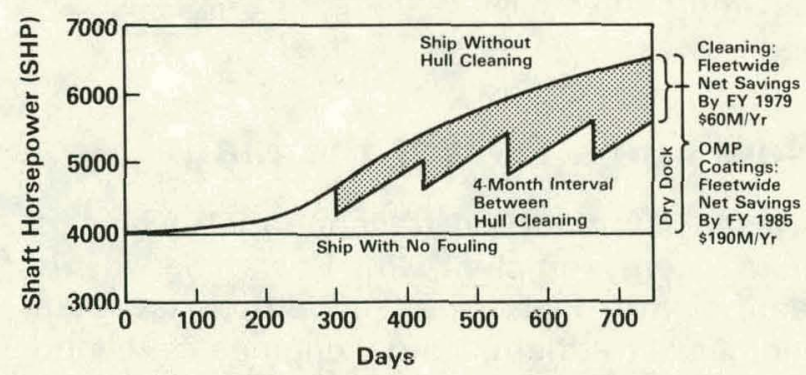

Figure 5-1. Hull Cleaning Saves Energy 


\section{Strobe Lights Improve Visibility and Save Energy}

Incandescent aircraft warning lights on the Edward R. Murrow transmitting station of the Voice of America were recently replaced with strobe light units. The new lights resulted in energy savings of 35 kilowatts per hour of operation, amounting to 1.5 million Btu per year. In addition to providing significant energy savings, the new lights have also improved the visibility of the towers from aircraft. The Edward R. Murrow station is operated by the International Communication Agency.

\section{Defense Studies Alternatives for Mobility}

The Department of Defense is studying a number of ways to improve the energy efficiency of its mobile (tactical) equipment and to use alternative energy sources.

Examples of mobility energy technology application programs include:

- Production, refining, and testing of 80,000 barrels of shale-derived fuels in military equipment

- Development of energy efficient tactical vehicles, such as diesel engine onequarter ton trucks

- Development of a replacement transmission for the M113 armored personnel carrier which can reduce fuel consumption more than 20 percent

- Development of aircraft, ship, and ground vehicle propulsion systems that can use synthetics as well as a broader range of petroleum-based fuels.

\section{New Fuels Deliver the Mail}

In an effort to find transportation which is more energy efficient, the Postal Service is testing hydrogen-fueled modified gasoline engines, stratified charge engines, a hybrid electric behicle (in cooperations with DOE), and standard diesel engines.

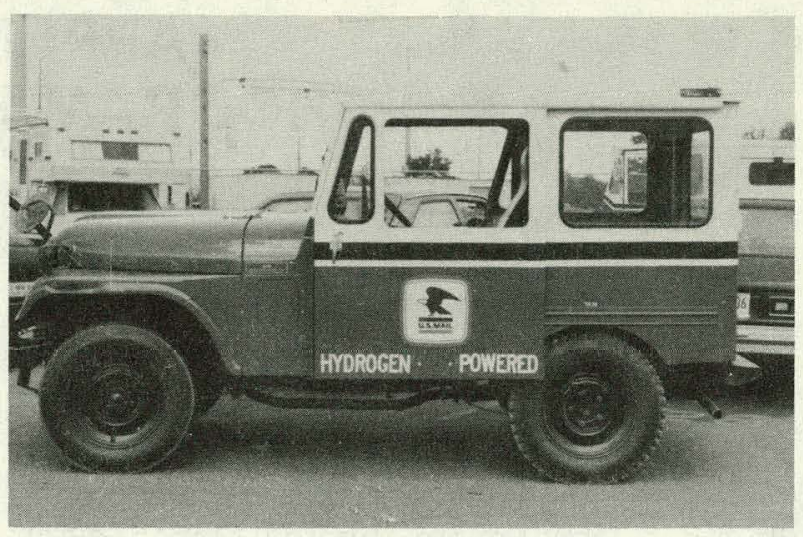

\section{Hydrogen Fueled Vehicles Are Being Tested} By The U.S. Postal Service

\section{Gasohol Tested in TVA Vehicles}

The Tennessee Valley Authority has begun a program to test the use of "gasohol" on TVA fleet operations. Approximately 170 vehicles serviced by the Golden Pond, Kentucky garage are now operating on gasohol for an approximate six month test period. TVA is also planning to expand the gasohol test to other select segments of operation. If the tests prove favorable from a conservation, maintenance, and economic standpint, gasohol may be used throughout TVA's fleet in the future.

\section{"Mothball" Savings Reported}

Several specific actions have been taken in the maintenance of the Reserve Flocts to im prove utilization efficiency. Although the exact amount of energy savings has not been measured, it is nonetheless believed significant.

The humidity level that is maintained in Reserve Fleet vessels in storage was allowed to increase from 25 percent to 35 percent. It was found that the higher humidity levels did not significantly impair the level of preservation of the ships. The amount of time which the dehumidifiers must operate has therefore been reduced, and the amount of electrical energy used has been reduced.

The electrical utility service for the fleet was changed to a time-of-day billing basis, and timers were installed so that equipment runs 
only during off-peak hours. By using electricity during off-peak hours, dollars can be saved by avoiding periods when the least efficient electrical generators are used by utilities.

\section{Modernizing Air/Ground Communications Facilities Will Reduce Energy Use}

Solid state equipment is presently being installed to replace older, tube-type equipment at enroute and air/ground communications facilities of the Federal Aviation Administration, which is part of the Department of Transportation. This new equipmlenl is energy efficient and requires less maintenance. In addition, the FAA has undertaken a test program to use batteries to provide emergency power with commercial power used to charge the batteries and for normal operations. Five facilities, all located in different parts of the country, have been selected to be tested for one year each. During the test, the HVAC system will be used only when a technician is at the site.

The expected system energy savings/year is as follows: Average electrical consumption = $60,000 \mathrm{kWh} /$ year. Total system $=535$ facilities. Total electrical consumption $=32,100,000$ $\mathrm{kWh} /$ year. Estimated energy consumption $=70$ percent less than with tube-type facilities. Savings $=22,470,000 \mathrm{kWh}$ per year.

\section{B. TRANSPORTATION PROGRAMS}

\section{Locomotive Energy Savings of 15 Percent Anticipated}

Fuel metering devices have been installed on 30 percent of the locomotives operating on the Alaska Railroad, DOT. Installation of these devices is expected to reduce locomotive fuel consumption by more than 15 percent. The remaining locomotives will be fitted with similar devices in the near future. As a result of these and other energy saving achievements, the Alaska Railroad was presented with a special award for contributions to energy savings in Alaska by the State of Alaska Department of Commerce and Economic Development.

\section{Procurement Procedures Ensure Efficient Vehicles}

The U.S. Department of the Interior has instituted procedures for the acquisition of fuel efficient motor vehicles. Each motor vehicle that is acquired is limited to the minimum body and engine size necessary to fulfill operational needs. To ensure that this is accomplished, annual forecasts of motor vehicle acquisitions have been developed, and all motor vehicle requisitions are now authorized by a single official in DOI. As a result, the fleet average of all sedans and passenger wagons (except law enforcement vehicles) acquired in FY 1978 was $20.2 \mathrm{mpg}$.

Supporting this policy, a motor vehicle study was conducted by the Bureau of Land Management within DOI to determine the size of vehicles needed to meet program requirements, and at the same time, be economical and energy efficient. The following are the results of the study:

Motor Vehicle Study

FY 1978 Vehicle Forecast (before Study)

$\begin{array}{cc}\text { Vehicle Type } & \text { Number } \\ 4 \times 4 \text { standard trucks } & 225 \\ 4 \times 2 \text { standard trucks } & \\ \text { Total } & 335\end{array}$

FY 1978 Vehicles Actually Ordered (after Study)

\begin{tabular}{cr} 
Vehicle Type & Number \\
\cline { 3 - 3 } $4 \times 4$ standard trucks & 27 \\
$4 \times 4$ compact trucks & 23 \\
$4 \times 2$ standard trucks & 0 \\
$4 \times 2$ compact trucks & 168 \\
Total & 218 \\
\hline
\end{tabular}




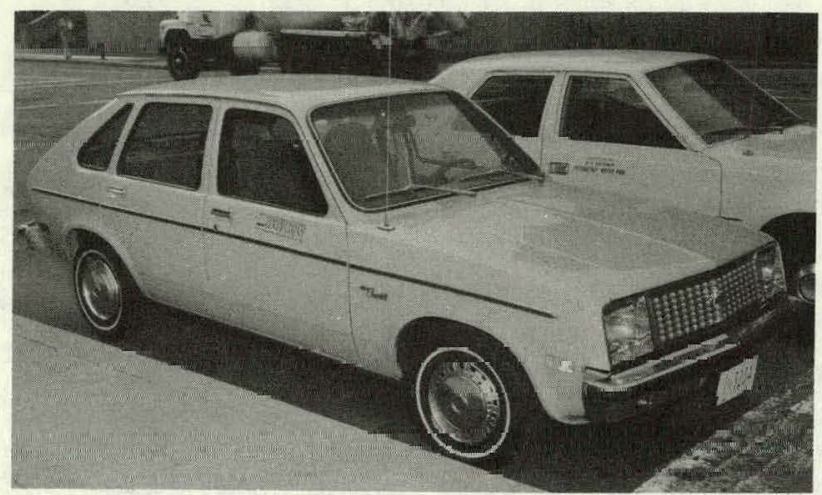

\section{Typical Small Vehicle Being Purchased Through G.S.A.}

The above data show that the total number of vehicles was reduced and also reflect a trend toward smaller sized and more energy efficient vehicles.

\section{DOE and DOI Demonstrate Electric Vehicles}

The Electric and Hybrid Vehicle Research, Development, and Demonstration Act of 1976 (P.L. 74-413 as amended) established the Federal Agency Electric and Hybrid Demonstrations. The goal is to reduce the quantity of imported petroleum used for vehicle transportation. The Department of Energy and the Department of the Interior have signed an Interagency Agreement which transferred $\$ 96,000$ to Interior to acquire eight electric vehicles. The electric vehicles that are to be purchased will satisfy the DOE Performance Standards. These vehicles will be tested at the following geographical locations: four vehicles in the Washington, D.C. area; one vehicle in Austwell, Texas; one vehicle in Denver, Colorado; one vehicle in Boulder City, Nevada; and one vehicle in Hardin, Montana.

\section{Driver Training Promotes Energy Conservation}

In another program to reduce the use of gasoline, the Department of Energy initiated a

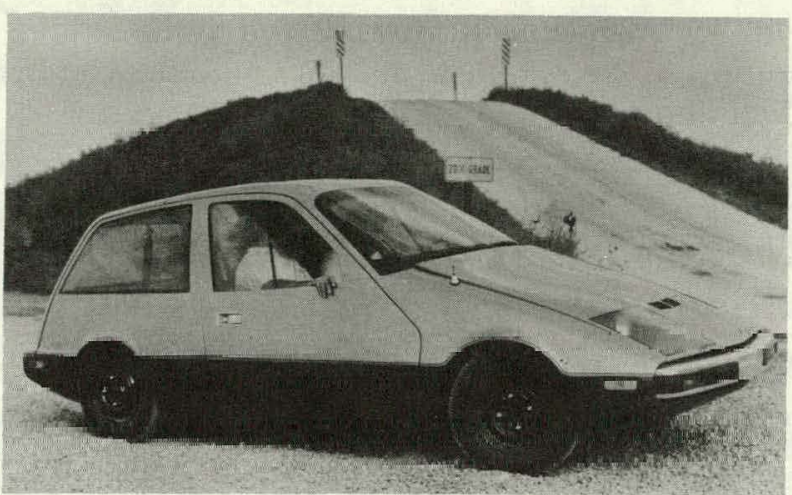

\section{Experimental Electric Vehicle}

Driver Energy Conservation Awareness Training Pilot Program at the Nevada Operations Office for the Division of Transportation Energy Conservation. If successful, this program will be expanded so that energy conservation awareness training can be provided to all federally licensed DOE vehicle operators and contractor personnel who operate government motor vehicles.

\section{TVA Tests Electric Vehicles with Utility Requirements}

In accordance with the national effort to reduce dependence upon foreign oil, Tennessee Valley Authority has also purchased six small electric vans and is now evaluating them. TVA is also participating in a two-year venture with the Electric Power Research Institute and several utilities to test and demonstrate the potential use of electric vehicles. Up to 20 electric vehicles will be purchased with EPRI funds and will be tested in various modes of use. In addition, TVA also plans to participate with the Department of Energy in an evaluation and demonstration of 20 advanced electric vehicles.

Data from the electric vehicle studies will be two-fold in scope. Initially, performance and maintenance data will be collected. Later, an assessment will be made of the implications of large-scale electric vehicle use upon power system generation and distribution. This dual approach will enable electric vehicle manufac- 
turers to build electric vehicles that will be compatible with utility requirements. TVA would like to have 1,000 electric vehicles in service in the TVA region by 1981.

\section{RESEARCH, INDUSTRIAL, AND UTILITIES \\ Electrical System Uses-Several Energy Sources}

A unique mixture of energy resources are integrated to provide the $64 \mathrm{MW}$ electrical demand of the Los Alamos Scientific Laboratory, operated by the Department of Energy. The electrical system includes $11 \mathrm{MW}$ of on-site cogeneration, $11 \mathrm{MW}$ of on-site conventional generation, 14.6 MW of hydrocapacity with limited supplementary fossil-energy, $15 \mathrm{MW}$ of hydropeaking capacity, and $21.5 \mathrm{MW}$ of time-ofday purchased capacity which is supplied by fossil fuel. On-site energy generation is integrated with purchased energy. What would otherwise be waste heat from the cogeneration units is used for space heating and for laboratory processes. Because the waste heat is used from the cogeneration units, the conversion ratio of this process is much more efficient than usual, producing electrical energy at a rate of approximately $7,000 \mathrm{Btu} / \mathrm{kWh}$ instead of the usual heat rate of $15,000 \mathrm{Btu} / \mathrm{kWh}$ for small generating units. Hydropower is scheduled to produce electricity during the peak load period to the maximum extent possible.

DOE officials compute that this mixture of utility resources at Los Alamos saves the Federal Government more than $\$ 5$ million annually. Efforts to learn more from this complex arrangement are continuing, so that additional methods for maximizing the use of local energy resources can be developed.

\section{TVA Uses Waste Heat}

One by-product of power plant operation is waste heat found in condenser cooling water. This warm water, resulting from a central power station's generation of steam, is produced in tremendous amounts and constitutes a large amount of unused energy.

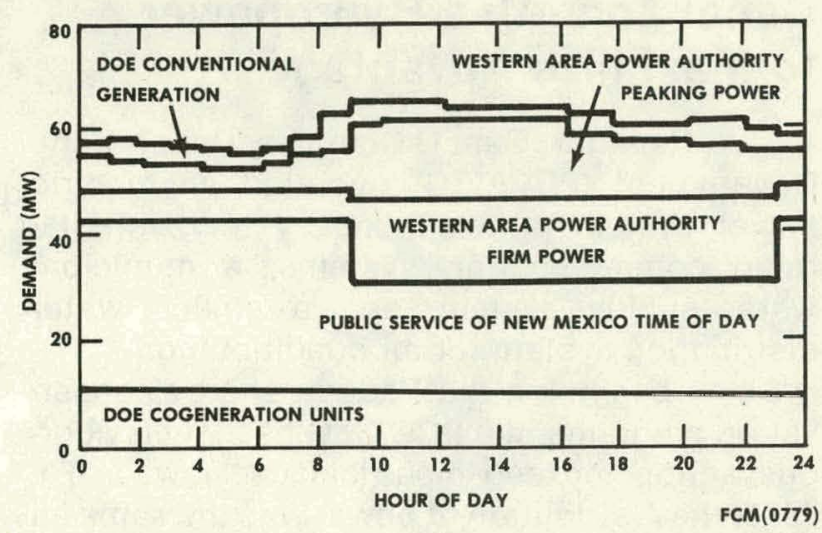

To investigate the potential commercial use of this low-grade waste heat, the Tennessee Valley Authority has operated a test waste heat greenhouse in Muscle Shoals, Alabama and has studied the idea of growing catfish in waste heat water from the Gallatin Steam Plant.

A greenhouse has also been constructed at the Brown Ferry Nuclear Plant, and a waste heat industrial park is now in the planning stages at the Watts Bar Nuclear Platn. TVA intends to examine the potential of using waste heat in all new generating facilities.

\section{Making Boilers More Efficient}

Heating and power generation for engineering and scientific research and development projects use large amounts of energy at the Department of Energy. Use of steam energy for heating, among other uses, is being reduced through improved boiler system efficiency. Practical steps to achieve this increased efficiency include (1) installing modular boiler systems comprising one or more smaller capacity boiler units which provide rapid response and reduce heat-up and cool-down losses due to their low thermal inertia; (2) modifying the boiler system to return steam condensate to the boiler to reduce the amount of make-up water required, hence, reduce energy needed to heat otherwise relatively cool makeup water; (3) preventing boiler water scale fuel use, and increase stack temperatures; (4) installing heat reclaiming economizers to recover heat from boiler flue gases and transfer it to entering feed water, in order to reduce fuel consumption; and (5) converting the boiler plant fuel source to a less critical preferred fuel. 


\section{Canal Zone Use Hydropower to Maximize Advantage}

The Panama Canal Company/Canal Zone Government (PCC/CZG) operated an electric power system, a telephone system, internal radio communication systems, a municipal water supply system, and a chilled water distribution system for air conditioning.

Since beginning the Federal energy conservation programs, the PCC/CZG has taken vigorous action to keep electrical use low. In FY 1978 , the distribution of power was the same as in FY 1977: 50 percent to military activities, 29 percent to the agency iteself, 16 percent to employee's quarters, and 5 percent to others (churches, clubs, commercial offices, etc.).

The PCC/CZG electric utility is interconnected with the contiguous system in the Republic of Panama. In addition to recurring maintenance outages, availability of water for PCC/CZG hydroelectric generating plants is the major determinant of how much of their power is bought from and sold to the Republic of Panama, and how much power must be generated from nonrenewable energy sources. These factors are highly variable from year to year and within years. FY 1976 was a wet year; PCC/CZG generated more hydroelectric power than in any other year since the plants were built. FY 1977 was dry; PCC/CZG generated less hydroelectric power than ever before.

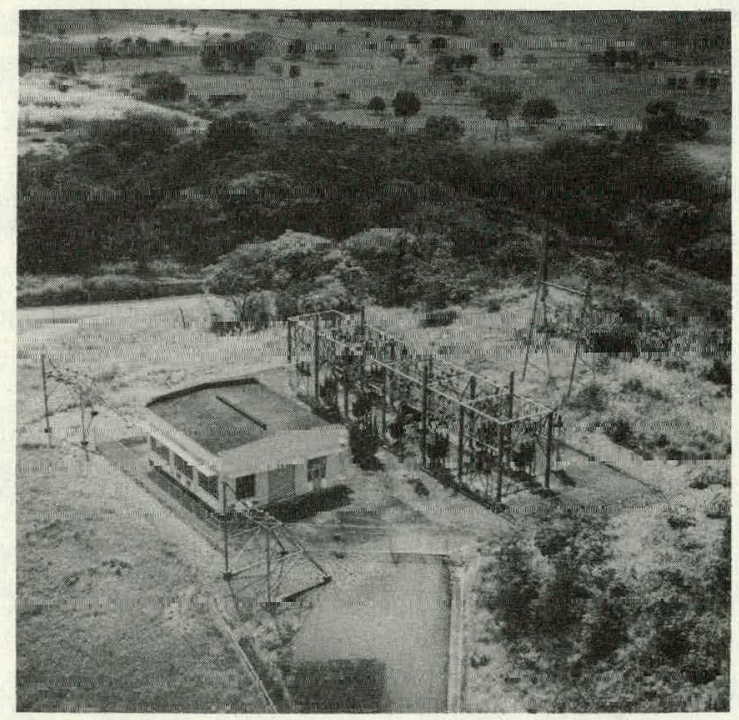

Electrical Substation and Transmission Lines
From FY 1975 to FY 1978, power usage in the Canal Zone was reduced 6.5 percent; power usage by its own stations varies with the mix of generation modes, but is down 25 percent since the beginning of the period.

\section{Fluidized-Bed Boilers Burn Coal Cleanly}

DOE is studying three of its sites that have good potential for burning coal in an atmospheric fluidized-bed boiler. In a fluidized-bed boiler, the combustion air passes upward through a grid or porous plate, which supports a thick (about 1 meter) bed a granular, noncombustible material, such as coal ash or lime. The combustion air fluidized this material and turbulently mixes it with pulverized coal, which is injected under low pressure. The heat release and heat transfer coefficients of a fluidized-bed boiler are high, drastically reducing the boiler size, weight, and cost. Coal-fired fluidized-bed boilers are more attractive than conventional coal-fired boilers with stack gas scrubbers because of their potential for improving net power generation efficiency and heat transfer rates, while lowering emission of sulfur oxides and trace metals, as well as eliminating problems associated with slagging and fouling.

\section{Innovative Technologies Used at Research Facilities}

Several innovative encrgy conservation techniqucs are being used at Department of Energy facilities, including:

- Modification of river water pump impellers at Savannah River, Suuth Carolina, to reduce required pump horsepower. Aimed specifically at reducing energy consumption at the Savannah Fiver I'lant, the size of the impellers in the river water pumps was reduced to lower the static pressure in llie puinus. The project cost $\$ 1.2$ million and is cxpected to save 129 billion Btu of electricity annually, or $\$ 311,000$.

- Currversiurr ul the Mó secondary particle beam line at Fermi National Accelerator Laboratory in Batavia, Illinois, from conventional magnets to superconducting magnets, to reduce energy use. 
- Implementation of 10 individual energy conservation activities in 11 buildings at the Mound Facility, Miamisburg, Ohio, to significantly reduce energy losses and heat losses in buildings. These activities include replacing fluorescienl ur mercuryvapor lighting with high-pressure sodium lighting or dummy tubes, separating hood exhausts to reduce air flow, installing twospeed ventilation fans, installing lighting timers or modifying lighting controls, and inslalliny smaller chillers at the power. housc to mect cooling requirements. DOE expects to invest $\$ 268,000$ in this multifaceted projest and to save 17.5 billion Btu, or $\$ 64,000$, annually.

- Modifications to the desiccant drying system at Sandia Laboratories, Albuquerque, New Mexico, has to reduce the site's elerstrical consumption. These modificaliums include using an outside air source instead of conditioned air, recovering waste heat from the process with a heat exchanger, and using existing automatic controls for the desiccant heating and cooling systems. The modifications will cost about $\$ 6,300$ and save 1.1 billion BTU, or $\$ 5,000$, annually.

\section{Geothermal Heating Investigated}

A geothermal test well, 10,000 feet deep, has been drilled at the site of the Idaho National Engineering Laboratory of the Department of Energy. The temperature of this resource is $320^{\circ} \mathrm{F}$ in commerical quantities, and it can be used to provide process heat for the waste chemical processing plant. An alternative use is space heating of the test reactor area, where only $150^{\circ} \mathrm{F}$ temperatures are required.

\section{Fuel Cells Being Assessed by TVA}

Using fuel without combustion, fuel cells resemble storage batteries that quietly produce energy with minimal environmental impacts. A variety of fuels such as petroleum distillates, natural gas, and converted coal by-products may be used as fuels for a fuel cell. For urban cogenerating applications, fuel cells may be

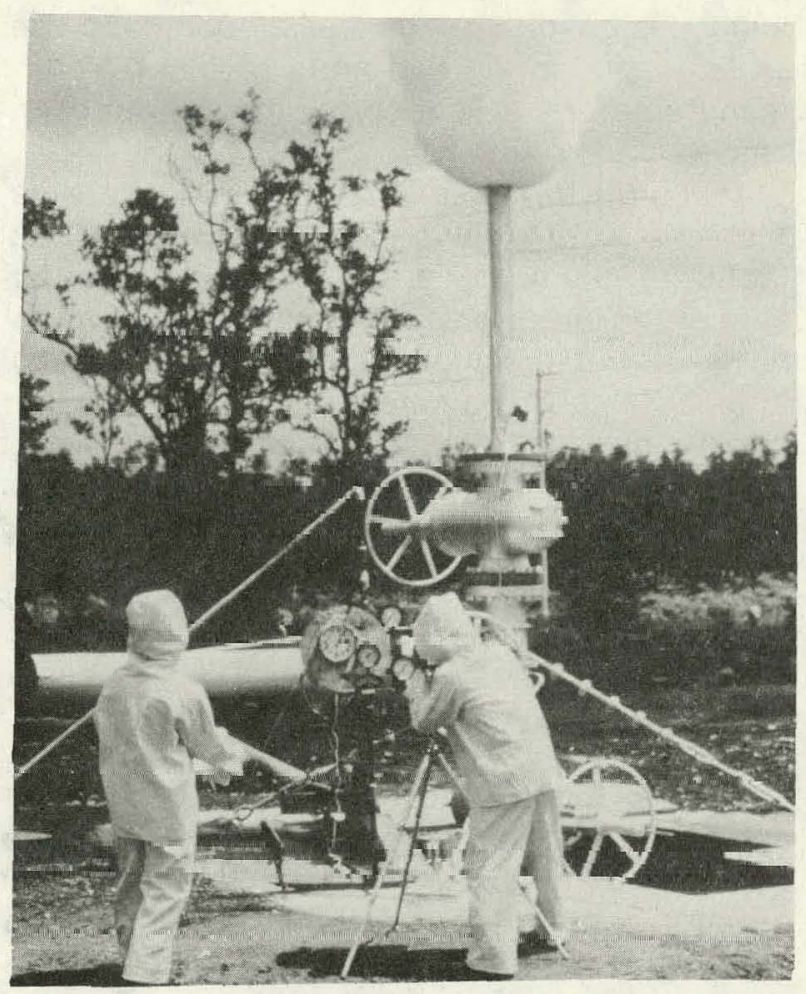

\section{Geothermal Test Well}

able to provide thermal and electrical energy at efficiencies as high as $50-70$ percent, which is significantly better than the $30-40$ percent efficiencies found in typical electrical generation systems.

It is these benefits that point to a potential application on the Tennessee Valley Authority system. A preliminary assessment of phosphoric and molten carbonate fuel cells using coalderived fuels has recently been completed. A coordinated program involving TVA, the Electric Power Research Institute, and the Department of Energy is being pursued to identify the costs and impacts of using coal-derived fuels with phosphoric acid fuel cells.

\section{Heat Pump Water Heater Tested}

This test project will evaluate the performance of 10 heat pump water heaters specif- 
ically designed to heat water for domestic use. DOE is sponsoring five units of two different manufacturers in cooperation with the Tennessee Valley Authority.

Test units have been installed in Russellville, Alabama, a TVA power distributor area. Manufacturing claims have suggested that 50 percent of the energy used for heating water might be saved with the heat pump water units. An additional benefit is a small amount of "free" air conditioning and dehumidification.

The approximate cost of the two year study is $\$ 5,000$ and runs from July 1979 , through June 1981.

\section{Electric Lighting and Power Improvements Cut Energy Use}

Electric lighting accounts for a significant portion of the total energy used in DOE office buildings and facilities. Electric lighting is also a major contributor to internal heat gain in a building, increasing the cooling load, and requiring additional air conditioning.

DOE began three retrofit projects in FY 1979 involving lighting modifications at Brookhaven National Laboratory, Upton, New York. Four projects-two involving installation of highpressure sodium lighting and two involving power utilization improvements-are planned. The lighting improvement projects are planned for Brookhaven National Laboratory, Upton, New York, and the Kansas City Plant, Kansas City, Missouri. The power utilization improvement projects are for the Los Alamos Scientific Laboratory Meson Accelerator, New Mexico,

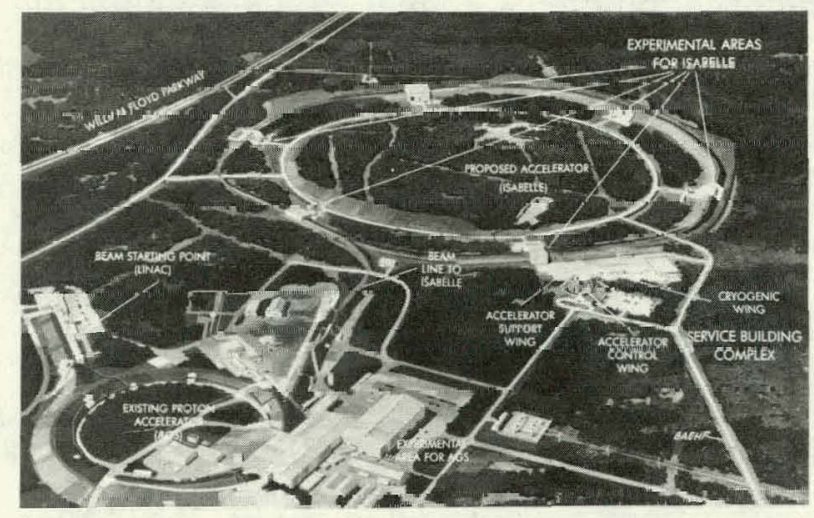

DOE Particle Accelerator and the Fermi National Accelerator Laboratory, Batavia, Illinois. DOE plans to invest almost $\$ 1.2$ million and save 40.5 billion Btu, or $\$ 261,000$, annually.

\section{Cogeneration Studied for Medical Complex}

Among the Department of Health, Education, and Welfare's facilities, the major energy consumer is the National Institutes of Health, which uses about 30 percent of the Department's total.

Under the project management of the Uttice of Facilities Engineering in the Office of the Secretary, HEW is studying the feasibility of a cogeneration plant at the NIH campus in Bethesda, Maryland. The nearby Navy installation comprising the National Naval Medical Center and the Uniformed Services University of Health Sciences is participating in the study to determine whether a joint cogeneration plant would prove economically justified. The preliminary feasibility assessment has been completed and shows such a plant to be cost-effective and promises large energy savings. Funds are now being sought for a full feasibility analysis and a conceptual design to detail the optimum system. With accelerated funding for the study, design, and construction, the plant could be in operation by late 1984 or early 1985 .

\section{BUILDINGS AND FACILITIES RETROFIT}

\section{Maximum Energy Savings Planned for Model Post Offices}

The U.S. Postal Service has designated five pusl uffices as models for energy conservation. Each postal region has selected an existing office from its gcographical area for the program. The offices range in slze from 127,000 to $1 / 6,000$ square feet and are located in Baton Rouge, LA; Lexington, KY; Paterson, NJ; Reno, NV; and Roanoke, VA. In addition, the Greensboro, NC, facility has been designated as the energy conservation model for the highly mechanized Bulk Mail Centers.

The objective of the program is to make each model post office a minimum energy user, serv- 
ing as a "target" for energy conservation within the regions. This is being done by performing a comprehensive site survey, thoroughly reviewing all operations, evaluating the building, and developing alternative energy saving proposals. Both Postal Service personnel and architect and engineering firms are performing the surveys and analyses.

Energy savings serve as an evaluation factor. Each project for a model office wlll be life cycle cost effective.

Energy metering and monitoring systems are boing established to provide baseline energy data to evaluate energy savings. These evaluations will also serve as the basis for recommending similar retrofit projects at other postal facilities throughout the country.

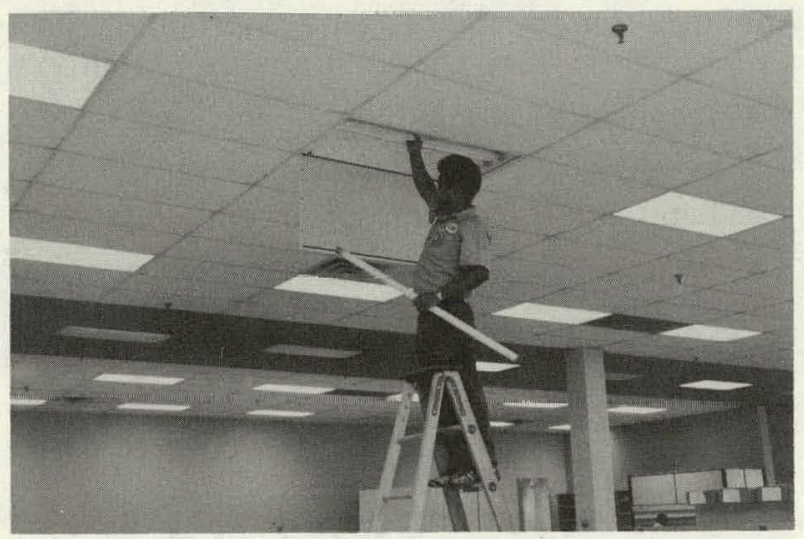

Lighting is being replaced in order to conserve energy at IRS Service Center.

\section{Dock Seals Reduce Energy Use}

Dock seals act as extensions to buildings and enclose the gap between the truck or boxcar door and the building's dock door. The dock seal may be foam or air filled, or may be constructed of rigid panels. The seal restricts the escape of heated air from inside the building during cold weather loading and unloading operations. The seal also protects the unloading and loading area from rain, ice, snow and blowing dirt, and improves safety and working conditions. Unauthorized access to the facility and to trucks or boxcars that are being loaded or unloaded is restricted.

The General Services Administration's Federal Supply Service has already installed dock seals at three facilities and others are planned. While the specific energy savings will be dependent on local weather conditions, the number of times the door is used in cold weather, and the cost of heating energy, indications are that the seals will pay for themselves within two to six years.

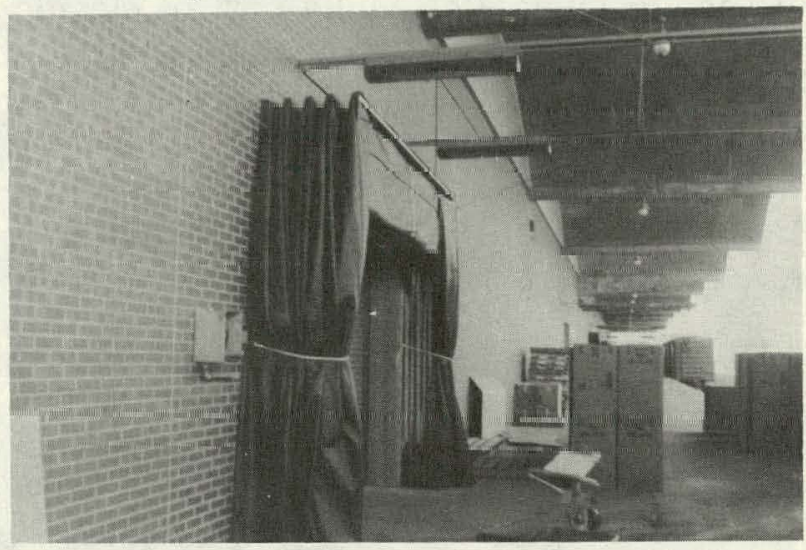

Above photograph shows installed dock seal at Federal Supply (FSS) storage facility in Denver, Colorado.

\section{Olympic Village Demonstration Project}

The Federal Correctional Institution at Lake Placid, New York, is being constructed to serve initially as the Olympic Village for the 1980 Winter Games. Following the games, the Olympic Village will be converted to a minimum security institution operated by the Bureau of Prisons. Each of the five dormitory-type structures will be equipped with a different energy storage system for comparative tests of space heating systems under similar conditions. Heat will be stored and released into living spaces as required, with electricity being provided at times that are best for the utility supplier.

The dormitories will demonstrate different heat storage, power demand reduction and control concepts. The heat storage devices that are being installed include ceramic bricks coupled with air handling units, water storage systems with air handlers, water storage with heat pumps, and concrete slab storage. To permit comparative sampling, one of the units will employ customary electric heating only, with no heat storage device. 
Installation of the research and monitoring equipment has already begun, and the test program will commence when the Winter Games' contestants occupy the buildings in January 1980. The tests will continue through 1982. This demonstration and testing program will provide data for the design of heat storage systems and devices to reduce the future cost of electric power generation and distribution equipment, with eventual advantages for all electric consumers.

\section{Energy Efficient Lights Require No Changes}

New Mercury vapor bulbs have been installed at the main gate of the U.S. Merchant Marine Academy at Kings Point, NY, which is operated by the Department of Commerce. No changes to the existing light fixtures were required for these new self-ballasted mercury lamps. All that was required was to unscrew the incandescent light fixture and screw in the self-ballasted mercury lamp. The mercury lamps provide three times the light of equal-wattage incandescent bulbs. An additional benefit of the mercury lamps is that they have a very long life. The greater area illuminated by the new mercury lights permitted the use of fewer light bulbs in the area.

\section{Solar Films Reduce Heat Gain}

In an attempt to reduce solar heat gain, a polyester film is being applied to the inside of windows in the kitchen, dining room, recreation room, and library of the United States Soldier's and Airmen's Home. The film forms a shield which reflects a portion of the sun's heat, glare, and untraviolet rays. Recording thermometers have been installed to monitor the "before" and "after" effects of the film. If test results are satisfactory, the film material will be installed on additional buildings, including the Home's hospital facility.

\section{Data Bank Contributes Toward Energy Savings}

The Veterans Administration's energy data bank continues to prove its value in the

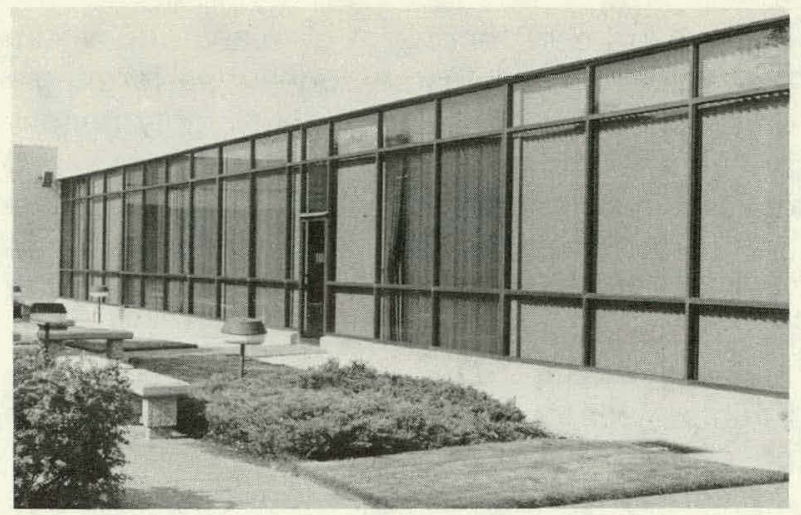

Solar film installed at Internal Revenue Service facilities reduces air conditioning re. quirements.

Agency's energy management program. The data bank includes for each hospital facility:

- Total energy consumed each quarter, by source

- Total square footage of all buildings

- Degree days experienced at each hospital location

- Dates of all construction additions

- Dates of all energy conservation retrofit projects

The data bank is being used in the analysis of retrofit project results and in the projection of energy costs and benefit for future applications. The data bank also permits the Energy Coordinators to maintain an accurate profile of energy use throughout the agency.

\section{Energy Saving Appliances Highlighted}

The General Services Administration's Federal Supply Service (FSS) has continued purchasing appliances for government use, using initial purchase price together with maintenance and other costs to arrive at the lowest total ownership cost to the government (Life Cycle Costing). During FY 1978, electric and gas ranges and water heaters which were purchased under this program should result in an estimated 500 billion Btu in lifetime energy savings and in an estimated $\$ 475,000$ in life cycle cost avoidance. Gas ranges are being procured 
that use an intermittent ignition system in lieu of the standing pilot light for ovens and surface burners. The FSS is also applying energy efficiency factors to the procurement of window air conditioners and household refrigerators, and is planning to include clothes dryers and dishwashers in future procurement programs.

\section{Energy Monitoring and Control Systems}

The Department of Energy is in the process of installing computerized energy management and control systems at several of its major installations. Energy monitoring and control systems (EMCS), or automated energy management systems, are computer systems for monitoring and controlling energy consuming equipment, such as heating, ventilating, and air conditioning (HVAC).

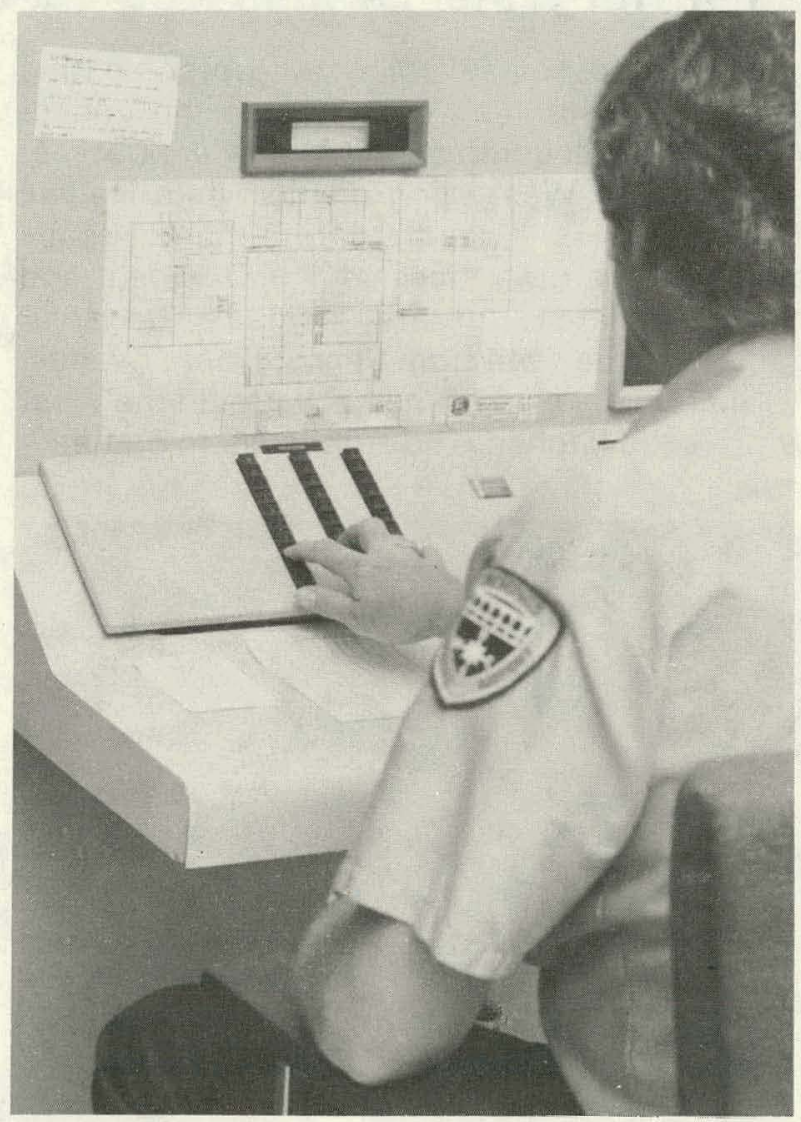

Building operators closely monitor building systems in order to ensure energy conservation.
EMCS provides constant surveillance of all energy systems in a buildings, a group of buildings, or an entire facility to provide the most efficient and effective use of energy and manpower possible. Typical functions are to:

- Monitor operating conditions of all systems and reschedule set points to optimize energy use

- Limit peak electrical demand values by predicting load trends and shedding nonessential services according to programmed priorities

- Optimize maintenance to maximize equipment life and minimize labor costs

- Monitor key system components to determine need for adjustment or replacement

- Monitor selected portions of any system and store the information in memory for later retrieval and analysis.

\section{Six Special Demonstration Parks}

A special initiative in energy conservation is being pursued by the National Park Service, U.S. Department of the Interior. The goal of the program is to "do it all in one year," do that dramatic and noteworthy energy use reductions can be obtained at six national parks. The six parks are: Independence National Historic Park, Grand Canyon National Park, Colonial National Historic Park, Shenandoah National Park, Fort Sumter National Monument, and Colorado National Monument.

In these six parks approximately $\$ 1.6$ million is being spend in FY 1979 to: (1) conduct energy surveys on all park buildings (approximately 390 buildings), (2) accomplish as estimated $\$ 1.3$ million in building retrofit projects, (3) conduct environmental education/interpretation programs for the public about the initiative and resultant energy savings, and (4) improve fleet vehicle management in these parks.

\section{Toward More Efficient New Buidings}

New Department of Energy buildings will be made almost twice as energy efficient as existing DOE structures by consolidating improved 


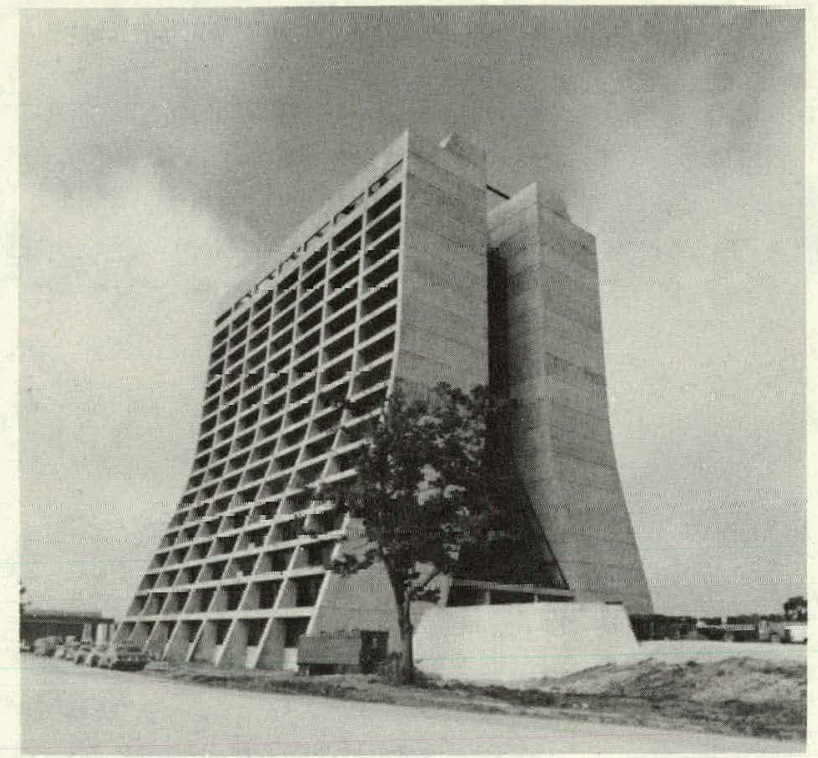

\section{New Building Designs Designed for Energy Efficiency}

energy performance design standards and by using new technologies. Among its activities to accomplish this goal, DOE is improving design criteria, using life cycle costing techniques that emphasize energy conservation, considering the use of solar and waste heat recovery systems, analyzing energy use through computer simulation, establishing "energy budgets," and preparing an energy conservation evaluation report for each building.

\section{Hospital Energy Standards Released}

The Veterans Administration completed, published, and distributed a new set of heating, ventilating, and air conditioning standards for hospitals. These standards substantially reduce outside air and ventilation requirements. Since 50-60 percent of a typical hospital's energy use is for heating, ventilating, and air conditioning, these standards should lead to major reductions in energy use.

\section{Geothermal Heat for Post Office Proposed}

A geothermal project at Klamath Falls, Oregon, involves the construction of a geother-
IIral heatlng system by the city for the purpse of serving 14 city, county, state, and Federal office buildings. When competed, the buildings connected to this system will use it for their primary heating energy source. The system design conccpt calls for drilling of a yeothermal well, piping the hut water to a centrally located heat exchanger, and then distributing mineral frec hot water frum the exchanger to client facilities. The U.S. Postal Service is actively participating in the planned project.

The postal facility involved is 47 years old, has 54,123 yross square feet, and is now heated by hot water using natural gas. The anticipated savings from conversion to geothermal is $\$ 2,000$ annually. Cost to the Postal Service will be determined by a flow meter and usage will be regulated by a control device.

\section{White House Uses Solar Hot Water System}

The White House solar hot water heating system, which was completed at the end of April 1979, is located on the roof of the Cabinet Room in the West Wing of the White House. The West Wing is separate from the residence and is where the offices of the President and his immediate staff are located. The solar panels can be seen from Pennsylvania Avenue.

The primary user of the hot water in the West Wing is the kitchen. The solar system preheats

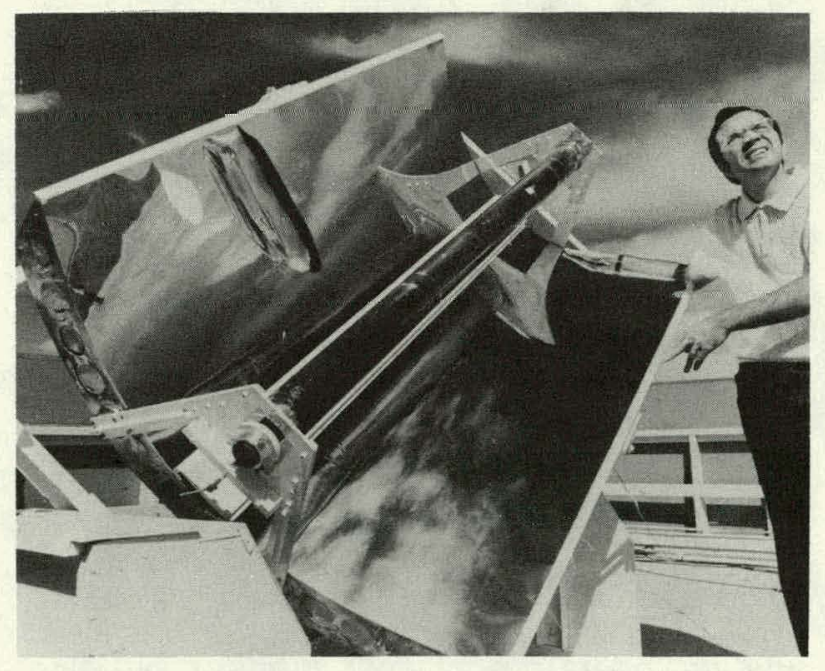

Solar Energy Collector 
water before it enters the regular hot water heater, thereby reducing the energy required. The system consists of 32 solar panels, each facing due south at a $33^{\circ}$ tilt, with a total collector area of 611 square feet. A storage tank holds 600 gallons of water. The heating fluid used to transfer energy from the collectors to the storage tank is ethylene glycol, which flows at the rate of 10 gallons per minute. System output is 75 to 130 million Btu/year. A back-up system using steam to produce hot water is available for days when there is insufficient solar radiation to meet hot water demands.

\section{Solar Energy Used in DOE}

In its in-house solar program, the Department of Energy is emphasizing hot water heating and space heatings. For retrofitting existing buildings, solar collector costs and efficiencies make hot water and space heating most attractive economically. Ten solar retrofit projects have been started in DOE facilities.

Twenty-five photovoltaic projects have been submitted for funding under the Federal photovoltaic program by the Bonneville Power Administration. Thirteen of these projects were approved and funded in April, 1979. Over 50 additional DOE solar photovoltaic projects are being considered. Five railroad crossings at Richland already use warning systems powered by photovoltaic cells.

\section{Solar Energy Supplements Greenhouse Heating}

With the rising costs of conventional fuels, it is becoming more important to investigate the ways in which solar energy can be utilized. An interesting project is being undertaken at the United States Soldiers' and Airmen's Home, in Washington, D.C., where solar energy will be used to provide supplemental winter heat for a greenhouse. Although solar energy usually provides most daytime heating in greenhouses, large amounts of fuel are burned in the night and on cloudy days. Alternative collection and storage techniques are being studied. The project is being engineered by the USSAH in conjuction with the Smithsonian Institution which operates the greenhouse.

\section{Federal Correctional Institution Employs Solar Energy}

The General Services Administration, in cooperation with the Bureau of Prisons, is presently completing construction at the Federal Correctional Institution, Bastrop, Texas, which will employ solar energy for space heating and cooling and for hot water. Approximately 23,000 square feet of solar collectors will be installed with a total storage capacity of 40,000 gallons. An automatic gravity drain is provided for freeze protection and reradiation losses.

The solar system is designed to provide 96.6 percent of the hot water needs, 45.5 percent of the heating, and 8.6 percent of the cooling needs for the entire institution. The conventional heating and cooling system will be maintained to provide back-up capability when required. A control system has been developed that will permit the solar system to delivery hot water, heating or cooling, based on both existing and anticipated loads. Also, solar preheated hot water will be provided to the hot water storage tank for the project.

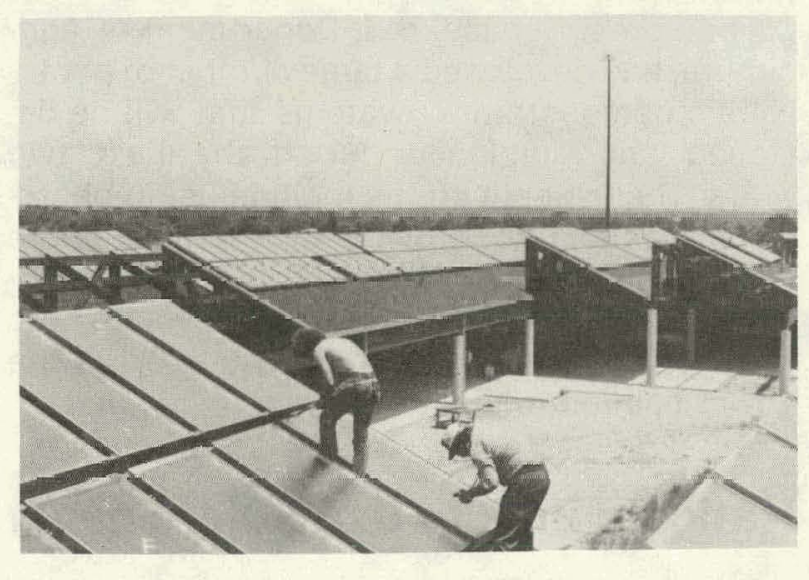

Solar Collectors Being Installed.

\section{Photovoltaic Systems Utilized by Forest Service and U.S. Air Force}

One of the prime advantages of solar voltaic systems is their ability to supply power without any need for utility connections. They are, 


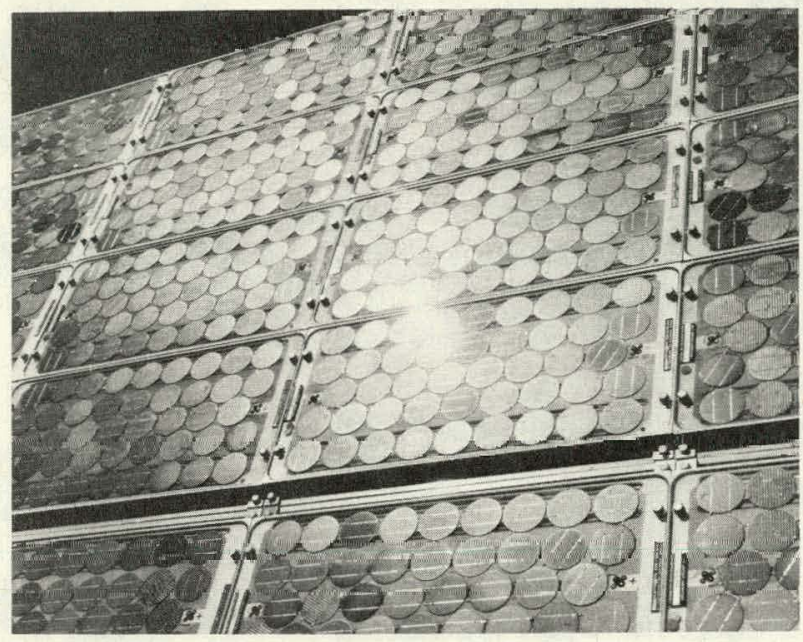

\section{Photovoltaic Systems Convert Sunlight Directly To Electricity.}

therefore, extremely useful for operations in remote areas where they can operate unattended for months at a time.

The Air Force has designed and constructed, in a joint program with $\mathrm{DOE}$, a $60 \mathrm{KW}$ photovoltaic electrical generating system at $\mathrm{Mt}$. Laguna Air Force Station, CA. This is the largest operating photovoltaic system in the world.

The Forest Service, U.S. Department of Agriculture, has developed a large number of photovoltaic demonstration systems that will be designed and emplaced during the next two years. These applications include using photovoltaic panels to provide power for remote forest lookout towers, to operate remote sensing instruments, to provide power for remote communications systems, and to provide the power needed to electrify livestock fencing.

\section{National Park to Use Solar Energy}

The Natural Bridges National Monument, Utah, of the National Park Service, DOI, is designing a 100 kilowatt peak solar photovoltaic (PV) electrical power generation system. The solar PV power system will service a variety of needs including water pumping, the ranger's residence, maintenance shops, and the visitor center. Electrical power is presently generated on-site with diesel generator units. Major elements comprising the PV system are the

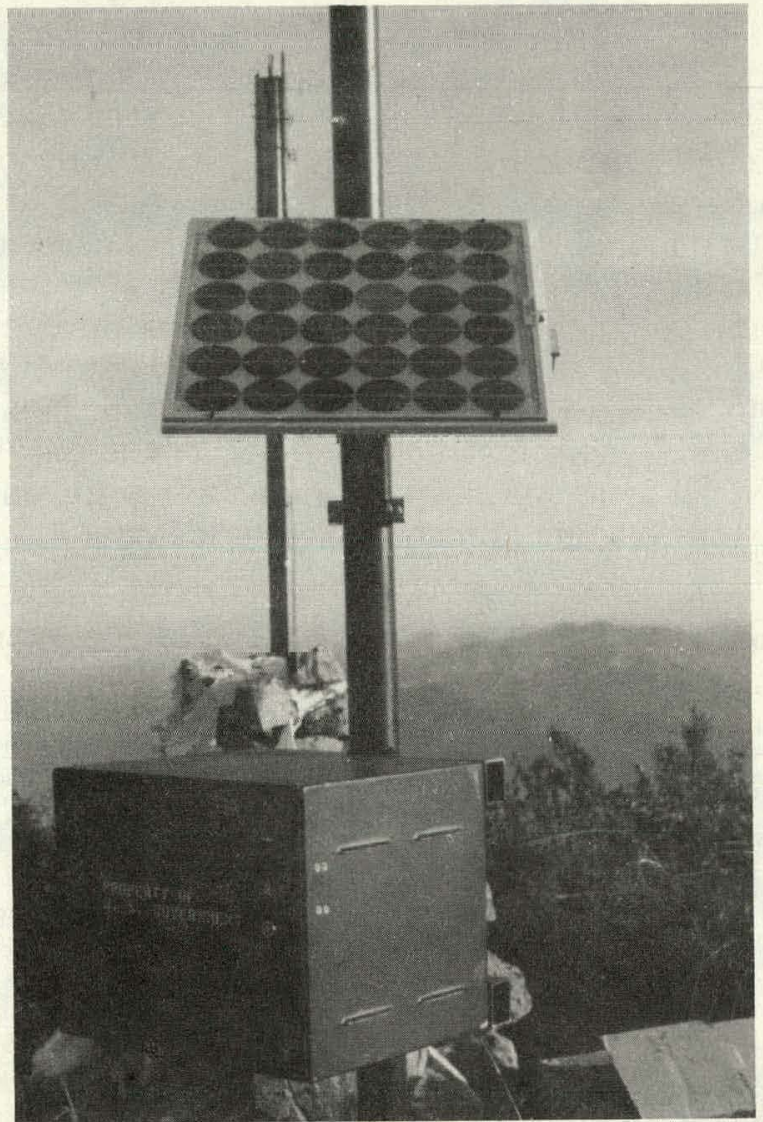

Photovoltaic energy systems high on remote mountain tops provide energy to run Customs Service transmitter utilized in law enforcement support activities.

photovoltaic array, storage batteries, and the back-up diesel generators. The system is capable of supplying nearly 100 percent of the electrical needs of Natural Bridges National Monument during periods of inclement weather.

\section{Photovoltaic System Powers Well Pump for Transportation Test Center}

At the Transportation Test Center of the Federal Railroad Administration, DOT, a reservoir is maintained in a remote part of the test site where utility services are not available. Currently in the design stage is a photovoltaic power system that will be used to power the 
pump and maintain the reservoir at the required level. This installation will eliminate regular visits to refill the reservoir by automatically maintaining the water level.

\section{Solar Powered Radio Repeaters Save Energy}

In August, 1977, the Technical Services Division of the U.S. Customs Service installed two solar energy systems on mountaintops in the southwest United States to determine the reliability and effectiveness of powering radio repeaters by solar energy rather than from bat- teries. Following almost two years of uninterrupted, failure-free performance, the solar power system is judged to be an unqualified success.

Normally the batteries at each site would be replaced three times a year using a helicopter to reach the mountaintops, at a total cost of over $\$ 8,000$ a year. With the cost of the solar system at $\$ 2,500$ per site, the savings to the U.S. Customs Service are estimated to be close to $\$ 37,000$ over the five-year lifetime of each installation. As a result of the success of this evaluation program, three additional solarpowered radio repeater systems are planned to be installed.

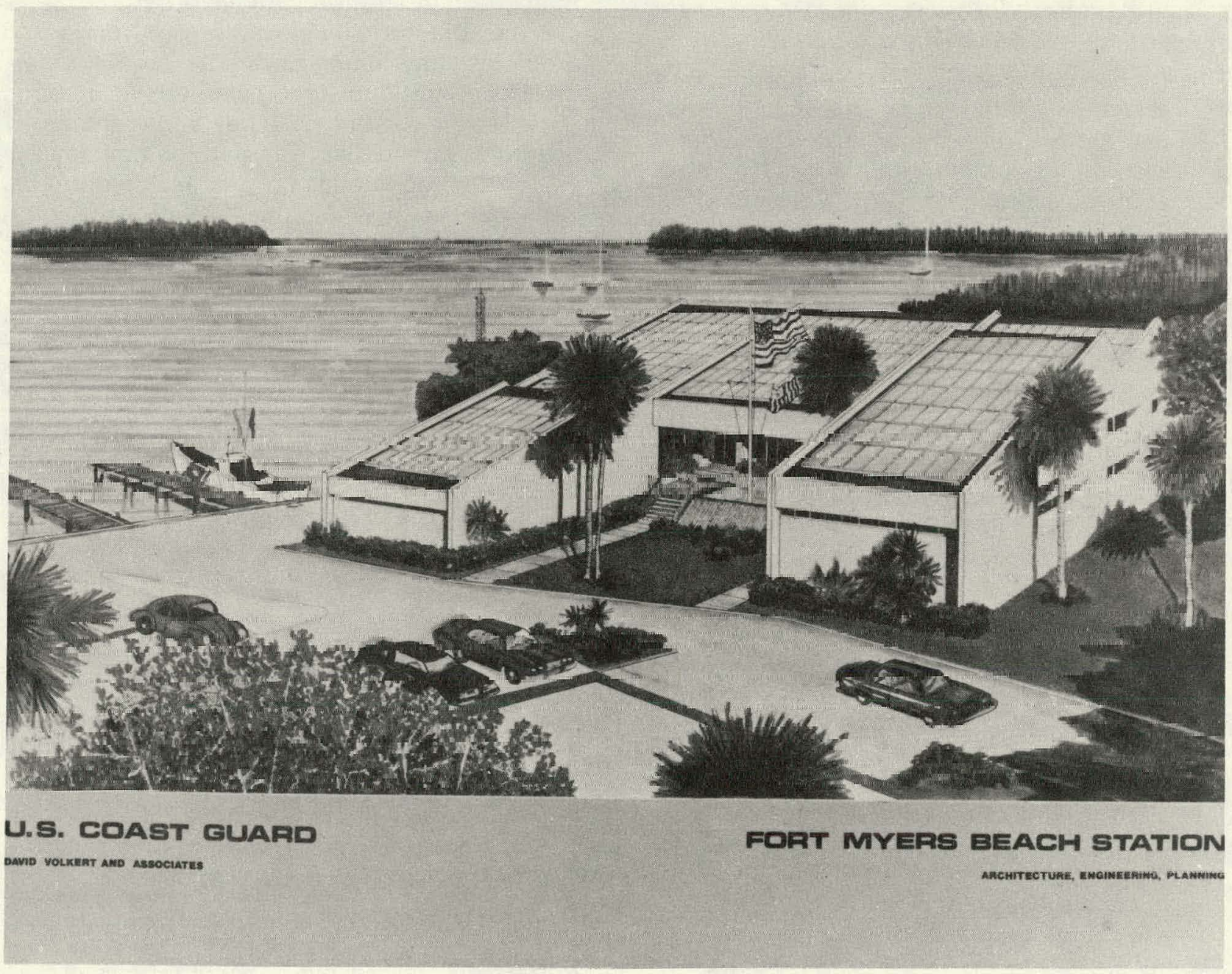

Proposed U.S. Coast Guard, Fort Myers Beach Station, Would Use Solar Energy 


\section{Solar Demonstration Projects at DOI}

During the past several years, the Department of the Interior has experimented with various new solar technologies. Numerous projects have evolved as a result of cooperative funding from DOE and/or other Federal agencies. The following are examples of projects which have been completed or are underway:

\section{Completed Solar Projects at DOI}

- Schuchuli Indian Village, Papago Reservation, Arizona-lighting 20 village homes and operating a domestic water pump, a washing machine and small unit electric refrigerators for food storage. Cost of the project was $\$ 193,000$ for a $3.5 \mathrm{~kW}$ capacity.

- Bighorn Canyon National Recreation Area, Wyoming-furnishing approximately 70 percent of the annual heating requirements and domestic hot water. The solar energy system for this project cost $\$ 96,000$.

- Carlsbad Caverns National Park, New Mexico-provides 70 percent of the annual heating and domestic hot water requirements. The system conserves an average of 425 gallons of fuel oil and 4,600 kilowatt hours of electricity annually.

- Mount Rushmore National Memorial, South Dakota-supplies 60 percent of the annual heating requirements and 15 tons of absorption cooling for the observatory.

\section{Solar Projects Underway at DOE}

- EROS Data Center, Sioux Falls, South Dakota-A project for adaption of solar energy to the existing domestic hot water heating system.

- High Plains Cooperative Program, Big Spring, Texas-A solar photovoltaic system to provide power for a network of portable meteorological monitoring stations at 25 sites is under construction.

- Ocmulgee National Monument, Georgia-A system is under design to retrofit a solar heating and cooling system to the existing visitor center.

- Yosemite National Park, California-A solar heating system consisting of flat plate fluid-type collectors, using circulating paraffin oil to heat water in a fiberglass storage tank, is under construction.

\section{F. RESOURCE RECOVERY Refuse/Steam Plant Solves Three Problems}

This innovative ettort stemmed from earller problems with local landfill disposal of refuse encountered by the Langley Research Center, operated by the National Aeronautics and Space Administration, Langley Air Force Base, and the adjacent City of Hampton, Virginia. The problems were: limited available landfill areas, aircraft operational problems caused by birds attracted to landfills, increasing community needs for refuse disposal, and the Langley Research Center's needs for process steam. As a consequence, a refuse-fired steam plant, jointly funded by the three parties, is to be build to provide a major portion of the Langley Research Center's steam needs and solve the refuse disposal problem. It is estimated that the operation of this plant will replace some 2.9 million gallons of oil annually. This 200 ton per day plant is scheduled to be operational about mid-1980.

\section{Cafeteria Heated by Burning Classified Waste}

In a joint program with the General Services Administration, the Department of State in Washington, D.C., is developing a heat recovery system for an incinerator used to burn classified waste. The recovered heat will be used to provide supplemental hot water and heating for the building's main cafeteria.

\section{Government Wastepaper Put to Good Use}

Wastepaper recycling benefits our overall energy supplies since it takes advantage of the 
energy content already present in paper being recycled. The use of recycled fibers rather than virgin fibers in the manufacture of paper products results in an energy savings of 16 million Btu per ton.

The General Services Administration arranges for the sale of government wastepaper in most large metropolitan areas of the U.S. The various grades of wastepaper are sorted, sometimes at the desk where they are produced, and collected and sold to the secondary fiber markets.

Since 1975, when the program began, GSA has sold a total of 122,500 tons of wastepaper, which has saved the nation almost two trillion Btu and resulted in the return of over four million dollars to the government.

\section{G. EMPLOYEE AWARENESS Energy Conservation Achieve- ments Recognized by the Navy}

Under the slogan Awareness Brings Conservation, the first annual Navy Department Energy Awareness Week was observed during October 23-27, 1978. An Energy Awareness Planning Booklel was dlstributed throughout the Navy and Marine Corps and information was disseminated to Navy Department personnel. Observation of Energy Awareness Week is planned in October of each year.

In addition, special awards were made to Navy and Marine Corps units for achievements in energy conservation and resource management:

- USS John F. Kennedy (CV 67) - Large Ships

- USS Blakely (FF 1072)-Small Ships

- Air Test and Evaluation Squadron, VX-1, Patuxnet River, Maryland-Aviation Squadron

- PMTC Point Mugu, California-Large Navy Shore Activities

- NAVSECGRUACT Winter Harbor, Maine-Small Navy Shore Activities

- Pearl Harbor Naval Shipyard, Pearl Harbor, Hawaii-Naval Industrial Facilities.

The winner in each category received a certificate of award, a distinctive plaque, and an of- ficial energy conservation flag to be flown over the activity for one year. Awards will be presented on an annual basis.

\section{Personnel Policies Help Conserve Energy}

In its efforts to promote energy conservation, the U.S. Coast Guard, DOT, has instituted several policies in the assignment of its personnel. A liberal approach is being used in granting tour extensions, and tour lengths ashore are stabilizing at three years, rather than two years. Consecutive assignments in the same geographic areas are being approved whenever practical and the distance individuals must travel when transferred is being minimized.

In addition, all personnel and family members receive energy conservation briefings before assignment to public quarters. If necessary, leases may be terminated if persistent energy abuse is found.

\section{Energy Awareness Training Develops Energy Conservation Leaders at USPS}

The U.S. Postal Service has established a cadre of Energy Conservation Instructors/Seminar Leaders. The leaders were trained by the Postal Service Training and Development Institute to conduct energy training seminars in each postal region.

Energy Coordinators at most buildings have received energy conservation training provided by regions and headquarters. The awareness program in each region varies in content; however, most Energy Coordinators have an awareness program specifically designed for their buildings. Energy conservation is discussed at safety talks, general meetings, or meetings specifically set aside for energy.

Regions have provided posters and energyrelated materials for distribution at postal facilities. In addition, some regions have been provided energy materials from utility companies and Federal, state, and local government agencies. 


\section{Making Sure of the Facts}

The Department of Transportation's Energy Conservation Coordinator makes site visits to various DOT facilities to assess the effectiveness of the energy conservation program. On these visits, the DOT coordinator talks with the local Energy Conservation Coordinators to see if there is an energy conservation awareness program, such as an adequate display of posters and other educational material. In addition, he or she makes spot checks to determine if thermostats are set as prescribed in the latest Executive Orders and, among other items, if illumination levels have been reduced. Objectives are to make sure that obvious conservation opportunities are not overlooked and to ensure that claimed energy savings are backed up by appropriate changes in operations.

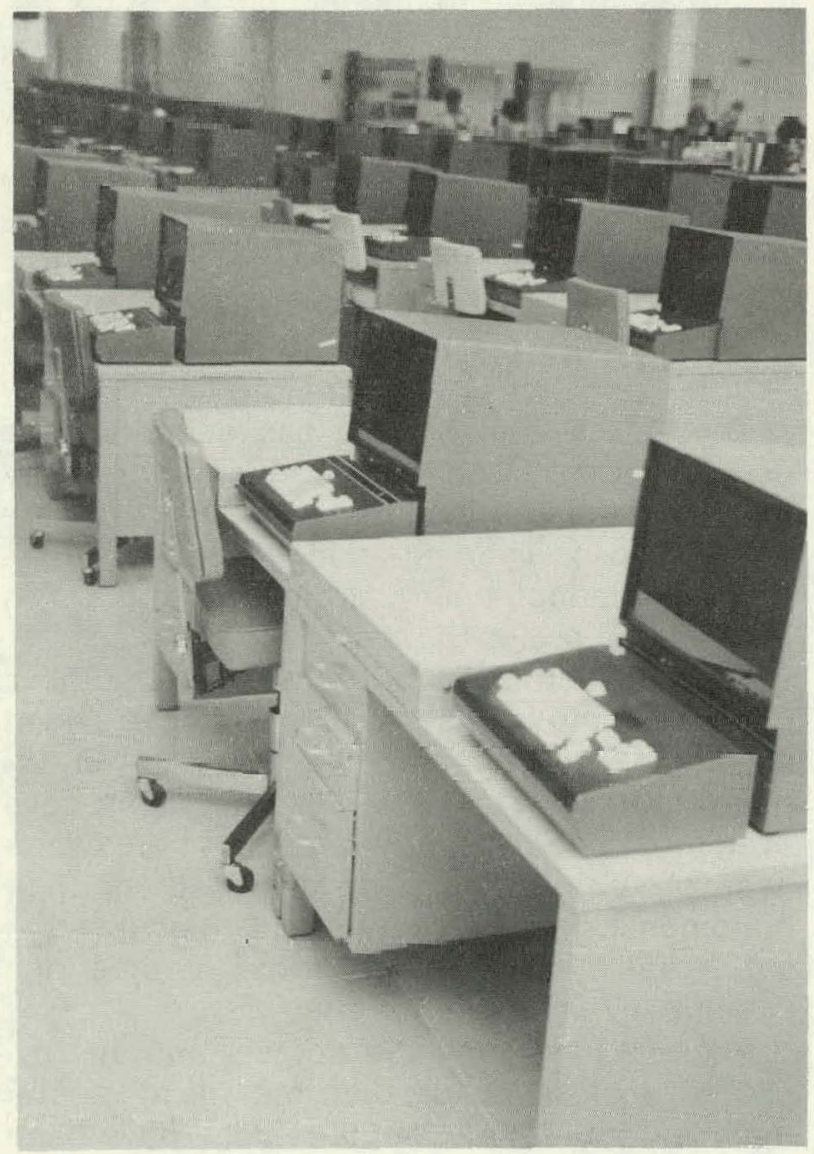

Terminals are turned off when not in operation.

\section{Energy Conservation Technology Training Helps VA Engineers}

Eight energy conservation workshops were conducted for Veterans Administration facility engineers. These sessions provided VA engineers with current energy conservation state of the art data. This training is supplemented with periodic information on new energy conservation developments. The training has also proven invaluable in the planning, funding, and installation of millions of dollars worth of cost effective energy conservation modifications to VA buildings.

Hlans have Just beell completcd for oight ad. ditional workshops for more detailed training and information on the current state of the art. Fundamentals of heating, ventilating, and air conditioning theory will also be presented. In

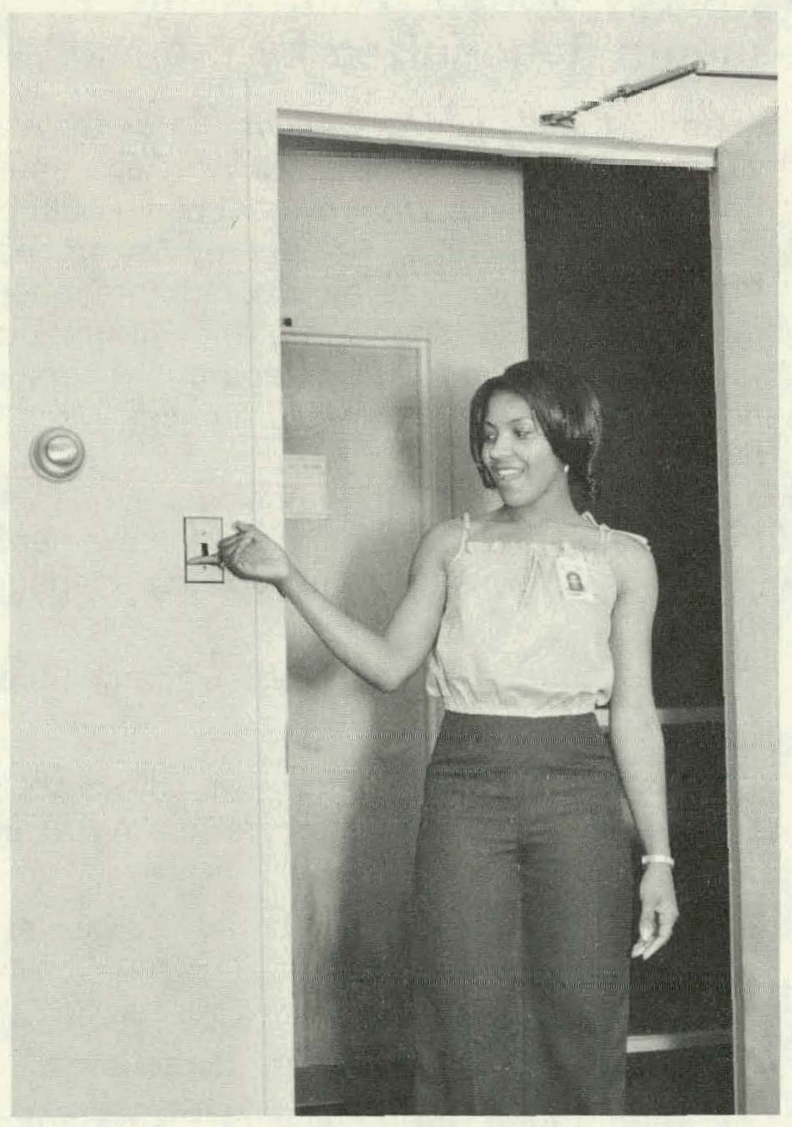

As part of the employee energy awareness program, employees turn off the lights when leaving the room. 
addition, it is planned to discuss methods of identifying, costing, and evaluating operation and maintenance procedures which have proven to be successful at other facilities.

\section{Energy Conservation Awareness Promoted at DOE}

As part of its in-house energy management program, the Department of Energy has an active employee energy awareness program to promote energy conservation among its civil service and contractor employees. A variety of techniques-newsletters, posters, films, lecturers, seminars, stickers, and decals, to name a few - have been used to disseminate information on energy conservation throughout DOE.

A pilot employee awareness program, started at DOE's Germantown, Maryland, installation in May 1979, includes six phases:

- Planning, to establish the organizational structure for planning, coordinating, controlling, and monitoring the program's progress

- Awareness, to introduce employees to the energy issue as it exists on a national level and at DOE

- Comprehension, to emphasize the individual's energy consumption habits and patterns, and the resulting personal responsibility to conserve

- Preference, to present individual options and ideas for conserving energy both at work and at home

- Intention, to link the energy conservation alternatives already presented with a desire to participate

- Behavior, to reinforce and encourage energy conservation behavior.

The Germantown pilot program, to be completed in September 1979, will be evaluated by monitoring employee participation and response during the program and be reviewing overall results after the program has been completed. Implementation of a program throughout DOE is expected to begin early in FY 1980.

\section{Energy Conservation Manuals Prepared}

The Veterans Administration has prepared two manuals to help its personnel find and evaluate energy conservation opportunities. The first, titled "Energy Mangement Tasks," was developed for inclusion in the reference book, "Energy Conservation in the VA." This publication is the result of selecting 22 energy conservation opportunities common to most VA medical centers. It provides step by step procedures for identification of opportunities, estimates of cost, and estimates of net energy savings.

In addition, the VA published the booklet, "Heating, Ventilating, and Air Conditioning Fundamentals." This booklet illustrates and explains in nontechnical terms: (1) the basic portions of all heating, ventilating, and air conditioning systems, (2) how and why changes in temperature, humidity, and air flow affect the human body, (3) illustrates how the basic components of system can be combined into various types of systems, and (4) provides a list of common problems and their correction.

\section{The Pink Panther Works to Save Energy}

During FY 1978, the Department of Energy received permission to print and distribute the Pink Panther series of energy conservation posters for FEMP. In addition, one million Pink Panther light switch decals were printed and distributed. FEMP plans to print a series of energy conservation posters and decals for distribution in FY 1980 to government agencies. The reproducible negatives of these materials will also be made available for use by states and local governments and the private sector.

DOE also has established a program with the Canadian Government energy office for the exchange of posters, decals, and energy conservation material. 

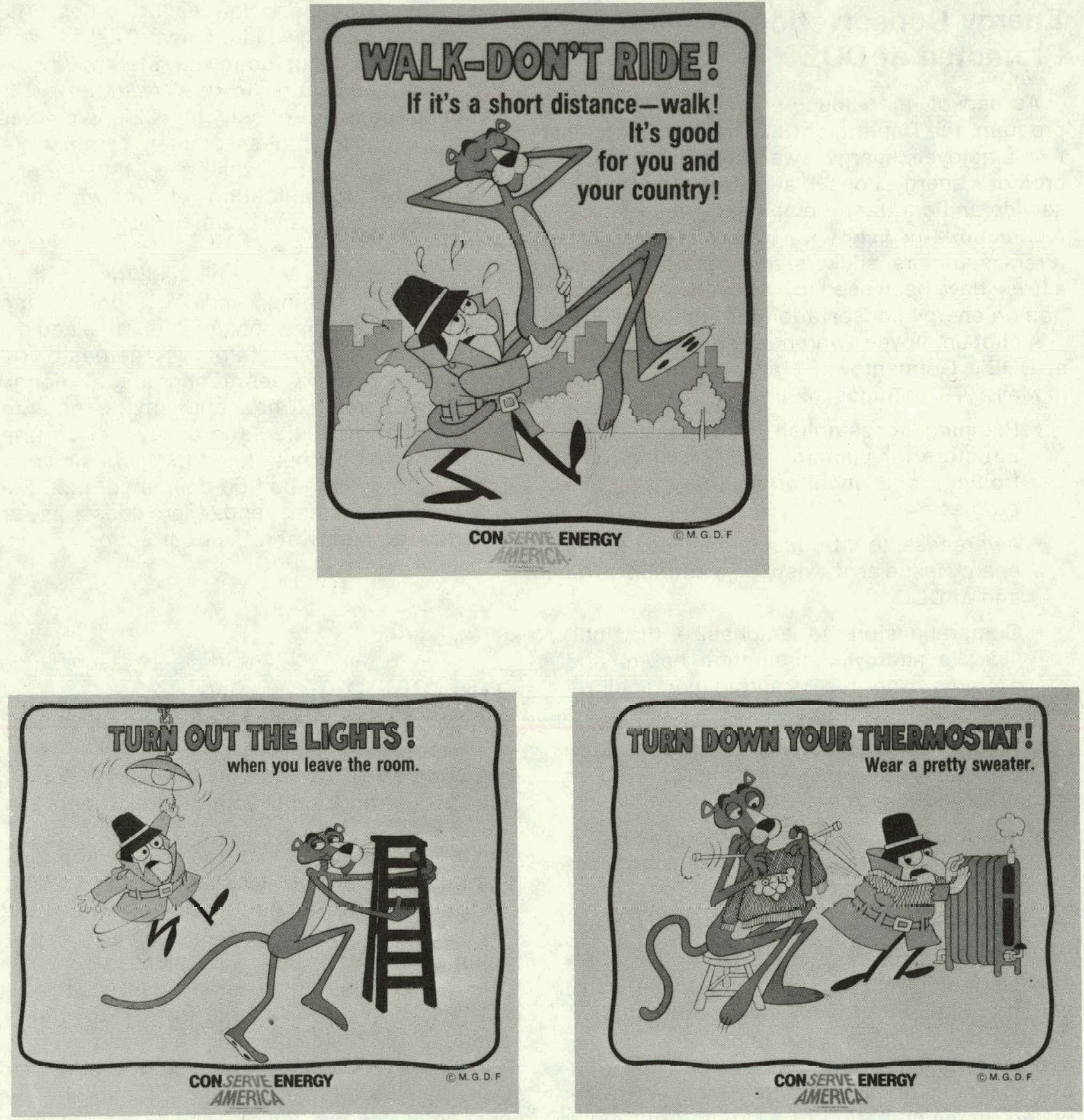

Pink Panther Posters Used by FEMP. 


\section{H. RELATED PROGRAMS \\ Water Conservation Saves Energy Too}

A reduction in the amount of water used in a building, particularly hot water, results in direct energy savings through reduced requirements for pumping and heating of water. The Federal Supply Service, General Services Administration, is now revising specifications for kitchen faucets and shower heads to include only those types that conserve water. While water conserving faucets and shower heads have been purchased in the past, this initiative will ensure that all future procurements will include water conservation requirements. In addition to energy cost savings, the program will also result in savings on water costs and sewage disposal costs.

\section{Procurement of Efficient ADP Equipment Energy}

Particular attention is now being focused on the procurement and use of Automatic Data Processing (ADP) equipment in the Treasury Department. Equipment that was procured in earlier years was often obsolete by commercial standards, but it provided a low cost per unit of work. In many cases, the equipment required special environmental controls, more space and more energy. In the past, space and energy costs were not major factors in the purchase decision when compared to the basic equipment cost.

As the price of energy has increased, the application of life cycle cost analyses now often justifies the purchase of new and more efficient equipment that requires less power to operate and reduces the demand on air conditioning systems.

In addition to these procurement considerations, the Department has also taken actions to reduce the energy use of its present equipment, such as ensuring that all terminals and related support equipment are turned off when not required for system operation support.

\section{Federal Prisoners Make Solar Collectors}

Federal Prison Industries is now producing solar collectors for sale to other government agencies. The collectors are manufactured at various Federal prisons, which are operated by the Bureau of Prisons of the Department of Justice. Both liquid flat plate collectors and hot air plate collectors are being produced.

The collectors have been tested in accordance with provisions of appropriate standards (ASHRAE 93-77 and DSET - SE2). Performance tests have been conducted on the collectors, with the instantaneous efficiency for the single glazed collector found to be 59.1 percent while that of the double glazed was found to be 54.5 percent when the inlet fluid temperature is equal to the ambient temperature.

A large order for the U.S. Navy is currently being produced by Federal Prison Industries.

\section{Energy Information Clearing- house Established at HEW}

The Energy and Education Action Center (EEAC), within the Office of Education of the Department of Health, Education, and Welfare, was established to act as a clearinghouse for schools and colleges with respect to Federal involvement in energy related activities. In general, the mission of the center is to promote all phases of energy related activities on an interagency basis by drawing on all relevant Federal, state and local resources to assist educational clientele in implementing energy plans.

The objectives of the EEAC are:

- To provide technical assistance and information to schools, postsecondary, and other educational institutions, in order to encourage and promote energy conservation in educational facilities

- To assist and encourage the development of adaption, identification, and dissemination of supplementary curricular materials in order to increase awareness and understanding of the multi-disciplinary nature of energy, environment, and engagement

- To encourage and support the in-service training of teachers, administrators, and 


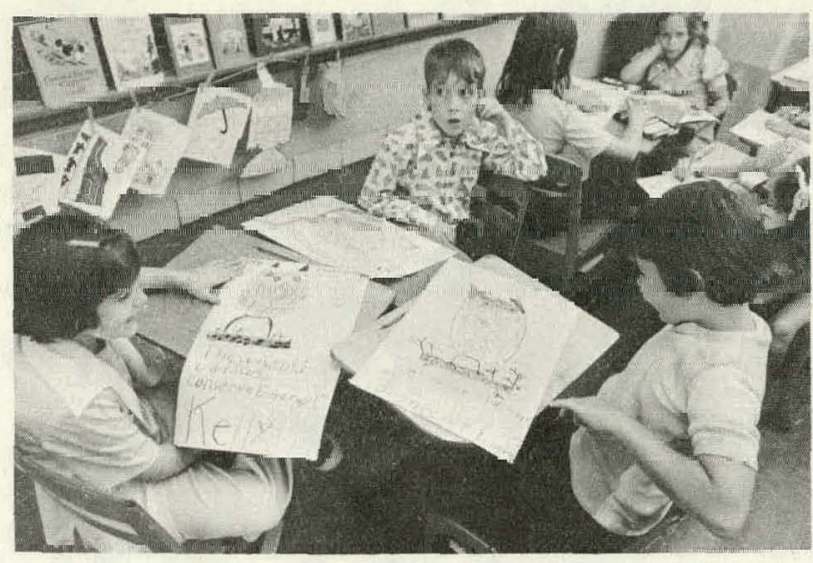

Energy Education/Consumer Publications: IVA Conducts Energy Conservation Program For Power Consumers of All Ages.

other members of the education community in areas dealing with energy awareness and understanding, conservation, environment, and engagement

- To identify and support programs in career and vocational education which address energy related employment opportunities.

\section{Airline's Energy Efficiency Increases with FAA's Help}

Efficiency of energy use is the focus for the Department of Transportation's Federal Aviation Administration and the aviation industry conservation program. Aviation fuel, particularly carrier fuel, is the predominant form of energy consumption for civil aviation. The conventional measure of the efficiency within the industry is "Revenue Ton-Miles Per Gallon," (RTM/G), where a revenue ton-mile is equivalent to one ton of revenue (paid passenger or cargo) traffic transported one mile.

The performance of RTM/G varied little between 1966 and 1971. A significant improvement in RTM/G began in 1972, which has continued through 1978, when there were 64.1 million more passenger enplanements and an increase of 13.8 percent in revenue ton-mile carried over 1973. The domestic air passenger and cargo airlines only used three percent more fuel and the RTM/G was about 35 percent higher than the 1973 level. Improved scheduling, higher luad factors, fewer air traffic delays, and improved flight planning were significant factors iil the improvement of energy efficiency.

\section{Van Pooling Program Set Up At Social Security Administration}

The Social Security Administration, HEW, has created and implemented the largest van pool program in the Federal Government. SSA headquarters now has 20 operational van pools and 40 more pools are awaiting delivery of vehicles.

\section{Energy Efficient Fertilizer Plants Developed by TVA and DOE}

The most important segment of the fertilizer industry is ammoniation-granulation plants. There are over 100 ammoniation-granulation plants throughout the United States and they produce 10 million tons of mixed fertilizer annually. Fertilizer production is a very energy intensive process which accounts for a significant portion of the load served by the Tennessee Valley Authority.

In 1976, the Department of Energy and TVA jointly undertook a project to reduce the energy requirements in the production of granual mixed fertilizers. The objective has been accomplished by TVA's development of a more energy efficient pipe-cross reactor.

A process study shows that the average fuel savings per ton of material produced in 433,334 Btu (90 percent of former consumption). This represents a savings in energy equivalent to $4,514,895$ gallons of fuel oil or about two million dollars per year. DOE funding for demonstration of this process was about $\$ 200,000$.

\section{Flywheel Energy Storage System Tested}

The Transportation Center of the Department of Transportation conducted a series of tests on R-32 and ACT I mass transit railroad cars to determine if the cars could use flywheel energy storage systems. While braking, electrical traction motors behave like generators, and can put energy into a spinning flywheel. When traction 


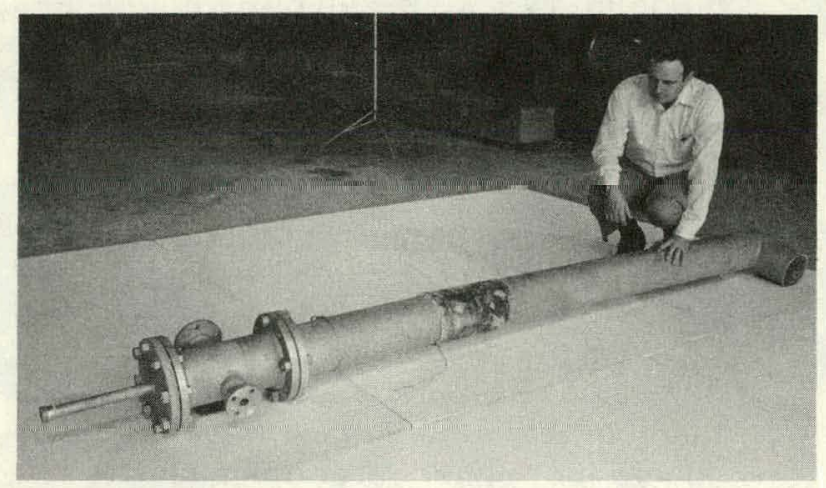

Fertilizer Ammoniated-Granulation: The PipeCrose Reactor (Above), Developed For The Fertilizer Industry's Ammoniation-Granulation Plants, Can Reduce By 90 Percent The Fuel Needed By The Plants To Produce A Ton Of Material.

motors are again required, the energy in the flywheel is fed back into the motors. Testing showed a greater energy savings in service runs with frequent etope than in long runs. The R-32 cars went into aclual revenue service in Now York City and realized savings of between 25 percent and 40 percent.

\section{Treasury Car Pooling Program}

The Treasury Car Pooling Program was established in 1974. Since then, the Department has continually supported the car pooling concept. Presently, the Department participates in two major car pooling projects under the auspices of the General Services Administration. As a result of these projects alone, Treasury is responsible for creating approximately 700 car pools which incorporate nearly 3,300 passengers. Additionally, priority is given to car pools when assigning internal or peripheral parking spaces for Treasury facilities.

Cognizant of the meaningful benefits derived from car pooling, Treasury has included the following services into its car pooling program: (1) a car pool commuter club which assists individuals who desire to form or join car pools by providing them with computer listings of those individuals with similar desires who live within reasonable proximity of their residences; and (2) a car pool locator map in the Main Treasury Buildings, which allows individuals to readily

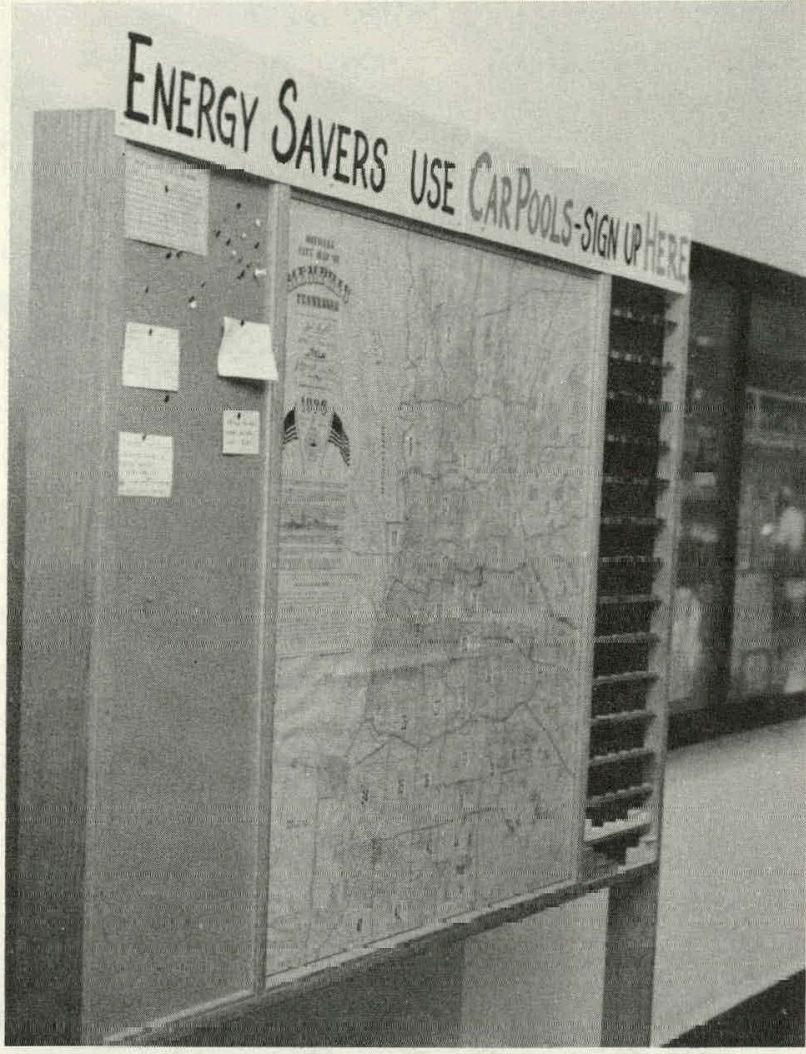

Carpool program at Memphis Center promotes energy conservation.

locate others desiring to become involved with car pools.

\section{Computer Models Help Find Ways to Increase Energy Efficiency}

The Federal Aviation Administration, Department of Transportation, is developing a fuel burn calculation method for analysis of specific airplane fuel consumption under any flight regime. This model will be available to investigate various fuel conservation methods applicable to airplane operations and in some instances will be useful for airplane configuration.

In addition, a national fuel consumption model is being constructed that considers historical demand and airplane fuel efficiency factors. Annual fuel consumption forecasts for alternative future fleet scenarios by type of airplane may be generated by this method. 


\section{TVA Promotes Energy Conservation}

The Tennessee Valley Authority is one of the nation's largest electrical utilities, and also one of the most progressive as far as energy conservation is concerned. It is pursuing a multifaceted program to help its customers reduce their energy use as well as to find practical alternatives to fossil fuels. Technical, as well as nontechnical innovation are hallmarks of the TVA program. New equipment and new applications of known technologies are being tried, as well as new ways of providing financing and leclunical assistance.

Some of TVA's more interesting projects include:

- Home Insulation Program-The Home Insulation Program, a cooperative effort between TVA and its 160 local power distributors, helps 2.4 million TVA residential consumers achieve energy conservation and the more efficient use of electricity through improved insulation and weatherization measures.

- The Super Saver Electric Home ProgramTVA is encouraging the building of super efficient homes that utilize proven conservation techniques-techniques such as maximum insulation, storm windows, and the electric heat pump. To promote the

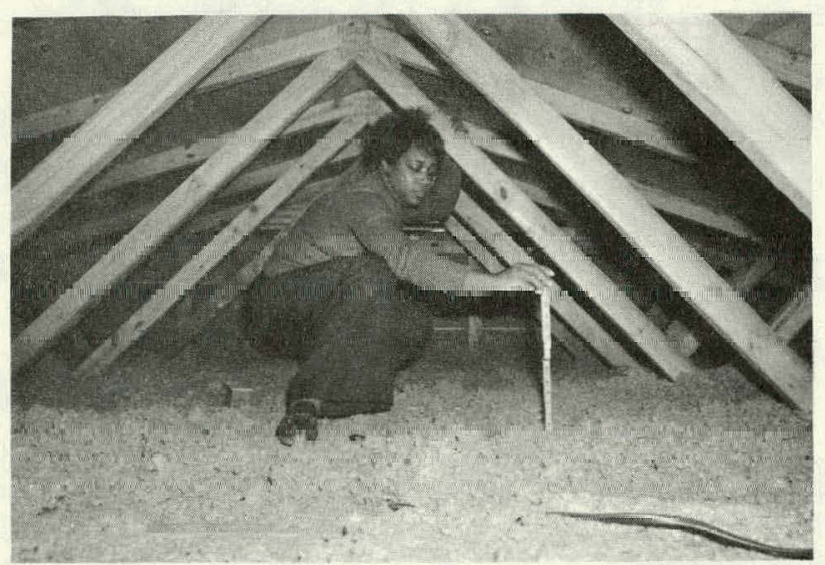

Home Insulation Program: Free Home Energy Audits Are Offered To The 2.4 Million Residential Consumers of TVA Power. The Audits Help The Consumer Identify Energy Conservation Opportunities. program, TVA works directly with builders and building associations and informs consumers of the benefits of owning an energy efficient home.

There are now more than 2,000 of these homes in the Valley. Each of these homes averages $65-75$ percent less heating and 25-35 percent less cooling than the typical home. Surveys indicate that Super Saver homes can be built for around $\$ 1,000$ more than conventional homes. A typical 1,800square foot Super Saver home results in a savings of about $\$ 340$ a year on the electric bill. This equates to a three year payback poriod. Since the additional mortgage cost would be about $\$ 136$, a new positive cash flow of $\$ 204$ per year results.

- Warm Room Project-The warm room demonstration project is a develonmental apprnach for providing warmth in homes too old or too large for practical insulation. As applied, one room of a home is insulated instead of insulating an entire home. The project seeks to develop a low cost warm room module that would be marketed commercially by a manufacturer.

- North Georgia Wood Heater Demonstration Project-TVA has begun a demonstration program offering loans to 1,000 customers of the North Georgia Electric Membership Cooperative (NGEMC) for the installation of modern, airtight wood-burning heaters in their electrically heated homes. The stoves, which must be selected from a TVA approved list and inspected after installation, are more efficient, more convenient, and safer than their antique counlerparts. It hos honn estimated that use of wood heaters can reduce the home's electrical heating requirement between 60 and 80 percent.

- Commercial and Industrial Encrgy Audit Program-On request, the $285,000 \mathrm{com}$ mercial and industrial users of TVA power may receive energy audits and loans to help eliminate energy waste. TVA engineers and consulting engineers conduct the surveys in this cooperative effort between TVA and local power distributors. 
- The Certified Electric Heat Pump Installation Program-The Certified Electric Heat Pump Installation Program seeks to assist in the public acceptance and implementation of this highly efficient machine by helping to eliminate three problems that have damaged its reputation in the pastfaulty units, poor installations, and inade- quate servicing. Financing is available for certified installation in existing homes through the Home Insulation Program. Through the estimated 129,000 heat pumps installed in the power service area as of June 30, 1978, approximately 551 million $\mathrm{kWh}$ is being saved each year. 
THIS PAGE

\section{WAS INTENTIONALLY LEFT BLANK}




\section{APPENDIX B SUMMARIES OF AGENCY ENERGY CONSERVATION REPORTS}

DIRECTORY FOR LARGE ENERGY USING AGENCIES

AGENCY
Department of Defense
Department of Energy
United States Postal Service
General Services Administration
Veterans Administration
Department of Transportation
National Aeronautics and
Space Administration
Department of the Interior
Department of Agriculture

PAGE

Department of Health, Education, and Welfare 74

- Department of Energy

64

65

Department of Justice

Department of the Treasury

Department of Commerce $\quad 76$

Panama Canal Company/

.69 Canal Zone Government 77

70 Department of Labor 78

Tennessee Valley Authority 78

71 Environmental Protection Agency 79

72 Department of Housing and

73 Urban Development 


\section{DEPARTMENT OF DEFENSE}

The Department of Defense (DOD) is responsible for providing the military force needed to deter war and protect the security of the United States and its military allies. The major elements of these forces are the Army, Navy, Air Force, and Marine Corps. In order to perform this function, the DOD maintains military forces and installations on a worldwide basis. The force consists of approximately 3,100,000 military and civilian employees occupying 395,000 buildings, totalling more than 2.4 billion square feet of floorspace.

The DOD energy management program is a major element of the overall Federal Energy Management Program to reduce the Federal Government's energy consumption. DOD's leadership in this Federal effort has clearly been demonstrated since energy reduction goals were firet established in FY 1974. This leadership was again demonstrated in FY 1978 when DOD's total energy consumption was $104.0 \times 10^{12}$ Btu (7.1 percent) below the base year FY 1975.

In the management of its energy program, the DOD establishes broad general policy guidance and goals which are contained in a series of Defense Energy Program Policy Memoranda. The military departments and defense agencies in turn develop specific goals, actions and programs to implement this guidance. Details of these goals, programs and accomplishments are contained in the military department energy plans and annual reports.

The DOD continued to seek to reduce energy consumption of the mobility forces and at the same tıme assure that the training, readiness and combat capability of the strategic and tactical forces is not impaired. The programs to meet this objective have been successful. Energy awareness indoctrination and education in troop and personnel training programs, the use of aircraft, ship and vehicle simulators, as well as programs to recognize and reward energy consumption efforts and achievements, are key elements to the elimination of unnecessary mobility related energy consumption.

A highlight of DOD's energy awareness activities was the first military department-wide energy awareness week which the Department of the Navy sponsored in October, 1978. During the Navy Department energy awareness week, seven energy conservation awards were presented to Navy and Marine Corps units and activities selected from a group of 52 Navy and eight Marine Corps activities.

DOD continues its energy conservation retrofit projects in the 1.5 billion dollar multi-year energy conservation investment program (ECIP) to achieve energy reduction in installation energy use and to improve routine operation and maintenance programs of the facilities. Since the ECIP's inception in FY 1976, energy conservation retrofit projects at existing DOD facilities have significantly reduced that energy required to heat, cool and provlde industrial support to installations. A similar program, the energy conservation and management program (ECAM), was initiated for energy conservation retrofit programs in government-owned, contractor-operated industrial facilities. ECIP and ECAM are the cornerstones of the long range DOD effort to reduce the use of utility energy in our installations.

The priorities for DOD's energy program are described in four bands of action. The first level of their defense energy priorities is to establish mechanisms to assure the supply of mobility fuels for our military forces. The second level of priority is to develop a research and development program plan to provide for improved energy efficiency and eventual transition to alternate fuels. Their third priority is to develop a series of energy initiatives to be executed jointly with the Department of Energy. Their fourth priority includes all actions needed to conserve facilities energy and reduce peak usage. These actions were placed in level IV and not higher, not because they are unimportant. Instead, they have been and are so important that they have already devoted much time and attention to them.

The DOD priorities for 1980 cover:

- Energy supply assurance to identify and take those supply and procurement actions that will make DOD less vulnerable to supply disruption and to complete the policy and regulatory initiatives begun in 1979 , to provide prompt priority allocation to DOD of energy supplies during periods of disruption. 
- Energy conservation to improve visibility over the entire DOD energy conservation program.'This priority requires quantum improvements in the data base, timeliness and accuracy of reporting, development of measures of energy efficiency, measurement of progress against conservation goals, and the correlation of conservation expenditures and performance. Energy con servation incentives will also be created to motivate DOD personnel at all levels to improve conservation performance.

- Energy technology to focus on mobility fuel usage as a result of possible impacts of proposed energy legislation which the Congress may pass. DOD plans to bring the initiatives from the 1979 priority group III from the planning mode to implementation. Special emphasis will be placed on three showcase installations of energy technology demonstration. DOD also plans to strengthen the lead service management structure for energy technology.

\section{DEPARTMENT OF ENERGY}

The Department of Energy - the nation's leader in energy related activities-coordinates national energy policy by performing in a policy-making, regulatory, and informational role, as well as conducting research and development on ways to use existing energy sources more effectively. Discovering and developing new forms of energy; performing research in particle, physical, and other basic sciences; and producing nuclear materials used as fuel for nuclear power plants as well as for defense are also part of DOE's mission. These activities are carried out at a variety of facilities-more than 7,000 structures at 80 different sitesmany of which are highly energy intensive.

To promote the efficient and economical use of energy in its facilities, DOE has developed an in-house energy management program, encompassing energy conservation in buildings and general operations. The program is the responsibility of the Director of Administration, who reports directly to the Office of the Secretary. The Director of Administration has designated the Director, Office of Construction and Facility Management, as the DOE Energy
Conservation Coordinator, with the Director, Division of Procurement, responsible for im. plementing the motor vehicle and mobile equip. ment aspects of the Department's program. Im. plementation of the program at field sites is the responsibility of energy management coordinators, guided by the Energy Conservation Coordinator.

The Department's major energy goals-in conformation with legislation and presidential orders-include energy consumption reduction of five percent in existing buildings by April 1, 1980 , a total of 20 percent in existing buildings by the end of FY 1985, and 45 percent in new buildings by the end of FY 1985, as compared to FY 1975. Elimination of the use of natural gas and petroleum in major fuel burning installa. tions by FY 1985 is another important in-house energy management goal.

DOE expects to meet 90 percent of its FY 1985 goal through an extensive retrofit investment program; the remaining 10 percent will be met through a variety of operational and maintenance improvements in its buildings and general operations, as well as an energy conserva. tion awareness program. Use of emerging technologies, such as solar and coal-oil mixtures, is not expected to contribute significantly to the 1985 goal, but will be important in the long term.

DOE's retrofit projects for'buildings and operational processes vary widely, but fall into six general categories:

- Energy monitoring and control systems

- Heating, ventilating, and air conditioning

- Mechanical equipment and boilers

- Electric lighting and power improvements

- Building insulation and storm windows

- Innovative and advanced technology.

A total of 292 retrofit projects costing $\$ 75.6$ million have been funded or proposed to Congress from FY 1977 through FY 1980. By the end of FY 1980, DOE will have initiated projects at half of its more than 80 sites. Savings from the individual projects are realized about a year after the respective program budgets are ap. proved due to design and construction leadtime requirements. In addition to retrofit projects, DOE's buildings program includes: 
- Surveys to identify the most cost effective ways to save energy in existing buildings and processes.

- Operational and maintenance improvements in existing buildings, processes, and equipment, such as reducing lighting levels, lowering thermostats in the heating season, or rescheduling janitorial services to daylight hours.

- Program to consolidate energy performance design standards and use emerging technologies in new buildings so that these structures will be twice as energy efficient as existing DOE structures. Among its activities in this program, DOE is im. proving design criteria, using life cycle costing techniques that emphasize energy conservation, and analyzing energy use through computer simulation.

- Metering program to allow measurement of the amount of energy being used in buildings versus that being used in experimental and production processes, as well as the actual savings realized in retrofit and other energy conservation projects.

Also as part of its buildings program, DOE plans to demonstrate emerging technologies. The use of solar energy for hot water and for space heating is being emphasized; technologies such as the use of waste fuels, geothermal energy, coal-oil mixtures, and fluidized-bed coal boilers are also being considered.

DOE's general operations program includes transportation, employee awareness, surveys of processes for efficiency improvements, and central plant fuel conversions. Energy conservation activities in the Department's transportation program focus on acquiring new vehicles that are more fuel efficient. Driver energy conservation awareness training, pooling of vehicles, improved maintenance schedules, utilization of bus services, and enforcement of the national speed limit are other ways DOE is conserving transportation energy.

Efforts to conserve energy in its highly energy intensive experimental and production processes primarily involve detailed engineering surveys of the major buildings, utility systems, and related processes to identify ways to achieve the most energy efficient operations without adversely affecting research, development, and production goals. An example is a $\$ 3$ million study on potential uses of the nearly 400 trillion Btu of waste heat rejected annually be the gaseous diffusion plants and by the reactors at Savannah River.

To reduce its dependence on fuel oil and eliminate its use of natural gas by 1995, DOE plans an investment program to convert its major central heating plants to coal and renewable resources. By mid 1979, those facilities that collectively consume over 90 percent of the Department's natural gas and 75 percent of its fuel oil were under study to establish such data as age of equipment, fuel sources, projected load growth, and local energy market. The results will be used for planning an effective fuel conservation program.

Development of plans describing the contingency actions to be taken in the event of curlailment or other unavailability of primary energy sources is another important aspect of DOE's general operations program.

DOE's energy awareness program has included dissemination of energy-related material through newsletters, posters, films, lectures, seminars, stickers, and decals. A more formal energy conservation awareness program was started in late 1978 with a survey of related activities in industry and other govern. ment agencies. The first draft of guidelines for a DOE energy conservation awareness program was published in March, 1979, and a pllot energy conservation awareness program was started at DOE's Germantown, Maryland, installation in May, 1979. Implementation of such a program throughout $D O E$ is planned to begin early in FY 1980.

DOE's in-house energy management program-an active multi-faceted one comprising a variety of energy awareness, buildings, and general operations programs-will resull in cumulative energy savings of 58.5 trillion Btu by the end of FY 1985 , or about $\$ 260$ million.

\section{UNITED STATES POSTAL SERVICE}

The U.S. Postal Service (USPS), the world's largest mail system, has as its basic function the obligation to provide postal services to bind 
the nation together through the personal, educational, literary, and business correspondence of the people. The Postal Service employs over 655,000 people, more than any non-military agency of the government, constituting nearly one percent of the national work force.

The Postal Service recognized that energy resources would be in short supply and took positive action early. They have achieved a reduction in energy consumed in buildings of approximately 17.6 percent between FY 1973 and FY 1978. In Fy 1978, overall energy used decreased by 597 billion Btu's as compared to FY 1975 despite a 14 percent increase in building inventory and a 9.9 percent increase in the vehicle fleet.

Minimum long-range goals are a 20 percent reduction in usage in existing buildings and a 20 percent reduction in gallons per postalowned vehicle by 1985. In addition, Postmaster General Bolger has established an FY 1979 ab. solute minimum goal of five percent reduction in all energy usage.

Vehicle fleet has increased 9.9 percent in FY 1978 over base year of FY 1975 making a strong energy program imperative. A program of route evaluation, driver training, mileage control, and vehicle maintenance has been developed, guidelines published, and field follow-up action implemented. Delivery of 9,000 1/4-ton vehicles with a new 4-cylinder engine should be completed in FY 1979. Purchase of an additional 750 electric vehicles to augment current fleet of 383 has been approved. These actions will sig. nificantly increase average fleet rated MPG.

Specific energy guidelines and procedures have been issued to each installation head or postmaster. Postmasters are required to report energy consumption on a regular basis. All maintenance training involves the discussion of energy and energy conservation. Energy conservation seminars hvae been held at both the Postal Management Academy in Bethesda, Maryland, and the Maintenance Technical Center in Norman, Oklahoma. Each postal regional has an energy incentive and/or award program both for the individual and buildings.

The Postal Service has an active ongoing Energy Investment Program (EIP). The program is directed at making cost effective structural, electrical and mechanical modifications to both owned and leased buildings. The plan is to apply the program in four phases starting with the largest buildings and progressing to smaller ones. Ultimately over 18,000 buildings will be affected. Total program costs are estimated to be approximately $\$ 45$ million.

Funds in the amount of $\$ 23.2$ million have already been approved by the Postal Service for Phases I and II covering the largest 360 owned or leased buildings. Energy audits have been completed for all buildings greater than 25,000 square feet. Results of these audits will be used to establish priorities for first three phases of EIP. Audits for remaining buildings will be completed in FY 1980 after planned computerized reporting system is brought on-line.

In addition to the Energy Investment Program, a Model Post Office Program was begun in May of 1979. Each of the five regions have chosen an existing office as the model for energy conservation with the objective of making them a minimum energy user.

The U.S. Postal Service is installing solar energy in various applications on a nationwide basis. The Postal Service considers solar installations to be developmental projects and the installation to be an effort to advance the state of the art both within the Postal Service and for the benefit of the nation. Limited experience reinforces the belief that further development is necessary.

The Postal Service's solar program began in 1975 and now includes seven buildings of various types and stages of development.

Three demonstration projects completed by the Postal Service have involved active solar systems, supplying both heating and cooling. These are serving post offices varying in size from 6,000 to 36,000 square feet, and are located in Ridley Park, PA; Houston, TX; and Boulder, CO. Two additional active solar projects are under construction in St. Louis, Mo. and Guayama, P.R. and are scheduled for completion in 1980. A passive solar design is being studied for the Park, CO. post office and an active solar system is planned for the Aspen, CO. post office.

During the next year, the Postal Service will initiate ten solar domestic hot water heating projects, several passive type new construction 
projects and the direct conversion of an existing absorption system to solar by installation of high temperature type collectors.

Additionally, a geothermal project, in conjunction with the City of Klamath Falls, Oregon, will be completed by 1980 .

\section{GENERAL SERVICES ADMINISTRATION}

The General Services Administration (GSA) provides a variety of products and services to other Federal agencies. The range of services provided by GSA includes, but is not limited to procurement of ADP equipment and services; civil emergency preparedness mangement to respond to national crises; processing of excess and surplus Federal real estate; procurement of general supplies and cars and trucks; collecting and maintaining America's heritage materials and managing records; construction and management of government-owned buildings and the leasing of privately-owned ones, operation of the Interagency Motor Pool System; and involvement in utility ratemaking for the Federal Government.

GSA has implemented a number of programs designed to save energy through waste material recycling and energy conservation and to promote the development and utilization of alternative energy sources. Several of these programs and their results are discussed below:

- Energy Intensive Products (Life Cycle Costing (LCC)) Program-Thus far, this program is a procurement effort utilizing LCC which considers purchase price and other ownership costs to arrive at the lowest total ownership cost to the government for appliances. In FY 1978, awards were made for electric and gas ranges and water heaters representing an estimated 500 billion Btu in life cycle energy savings and an estimated $\$ 475,000$ in life cycle cost avoidances. There are 96 planned contract awards in this program from FY 1979 through FY 1985. Other efforts in GSA's Federal supply service should have positive effects on water conservation, thermal insulation, and use of recovered materials.
- General Transportation Program Summary -The GSA Interagency Motor Pool System (IMPS) contains approximately 88,000 vehicles. During FY 1978, 15,294 passenger vehicles were acquired for Federal fleets at a fleet average fuel economy of 21,0 mpg against a required acquisition fuel economy target of $20.0 \mathrm{mpg}$. The FY 1978 acquisition is expected to have a cost avoidance of $\$ 11,200,000$ over the projected 60,000 mile vehicle life. Beginning with FY 1979, the Federal acquisition program extends to light trucks up to 6,000 gross vehicle weight rating (GVWR).

In terms of actual gasoline used for GSA operated motor vehicles, GSA has reduced its gasoline from $1,426,817$ gallons in $F Y$ 1975 , to $1,358,538$ gallons in FY 1978 . This represents an energy level savings of 8.4 billion Btus in FY 1978 comparcd to FY 1975.

- Tire Retreading Program-Cumulatively, from FY 1975 through the first half of FY 1979 , program costs of $\$ 24.5$ million were incurred with a cost avoidance of $\$ 42.0$ million. In the first two quarters of FY 1979 , $1,083,000$ tires were retreaded in four and a half years with a total energy savings of 18.4 million gallons of petroleum products to the nation. Each truck tire retreaded represents a petroleum savings of approximately 20 gallons. Each passenger tire retreaded represents a petroleum savings of approximately five gallons.

- Wastepaper Recycling Program-This program makes a pusitive energy savings cuntribution to the manufacturing process for making new paper products. This savings occurs as a result of a lessened need for primary energy to replace used paper. Through GSA's ongoing program from FY 1975 through the first half of FY 1979, an energy savings of 1,960 billion Btus was made to the nation. Proceeds for these years were $\$ 4,289,000$ with cost avoidance of approximately $\$ 2,239,000$.

It is estimated that 25,000 tons of wastepaper were sold by GSA in FY 1975 (baseline year), resulting in energy savings of 4,000 billion Btus and proceeds of approx- 
imately $\$ 700,000$ with a $\$ 300,000$ cost avoidance. In FY 1978, there were $\$ 1,075,000$ of proceeds with a $\$ 575,000$ cost avoidance for 31,500 tons of paper.

GSA is in the process of implementing the Environmental Protection Agency, Source Separation for Material Recovery Guidelines, which are mandatory for Federal agencies. Deck top source separation programs are being initiated nationwide and should greatly increase the amount and quality of wastepaper sold and recycled.

- Existing Buildings Summary-In existing buildings, the overall absolute energy use was 44.8 trillion Btu in 1975 (adjusted base year) and 44.6 trillion Btu in 1978, including projections. Considering a constant square feet workload since 1975, GSA consumption in 1975 was 42.9 trillion Btu and in 1978 was 41.7 trillion Btu. Existing buildings absolute consumption for first through second quarter 1979 is 24.2 trillion Btu. As the direct cost of utilities/fuels has grown from $\$ 72.2$ million in 1973 to $\$ 132.2$ million in 1978, the direct utilities/fuels cost avoidance has increased from $\$ 21.9$ million in 1974 (firet full year benefit) to $\$ 46.7$ million in 1978. Thus far, GSA has surveyed or has ongoing 32.3 percent, or 51.6 million square feet, or occupiable square footage. Seven percent, or 12.8 million square feet, of occupiable square footage is in retrofit design or construction work.

- New Buildings Summary-PBS has developed a New Buildings Construction Program using the concept of energy performance criteria in the design of new construction. This approach allows maximum flexibility and latitude in the buildings' overall development while insuring desired operating characteristics.

PBS initially developed a fixed annual consumption goal of $55,000 \mathrm{Btu} / \mathrm{gsf}$ for the building boundary and 100,000 Btu/gsf for raw source usage. This criteria will meet all mandated goals. With improvements in the state-of-the-art design, however, PBS is now considering the use of individual building goals to optimize building performance through even more challenging energy criteria. Several new construction efforts are being evaluated for the new performance goals.

The new building baseline has been modified this reporting year. This results from added buildings in the data base from the 1975 transition quarter.

- Leased Building Summary-To achieve energy conservation in leased buildings, GSA is specifying energy saving levels of heating, cooling, and lighting. Buildings constructed for Federal lease are required, by design, to meet the same energy performance goal of new federally owned buildings. Offerings of space over 30,000 square feet to the government for lease is required to contain data on energy use, and energy use becomes an award factor. GSA is planning to study recent buildings constructed for Federal lease and designed for energy efficiency, and plans to adopt life cycle costing to leasing.

- Solar Energy in Buildings Summary-Thus far, GSA has completed six solar energy systems, with another ten under construction or design, and nine more planned. 19,600 equare feet of collestor is represented by the completed projects. One hundred sixty-five solar energy system feasibility studies have been completed, are ongoing, or are planned. Of these 21 are complete and 106 are ongoing. GSA solar energy systems installed, under design, or construction represent a wide spectrum of the country and in varying degrees involved space heating, space cooling, and hot water requirements.

\section{VETERANS ADMINISTRATION}

A thorough system of benefits for veterans and dependents is administered by the Veterans Administration (VA). These benefits include compensation payments for disabilities or death related to military service, pensions, education and rehabilitation, home loan guaranty, burial, and a comprehensive medical program involving a widespread system of nursing homes, clinics, and more than 170 hospitals. 
The Veterans Administration, during the past year, has simultaneously (1) continued to provide high quality care and services for the American Veteran and his dependent; (2) continued to reduce significantly the energy required to operate medical-care centers efficiently, and (3) continued to expand and improve eight basic functions of its overall program designed to exceed the requirements of Executive Order 12003.

By the end of FY 1977, their energy consumption in Btu per square foot had been reduced 11.92 percent from the 1975 level of 367,966 to 324,120 . As of March 31, 1979, this figure has been further reduced to 303,030 for a total reduction of 17.65 percent from a comparable FY 1975 base.

Since FY 1975 , the VA has competed retrofit projects costing $\$ 23$ million. These conservation projects have resulted in a reduction in annual energy usage of 7,286 billion Btu per year compared to $F Y 1975$ usage. This reduction equates to $\$ 19,672,000$ a year in cost avoidance.

The VA's energy conservation program has eight basic functions: (1) research and development, (2) a historical energy data bank, (3) training, (4) buildings surveys by energy conservation specialists, (5) management by objectives planning applied to energy conservation, (6) cost effective funding, (7) accomplishment and follow-through, and (8) analysis of results. Examples of the program's accomplishments during the past year include publishing new heating, ventilating, and air conditioning standards for VA hospitals, publishing information on 22 common energy conservation opportunities, establishing FY 1980 conservation goals, developing a computer program for determining the theoretical minimum energy consumption for facilities, and completing 95 percent of a 10-year plan covering the eight functions listed above. In addition, studies are being completed for two cogeneration installations and for two conversions to geothermal energy.

\section{DEPARTMENT OF TRANSPORTATION}

The U.S. Department of Transportation (DOT) established the nation's overall transportation policy. Under its umbrella there are seven ad- ministrators and the Materials Transportation Bureau whose jurisdiction include: highway planning, development, and construction; urban mass transit, railroads; aviation; and the safety of waterways, ports, highways, and oil and gas pipelines. Decisions made by DOT in conjuction with the appropriate state and local officials strongly affect other programs such as land planning, energy conservation, scarce resource utilization, and technological change.

For FY 1978, the Department of Transportation has recorded an overall increase in energy use of about six percent over the FY 1975 base level. In the area of building operations, the Department's building square footage has increased from $31,837,000$ to $37,822,000$ gross square feet, or about a 20 percent increase. It should be noted that energy use for buildings has remained about ronnstant. In terms of Btul GSF of building space, energy consumption has decreased, evidenced by the fact that it has dropped from $15,789 \times 10^{9} / 31.8 \times 10^{6}=497 \mathrm{~K}$ Btu/GSF in FY 1975 to $15,866 \times 10^{9} / 37.8 \times 10^{6}=$ 419K Btu/GSF in FY 1978 , or about 16 percent decrease in energy consumption. From the above, it is clear that although the Department does not show a net savings in current energy use over the FY 1975 base year due to increase in floor area, the Department does show that our operations are much more efficient due to concerted efforts to conserve energy. For vehicle and equipment operations, energy use increased 1.4 trillion over the FY 1975 baseline level. Expanded mission responsibilities are the primary reasons for these increases.

Of the total energy use reported by DOT, the United States Coast Guard (USCG) accounts for 51 percent, the Federal Aviation Administration accounts for another 46 percent, and other operating elements total three percent. DOT has 110,500 employees, of which 36,807 are USCG personnel.

The increased mission responsibilities of the USCG include monitoring the 200 mile Fisheries Management Zone, expanding drug interdiction efforts, ice-breaking, pollution cleanup and prevention operations, and installing, monitoring, and maintaining a larger number of marine navigation aids.

The Coast Guard has effected savings through the following guidelines: 
- The number of ships, aircraft and boats in patrols or exercises will be limited to the minimum essential to accomplish the objective

- Except for emergencies, sorties have been combined to minimize multi-mission use of resources. Unless significant benefits will accrue, public relations requests for U.S. Coast Guard services are denied

- Cutters and boats will operate at the most economical speed consistent with mission requirements

- Simulators will be used to the maximum extent possible.

The mission of the FAA now requires a larger number of facilities and installations to be checked, maintained and monitored compared to FY 1975. Also, the replacement of piston engined aircraft with turboprops and turbojet engines has resulted in an increase in the use of jet fuel. Even with increased mission responsibilities, a 144 billion Btu reduction in energy use (compared to FY 1975) has been achieved.

The FAA's aviation industry conservation program has improved U.S. air carriers' revenuc-ton miles per gallon by 23.1 percent since FY 1975. Other programs include energy efficient approach lighting systems studies, pilot fuel consumption training, and fuel burn calculations for specific airplanes and routes.

In FAA buildings, various mechanical and electrical improvements have been planned or installed to improve overall efficiency. Photovoltaic retrofit installations are being designed to supplement power in selected buildings and navigation aids.

The Federal Highway Administration (FHWA) has reduced its automotive fuel consumption by 32 percent since FY 1975, while building energy use increased by 25.5 percent over the same period. Expanded office and research space has contributed to the increased build. ing energy use. Technical assistance energy conservation surveys are in process or planned to help reduce energy usage.

The Transportation Test Center (TTC) provides a center for $R \& D$ related to railroad and urban mass transit. The center décreased its overall energy consumption by 4.7 percent compared to an FY 1975 baseline, adjusted for expanded mission responsibilities. Gas rationing, decreasing the size of the motor pool, and the increasing use of fuel efficient vehicles have reduced adjusted fuel consumption by 6.2 percent in FY 1978 and over eight percent for the first two quarters of FY 1979. Energy conservation is considered in all procurement, with life cycle costing being a major factor in any purchase. Metering has been installed at several locations and other applications have been planned.

The TTC has also installed two solar heating and hot water systems and is designing a photovoltaic system to operate a pump in a remote area.

\section{NATIONAL AERONAUTICS AND SPACE ADMINISTRATION}

The National Aeronautics and Space Administration (NASA) conducts space and aeronautical activities for peaceful purposes for the benefit of all mankind. In maintaining United States leadership in research, technology, and utilization in these fields, NASA's programs:

- Extend man's knowledge of Earth, its environment, the solar system, and the universe

- Expand practical applications of space technology

- Develop, operate, and improve manned and unmanned space vehicles

- Improve the civil and military usefulness of aeronautical vehicles while minimizing their environmental effects

- Disseminate pertinent findings to potential users

- Promote international cooperation in peaceful activities in space.

In 1970, the National Aeronautics and Space Administration initiated a "low key" energy reduction program to reduce utility costs. During FY 1975, a goal of reducing utility energy consumption 50 percent by FY 1985 was established using FY 1973 as a base year. At the end of FY 1978, NASA field installations achieved a collective reduction of 37 percent versus the $F Y$ 1973 baseline. The cumulative reduction 
equates to over 7.6 million barrels of oil that has been saved to date. In addition, since FY 1975 (adjusted base year to relate to more recent Federal guidance), energy consumption in NASA has been reduced by 18 percent in three years, just two percentage points below the President's goal.

Early conservation efforts consisted of many small low cost initiatives. Through FY 1975, work progressed on formalizing the NASA Energy Management Multiyear Action Plan. The Plan was initially approved in January, 1976, by the Deputy Administrator of NASA, and timely updates have been issued. An integral part of the program is the forecasting of energy consumption levels for each fiscal year and the identification of conservation initiatives and their corresponding facility project investments. The planning and forecasting is developed for each field installation.

The overall program goal of 50 percent reduction compared to FY 1973 is achievable and accommodates within itself all published national and Federal Government energy reduction goals. This represents a 35 percent reduction from the FY 1975 "adjusted base" but it is NASA's intent to continue to "track" performance using both baselines. The ultimate achievement of the 50 percent goal requires continued investment of resources and management support at all levels.

Energy mangement, with associated energy reductions, has not compromised NASA's mission to date. On the contrary, conservation goals have increased the quality of research, enhanced productivity, and reduced overall costs. Energy conservation at NASA is proving to be just "good business," and must be further pursued.

An agressive energy management program continues to be implemented. Incorporated within the program are the establishments of an Energy Management Data Base and budgetary priorities for energy management and facility project investment. Awareness and concern for efficient energy utilization at the agency continues to increase.

A systems approach to energy conservation has been developed by NASA to determine the best combination of initiatives for the most effective expenditure of funds.
Projects submitted by the field installations are reviewed by the Facilities Division for assignment to a given fiscal year Construction of Facilities program.

The general criteria for project consideration is "simple amortization" and the relationship between the energy saved and the dollar investment. Simple amortization periods of five years or less are still preferred. For FY 1980 and prior year programs, a "payback" of less than five years was achieved. The Energy Effectiveness Index, which is the ratio of millions of Btu's saved per $\$ 1,000$ of investment, is also applied. Other criteria includes considerations euch ao improvements in work efficiency, associated benefits of facility modernization, and the importance of the facility to NASA's mission.

\section{DEPARTMENT OF INTERIOR}

The Department of the Interior (DOI) has responsibility for most of our nationally owned public lands and natural resources. This includes fostering the wisest use of our land and water resources, protecting our fish and wildlife, preserving the environmental and cultural values of our national parks and historical places, and providing for the enjoyment of life through outdoor recreation. The Department assesses our energy and mineral resources and works to assure that their development is in the best interests of all our people. The Interior Department also has a major responsibility for American Indian reservation communities and for people who live in Island Territories under United States administration. The jurisdiction of the Department of the Interior includes the administration of over 500 million aeres of Federal land, and trust responsibilities for approximately 50 million acres of land, mostly Indian reservations.

For the past two years the Department of the Interior has been developing and incrementally implementing a comprehensive energy conser. vation/management plan to respond to Executive Order 12003 and Public Law 95-619. During FY 1978 Interior established an overall energy consumption goal in Btu that would limit the energy consumption to a value that would not exceed the reported level for the FY 1975 base year. The goal was exceeded by 3.3 
percent. However, energy costs increased by 24.7 percent from FY 1975 levels.

The total inventory of Interior owned and GSA leased vehicles was reduced by 8.7 percent or 2,415 vehicles in FY 1978 compared with FY 1977. In addition to the reductions in the number of vehicles, the Department experienced a trend toward more compact vehicles. One major action which contributed to this change was that an annual forecast of motor vehicle acquisitions was developed, and all motor vehicle acquisitions were authorized according to that forecast by a single official in Interior.

During FY 1978 energy consumption in buildings was reduced by 2.3 percent in Btu and 11.9 percent in Btu/gsf compared with the Fy 1975 baseline. However, energy costs increased by 31.6 percent during this period.

Preliminary energy audits were conducted on all Interior owned and operated buildings over 30,000 gross square feet. A significant number of audits were also conducted on buildings 1 to 30,000 gross square feet. Several energy surveys were conducted on buildings whose preliminary energy audits had been completed. Retrofit projects were identified to improve the efficiency of the buildings.

Energy data was revised to account for the functions and buildings transferred to other agencies. A more accurate Fy 1975 reporting baseline was submitted to DOE. Data refinement for all years from 1975 to the present is still underway, to ensure that all data, both past and future are accurate and consistent.

In FY 1978 Interior participated in various demonstration projects. Some projects which are noteworthy of mentioning are: (1) a 100 kilowatt peak solar photovoltaic system at the Natural Bridges National Monument in Utah; (1) tracking concentrating solar collectors at the National Fisheries Center in Leetown, West Virginia and (3) completion of plans and dedication of funding in selected applications to examine the potential to future use of these vehicles across the Department.

\section{DEPARTMENT OF AGRICULTURE}

The Department of Agriculture (USDA) works to improve and maintain farm income, and to develop and expand markets abroad for agri- cultural products. The Department helps to curb and to cure poverty, hunger, and malnutrition. It works to enhance the environment and to maintain our production capacity by helping landowners protect the soil, water, forests, and other natural resources. Rural development, credit, and conservation programs are key resources for carrying out national growth poli. cies. USDA research findings directly or indirectly benefit every American. The Department, through inspection and grading services, safeguards and assures standards of quality in the daily food supply. To carry on its work, the Department employs approximately 85,000 fulltime personnel and conducts activities at over 10,000 locations worldwide.

An overall energy use reduction of nearly 700 billion Btu was recorded in FY 1978, compared to FY 1975 energy levels.

Energy use in general operations increased by 184 billion Btu, compared to FY 1975 levels. Vehicle transportation energy consumption amounted to 57 percent of all Department energy use in FY 1978. The increase in general operations is accounted for by increased gasoline consumption. Programs have been implemented to purchase fuel efficient light trucks. In FY 1979 , the goal is the achieve a fleet average fuel economy of $19.2 \mathrm{mpg}$, two mpg above the mandated $17.2 \mathrm{mpg}$, and the program will continue through FY 1985. The Department is contem. plating purchasing or leasing up to $15,000 \mathrm{com}$ pact sedans for use in place of privately owned vehicles, which now account for 35 percent of mileage driven.

Departmental buildings and facilities encompass more than 20 million gross square feet of floor area. The USDA has completed preliminary energy audits on buildings over 30,000 gross square feet and anticipates completing them on buildings over 1,000 square feet by July, 1980. The cost of this program is estimated to be $\$ 800,000$. Prior to the renewal of leased space, an energy audit is performed to determine the energy efficiency and retrofit potential of that space. If the lease is to be renewed, the Agency will incorporate the implementation of those identified energy conserving actions in the contract.

The department participates in the photovoltaic demonstration program. A total of 112 projects have been funded for demonstration in 
FY 1979 including remote sensing, power for lookout towers, communications, and electrified livestock fencing. Photovoltaic powered installations are also used to measure the snow. pack in remote mountain areas.

An extensive program of employee awareness training is provided with USDA and includes publications and posters, awards programs,car pool matching programs, van pools and com. plete mass transportation schedule information.

\section{DEPARTMENT OF HEALTH, EDUCATION, AND WELFARE}

The Department of Health, Education, and Welfare (HEW) is the Cabinet-level department of the Federal Executive branch most concerned with people and most involved with the nation's human concerns. In one way or another, whether it is mailing our social security checks, or improving the quality of American education, or making health services more widely available, HEW touches the lives of more Americans than any other Federal agency.

The Department of Health, Education, and Welfare consumed a total of $8,655 \times 10^{9}$ Btus of energy in FY 1978. HEW used this energy in the 20.2 million square feet of owned real property which the Department reports in the Federal Energy Management Program. These data do not include the 160 school facilities owned by HEW but operated by either the Department of Defense or local school districts. Nor do they include the space purchased by the SSA Trust Fund, but operated by the General Services Administration.

This past year has been a successful period in HEW's efforts towards achieving the President's goal of a 20 percent reduction in building energy consumption by 1985 . The department achieved a five percent reduction in consumption after two years of slight increases and despite several fiscal constraints which limited capital investments in energy conservation projects.

HEW will continue its efforts to improve its building energy conservation. However, HEW often encounters the difficulty of implementing stringent energy conservation policies and practices in facilities supporting health care and health research activities. In these ac. tivities, one must closely control environmental conditions and cannot subject the activities to wide-ranging temperatures, humidities, or air qualities. These concerns may warrant the rejection of otherwise technically sound energy conservation measures.

HEW energy savings in "general operations" fall into two categories:

(1) Utilities savings

(2) Transportation savings.

HEW cannot directly measure energy savings in its utilities operations because we do not meter utility consumption separate from the energy used to run entire facilities. Therafore, we inror. porated our utility energy savings into the energy use data in the Building Program section.

In conducting its FY 1978 transportation activities, HEW saved 649,000 gallons of gasoline over the amount used in FY 1975 (an 11 percent reduction)-a cost savings of about $\$ 520,000$ (at $\$ .80$ per gallon).

\section{DEPARTMENT OF JUSTICE}

As the largest law firm in the nation, the Department of Justice (DOJ) serves as counsel for its citizens. It represents the public interest through the enforcement of the law. Through its thousands of lawyers, investigators, and agents, the Department plays a key role in protection against criminal and subversive acts, ensuring healthy competition of businese in our free en. terprise system, in safeguarding the consumer, an enforcing drug, immigration, and naturalization laws. DOJ employs a total of $53,854 \mathrm{em}$ ployees in its headquarters and field offices.

During Fiscal Year 1978, the Department of Justice's (DOJ) total energy consumption in Buildings and Facilities Operations increased by 7.7 percent and Vehicles and Equipment Operations increased by 5.6 percent. The notable increases were the result of the opening of four new institutions by the Bureau of Prisons (BOP). These actions also increased BOP's vehicle fleet by 13 percent and the total facilities square footage by seven percent.

On May 11, 1979, a departmental plan was submitted to the Secretary of Energy for achiev. ing an overall five percent reduction in energy consumption in buildings and a 10 percent reduction in fuels used in administrative vehi- 
cles. The heads of all DOJ organizations were provided copies of the plan and requested to ensure that immediate steps were taken by all employees to implement the planned actions cited therein.

Additionally, the Assistant Attorney General for Administration requested administrative personnel in each DOJ organization in headquarters and field locations to survey all assigned space for excessive use of electrical items such as coffeemakers, hot plates, portable electrical heaters, radios, and electric fans, and take corrective action to minimize the consumption of electricity.

DOJ employees are encouraged to use mass transit and join or form car pools through the departmental parking office. Currently DOJ has approximately 1,106 car pools in the Metropolitan Washington area. Each car pool is com. posed of an average of five members. In some cases, employees have been permitted to work flexible hours in order to join car pools.

BOP has begun installing load-demand controllers in several of its new and existing facili. tles. These controllers are used to balance the demand for power through the control of various electrical power loads as well as monitorIng the quarilities of power used. The advantage of the controllers is that they reduce the range of demand between low and peak quantities, thus reducing overall utility costs and energy use.

After the 1980 Winter Olympic Games in Lake Placid, New York, the Olympic Village will be converted to a minimum security institution operated by BOP. An energy research study will focus on five identical, newly constructed buildings to house Olympic contenders during the Olympics and Federal offenders beginning in August, 1980. Each of the dormitory-type structures will be equipped with a different energy storage system for comparative space heating tests under closely similar conditions. What the researchers seek are heat storage methods and devices which can be compatible with and reduce costs of future electric power generation and distribution requirements.

On the renewable energy side, a solar system is scheduled to go into operation at the Federal Correctional Institution at Bastrop, Texas, in August, 1979. The system is designed to provide 96.6 percent of the hot water, 45.5 percent of the heating and 8.6 percent of the cooling energy for the entire project.

Federal Prison Industries is now producing Solar Collectors for sale to other government agencies. Both liquid flat-plate collectors and hot air flat-plate collectors are being produced.

The Immigration and Naturalization Service is investigating electronic and powergeneration systems that could be used to decrease commercial power consumption, reduce maintenance and downtime, and reduce vehicle and manpower demands, while improving response time and effectiveness. Solar and/or wind-powered base stations for intrusion detection systems and automatic vehicle location and communications centers are also being investigated.

At the Federal Bureau of Investigation Training Facility, Quantico, Virginia, the lighting in the hallways, mechanical rooms, and limiteduse areas has been reduced from 20 footcandles to 5 footcandles. Chemical additives are also being introduced to the fuel oil used in the power plant boilers which increase the burn temperature, thereby decreasing the amount of fuel necessary to perform a specific function.

The size of the Drug Enforcement Administration's vehicle fleet was reduced by 10 percent of approximately 250 vehicles at the end of June, 1979. Planned actions will be effected to subsequently reduce the active fleet by an additional five percent.

\section{DEPARTMENT OF THE TREASURY}

The Department of the Treasury performs four basic functions: formulating and recommending financial, tax, and fiscal policies, serving as financial agent for the U.S. Government, law enforcement, and manufacturing coins and currency.

In FY 1978, the Treasury Department used 4.27 trillion Btu of energy, compared to 3.96 trillion in Fy 1976. Expansion of the Federal Law Enforcement Training Center (FLETC) to include over 1.3 million square feet of available floor space and the conversion of unconditioned storage areas to office space at other locations has caused the increase in total building energy consumption. 
During FY 1978,15 buildings of 30,000 square feet or more were audited, and 12 of these buildings were surveyed in detail for energy conservation options. All IRS facilities are administered by GSA and since the base year of FY 1975, GSA has reduced overall energy use by 3.5 percent in the 10 IRS Regional Data Processing Service Centers. A special survey conducted by a joint IRS/GSA National Office task force identified conservation actions at the Memphis Service Center, which will add to previous energy saving efforts to produce a 35 percent reduction. Comparable savings were identified at the Andover Service Center. The task force will survey the remaining eight IRS service centers in the near future.

Over 50 percent of Treasury's energy consumption is attributable to transportation, more specifically the use of the automobile, and another 30 percent of energy is consumed in industrial operations. A short term goal of 10 percent reduction in automotive fuels is being pursued in accordance with the President's Memorandum of April 10,1979, "Required five percent Reduction in Agency Use." In the long term a much greater reduction in motor vehicle fuel will be vigorously pursued. More fuel efficient automobiles are being introduced into the Treasury fleet, and the Department has met the mandated fleet average fuel economy goals. Although law enforcement vehicles are excluded from the Executive Order, law enforcement bureaus have continued to purchase more fuel efficient vehicles to reduce overall gasoline usage.

Energy conservation efforts in mints, assay offices, and data processing areas have been extensive. Immediately applicable, noncapital improvements have been implemented at a savings of 10.38 billion Btu. Solar energy demonstration projects have been installed at three U.S. Customs Service locations and additional systems are planned for use in the mountains of the southwest United States. At two of the sites, photovoltaic energy systems will save over $\$ 37,200$ during a five year period with a system cost of only $\$ 4,900$. Other programs instituted by the Department of the Treasury include: an active car pooling program, special IRS buses serving the Memphis Service Center to reduce private auto use, FLETC fuel conversion program to equip all central heating plants with the capability of using either natural gas or fuel oil, and reclaiming waste heat from automatic data processing equipment at the IRS facility in Martinsburg, West Virginia.

\section{DEPARTMENT OF COMMERCE}

The Department of Commerce encourages, serves, and promotes the nation's economic development and technological advancement. It offers advice and information to domestic and international business, provides social and economic statistics and analyses for business and government planners, assists in the development and maintenance of the U.S. Merchant Marine, provides research for and promotes the increased use of science and technology in the development of the economy, and provides assistance to speed the development of the economically underdeveloped areas of the nation.

The Department energy conservation program consists of two programs; The General Operations Program and the Federal Buildings Program.

In the general transportation area the Department purchased or leased the numbers and types of fuel efficient vehicles which resulted in a vehicle fleet average of $20.2 \mathrm{MPG}$ in FY 1978 and 22.08 MPG in FY 1979 which meet Presidential established goals of fuel economy. General operations energy use constitutes 35.37 percent of the total energy in 1978 as compared to 31.50 percent in 1975 , a 3.87 percent Increase. Increased travel in preparation for the 1980 census, increased jet fuel necessary to support storm watch flights and increased ship activity in the National Oceanic and Atmospheric Administration and the Maritime Administration contributed to this increase in fuel usage.

In FY 1978 the Federal Buildings Program accounted for 64.60 percent of the Department account of energy used. This is a 3.86 percent reduction when compared to the 68.46 percent used in the Fy 1975 baseline. This reduction was possible in spite of the increase of total floor space. As part of the Department's effort to conserve energy preliminary energy buildings audits have been completed in all department owned buildings and facilities containing over 30,000 gross square feet of floor space. 
Audits of buildings and facilities of over 1,000 but less than 30,000 gross square feet of floor space are continuing. The adding of insulation in attics; repair, replacement and insulation of steam lines; boiler repair and cleaning; replacement of windows with insulated windows; adding timers and control devices for heating, ventilating, and air conditioning systems to efficiently regulate building temperatures; the shut down of boiler plants and switching to natural gas fed heaters; replacement of high energy use equipment; the turning off of lights not needed; and other operation maintenance and retrofit activities identified by these energy audits contributed to this overall reduction in the use of energy.

Car and van pooling programs initiated in each operating unit have resulted in the participation of thousands of employees. It is not possible, however, to accurately measure the total fuel savings that have resulted from these programs.

\section{PANAMA CANAL COMPANYI CANAL ZONE GOVERNMENT}

The Panama Canal Company/Panama Zone Government (PCC/CZG) maintains and operates the Panama Canal and conducts business operations involving the Canal and the civil government of the Canal Zone. Operations include the waterway, harbor terminals, electric, telephone and water systems, and employee service activities.

The Panama Canal Company/Canal Zone Government achieved a total cumulative energy savings of $402.2 \times 10^{9}$ Btu between FY 1975 and the end of the second quarter of FY 1979. These savings represent a cost reduction of about $\$ 799,200$ or over 69 thousand barrels of oil equivalent. The percent total energy saved in FY 1978 compared to FY 1975 was 7.3 percent.

The above figures show that their energy management conservation program is highly successful. The Company/Government has concentrated its efforts at energy savings by reducing energy demands for lighting, air conditioning and motor pool operations, and through the conservation efforts of all personnel within the various bureaus and staff units of this agency. These savings in energy have ac- crued without loss of operational efficiency and without compromising their mission to operate and maintain the waterway.

The PCC/CZG overall energy management plans are to insure compliance with Presidential mandates and guidelines to reduce total energy consumption. At present they have developed and implemented a new energy program in order to achieve this agency's reduction in energy usage as required by President Carter's memorandum issued April 10, 1979, to all Federal agencies. The specific actions which are implemented will result in further reductions in energy and will achieve the five percent reduction goal in relation to the prior twelve month period.

A substantive reduction in the Company/ Government energy management program will result after October 1, 1979, when the new Panama Canal. Treaty becomes effective. The PCC/CZG will be replaced by a Panama Canal Commission which will have no authority to conduct most business-type activities or governmental functions that are now closely related to their mission and operations.

Their capital budget through FY 1980 shows three major projects with the primary purpose of reducing energy consumption as follows:

- To install vinyl siding on 549 employee quarters of wood construction to provide more effective insulation

- To repower the suction dredge U.S. MINDI from steam to diesel machinery, with an estimated energy saving of about 65 billion Btu per year

- To replace gasoline powered vehicles with diesel powered and more efficient compact gasoline powered vehicles to reduce fuel consumption.

The Company/Government also has two projects that use solar energy. The first is a telemetry network with 27 stations in the Canal watershed which will result in less maintenance and operational costs. The second project, which is in the experimental stage, consists of four lighted navigational buoys, each refitted with a small lead-acid battery and a solar panel to recharge it. If these prove successful in the field, an additional 175 lighted buoys may be converted to dependence on solar energy. 


\section{DEPARTMENT OF LABOR}

The purpose of the Department of Labor (DOL) is to foster, promote, and develop the welfare of the wage earners of the United States, to improve their working conditions, and to advance their opportunities for profitable employment. In carrying out this mission, the Department administers more than 130 Federal labor laws guaranteeing workers' rights to safe and healthful working conditions, a minimum hourly wage and overtime pay, freedom from employment discrimination, unemployment insurance and workers' compensation. The Department also protects workers' pension rights, sponsors job training programs, helps workers find jobs, works to strengthen free collective bargaining, and keeps track of changes in employment, prices, and other nalional economic statistlcs.

The Department of Labor's participation in the Federal Energy Management Program is chiefly one of cooperating with the policies and guidelines issued by the President, Department of Energy, and the General Services Administration.

Because of the tremendous growth in existing programs, and the addition of new programs, their energy consumption with respect to the automotive fuel category has shown a steady large increase over the base year. They have attempted to follow a common sense approach in minimizing this consumption, while still effectively pursuing their mission and functions.

Most of their activities are housed in GSA controlled facilities. The only exceptions are the Job Corps Centers, which provide residential training programs for disadvantaged youths, and are primarily oriented towards vocational training.

The Job Corps program has also been in a state of expanding transition since 1977, and it is expected that this will continue through 1980. It is anticipated that the enrollment will double in the centers over which the DOL exercises jurisdiction and control

Due to the expansion, detailed surveys of each facility are being made to update energy use data.

Stringent conservation measures have been instituted in the DOL controlled centers to minimize energy consumption, and solar heating projects are being researched for five centers.

\section{TENNESSEE VALLEY AUTHORITY}

The Tennessee Valley Authority (TVA) is a government-owned corporation that conducts a unified program of resource development for the advancement of economic growth in the Tennessee Valley region. The Authority's program of activities includes flood control, navigation development, electric power produc. tion, fertilizer development, recreation improvement, and forestry and wildlife development. While its power program is financially selfsupporting, other programs are financed primarily. by appropriations from Congress.

During FY 1978, 999.060, $158 \times 10^{6}$ Btus were used in the production of $130,398,503,951$ kilowatt hours of electricty. Building energy conservation activities, rideshare programs, commuter bus operations, and the addition of more efficient vehicles in the motor pool contributed large energy savings. A paper recycling program and research and development activities also increased the Agency's energy savings.

The development of an internal energy management plan for TVA will establish energy performance goals for all TVA operations and buildings. In FY 1978 internal energy use by buildings was 42 percent less than the energy use baseline of FY 1973.

TVA, with its varied and numerous energy conservation activities, serves as a national laboratory for the testing and development of programs that may help the Nation solve some of its energy problems. Projects include: residential, commercial, and industrial energy audit programs, large scale demonstrations of solar systems and wood burning stoves, energy education and consumer communication activities, numerous biomass and renewable energy demonstrations, load control projects, rate research; energy technology transfer activities, and community service projects.

Energy conservation received a massive boost in the TVA power service area with programs such as the Home Insulation Program, Commercial and Industrial Energy Audit Program, Memphis 1,000 Demonstration, the North Georgia Wood Stove Program, and other energy conservation programs and demonstrations for TVA's electric power consumers. Additionally, 
the fertilizer industry has the potential to gain significant energy savings through the use of the pipe-cross reactor, a TVA demonstration.

\section{THE ENVIRONMENTAL PROTECTION AGENCY}

The Environmental Protection Agency's (EPA) basic mission is to regulate, establish, and enforce environmental standards "as specified in statutes enacted by Congress." Also, EPA specifically is charged with handling the environmental problems of "air and waste pollution, solid waste management, pesticides, radiation, and noise."

This is still the EPA's mission, although laws have been passed since 1975 giving the EPA more authority to enforce the standards that are set, such as the air standards for auto and other plant industries (Clean Air Act Amendments, 1977); the new technology-based standard for conventional water pollutants (Clean Water Act, 1977); set standards concerning the handling of hazardous solid wastes, and regulate and enforce these standards (Resource Conservation and Recovery Act, 1976); EPA has authority to "regulate the production and use of all chemicals harmful to public health or to the environment" (Toxic Substances Control Act, 1976). Due to the establishment of the Toxic Substances Control Act of 1976, a new program was added which gave the Agency additional positions for fulfilling these needs. EPA has set noise standards for trucks, buses, motorcycles, and other high noise machines. EPA's Research and Development provides technical data on "possible threats to health and the environment posed by the various substances which are introduced into the biosphere." Some projects being conducted by EPA's Office of Research and Development include: the relationship between human health and exposure to pollutants; the EPA Advanced Waste Treatment Program in Cincinnati which investigates new methods of purifying waste water; the Regional Air Pollution study in St. Louis which is "attempting to develop more precise predictive models of pollutant formation and transport so that air pollutant effects can be linked with sources and thus better pol. lution controls can be devised." The Agency employs approximately 14,000 people. This includes part-time as well as full-time employees.

During FY 1978, the Environmental Protection Agency completed its energy conservation plan and is now implementing the plan's requirements. Since EPA's energy conservation program has been underway for a very short time, details on energy use and savings are not yet available. Preliminary indications are that building energy use in FY 1978 was approximately 1.2 trillion Btu compared to 1.1 trillion Btu in FY 1975. Savings of 11.5 percent have been recorded for vehicle operations in the same period.

Current efforts are directed toward completion of preliminary energy audits for all buildings, waste paper recycling programs, and establishment of the FY 1975 energy use baseline. An energy awareness program is being promoted through newsletters, posters, and films.

\section{DEPARTMENT OF HOUSING AND URBAN DEVELOPMENT}

The Department of Housing and Urban Development (HUD) is the principal Federal agency responsible for programs concerned with housing needs and improving and developing the nation's communities.

To carry out its overall purpose of assisting the sound development of our communities, HUD administers mortgage insurance programs that help families to become home owners, a rental subsidy program for lower income families who otherwise could not afford decent housing, and programs that aid neighborhood rehabilitation and the preservation of our urban centers from blight and decay. HUD also protects the home buyer in the marketplace and fosters programs that stimulate and guide the housing industry to provide not only housing, but a suitable living environment. HUD employs 15,600 people in these activites.

The Department of Housing and Urban Development (HUD) ranks 18th in total energy used among the 20 Federal agencies reported in the Fiscal Year 1977 "Annual Energy Management Report." While the Department is viewed as a "moderate user" of energy, it is one of the smallest consumers and has shown a continuous reduction in petroleum and electrical use 
since the inception of the energy conservation program. This is due to management concern with conservation efforts.

- Management Actions: The Secretary has issued instruction to Headquarters' Principal Staff and Regional Administrators, and to the General Services Administration, to take appropriate measures to reduce the Department's energy consumption as directed by Presidential and Federal directives. Those include:

- Setting thermostats in HUD occupied space at 65 degrees during the day and 55 degrees during nonworking hours in the winter season. During the summer months, the thermostats will be set at ap. proximately 80 degrees.

- Issuance of new motor vehicle mileage objectives for the Regions and reducing motor vehicle travel on official business by eliminating, combining, or consolidating automotive trips, both for passengers and materials, to the greatest extent practical.

-Employee Activities: Various educational and promotional activities have been initiated, with additional materials under development, to obtain continuing particlpation by all employees. Current materials which are being readied for distribution to HUD ofices and employees are as follows:

- Energy conservation bulletin

- Posters for lobby of office display

- Leaflets covering fuel conservation practices

- "How to Save Gasoline and Money" and "Tips for Energy Savings" 


\section{SMALL ENERGY USING AGENCIES}

\section{ACTION}

All building occupied by ACTION in the United States are leased from and controlled by GSA. The agency leases 323 subcompacts, compacts, and station wagons from GSA. ACTION has a continuing program of energy awareness education for its employees which is directed at savings energy in buildings and vehicle operations. The requirements for saving energy also - apply to the Peace Corps and VISTA volunteers.

The Peace Corps operated 383 vehicles in FY 1978 and used 63.8 billion Btu in gasoline. Compared with FY 1975, this represents a 25 percent decrease in the number of agency owned vehicles and a 27 percent decrease in gasoline consumed. VISTA volunteers have reduced the fuel consumed in their privately owned vehicles by 5.7 percent below FY 1975.

\section{ADMINISTRATIVE CONFERENCE OF THE UNITED STATES}

The conference occupies space leased from and operated by GSA and does not operate any vehicles. On the rare occasions when a vehicle is leased, it is of the smallest type available. An active energy conservation program exists in the Conference directed at developing an en. ergy awareness attitude in its 20 employees.

\section{AGENCY FOR INTERNATIONAL DEVELOPMENT}

The 2,586 full and part-time employees of the AID are housed in buildings leased from and controlled by GSA. Thermostats are set at levels directed by the President, and the use of personal electric heaters is prohibited. A reduction in the number and wattage of light bulbs is encouraged, as is shutting off equipment when not in use.

The number of vehicles used by AID has been reduced since December, 1978, from ten to seven vehicles: three vans and four compact cars. Five of these vehicles are leased from the GSA and two from a commercial source. Essen- tial area trips are combined and unnecessary ones curtailed, with the most economical vehicles used in each case. The agency encourages the use of public transportation by its employees overseas. Large passenger vehicles at these overseas posts have been replaced by economy vehicles over the last few years.

\section{THE AMERICAN BATTLE MONUMENTS COMMISSION}

The ABMC employs eleven people in its Washington office. They operate no government vehicles and depend on GSA for their office space and the energy conservation guidelines that they follow.

\section{APPALACHIAN REGIONAL COMMISSION}

The Appalachian Regional Commission has a legislative mandate to coordinate Federal, state, and local efforts toward anticipating the effects of alternative energy policies and implementing programs to meet the special problems generated in the Appalachian Region. In carrying out this mandate, the Commission has 12 Federal and 115 Commission employees. The Commission occupies leased space and has no automobiles.

Some of the programs in which the Commission is involved include a pyrolysis-gas-from. wood-residue project, a coal-gasification project, a solid-waste-to-energy-conversion incinerator process producing fuel gas, and a wood for energy study.

\section{BOARD FOR INTERNATIONAL BROADCASTING}

The Board for International Broadcasting leases commercial office space for its employ. ees and has no vehicle operations. The Board's energy conservation program includes exercis- 
ing care that the use of electrical and office equipment and appliances is kept within normal limits during working hours. One of the Board's two parking spaces is reserved for car pools.

\section{CENTRAL INTELLIGENCE AGENCY}

The energy conservation goals of the CIA are to achieve compliance with executive directives and guidelines to the maximum extent possible without jeopardizing its vital intelligence mission.

Energy use in Agency buildings is the responsibility of the General Services Administration (GSA). The Agency cooperates fully with GSA in this program. Recent projects aimed at energy conservation include the design for the installation of small boilers for part-load operation when the capacity of existing, large boilers is not required. Additionally, GSA has contracted for work to improve the energy efficiency of outside air dampers and associated controls at the agency.

A substantial employee awareness campaign is being conducted urging employees to conserve energy, buth on and off the job. A variety of pamphlets stressing energy conservation, available in their credit union, were well received and additional materials have been requested from the Department of Energy.

The main area of energy use over which the Agency has significant control is transportation. Over 190,000 gallons of fuel costing the agency $\$ 118,000$ were used in administrative vehicles in FY 1978. This 16 percent increase above the 1975 base period is due primarily to expanding mission support requirements. Gasoline and diesel fuel usage for the first half of FY 1979 appears to be continuing at the Fy 1978 rate. The suburban location of the main CIA building and the locations of other CIA facilities severly limit alternatives to using official or privately owned vehicles for transportation. However, car pools are being stressed, and consideration is being given to support van pools. The Agency states that it is becoming increasingly difficult to achieve conservation measures, particularly in the areas of vehicle fuel usage, without adversely affecting the Agency's mission.

\section{CIVIL AERONAUTICS BOARD}

The CAB has a total of 800 employees. Its buildings are leased from and energy bills are paid by GSA. The agency operates five automobiles of which four are leased from GSA and one from a private source.

Since 1975, the implementation of strict travel guidelines for Board employees has reduced administrative vehicle mileage by 65.8 percent. For FY 1979, the CAB has established a goal to reduce vehicle operations an additional five percent.

The Board plans to experiment with flextime with the objective of reducing energy consump. tion and promoting greater use of mass transit. Managers may also experiment with a compressed work week. Over 70 percent of available parking spaces are reserved for car pools. An aggressive and continuing program to promote energy awareness among employees has included programs on transportation energy, lighting levels, building temperature setbacks, use of bicycles, and distribution of the Department of Energy pamphlet, "Tips for Energy Savers."

\section{THE COMMISSION OF FINE ARTS}

The Commission of Fine Arts occupies GSA space and no vehicles. In its role as an architectural review agency, the Commission is involved in the evaluation of window coatings and films to reduce solar loads and improve interior comfort. The Commission also provided advice on the installation of the solar hot water system on the Cabinet Room of the White House.

\section{COMMODITY FUTURES TRADING COMMISSION}

The 450 employees of the Commission are housed in leased space in five locations in the United States. The Commission leases two automobiles from private sources. Gasoline consumption has decreased by at least a 21 percent rate during the first half of FY 1979 when compared with FY 1978. Energy conservation activities include elimination of waste in procurement and supply delivery, the establish. 
ment of lighting, heating, and cooling policies and procedures, and the encouragement of employee car pooling programs.

\section{COMMUNITY SERVICES ADMINISTRATION}

The Community Services Administration has 1,041 employees and includes twenty-two individual facilities leased through GSA. The agency energy policy in buildings relies heavily on GSA for direction and implementation. In ad. dition, the agency has emphasized the use of car pooling, public transportation, and the utilization of federally-owned buildings for most of its office sites.

Considerable progress has been made in conserving energy in agency utilized vehicles. The fleet mix has been improved so that of the 19 GSA and commercially leased vehicles in use by the agency, all but three are either subcompacts or compacts. The agency's overall engine fuel efficiency figure has improved by two miles per gallon during the last fiscal year.

\section{DEPARTMENT OF STATE}

The Department of State's energy conservation program has been one of support and compliance with the regulations set forth by GSA. All buildings used by the Department, save one, are owned and operated by GSA. Energy conservation goals are supported, and include adherence to energy conservation standards for buildings overseas and cooperation with other nations' energy conservation measures.

\section{EQUAL EMPLOYMENT OPPORTUNITY COMMISSION}

EEOC's mission is to enforce Title VII of the Civil Rights Act of 1964, as amended, in response to charges of discrimination in employment. EEOC currently employs 2,500 persons and is expanding to 4,000 persons to staff new functions. All buildings occupied by EEOC are leased through GSA. Eight vehicles are assigned to EEOC through the GSA motor pool, including seven compact cars.

\section{EXPORT-IMPORT BANK OF THE UNITED STATES}

The 430 employees of the Export-Import Bank are housed in a single building in Washington, D.C., which is leased from and operated by GSA. The Bank leases two vehicles, one from GSA and the other from a private source. In FY 1978 , total gasoline consumption was reduced 1.3 percent below FY 1975. Further efforts by Bank employees have reduced the FY 1979 consumption rate at least an additional 12 percent.

Energy use in the office environment has been reduced through relamping with more efficient lighting systems and by curtailing overtime and weekend working. A new computer system is currently on order which will reduce computer energy use by 50 percent.

The Bank has continued to encourage car pooling, mass transit, and bicycles through participation in Washington area car pooling programs and the distribution of memorandums and internal newsletters.

\section{FARM CREDIT ADMINISTRATION}

The Farm Credit Administration is an independent agency with 230 employees engaged in the supervision and examination of the institu. tions of the Farm Credit System. The Agency leases its office space and has one sedan for administrative purposes. Employee travel is planned and scheduled in advance to consolidate trips, and the agency operates a successful car pooling program.

\section{FEDERAL COMMUNICATIONS COMMISSION}

The Federal Communications Commission (FCC) has implemented an energy conservation program for its vehicle fleet and existing build. ings. Although energy use for both vehicles and buildings has increased since FY 1975, the FCC's mission has also increased substantially. Adjusted for mission increases, the FCC realized an overall five percent reduction in gasoline and a 13 percent reduction in building energy use for FY 1978 compared to the adjusted FY 1975 baseline. 
Electricity and automotive gasoline comprise 90 percent of FCC energy consumption, and major conservation efforts have been directed towards these energy categories. The FCC's fleet comprises 171 vehicles, of which 17 are commercially leased, 94 are GSA pool vehicles, and 60 are FCC owned. For FY 1979, the primary goal for the vehicle fleet is to reduce gasoline consumption by 10 percent. To attain this goal the following actions have been initiated:

- The use of public transportation in lieu of government or private vehicle usage is required when practical.

- The major emphasis in vehicle replace. ment is fuel economy.

- The distribution of fuel saving driving habit bulletins, enforcement of the 55 mile per hour speed limit, and improved vehicle maintenance.

The FCC has implemented a building energy management program, with goals of reducing energy use in its 12 existing buildings by 10 percent from FY 75 levels by 1979 and increase overall energy awareness of the occupants of these buildings. All FCC buildings are under 30,000 square feet in area; the average size of a radio-monitoring station is 3,000 square feet. Due to the nature of the FCC's mission, the buildings have high process loads for radio equipment. The FCC has switched to more energy efficlent radio transmilters which consume 50 percent less energy than that used by conventional transmitters. Solar heating has been included in the design of three proposed facilities, and a major renovation of another facility.

\section{FEDERAL DEPOSIT INSURANCE CORPORATION}

The FDIC has approximately 800 employees and owns three sedans and three vans. The agency owns its headquarters building in Washington, D.C., and contracts for building energy services from GSA.

\section{FEDERAL ELECTION COMMISSION}

The Federal Election Commission (FEC) is an agency of approximately 250 people occupying commercial office space under a long term GSA lease. The Commission also leases two administrative sedans from GSA. The FEC complies with GSA's energy conservation programs for government leased buildings.

\section{FEDERAL HOME LOAN BANK BOARD}

The FHLBB owns its headquarters building and leases space through GSA for 41 field offices throughout the country. There are approximately 1,250 employees.

In the area of general transportation, the FHLBB's goal is to reduce energy consumption by 10 percent as compared to the previous 12 month period. By reducing the number of vehicles in the fleet to four and leasing more fuel efficient models, gasoline consumption figures for the first two quarters of FY 1979 indicate that the 10 percent goal will be met.

Because the headquarters building was not occupied by FY 1978, no data is available to evaluate attainment of energy use goals. The single 500,000 square foot building used electricity, steam, and a small quantity of emergency generator diesel oil. Energy use in this building, which was designed to be energy efficient, was 208,000 Btu/square foot in FY 1978. The Bank Board's current energy conservation goal is a five percent reduction in building energy use.

The Board actively participates in the D.C. Council of Governments' Commuter Car Pool Program and gives car pools first preference in the allocation of available parking. The Paper Recycling Program has put twenty-two tons of paper back to use since May 1977. Booklets promoting energy awareness among its employees both on the job and at home have been distributed. 


\section{FEDERAL MARITIME COMMISSION}

Charged with regulating the shipping industry, the Federal Maritime Commission employs about 350 personnel. All office space is in buildings owned or leased from GSA, and the Commission leases one vehicle. This vehicle was originally a compact, but has recently been replaced by a diesel engined model with a mileage rating exceeding current Federal requirements. Ninety percent of the Commission's parking spaces are reserved for car pools. The Commission has pursued a wastepaper recycling program for several years, returning the proceeds to the U.S. Treasury.

\section{FEDERAL MEDIATION AND CONCILIATION SERVICE}

The national headquarters and all regional office buildings are leased from and operated by GSA. Energy consumption for gasoline totaled 118 million Btu for FY 1978, but after implementation of a fuel conservation program, was reduced to 25 million Btu for the first six months of FY 1979. FMCS is encouraging car pooling and is cooperating fully with GSA buildings managers to conserve energy in leased office space. The Federal Mediation and Conciliation Service (FMCS) leases two midsize cars from private sources.

\section{FEDERAL RESERVE SYSTEM}

The Federal Reserve System employs 1,459 persons and owns and operates two buildings and 13 automobiles. Energy conservation programs directed at the vehicle fleet resulted in a decrease of 14.6 percent in the total fuel used, while building energy use per gross square foot for electricity and steam increased by 34 percent from FY 1975 levels. Preliminary FY 1979 data shows a decrease in building energy consumed per gross square foot of nearly 47 percent below FY 1978 and 28.5 percent below FY 1975. Building retrofit efforts are in the final stage of completion and are anticipated to result in an additional five percent reduction in building energy use. Car pooling is encouraged with approximately 50 percent of the employees participating.

\section{FEDERAL TRADE COMMISSION}

The Federal Trade Commission (FTC) is a law enforcement agency with approximately 1,878 employees located in Washington, D.C., and in ten Regional Offices. All buildings occupied by the FTC are owned and operated by the General Services Administration. Energy conservation activities include thermostat adjustments in buildings and programs to reduce automotive gasoline use by ten percent. The FTC has a total of ten vehicles that are used for administrative purposes. In FY 1978, 26 percent less gasoline was used than for the base year FY 1975.

\section{FOREIGN CLAIMS SETTLEMENT COMMISSION OF THE UNITED STATES}

The Commission is an independent agency with 28 employees. The office space which it occupies (approximately 7,200 square feet) is leased. This space is located in a building containing several other agencies. Therefore, the Commission is not responsible for energy costs or conservation activities.

Early in FY 1979, the Commission terminated the rental of its only motor vehicle, replacing it with the use of messenger service. The agency no longer operates any vehicles. This has resulted in fuel conservation.

The Commission is aware of Federal conservation objectives and will continue promote them wherever possible.

\section{INTER-AMERICAN FOUNDATION}

Created by Public Law in 1969, the Foundation's mission is to support a wide range of development efforts in Latin America and the Caribbean. There are approximately 70 Federal employees. One sedan is leased from GSA and office space is leased from commercial sources. The Foundation encourages car pooling and requires the use of public transportation where available. 
INTERNATIONAL

\section{COMMUNICATION AGENCY}

The mission of the International Communica. tion Agency (USICA) is the promotion of mutual understanding between Americans and foreign peoples. The USICA maintains a total of 196 posts in 121 countries. Facilties in the United States include the Voice of America (VOA) radio stations, a headquarters staff, and support operations in New York City. With the exception of the radio stations, USICA is a tenant agency in GSA controlled buildings. The VOA relay stations are the largest users of energy in the agency, and a 20 percent energy use redućtion goal is in effect for nonprogram energy usage. The agency has a total of 18 vehicles in the United States, ten of which are leased from GSA.

Energy conservation programs include the procurement of compact vehicles, minimizing and combınıng vehicle trips, drlver tralning, and encouraging the use of car pools and mass transportation. Of a more unique nature, incandescent aircraft warning lights on transmitter towers at the Edward R. Murrow Transmitting Station were replaced with strobe units in Fy 1978 , resulting in energy savings of over 1.5 billion Btu per year and improved visibility of the towers from aircraft.

\section{INTERSTATE COMMERCE COMMISSION}

The Interstate Commerce Commission employs about 2,050 people at 60 building locations throughout the United States. These buildings are owned or leased by GSA. Accordingly, building energy consumption and cost information is not available to the ICC.

The ICC actively informs its employees of proper energy conserving procedures, including thermostat settings, vehicle fuel economy, and car pooling/van pooling.

The Commission has established a goal of reducing energy consumption by 15 percent, predominantly in the area of vehicle fuel consumption. In FY 1978, the ICC operated 175 vehicles. During the first half of FY 1979, the fleet was reduced to 159 vehicles. Accordingly, consumption is now at a rate about ten percent or more below that of FY 1978.
The ICC has adopted Flexitour hours to accommodate employee use of car pools and mass transit.

\section{MERIT SYSTEMS PROTECTION BOARD}

All building space occupied by the 308 employees of the Merit Systems Protection Board is leased from and controlled by GSA. The Board has been in existence since January, 1979 , and operated a total of four privately leased sedans. Directives to conserve energy in all the Board's operations have been transmitted to all employees.

\section{NATIONAL CAPITAL PLANNING COMMISSION}

The Commission is a Federal agency with 53 employees housed in GSA space in Washington, D.C. Administrative transportation is provided by one leased vehicle. The Commission does not have a formal in-house energy conservation program, but does attempt to conserve energy use in the daily conduct of business.

\section{NATIONAL CREDIT UNION ADMINISTRATION}

The National Credit Union Administration (NCUA) maintains its 650 employees in a Washington, D.C., office and in six regional offices all of which are leased from GSA. The 350 examiners of the NCUA utilize GSA or privately leased vehicles for all arministrative travel. $A$ program has been initiated to reduce travel requirements by ten percent. The agency participates in car pooling programs and solicits energy saving ideas from its employees.

\section{NATIONAL ENDOWMENT FOR THE ARTS}

The National Endowment for the Arts is a grants-making agency with a total employment of about 340 people. All building space is leased through GSA. The agency operates two vehicles: a pickup truck and a compact car. All parking permits are assigned to employee car 
pools. There is an active energy awareness training program which is supported by a series of posters and switch covers.

\section{NATIONAL LABOR RELATIONS BOARD}

All buildings and space occupied by the 3,000 employees of the NLRB are leased from and controlled by GSA. Transportation energy use is kept at a minimum through combining trips and the use of car pools, mass transportation, the telephone, and mail. In areas where heavy caseloads and corresponding heavy travel requirements have developed, the NLRB has opened new ulfices localed lo reduce overall transportation needs. The NLRB operates a continuing program of energy awareness education for its employees.

\section{NUCLEAR REGULATORY COMMISSION}

The Nuclear Regulatory Commission (NRC) is an agency of 3,000 people and has a total of 62 vehicles. Forty-three vehicles are leased from GSA, while the remainder are either com. mercially leased or owned by NRC. The motor vehicle fleet average fuel economy standard is being complied with, and 21 of the 62 vehicles are compact or subcompact sedans. The NRC is using gasoline in FY 1979 at a rate 30 percent lower than it did in FY 1978. This is being accomplished by increasing fleet fuel economy, careful evaluation of all motor trips, and an emphasis on public transportation to the maximum extent possible.

Voluntary energy conservation measures are practiced in NRC offices in cooperation with GSA, which leases and operates the buildings. The NRC supports the Washington Council of Government car pool program and has installed bicycle racks at their various buildings.

\section{NATIONAL SCIENCE FOUNDATION}

The GSA is responsible for services for the five leased buildings housing the NSF. The NSG has instituted several, energy conserva- tion measures including removal of all nonessential desk lamps, portable fans and heaters; also, unnecessary telephone installations are being reduced. The number of shuttle runs to annex buildings has been reduced, as has the length of time a parked vehicle may idle. Vehicle maintenance is regularly scheduled every six months. The Foundation has encouraged employee submissions of energy conservation suggestions.

\section{NATIONAL TRANSPORTATION SAFETY BOARD}

The National Transportation Safety Board promotes transportation satety by conducting independent investigations of accidents and formulating safety improvements. The Board has approximately 370 employees housed in space leased through GSA. A total of 41 vehicles are leased from GSA and one from a commercial source. The usage of automotive gasoline has increased since FY 1975 due to the number of vehicles required to fulfill the Board's mission.

\section{OCCUPATIONAL SAFETY AND HEALTH REVIEW COMMISSION}

The Review Commission was created in 1970 as an independent agency to adjudicate contested enforcement actions of the Occupational Safety and Health Administration of the Department of Labor. The Commission functions as a quasi-judicial independent Executive agency and employs approximately 175 individuals. All office space is occupied under GSA leases.

The Commission encourages car pools and promotes energy conservation among its employees. The two vehicles that were previously leased have been eliminated, and employees utilize public transportation or messenger services whenever possible.

\section{OFFICE OF MANAGEMENT AND BUDGET}

The Office of Management and Budget $(O M B)$ is housed in the Old and New Executive Office buildings in Washington, D.C. All space 
occupied by OMB is leased from and controlled by the General Services Administration. Vehicles previously assigned to $O M B$ were transferred to the Office of Administration, Executive Office of the President, and OMB now leases a total of two sedans for administrative purposes. Employee energy awareness and car pooling programs are conducted by the agency.

\section{OFFICE OF PERSONNEL MANAGEMENT}

The Office of Personnel Management was created January 1, 1979, as the successor to the U.S. Civil Service Commission. OPM's energy conservation program concentrates on heat and electricity and vehicular fuels. As OPM neither owns nor controls real property, and GSA is responsible for reporting, there are no reportable results in the heat and electricity area. OPM's efforts consist of cooperating with GSA in curtailing the use of energy in buildings. Two energy conserving actions redirected pedestrian building traffic during winter months to reduce the loss of building heat and turned off artificial lights in rooms and areas having adequate natural light.

The area of vehicular fuel is the only major energy component over which the agency has a significant degree of control. Gasoline consumption has been reduced through a concentrated effort by motor vehicle users to use energy conservation driving techniques and a rigid adherence to agency-wide quarterly mileage objectives. Gasoline consumption was reduced over 22 percent in FY 1978 compared to FY 1976. The agency's assumption that rigid mileage objectives would influence supervisors, operational, and administrative managers to review their daily activities for energy efficiency proved to be correct. The number of trips was reduced and one vehicle or one driver served where two vehicular trips would have been made previously. A shift to smaller, lighter vehicles has further aided OPM's gasoline conservation.

OPM has established goals to increase employee participation in wastepaper recycling and energy conservation awareness through posters, pamphlets, and administrative memorandums. OPM has also encouraged car pool and. van pool participation and the use of public transit for commuting and official activities.

\section{OVERSEAS PRIVATE INVESTMENT CORPORATION}

The Overseas Private Investment Corporation's 127 employees are housed in privately leased space. Two automobiles are used for administrative purposes. The Corporation is presently negotiating with its landlord to apply for solar films to the windows in an attemps to reduce solar heat transmission and improve employee comfort.

\section{PENNSYLVANIA AVENUE DEVELOPMENT CORPORATION}

The Pennsylvania Avenue Development Corporation (PADC) was established by Congress in 1972 to redevelop Pennsylvania Avenue and adjacent areas in Washington, D.C. The agency has no automobiles, and all building space is leased from GSA. In the course of its operations, the agency requires all developers to have an effective energy conservation program including, for example, the requirement for hotel developers to include energy saving devices and systems in their hotels. Energy awareness is encouraged among the 38 employees of PADC, and nearly all employees use public transportation or car pools to com. mute to and from work.

\section{PENSION BENEFIT GUARANTEE CORPORATION}

The 460 employees of the Pension Benefit Guarantee Corporation are located in buildings owned and operated by the General Services Administration. Administration transportation is limited to one leased station wagon providing official business transportation, mailmessenger services, and supply operation. Energy conservation programs include a comprehensive employee car pool program, limited flextime working hours, and the consolidation of photocopying services to reduce electrical power requirements. 


\section{RAILROAD RETIREMENT BOARD}

The U.S. Railroad Retirement Board administers the Railroad Retirement and Railroad Unemployment Insurance Acts and participates in the administration of the Health Insurance for the Aged Act insofar as it affects railroad retirement beneficiaries. The Board employs about 1,300 persons in a headquarters buildings and in 94 field offices. All building space is leased through GSA.

The total number of miles traveled by the Board's vehicles was three percent less in FY 1978 than in FY 1975. All vehicles are either leased through GSA or are privately owned. The Board's energy conservation goal for FY 1979 is to reduce the use of energy by five percent, and specific programs have been instituted to achieve this goal. The Board has an active program of employee energy awareness training and has implemented a wastepaper recycling program.

\section{SECURITIES AND EXCHANGE COMMISSION}

The Securities and Exchange Commission has seven vehicles; six leased from GSA, one from a commercial leasing firm. Since FY 1975, total energy use for all administrative vehicles has increased by 120 percent. This is due to the expanding role the SEC has in the regulation of the securities industry. All three headquarters buidings are leased from and controlled by GSA. The Commission participates with neighboring agencies in car pooling and van pooling programs and gives first priority for parking spaces within the building to car pools.

\section{SELECTIVE SERVICE SYSTEM}

The Selective Service System has been in a deep standby posture since October 1, 1976. Prior to that time, the Service had headquarters in each state, and in addition, about 900 area offices. Generally, office space was assigned by GSA, although some was state owned. Today, the Service has activities at nine locations, mostly on military installations.

Previously, the Service operated about 350 vehicles; today, only two automobiles are operated, both of which are assigned from the GSA motor pool. Trip and travel requirements are reviewed to minimize the one-person, onecar trip and to avoid nonessential travel.

As the Service has only 68 people assigned to it, there is no active program of energy education. The Director and Managers of the Selective Service System frequently demonstrate by example their concern for energy conservation. The Director has readjusted the training schedule for National Headquarters Reserve personnel to other than the summer months so as to eliminate the need for air conditioning of the Headquarter's office on weekends.

\section{SMALL BUSINESS ADMINISTRATION}

The Small Business Administration occupies approximately one million square feet of office space nationwide. GSA is directly responsible for the building facilities used by the SBA.

General transportation for the SBA's activities is provided by the Interagency Motor Pool System. Three hundred thirteen motor pool vehicles are assigned to the SBA on a full-time basis. In addition, two sedans are leased commercially for headquarters office use. The motor pool and leased vehicles accumulated $5,558,055$ miles and used an estimated 396,688 gallons of gasoline (49.6 billion Btu). This represnts a decrease in total mileage and fuel used of 48.5 percent compared to FY 1975.

The SBA has established a goal of further reducing automobile mileage and fuel consumption 10-15 percent from the previous year. This reduction is expected to be accomplished by reducing the use of government vehicles and by replacing medium-size sedans with smaller cars as they become available from the Interagency Motor Pool System. The SBA is also engaged in the Solar Energy Government Building Program.

\section{UNITED STATES ARMS CONTROL AND DISARMAMENT AGENCY}

The Arms Control and Disarmament Agency is a small agency consisting of less than 200 
permanent staff members, housed within the State Department buildings. The ACDA follows and endorses the State Department's efforts and directions on energy conservation and management. The only energy consumption over which the agency has control is the gasoline consumption in two leased automobiles. Unfortunately, adequate records of historical fuel use are unavailable. It is estimated, however, that the automobile fuel usage rate is about the same for the first half of FY 1979 as for FY 1978.

\section{U.S. COMMISSION ON CIVIL RIGHTS}

All of USCCR's offices are housed in GSA owned or leased buildings. The Commission has 279 employees.

The USCCR makes use of three automobiles, one leased from GSA, the other two from commercial sources. The FY 1978 estimate for gasoline consumption is 331 million Btu, with total energy costs at $\$ 2,200$. The estimate for gasoline consumption for the 1st half of FY 1979 is 165 million Btu. The agency has issued memoranda requiring elimination of unnecessary vehicle trips and consolidation of those considered essential. It has promoted the use of car pools and mass transit by adopting a flexible work schedule that allows employees to alter their working hours daily.

\section{U.S. CONSUMER PRODUCT SAFETY COMMISSION}

The mission of the Consumer Product Safety Commission is to protect the public against unreasonable risks of injury associated with consumer products. The Commission employs less than 1,000 persons in 13 area offices throughout the United States and in the Washington metropolitan area.

Nationally the Commission uses 111 vehicles, all but 14 of which are supplied by GSA. These 14 vehicles are leased. They consist of 13 subcompact vehicles and one passenger van. In FY 1978, the Commission's leased vehicles used 833.375 million Btu worth of gasoline at a cost of $\$ 4,000$. For the first half of FY 1979,
503.5 million Btu of gasoline has been used. In FY 1979, the Commission began operating its own interbuilding shuttle service which had formerly been operated by a contractor in prior years. In FY 1975, the gasoline used for vehi. cles leased by the Commission equalled 3,262.25 million Btu. The Commission states that its transportation and energy management program is in compliance with the President's memorandum of April 10,1979, requiring a five percent reduction in energy usage and a 10 percent reduction in the use of all motor fuels. The Commission issued several policy statement directing implementation of measures aimed at conserving energy in transportation. These policies included: using public mass transportation for local travel whenever possible, using government vehicles only for group travel or in. dividual travel to distant locations, leasing of vehicles in compliance with GSA-published fleet average miles per gallon standards, and traveling between the 18th Street Building in downtown Washington, D.C., and the Headquarters Building in Bethesda, Maryland, (north of the city) to be accomplished on the interbuilding passenger shuttle.

The Commission leases its building space through GSA which is responsible for building energy cost. To achieve a five percent reduction in energy use, several Commission-wide policies were implemented, including setting thermostats to more energy efficient temperatures, and quarterly walk-thruugh inspections of thermostats to ensure compliance with this policy.

The Commission has distributed "Tips for Energy Savere" to employees and eotablished car pool locators.

\section{UNITED STATES SOLDIERS' AND AIRMEN'S HOME}

The U.S. Soldier's and Airmen's Home (USSAH) occupies a facility of over 1.6 million square feet in Washington, D.C., including living quarters, offices, a chapel, hospital, and extensive maintenance and service buildings. There are approximately 1,020 personnel employed.

An active Energy Management Team has developed conservation measures and imple- 
mented a formal plan for the Home. All employees and members of the Home are involved in programs to meet goals of a five percent reduction in gasoline use and a ten percent reduction in heating oil use. The five Agency owned vehicles consumed one percent less fuel in Fy 1978 than in FY 1975. Electricity consumption has been reduced through the installation of an IBM System 7 energy management computer system which controls all lighting, ventilation, and exhaust fans. In FY 1978, electricity use was reduced by 5.9 percent and natural gas use was reduced 23.5 percent from the FY 1975 baseline. The only increase was in the use of heating oil which was nine percent higher than in FY 1975. This was due to winter heating needs being greater than normal. Initial data for FY 1979 indicates potential savings of over $\$ 50,000$ on electricity costs for the entire year, meeting the Home's cost avoidance goal of $\$ 50,000$ to $\$ 60,000$ annually.

The USSAH will experiment with a solar energy system to provide supplemental heat to its greenhouse during the winter season. 
THIS PAGE

\section{WAS INTENTIONALLY LEFT BLANK}




\section{APPENDIX C AGENCY ENERGY CONSERVATION OFFICERS}

The following personnel have been appointed by agencies as required by Section 656 of the Department of Energy Organization Act of 1977, Public Law 95-91. The list also included those personnel designated under 41 CFR 101-20.116.1. The function of the Principal Energy Conservation Officer is to oversee and supervise the government-wide effort as it pertains to the facilities under the agency's control.

Department of Defense

Housing and Urban Development

Department of Transportation

Department of Agriculture

Department of the Interior

U.S. Postal Service

General Services Administration

Department of Commerce
Robert B. Pirie, Jr. Assistant Secretary

Manpower, Reserve Affairs and Logistics

Father Geno C. Baroni

Assistant Secretary

Neighborhoods, Voluntary Associations, and

Consumer Protection

William Johnston

Acting Assistant Secretary

Policy and International Affairs

Weldon Barton

Assistant to the Secretary

Larry E. Meirerotto

Assistant Secretary

Policy, Budget, and Administration

Alfred C. Maevis

Assistant Postmaster General

Real Estate and Buildings

A. R. Marschall

Commissioner of Public Buildings Service

Elsa S. Porter

Assistant Secretary

For Administration

The Under Secretary of the Department of Energy, by letter of August 30, 1978, invited the National Aeronautics and Space Administration and the Veterans Administration to designate an energy conservation principal to participate in this group. The following officials have been designated:

\begin{abstract}
National Aeronautics and Space
Administration
\end{abstract}

Veterans Administration

\author{
E. C. Kilgore \\ Acting Associate Administrator for \\ Management Operations \\ Maury S. Cralle, Jr. \\ Assistant Deputy Administrator
}


Agency Energy Conservation Coordinators also have been appointed by major energy using agen. cies to carry out the policies and programs of the Principal Energy Conservation Officers. These Coordinators are primarily responsible for monitoring energy use in their agencies, implementing and managing programs, preparing quarterly and annual reports, and coordinating on energy conservation matters with other agencies and with the Department of Energy. The agency Energy Conservation Coordinators are:

\section{Agency}

Department of Agriculture

Civil Aeronautics Board

Office of Personnel Management

Department of Commerce

Department of Defense

Department of Energy

Environmental Protection Agency

Federal Communications Commission

General Scrvices Administration

Department of Health, Education and Welfare

Department of Housing and Urban Development

Department of the Interior Interstate Commerce Commission

Department of Justice

Department of Labor

National Aeronautics and Space Administration

National Science Foundation

Panama Canal Company/Canal Zone Government

U.S. Postal Service

Small Business Administration

Department of State

Tennessee Valley Authority

Department of Transportation

Department of the Treasury

Veterans Administration

\section{Energy Conservation Coordinator}

Mr. William Roth

Mr. Vince Chaverini

Mr. Ron Vergagni

Mr. Joseph Shallcross

Mr. William Sharkey, Jr.

Mr. Edward Tuttle

Mr. Jack Tarran

Mrs. Glenna F. Werking

Mr. Donald Winegarden

Mr. Richard Mendes

Mr. Charlie Williams

Ms. Cecile Bouchard

Mr. Stuart Davis

Ms. Barbara Spurlock

Mrs. Judith L. Tardy

Mr. Frank Durso

Mr. John E. Kirsch

Ms. Hazel Murdock

Mr. V. H. Hennessy

Mr. Samuel D. Chiles

Mr. Roland F. Gann

Mr. Allan Griswold

Mr. Lawrence Shipp

Mr. James Wright

Mr. Russell Struble 


\section{APPENDIX D AUTHORITIES - LEGISLATION, EXECUTIVE ORDERS, POLICIES AND REGULATIONS}

This appendix provides information on the legislation, executive orders, policies, and regulations that form the basic authorities for the Federal Energy Management Program and the related programs discussed in the body of this report. For convenience, these authorities are presented in three groups:

1. Authorities pertaining to the Federal Energy Management Program and to the conservation of energy in the Federal Government, including the National Energy Conservation Policy Act and Presidential Memoranda

2. The Energy Policy and Conservation Act (EPCA) of 1975 and supporting authorities

3. Authorities pertaining to Federal Procurement policies.

Following a brief discussion of the highlights of each authority, pertinent excerpts are provided in the attachments to this appendix.

\section{A. Executive Order 12003 Relating to Energy Policy and Conservation}

This executive order was issued July 20, 1977, and amended Executive Order 11912 of April 13, 1976, by the addition of a new section which clarified and expanded the requirement for a ten-year plan for energy conservation with respect to government buildings as provided for by Section 381(a) (2) of the EPCA. Section 2 of Executive Order 12003 authorized the Administrator of the Federal Energy Administration (now Department of Energy) to establish requirements and procedures, established goals for energy reduction in existing and new federally-owned buildings, provided for the development of a practical and effective method for comparing life cycle capital and operating costs, and directed the issuance of guidelines for building energy conservation plans to be submitted by all agencies. Details were provided regarding the content of such plans and their submittal to the Administrator of the Federal Energy Administration (now
Department of Energy). In addition to the buildings energy conservation plan, the President directed agencies to prepare an overall plan for conserving fuel and energy in all other agency operations.

The complete text of Executive Order 12003 is presented in Attachment A.

The complete text of Executive Order 12003 is presented in Attachment A.

\section{B. Executive Order 11912, Energy Policy and Conservation}

This Executive Order was issued April 13, 1976, and delegated the following authorities relating to Section 381 of the Energy Policy and Conservation Act:

- The development of the ten-year plan for energy conservation with respect to government buildings, as provided by Section 281(a)(2) of EPCA, was delegated to the Administrator of the Federal Energy Administration (now Department of Energy)

- The provision of policy guidance governing the application of energy conservation and efficiency standards in the Federal procurement process in accordance with Section 381(a)(1) of EPCA was delegated to the Administrator of the Office of Federal Procurement Policy (OMB)

- The preparation of the annual reports required by Section 381(c) of EPCA was delegated to the Administrator of the Federal Energy Administration (now Department of Energy).

The complete text of Executive Order 11912 is presented in Attachment B.

\section{C. Presidential Memorandum of February 2, 1979}

Signed by the President on February 2, 1979, this memorandum directed Executive departments and establishments to take immediate steps to reduce the use of petroleum fuels. All 
agency heads were required to establish goals, prepare plans, and issue necessary instructions to implement these plans. Department of Defense operational readiness activities were exempted.

The complete text of the memorandum is shown in Attachment C.

\section{D. Presidential Memorandum of April 10, 1979}

Signed by the President on April 10, 1979, this memorandum directed Executive departments and agencies to reduce consumption by five percent for the twelve month period beginning April 1, 1979, as compared with the preceding twelve months.

The complete text of the memorandum is shown in Attachment $D$.

\section{E. The National Energy Conservation Policy} Act (NECPA) 92 Stat. 3275, (1978), Title V. Part 3

Title V, Part 3, of the NECPA builds upon the approach of Executive Order 12003 for developing and implementing the 10-year Federal Buildings Energy Conservation Plan under EPCA. The NECPA requirements include:

- The establishment of practical and effective methods for estimating and comparing life cycle costs for Federal buildings

- Retrofit by 1990 of all Federal buildings for which preliminary energy audits have been performed. At least one percent of this work must be completed in 1980, with at least a further two percent in 1981 and at least an additional three percent in 1982

- The development of Federal building energy performance targets

- A preference in Federal agency leasing for buildings which use solar heating and cooling equipment or other renewable energy resources

- The use of solar heating and cooling and othe renewable energy sources in Federal buildings

- Identification of funds requested in the President's budget for retrofit measures undertaken under this part

- Periodic information from the Federal agencies to the Secretary of Energy on their progress and the submittal by the Secretary to the Congress of an annual report based on this information.

The full text of NECPA, Title V, Part 3, is shown in Attachment $E$.

1.F. Code of Federal Regulations Title 41-Public Contracts and Property Management, Chapter 101-Federal Property Management Regulation, Subchapter E-Supply and Procurement, Part 101-20.116, Conservation of Energy by Executive Agencies.

This regulation provides for each Executive agency to assign a top management official as the agency Energy Conservation Coordinator to oversee and supervise the government-wide effort as it pertains to the facilities under the agency's control. The regulation also provides detalls of lighting conservation policies and procedures, cooling and heating energy conservation policies and procedures, conserva. tion of energy in leased space, and reporting requirements.

The complete text of CFR Title 41, Chapter 101, Part 101-20.116 is shown in Attachment F.

\section{A. The Energy Policy and Conservation Act of 1975, Public Law 94-163}

This act was signed into law by the President on December 22; 1975. Section 381 of the Act provides the basic authority for the following:

- Development of mandatory standards with respect to energy conservation and energy efficiency to govern the procurement policies and decisions of the Federal Government

- Development and implementation of a tenyear plan for energy conservation with respect to buildings owned or leased by an agency of the United States

- Establishment and carrying out of a responsible public education program

- to encourage energy conservation and efficiency, or

- to promote van pooling and car pooling arrangements

The complete text of Section 381 of EPCA is shown in Attachment $G$. 
3.A. Policy Letter No. 76-1-Federal Procurement Policy Concerning Energy Conservation

Section $381(a)(1)$ of EPCA requires the establishment of Federal agency actions to develop mandatory standards with respect to energy conservation and energy efficiency to govern the procurement policies and decisions of the Federal Government and all Federal agencies. This authority was delegated by Section 3 of Executive Order 11912 to the Administrator of the Office of Federal Procurement Polic.

In response to this requirement, the Administrator of the Office of Federal Procurement Policy issued Policy Letter 76-1 on August 6, 1976 which directed the procedural implementation of this policy in Armed Services Procurement Regulations (now Defense Acquisition Regulations) and the Federal Procurement Regulations.

The complete text of Policy Letter 76-1 is shown in Attachment $H$.

\section{B. Defense Acquisition Regulation (DAR) 1.339-Energy Conservation}

In response to Policy Letter 76.1 issued by the Administrator of the Office of Federal Procurement Policy, DAR 1-339 was issued which directed that energy conservation and energy efficiency criteria should be applied in the determination of requirements, and source selection decisions whenever the application of such criteria would be meaningful, practical, and consistent with agency programs and operational needs. DAR 1.339 also directed that energy conservation and efficiency criteria should be considered for application along with price and other relevant factors in the preparation of solicitations, the evaluation of offers, and the selection of bids and proposals for award.

The complete text of DAR 1-339 is shown in Attachment I.
3.C. Federal Procurement Regulations, Subpart 1.1.3-General Policies, 1-1.339-Energy Conservation

Federal Procurement Regulations Subpart 1-1.3, General Policies, Section 1-1.339, Energy Conservation, was issued in response to Policy Letter 76.1 issued by the Administrator of the Office of Federal Procurement Policy. The regulations contained therein specify that energy conservation and energy efficiency criteria shall be applied in the determination of require. ments, and source selection decisions whenever the application of such criteria would be meaningful, practical, and consistent with agency programis and operational needs. Complete definitions of consumer products are also provided.

The complete text of Federal Procurement - Regulations, Subpart 1-1.3-General Policies, 1-1.339-Energy Conservation, is provided in Attachment $\mathrm{J}$.

3.D. Code of Federal Regulations Title 41-Public Contracts and Property Management, Chap. ter 101-Federal Property Management Regulations, Subchapter E-Supply and Procurement, Part 101.25-General Energy Conservatlon Pollcy

Pursuant to the provisions of Section $381(a)(1)$ of EPCA, the directive provides a basis for the promulgation of future directives with respect to energy conservation in supply management. Specifically, the rule directs that with respect to the procurement, or lease of, personal property or non-personal services, which in operation consume energy or contribute to the conservation of energy, executive agencies shall promote energy conservation and energy efficiency by being responsive to the energy efficiency and/or energy conservation standards or goals prescribed by the U.S. Government.

The complete text of CFR Title 41, Chapter 101, Part 101-25 is shown in Attachment $\mathrm{K}$. 
ATTACHMENT A

\section{PRESIDENTIAL DOCUMENTS}

\section{Title 3-The President}

\section{Executive Order 12003}

July 20,1977

\section{Relating to Energy Policy and Conservation}

By virtue of the authority vested in me by the Constitution and the statutes of the United States of America, including the Energy Policy and Conservation Act (89 Stat. 871, 42 U.S.C. 6201 et seq.), the Motor Vehicle Information and Cost Savings Act, as amended (15 U.S.C. 1901 et seq.), Section 205(a) of the Federal Property and Administratıve Serviċès Áct of $19 \dot{4} 4 \dot{y}$, as ameruded (40 U.S.C. $480($ a)), and Section 301 of Title 3 of the United States Code and as President of the United States of America, it is hereby ordered as follows:

SECTION 1. Section 1 of Executive Order No. 11912 of April 13, 1976, is amended to read as follows:

"Section 1.(a) The Administrator of General Services is desigriated and empowered to perform, without approval, ratification or other action by the President, the function vested in the President by Section 510 of the Motor Vehicle Information and Cost Savings Act, as amended (89 Stat. 915, 15 U.S.C. 2010). In performing this function, the Administrator of General Services shall:

(1) Promulgate rules which will ensure that the minimum statutory requirement for fleet average fuel economy is exceeded (i) for fiscal year 1978 by 2 miles per gallon, (ii) for fiscal year 1979 by 3 miles per gallon, and (iii) for fiscal years 1980 and after by 4 miles per gallon.

(2) Promulgate rules which will ensure that Executive agencies do not acquire, subsequent to fiscal year 1977, any passenger automobile unless such automobile meets or exceeds the average fuel economy standard for the appropriate model year established, by or pursuant to, Section 502(a) of the Motor Vehicle Information and Cost Savings Act, as amended (15 U.S.C. 2002(a)); except that, such rules (i) shall not apply to automobiles designed to perform combat-related missions for the Armed Forces or designed to be used in law enforcement work or emergency rescue work, and (ii) may provide for granting exemptions for individual automobiles used for special purposes as determined to be appropriate by the Administrator of General Services with the concurrence of the Administrator of the Federal Energy Administration.

"(b) The Administrator of General Services shall promulgate rules which will ensure that each class of nonpassenger automobiles acquired by all Executive agencies in each fiscal year, beginning with fiscal year 1979, achieve for such fiscal year a fleet average fuel economy not less than the average fuel economy standard for such class, established pursuant to Section 502(b) of the Motor Vehicle Information and Cost Savings Act, as amended (89 Stat. 903, 15 U.S.C. 2002 (b)), for the model year which includes January 1 of such fiscal year; except that, such rules (1) shall not apply to automobiles designed to perform combatrelated missions for the Armed Forces or designed to be used in law enforcement 
work or emergency rescue work, and (2) may provide for granting exceptions for other categories of automobiles used for special purposes as determined to be appropriate by the Administrator of General Services with the concurrence of the Administrator of the Federal Energy Administration."

SEC. 2. Executive Order No. 11912 of April 13, 1976, is further amended by adding the following new Section:

"Sec. 10.(a)(1) The Administrator of the Federal Energy Administration, hereinafter referred to as the Administrator, shall develop, with the concurrence of the Director of the Office of Management and Budget, and in consultation with the Secretary of Defense, the Secretary of Housing and Urban Development, the Administrator of Veterans' Affairs, the Administrator of the Energy Research and Development Administration, the Administrator of General Services, and the heads of such other Executive agencies as he deems appropriate, the ten-year plan for energy conservation with respect to Government buildings, as provided by section 381 (a)(2) of the Energy Policy and Conservation Act (42 U.S.C. 6361 (a)(2)).

(2) The goals established in subsection (b) shall apply to the following categories of Federally-owned buildings: (i) office buildings, (ii) hospitals, (iii) schools, (iv) prison facilities, (v) multi-family dwellings, (vi) storage facilities, and (vii) such other categories of buildings for which the Administrator determines the establishment of energy-efficiency performance goals is feasible.

"(b) The Administrator shall establish requirements and procedures, which shall be observed by each agency unless a waiver is granted by the Administrator, designed to ensure that each agency to the maximum extent practicable aims to achieve the following goals:

(1) For the total of all Federally-owned existing buildings the goal shall be a reduction of 20 percent in the average annual energy use per gross square foot of floor area in 1985 from the average energy use per gross square foot of floor area in 1975. This goal shall apply to all buildings for which construction was or design specificiations were completed prior to the date of promulgation of the guidelines pursuant to subsection (d) of this Section.

(2) For the total of all Federally-owned new buildings the goal shall be a reduction of 45 percent in the average annual energy requirement per gross square foot of floor area in 1985 from the average annual energy use per gross square foot of floor area in 1975. This goal shall apply to all new buildings for which design specifications are completed after the date of promulgation of the guidelines pursuant to subsection (d) of this Section.

"(c) The Administrator with the concurrence of the Director of the Office of Management and Budget, in consultation with the heads of the Executive agencies specified in subsection (a) and the Director of the National Bureau of Standards, shall establish, for purposes of developing the ten-year plan, a practical and effective method for estimating and comparing life cycle capital and operating costs for Federal buildings, including residential, commerical, and industrial type categories. Such method shall be consistent with the Office of Management and Budget Circular No. A-94, and shall be adopted and used by all agencies in developing their plans pursuant to subsection (e), annual reports pursuant to subsection (g), 
and budget estimates pursuant to subsection (h). For purposes of this paragraph, the term "life cycle cost" means the total costs of owning, operating, and maintaining a building over its economic life, including its fuel and energy costs, determined on the basis of a systematic evaluation and comparision of alternative building systems.

"(d) Not later than November 1, 1977, the Administrator, with the concurrence of the Director of the Office of Management and Budget, and after consultation with the Administrator of General Services and the heads of the Executive agencies specified in subsection (a) shall issue guidelines for the plans to be submitted pursuant to subsection (e).

"(e) (1) The head of each Executive agency that maintains any existing building or will maintain any new building shall submit no later than six months after the issuance of guidelines pursuant to subsection (d), to the Administrator a ten-year plan designed to the maximum extent practicable to meet the goals in subsection (b) for the total of existing or new Federal buildings. Such ten-year plans shall only consider improvements that are cost-effective consistent with the criteria established by the Director of the Office of Management and Budget (OMB Circular A-94) and the method established pursuant to subsection (c) of this Section. The plan submitted sliall specily appropriate energy-saving initiatives and shall estimate the expected improvements by fiscal year in terms of specific accomplishments - energy savings and cost savings - together with the estimated costs of achieving the savings.

(2) The plans submitted shall, to the maximum extent practicable, include the results of preliminary energy audits of all existing buildings with over 30,000 gross square feet of space owned and maintained by Executive agencies. Further, the second annual report submitted under subsection (g) (2) of this Section shall, to the maximum extent practicable, include the results of preliminary energy audits of all existing buildings with more than 5,000 but not more than 30,000 gross square feet of space. The purpose of such preliminary energy audits shall be to ideritify the type, size, energy use level and major energy using systems of existing Federal buildings.

(3) The Administrator shall evaluate agency plans relative to the guidelines established pursuant to subsection (d) for such plans and relative to the cost estimating method established pursuant to subsection (c). Plans determined to be deficient by the Administrator will be returned to the submitting agency head for revision and resubmission within 60 days.

(4) The head of any Executive agency submitting a plan, should he disagree with the Administrator's determination with respect to that plan, may appeal to the Director of the Office of Management and Budget for resolution of the disagreement.

"(f) The head of each agency submitting a plan or revised plan determined not deficient by the Administrator or, on appeal, by the Director of the Office of Management and Budget, shall implement the plan in accord with approved budget estimates. 
"'(g) (1) Each Executive agency shall submit to the Administrator an overall plan for conserving fuel and energy in all operations of the agency. This overall plan shall be in addition to and include any ten-year plan for energy conservation in Government buildings submitted in accord with Subsection (e).

(2) By July 1 of each year, each Executive agency shall submit a report to the Administrator on progress made toward achieving the goals established in the overall plan required by paragraph (1) of this subsection. The annual report shall include quantitative measures and accomplishment with respect to energy saving actions taken, the cost of these actions, the energy saved, the costs saved, and other benefits realized.

(3) The Administrator shall prepare a consolldated annual report on Federal government progress toward achieving the goals, including aggregate quantitative measures of accomplishment as well as suggested revisions to the ten-year plan, and submit the report to the President by August 15 of each year.

"(h) Each agency required to submit a plan shall submit to the Director of the Office of Management and Budget with the agency's annual budget submission, and in accordance with procedures and requirements that the Director shall establish, estimates for implementation of the agency's plan. The Director of the Office of Management and Budget shall consult with the Administrator about the agency budget estimates.

"(i) Each agency shall program its proposed energy conservation improvements of buildings so as to give the highest priority to the most cost-effective projects.

“(j) No agency of the Federal government may enter into a lease or a commitment to lease a building the construction of which has not commenced by the effective date of this Order unless the building will likely meet or exceed the general goal set forth in subsection (b)(2).

"(k) The provisions of this Section do not apply to housing units repossessed by the Federal Government".

Jimmy Carter

THE WHITE HOUSE, July 20, 1977.

[FR Doc: 77-21414 Filed 7-21-77;12:11 pm] 


\title{
Energy Policy and Conservation
}

ATTACHMENT B

\author{
Executive Order 11912
}

April 13, 1976

\section{Delegation of Authorities Relating to Energy Policy and Conșervation}

By virtue of the authority vested in me by the Constitution and the statutes of the United States of America, including the Energy Policy and Conservation Act (Public Law 94-163, 89 Stat. 871, 42 USC 6201 et seq.), the Motor Vehicle Information and Cost Savings Act, as amended (15 USC 1901 et seq.), the Defense Production Act of 1950, as amended (50 USC App. 2061 et seq.), and section 301 of Title 3 of the United States Code, and as President of the United States of America, it is hereby ordered as follows:

Section 1.(a) The Administrator of General Services is designated and empowered to perform without approval, ratification, or other action by the President, the functions vested in the President by section 510 of the Motor Vehicle Information and Cost Savings Act, as amended (89 Stat. 915, 15 U.S.C. 2010). In performing these functions, the Administrator of General Services shall consult with the Secretary of Transportation and the Administrator of the Federal Energy Administration.

(b) The Administrator of the Federal Energy Administration, in consultation with the Administrator of General Services and the Administrator of Energy Research and Development, shall coordinate the overall development of the 10-year plan for energy conservation with respect to Government buildings, as provided by section 381(a)(2) of the Energy Policy and Conservation Act (89 Stat. 939, 42 USC 6361(a)(2)). The Administrator of the Federal Energy Administration shall also consult with the Secretary of Commerce for the development of appropriate standards and technical criteria included in this plan. The heads of those Federal agencies that have the authority to construct, operate, manage, or lease Federal buildings shall prepare plans for buildings under the custody and control of, or leased by, such agencies. The Administrator of the Federal Energy Administration shall submit such plan to the President for his consideration.

Sec. 2. The Scorctary of Commerce is designated and empowered to perform without approval, ratification, or other action by the President, the functions vested in the President by section 103 of the Energy Policy and Conservation Act (89 Stat. 877, 42 USC 6212). In performing each of these functions, the Secretary of Commerce shall consult with appropriate Executive agencies, as set forth in the provisions of section 5(a) of the Export Administration Act of 1969, as amended (50 USC App. 2404(a)).

Sec. 3. The Administrator of the Office of Federal Procurement Policy, in the exercise of his statutory responsibility to provide overall direction of procurement policy (41 USC 405), shall, after consultation with the heads of appropriate agencies, including those responsible for developing energy conservation and efficiency standards, and to the extent he considers appropriate and with due regard to the program activities of the Executive agencies, provide policy guidance governing the application of energy conservation and efficiency standards in the Federal procurement process in accord with section 381 (a)(1) of the Energy Policy and Conservation Act (89 Stat. 892, 42 USC 6262 and 6263). 
Sec. 4. (a) The Administrator of the Federal Energy Administration, in consultation with the heads of approriate agencies, is hereby authorized and directed to develop for the President's consideration, in accord with section 201 of the Energy Policy and Conservation Act (89 Stat. 892, 42 USC 6261), the energy conservation and rationing contingency plans prescribed under section 202 and 203 of the Energy Policy and Conservation Act (89 Stat. 892, 42 U.S.C. 6262 and 6263).

(b) The Administrator of the Federal Energy Administration shall prepare, with the asșistance of the heads of appropriate agencies, for the President's consideration the annual reports provided by section 381(c) of the Energy Policy and Conservation Act (89 Stat. 939, 42 USC 6361 (c)).

Sec. 5. The Secretary of State is hereby delegated the authority vested in the President by Section 252(C)(1)(A)(iii) of the Energy Policy and Conservation Act (89 Stat. 895, 42 USC 6272(C)(1)(A)(iii)).

Sec. 6. The Administrator of the Federal Energy Administration is designated and empowered to perform without approval, ratification, or other action by the President, the functions vested in the President by:

(a) Section 251 of the Energy Policy and Conservation Act (89 Stat. 894, 42 USC 6271) except the making of the findings provided by subparagraph $(b)(1)(B)$ thereof; however, in performing these functions, the Administrator shall consult with the Secretary of Commerce with respect to the international allocation of petroleum products which are within the territorial jurisdiction of the United States; and provided that the Secretary of Commerce shall promulgate rules, pursuant to the procedures established by the Export Administration Act of 1969, as amended, to authorize the export of petroleum and petroleum products, as may be necessary for implementation of the obligations of the United States under the International Energy Program, and in accordance with the rules promulgated under Section 251 of the Energy Policy and Conservation Act by the Administrator pursuant to this subsection.

(b) Subsection 253(c) of the Energy Policy and Conservation Act (89 Stat. 898, 42 USC 6723);

(c) Section 254(a) of the Energy Policy and Conservation Act (89 Stat. 899, 42 USC 6274(a)), including the receipt of petitions under section 254(a)(3)(B); provided that, the authority under section 254(a) may be exercised only after consultation with the Secretary of State;

(d) Section 254(b) of the Energy Policy and Conservation Act (89 Stat. 900, 42 USC 6274(b)); provided that, in determining whether the transmittal of data would prejudice competition or violate the antitrust laws, the Administrator shall consult with the Attorney General, and in determining whether the transmittal of data would be inconsistent with national security he shall consult with the Secretaries of State and Defense, and the heads of such other agencies as he deems appropriate;

(c) Section 523(a)(2)(A) of the Energy Policy and Conservation Act (89 Stat. 962, 42 USC 6393(a)(2)(A)), but only to the extent applicable to other functions delegated or assigned by this Order to the Administrator of the Federal Energy Administration.

Sec. 7. (a) The Administrator of General Services is designated and empowered to perform without approval, ratification, or other action by the President, the functions vested in the President by section 101(c) of the Defense Production Act of 1950, as amended (89 Stat. 878, 50 USC App. 2071 (c)).

(b) The Administrator of General Services shall redelegate the functions provided by section 101(c)(1) of the Defense Production Act of 1950, as amended, to the 
Secretary of Commerce, who shall redelegate those functions, except the findings that the supplies are scarce and that it is necessary to exercise the authority provided by section 101(c)(1), to the Administrator of the Federal Energy Administration.

(d) The Administrator of General Services shall provide for the overall coordination and direction of the functions provided by section 101(c) of the Defense Production Act of 1950 , as amended, in a manner similar to the exercise of functions under sections 101(a) and (b) of that Act; except that, the Administrator shall first obtain the approval of the President if the implementation of any authority under section 101(c) of that Act would result in controlling the general distribution of materials in the civilian market, as that phrase is used in section 101(b) of that Act.

Sec. 8. Nothing in this Order shall be deemed or construed to limit the provisions of Executive Order No. 11790 of June 25, 1974, except that any action taken pursuant to the Defense. Prnduction Aot of 1950 ds amlended, requiring the allocation of, or priority performance under contracts or orders relating to supplies of materials and equipment in order to maximize domestic energy supplies shall be taken in accordance with the provisions of section 7 of this Order rather than Executive Order No. 11790.

Sec. 9. All orders, regulations, circulars or other directives issued and all other action taken prior to the date of this order that would be valid under the authority delegated by this Order, are hereby confirmed and ratified and shall be deemed to have been issued under this order.

The White House,

Gerald R. Ford

April 13, 1976

(Filed with the Office of the Federal Register, 4:50 p.m., April 13, 1976) 
THE WHITE HOUSE

WASHINGTON

February 2, 1979

\section{MEMORANDUM FOR THE HEADS OF}

\section{EXECUTIVE DEPARTMENTS AND AGENCIES}

\section{SUBJECT: Reduction of Energy Use by the Federal Government}

Because of the world shortfall in oil production resulting from the Iranian situation, I am directing that executive departments and establishments take immediate steps to reduce the use of petroleum fuels. For this purpose, all agency heads should establish goals, prepare plans and issue necessary instructions to implement them. The specific actions that ayeiricy lieads call lake include, but are not limited to, the following:

- Lowering thermostat settings in Federally owned and operated buildings to not more than 65 degrees during the day and 55 degrees during the night.

- Reducing electrical use generally throughout agency activities, particularly lighting.

- Reducing petroleum use by eliminating unnecessary activities and vehicle trips and combining and consolidating the essential ones.

- Reducing agency activities that use large amounts of energy and could be deferred, such as research and experimental activities that involve the use of highly energy intensive equipment.

In addition,.I urge all agency heads aggressively to pursue employee awareness programs on energy conservation, and to promote employee use of carpools and mass transit.

Agency heads should submit their goals and instructions for implementation to the Secretary of Energy by February 15, 1979. Agencies which currently submit quarterly reports on energy consumption to the Department of Energy should include in their FY 1979 second quarter report a statement showing energy savings accomplished from this special effort.

Department of Defense operational readiness activities are exempt from this directive.

Jimmy Carter. 


\section{THE WHITE HOUSE}

WASHINGTON

April 10, 1979

\section{MEMORANDUM FOR THE HEADS OF \\ EXECUTIVE DEPARTMENTS AND AGENCIES}

\section{SUBJECT: Required 5\% Reduction in Agency Energy Use}

The U.S. has taken the lead to gel the member nations of the International Energy Agency to reduce petroleum consumption. Our goal, as part of this commitment, is to reduce oil imports by a level equal and up to $5 \%$ of projected domestic consumption. This goal must be met to help reduce the upward pressure on world oil prices.

The Federal Government will do its part. I am directing that Executive departments and agencies reduce energy consumption by $5 \%$ for the twelve-month period beginning April 1, 1979, as compared with the preceding twelve months.

In achieving this reduction, the following specific actions are to be taken:

- Set thermostats in all Federally-operated buildings, except where required for health and safety or special purposes, at not more than 65 degrees during working hours and 55 degrees during non-working hours for the heating season and at not lower than 80 degrees for the cooling season.

- Reduce use of all automotive fuels by $10 \%$.

Each agency will have to take additional steps to achieve the full $5 \%$ reduction goal. These initiatives should be selected so as to avoid adverse programmatic impacts. As directed in my February 2, 1979 memorandum, tor example, heads of agencies may reduce lighting and other electrical use throughout agency activities and reduce petroleum use by eliminating unnecessary activities and vehicle trips. Credit will be given for fuel switching from oil to gas or coal.

Within 30 days, please submit to the Secretary of Energy a plan for achieving the reduction in energy use. Each agency that now reports quarterly energy consumption to the Secretary of Energy should identify in the quarlerly status reports the actual energy savings attributable to this effort.

I have directed the Secretary of Energy, in consultation with the Office of Management and Budget, to monitor compliance with the provisions of this directive. They will periodically report to me on accomplishments, problems with respect to adverse impacts on agency missions, and further actions which may be required. 


\section{TITLE V-FEDERAL ENERGY INITIATIVE}

\section{PART 3-ENERGY CONSERVATION AND SOLAR ENERGY IN FEDERAL BUILDINGS}

\section{SEC. 541. FINDINGS.}

The Congress finds that-

(1) there is an urgent need to promote the design, construction, and operation of buildings to conserve and make more efficierit use of fuels and energy;

(2) a shift from dependence on nonrenewable to renewable energy sources would have a beneficial effect on the Nation's overall energy supply;

(3) programs for energy conservation in buildings, along with the use of renewable energy sources, would stimulate industries arrd create new job opportunities for supply and servicing new or improved energy-conserving and energy-supplying systems and equipment;

(4) in the construction or renovation of buildings, the cost of energy consumed over the life of such buildings must be considered as well as the initial cost of such construction or renovation; and

(5) the Federal Government, the largest energy consumer in the United States, should be in the forefront in implementing energy conservation measures and in promoting the use of solar heating and cooling and other renewable energy sources.

\section{SEC. 542. POLICY}

It is the policy of the United States that the Federal Government has the upportunity and responsibility, with the participation of industry, to further develop, demonstrate, and promote the use of energy conservation, solar heating and cooling, and other renewable energy sources in Federal buildings.

\section{SEC. 543. PURPOSE.}

It is the purpose of this part to promote-

(1) the use of commonly accepted methods to establish and compare the life cycle costs of operating Federal buildings, and the life cycle fuel and energy requirements of such buildings, with and without special features for energy conservation, and

(2) the use of solar heating and cooling and other renewable energy sources in Federal buildings.

\section{SEC. 544. DEFINITIONS.}

For purposes of this part-

(1) The term "Secretary" means the Secretary of Energy.

(2) The term "life cycle cost" means the total costs of owning, operating, and maintaining a building over its useful life, including is fuel and energy costs, determined on the basis of a systematic evaluation and comparison of alternative building systems; except that in the case of leased buildings, the life cycle cost shall be calculated over the effective remaining term of the lease.

(3) The term "preliminary energy audit" means a determination of the energy consumption characteristics of an existing Federal building, including the size, 
type, rate of energy consumption and inajor energy üsing systems of such building and the climate characterizing the region where such building is located.

(4) The term "energy survey" means a procedure to be used in determining energy-conservation and cost savings likely to result from appropriate energy conserving maintenance and operating procedures and modifications, including the purchase and installation of particular energy-related fixtures to a Federal building.

(5) The term "Federal building" means any building, structure, or facility which is constructed, renovated or leased or purchased in whole or in part for use by the United States, and which includes a heating system, a cooling system, or both.

(6) The term. "construction" means construction and substantial reconstruction or renovation, as determined under rules prescribed by the Secretary.

(7) The term "energy performance target" means a rate of energy consumption which is the minimum practically achievable, taking into account life-cycle cost, by adjusting maintenance and operating procedures, or by modifying a Federal building's equipment or structure, or both.

\section{SEC. 545. ESTABLISHMENT AND USE OF LIFE CYCLE COST METHODS.}

(a) Establishment of Life Cycle Cost Methods. - The Secretary, in consultation with the Dlrector of the Office of Management and Budget, the Director of the National Bureau of Standards, and the Administrator of the General Services Administration, shall-

(1) establish practical and effective methods for estimating and comparing life cycle costs for Federal buildings; and

(2) develop and prescribe the procedues to be followed in applying and implementing the methods so established and in conducting preliminary energy audits required by section 547 .

(b) Use of Life Cycle Costs.-All new Federal buildings shall be life cycle cost effective as determined in accordance with the methods established under subsection (a). In the design of new Federal buildings, cost evaluation shall be made on the basis of life cycle cost rather than initial cost.

(c) Use in Non-Federal Structures. - The Secretary shall make available to the public information on the use of life cycle cost methods in the construction of buildings, structures, and facilities in all segments of the economy.

\section{SEC. 546. ENERGY PERFORMANCE TARGETS FOR FEDERAL BUILDINGS.}

The Secretary, in consultation with the Administrator of the General Services Administration, the Director of the National Bureau of Standards, and the Director of the Office of Management and Budget, shall establish ad publish energy performance targets for Federal Buildings, and shall take such actions as may be necessary or appropriate to promote to the maximum extent practicable achievement of such targets by Federal buildings. The performance targets established under the preceding sentence shall be compatible with energy conservation performance standards adopted or developed by the. Secretary of Housing and Urban Development for buildings.

\section{SEC. 547. ENERGY AUDITS AND RETROFITTING OF EXISTING FEDERAL BUILDINGS.}

(a) Audits of Buildings With 30,000 or More Square Feet.-As soon as possible after the date of the enactment of this part, each Federal agency shall conduct, 
to the maximum extent feasible, a preliminary energy-audit; of all. Federal buildings under its juridiction, occupancy or control which contain 30,000 or more square feet of floor space, and shall furnish the results of such audit to the Secretary. The Secretary shall submit to the Congress a full report on all preliminary energy audits conducted under this subsection no later than August 15, 1979.

(b) Audits of Federal Buildings With 1,000 or More But Less Than 30,000 Square Feet.-As soon as possible after the completion of the preliminary energy audits required under subsection (a) (and concurrently with such audits to the maximum extent feasible in the case of any agency), each Federal agency shall conduct a preliminary energy audit of all Federal buildings under its jurisdiction, occupancy, or control which contain 1,000 or more but less than 30,000 square feet of floor space, and shall furnish the results of such audit to the Secretary. The Secretary shall submit to the Congress a full report on all preliminary energy audits conducted under this subsection no later than August 15, 1979.

(c) Retrofit of Federal Buildings. - (1) Each Federal agency shall, in accordance with this subsection, select from each preliminary energy audit conducted by such agency under subsections (a) and (b) appropriate Federal buildings under its jurisdiction, occupancy, or control for retrofit measures to improve their energy efficiency in general and to minimize their life cycle cost. Such measures shall include, without being limited to, energy conservation measures, measures involving solar technology and other renewable energy resources, and any maintenance and operating procedures and particular energy-related modifications determined appropriate by an energy survey. In selecting the measures to be applied, Federal agencies shall give priority to changes in maintenance and operating procedures over measures requiring substantial structural modification or the installation of equipment.

(2) At least 1 percent of the total gross square floor footage contained in all Federal buildings which are under the jurisdiction, occupancy, or control of Federal agencies, and which are included in a preliminary energy audit conducted by such agencies under subsection (a) and (b) shall be retrofitted by such agencies under paragraph (1) pursuant to actions taken or arrangements made by such agencies during the first full fiscal year beginning after the date of the enactment of this part; and an additional percentage of such total gross square footage equal to at least 1 percentage point higher than the percentage applicable under this paragraph in the preceding year shall be so retrofitted pursuant to actions taken or arrangements made during the second and third such fiscal years, with a view to achieving full compliance with paragraph (3) by the time specified therein.

(3) On or before January 1,1990, all Federal buildings which are under the jurisdiction, occupancy, or control of any Federal agency shall be the subject of such retrofit measures under paragraph (1) as will assure their minimum life cycle costs.

\section{SEC. 548. LEASED FEDERAL BUILDINGS.}

In leasing buildings for its own use or that of another Federal agency, each Federal agency shall give appropriate preference to buildings which use solar heating and cooling equipment or other renewable energy sources or which otherwise minimize life cycle costs.

\section{SEC. 549. BUDGET TREATMENT OF ENERGY CONSERVING IMPROVE- MENTS BY FEDERAL AGENCIES}

Each Federal agency, in the preparation and submission of its requests to the Congress for appropriations, and authorizations for appropriations, for any fiscal 
year, shall specifically set forth and identify in a separate line item or items-

(1) the funds requested for retrofit measures to be undertaken under this part; and

(2) the portion of any other funds requested which represent to the maximum extent practicable the initial costs of construction or renovation attributable to capital equipment for energy conservation or the utilization of solar energy and other renewable energy sources.

\section{SEC. 550. REPORTS.}

Each Federal agency shall periodically furnish the Secretary with full and complete information on its activities under this part, and the Secretary shall annually submit to the Congress a comprehensive report on all activities under this part and on the progress made toward achievement of the objectives of this part.

\section{SEC. 551. AUTHORIZATION OF APPROPRIATIONS.}

There are authorized to be appropriated to the Secretary not to exceed $\$ 2$,000,000 for the fiscal year ending September 30,1979 , to enable him to perform the analytical and administrative functions vested in him under, this part.

\section{ATTACHMENT F}

\section{CHAPTER 101 - FED. PROPERTY MANAGEMENT REGULATIONS}

101-20.116 Conservation of energy by executive agencies.

(Sec. 205(c), 63 Stat. 390; 40 USC 486(c) and Federal Management Circular 741) (39 FR 39266, Nov. 6, 1974)

\section{1-20.116-1 Agency action.}

Executive agencies shall be responsible for assigning a top management official as the agency Energy Conservation Coordinator to oversee and supervise the Government-wide effort as it pertains to the facilities under the agency's control. It is further the responsibility of executive agencies occupying space in Government-owned or -leased quarters to require their employees to observe the energy conservation practices cited herein. Also, it should be noted that implementation of the provisions of this regulation may require consultation or negotiations, as appropriate, with recognized labor organizatione. (Sec. 205(c), 63 Stat. 380; 40 USC 486(c) and Federal Management Circular 74-1) (39 FR 39266, November $6,1974)$

101-20.116-2. Lighting conservation policies and procedures.

(a) Nonuniform lighting standards shall be applied to existing lighting systems by removing excess lamps and fixtures.

(1) During working hours, overhead lighting shall be reduced to 50 foot-candles at work stations, 30 foot-candles in work areas, and 10 (but not less than 1) footcandles in nonworking areas. Reductions in overhead lighting shall be accomplished with minimum practicable deviation from the specified levels. Illumination levels are to be measured at the place or places where the visual requirements are present. Furthermore, lighting measurements shall be made so as not to allow natural light to influence the foot-candle reading. Work station lighting measurements shall be taken at the desk surface, typewriter surface, working surface, etc. Work area lighting measurements shall be read on the walking surface. 
(2) Except where special problems may exist, an illumination level of 1 footcandle achieved on the walking surface at the center of the corridor midway between two lighting fixtures is satisfactory and need not be achieved at the corners of corridors, against corridor walls, etc.

(3) In stairwells where lamps or bulbs are provided in tandem to guard against darkening a stairway upon failure of one lamp or bulb, the tandem system shall be continued. In other words, the target lighting levels shall not be achieved by removing one of the two lamps or bulbs provided in the tandem system.

(4) Where elevator hoistway lights, and emergency lights, such as those to be illuminated by activation of an emergency generator are provided and required, then necessary lamps or bulbs shall be maintained. At least 5 foot-candles of illumination shall be provided at the landing sills of passenger and freight elevators when the elevator is in service.

(5) Off-hour and exterior lighting except that essential for safety and security purposes; e.g., exit signs, shall be eliminated.

(6) These standards shall be maintained in all space except where "heat of light" technology is utilized. Where "heat of light" technology is used, the energy savings to be achieved by decreasing the lighting and cooling energy shall be compared to the increased use of heating energy before a determination regarding delamping is made.

(b) To the extent that projected energy savings will offset higher acquistion and maintenance costs, preference shall be given to the installation of more efficient lighting systems when constructing or remodeling space.

(Sec. 205(c), 63 Stat. 390; 40 U.S.C. 486(c) and Federal Management Circular 74-1) [39 FR 39266, Nov 6, 1974]

\section{§ 101-20.116-3 Cooling and heating encrgy conscrvation policies and pro- cedures.}

(a) During the seasonably hot months, air cooling systems shall maintain space temperature at no lower than $78^{\circ}$ to $80^{\circ} \mathrm{F}$ during working hours. Necessary adjustments shall be made to cooling system controls so that the temperature in the space shall be maintained at $78^{\circ}$ to $80^{\circ} \mathrm{F}$ with no reheat, except in multizone systems where reheat is an essential element for zone control. Where this is the case, the cooling temperature shall be maintained as high as feasible to minimize the need for reheat. Furthermore, lower temperatures are permissable when obtained without cooling energy, such as with an economizer cycle. The use of heating energy to achieve the temperatures specified for cooling is prohibited.

(b) During the seasonably cold months, heating temperature control devices shall be set to maintain temperatures of $65^{\circ}$ to $68^{\circ} \mathrm{F}$ during working hours and shall be set to maintain temperatures of not more than $55^{\circ} \mathrm{F}$ during nonworking hours. Temperatures in warehouse and similar space shall be adjusted lower than the $65^{\circ}$ to $68^{\circ} \mathrm{F}$ range depending on the type of occupancy and the activity in the space. Higher temperatures than those specified for heating are permissable when obtained with normal building operation heat gains, such as solar energy, etc. The use of cooling energy to achieve the temperatures specified for heating is prohibited.

(1) Interior space in office buildings tends to have a heat build-up generated by lights, people, and equipment and therefore, does not usually require an added heat source during the heating season. Systems serving this type of space usually utilize recirculated air mixed with some outside air for ventilation pruposes. The amount of outside air shall not be increased nor refrigeration introduced for the 
sole purpose of lowering the temperature which might otherwise exceed $68^{\circ} \mathrm{F}$.

(2). Window draperies and blinds shall be used to cut down heat losses by setting them to the closed position during nighttime and on cold, cloudy days, and setting them to the open position during periods of sunshine.

(c) Humidity control shall not be provided for general office space during the cooling season. Requirements for humidity controls in special type space or certain geographic locations will be handled on an individual basis by the official responsible for operation and maintenance of the facility with the concurrence of the agency Energy Conservation Coordinator. Humidity controls may be provided during the heating season for general office space.

(d) The operation of threshold heaters, portable space heaters, and portable electric fans in Government-owned or -leased space is prohibited.

(e) Outside air intake during heating and cooling seasons shall be reduced to the greatest extent feasible. Under most conditions, a 10 percent outside air intake will be adequate for general office space. Under certain outside air temperature and humidity conditions, the use of up to 100 percent outside air will be the most economical method of operation. Special purpose space, such as laboratories, shall have the outside air intake reduced to the maximum extent possible consistent with the requirements of the mission. In laboratories and other facilities dealing with toxlc materlals, the level of air inlake and other system features shall be maintained as necessary to proted persons from harmful dust, fumes, vapors, etc.

(Sec. 205(c). 63 Stat. 390; 40 U.S.C. 486(c) and Federal Management Circular 74-1) [39 FR 39267, Nov. 6, 1974, as amended at 41 FR 6772, Feb. 13, 1976]

\section{§ 101-20.116-4 Exceptions.}

Exceptions to the policies prescribed in the foregoing $\S \S 101-20.116-2$ and 101-20.116-3 may be necessary for the protection and operation of certain specialized equipment; e.g., computers, for maintaining the health and efficiency of employees, and for certain installations of high specialization; e.g., greenhouses, hospitals, guard stations, and laboratories. Such exceptions may be granted only after consultation with appropriate technical personnel of the unit requesting the exception, and the presentation of necessary supporting cvidence. Exceptions will be granted by the office responsible for the operation and maintenance of the facility, and must be concurred in by the official's energy conservation coordınator. (Sec. 205(c), 63 Stat. 390; 40 U.S.C. 486(c) and Federal Management Circular 74-1) [39 FR 39267, Nov. 6, 1974]

\section{\$ 101-20.116-5 Conservation of energy in leased space.}

Contracting officers shall ensure that all new lease contracts include the conservation policies prescribed in $\S 101-20.116-2$ and $\S 101-20.116-3$. Existing lease contracts shall include the conservation policies prescribed in $\S 101-2.116-$ 2 and $\S 101-20.116-3$ to the extent feasible within the existing contract provisions or by amendment thereto.

(Sec. 205(c), 63 Stat. 390; 40 U.S.C. 486(c) and Federal Management Circular 74-1) [39 FR 39267, Nov. 6, 1974]

\section{§ 101-20.116-6 Reporting Requirements.}

(a) Each agency shall report the energy consumption in buildings and facilities under its control within 45 calendar days after the end of each quarter, as specified in the Federal Energy Administration Energy Conservation Performance Report, 
Form FEA U 502-0-0. Forms shall be mailed to the Federal Energy Administration, Mail Code 2898, Washington, D.C. 20461. In addition, a copy of the report shall be sent simultaneously to the Administrator of General Services, Washington, D.C. 20405.

(b) This report has been cleared in accordance with FPMR 101-11.11 and assigned interagency report control number 1492-FEA-OU.

(Sec. 205(c), 63 Stat. 390; 40 U.S.C. 486(c) and Federal Management Circular 74-1) [41 FR 6772, Feb. 13, 1976]

December 22, 1975

ATTACHMENT G

\section{PART E-OTHER FEDERAL ENERGY CONSERVATION MEASURES FEDERAL ENERGY CONSERVATION PROGRAMS 42 USC 6361.}

Sec. 381.(a)(1) The President shall, to the extent of his authority under other law, establish or coordinate Federal agency actions to develop mandatory standards with respect to energy conservation and energy efficiency to govern the procurement policies and decisions of the Federal Government and all Federal agencies, and shall take such steps as are necessary to cause such standards to be implemented.

(2) The President shall develop and, to the extent of his authority under other law, implement a 10-year plan for energy conservation with respect to buildings owned or leased by an agency of the United States. Such plan shall include mandatory lighting efficiency standards, mandatory thermal efficiency standards and insulation requirements, restrictions on hours of operation, thermostat controls, and other conditions of operation, and plans for replacing or retrofitting to meet such standards.

(b) (1) The Administrator shall establish and carry out a responsible public education program-

(A) to encourage energy conservation and energy efficiency; or

(B) to promote van pooling and carpooling arrangements.

\section{Definitions.}

(2) For purposes of this subsection:

(A) The term "van" means any automobile which the Administrator determines is manufactured primarily for use in the transportation of not less than 8 individuals and not more than 15 individuals.

(B) The term "van pooling arrangement" means an arrangement for the transportation of employees between their residences or other designated locations and their place of employment on a nonprofit basis in which the operating costs of such arrangement are paid for by the employees utilizing such arrangement.

\section{Report to Congress.}

(c) The President shall submit to the Congress an annual report concerning all steps taken under subsections (a) and (b). 


\title{
ATTACHMENT H
}

\section{EXECUTIVE OFFICE OF THE PRESIDENT OFFICE OF MANAGEMENT AND BUDGET WASHINGTON, D.C. 20503}

\author{
OFFICE OF FEDERAL \\ PROCUREMENT POLICY
}

POLICY LETTER NO. $76-1$

August 6, 1976

\section{TO THE HEADS OF EXECUTIVE DEPARTMENTS AND ESTABLISHMENTS}

\section{SUBJECT: Federal Procurement Policy Concerning Energy Conservation}

Public Law 94-163, the Energy Policy and Conservation Act, establishes a number of Federal energy conservation measures, one of which is to promote energy conservation and efficiency through procurement policies and decisions of the Federal Government. Responsibility for this program was delegated to me by Section 3 of Executive Order 11912, April 13, 1976.

In the furtherance of thls program, you are requested tu enisure that the principles of energy conservation and efficiency are applied in the procurement of property and services whenever the application of such principles would be meaningful and practicable and consistent with agency programs and operational needs. These principles may be appropriate for application, along with price and other relevant factors, in the formulation of purchase requests and solicitations and during the evaluation and selection of bids and proposals. In addition, with respect to procurement of consumer products, as defined under Part B of Title III (42 U.S.C. 6291) of the Energy Policy and Conservation Act, agencies should take cognizance of energy use/efficiency labels (42 U.S.C. 6294) and prescribed energy efficiency standards (42 U.S.C. 6295).

Specific procedural implementation of this policy will be promulgated in the Armed Services Procurement Regulation and the Federal Procurement Regulations.

Hugh E. Wirt

Administrator

ATTACHMENT I

\author{
ASPR 1-339
}

$[32,102.60]$

1-339 Energy Conservation

(a) The Energy Policy and Conservation Act requires that Federal procurement policies governing requirements determination and source selection decisions provide for consideration of (i) conservation of energy and (ii) the relative energy efficiency of alternative goods or services capable of satisfying the Government's needs. 
(b) The energy conservation and energy efficiency criteria shall be applied in the determination of requirements and source selection decisions whenever the application of such criteria would be meaningful, practical, and consistent with agency programs and operational needs. Under this policy, energy conservation and efficiency shall be considered for application along with price and other relevant factors in the preparation of solicitations, the evaluation of offers, and the selection of bids and proposals for award.

(c) With respect to the procurement of consumer products, executive agencies shall take cognizance of energy use/efficiency labels and prescribed energy efficiency standards as they become available.

[DPC No. 76-7(V), 79,063.]

\title{
ATTACHMENT J
}

\author{
Federal Procurement Regulations \\ (Second Edition, FPR Amendment 191, March 1978)
}

Subpart 1-1.3 General Policies

\section{1-1.339 Energy conservation.}

\section{1-1.339-1 Authority.}

(a) The Energy Policy and Conservation Act (42 USC 6361(a)(1)) provides as follows: "The President shall, to the exlent of his authority under other law, establish or coordinate Federal agency actions to develop mandatory standards with respect to energy conservation and energy efficiency to govern the procurement policies and decisions of the Federal Government and all Federal agencies, and shall take such steps as are necessary to cause such standards to be implemented."

(b) The authority of the President under the act was delegated by the President to the Administrator of the Office of Federal Procurement Policy in Executive Order 11912. The Administrator issued Policy Letter No. 76-1, which requested agencies “.... to ensure that the principles of energy conservation and efficiency are applied in the procurement of property and services whenever the application of such principles would be meaningful and practicable and consistent with agency programs and operational needs." It also provided for implementation of the policy in the Federal Procurement Regulations.

\section{1-1.339-2 Procedures.}

(a) Energy conservation and energy efficiency criteria shall be applied in the determination of requirements and source selection decisions whenever the application of such criteria would be meaningful, practical and consistent with agency programs and operational needs. Under this policy, energy conservation and efficiency criteria shall be considered for application along with price and other relevant factors in the preparation of solicitations, the evaluation of offers, and the selection of bids and proposals for awards.

(b) When procuring consumer products, executive agencies shall take into consideration energy use and efficiency labels and prescribed energy efficiency standards as they become available. 


\section{1-1.339-3 Definitions.}

(a) The term "consumer product" means any article (other than an automobile, as defined in section 501(1) of the Motor Vehicle Information and Cost Savings Act) of a type-

(1) Which in operation consumes, or is designed to consume, energy; and

(2) Which, to any significant extent, is distributed in commerce for personal use or consumption by individuals; without regard to whether such article of such type is in fact distributed in commerce for personal use or consumption by an individual.

(b) The term "covered product" means a consumer product of one of the following types:

(1) Refrigerators and refrigerator-freezers.

(2) Freezers.

(3) Dishwashers.

(4) Clothes dryers.

(j) Waler heaters.

(6) Room air-conditioners.

(7) Home heating equipment, not including furnaces.

(8) Television sets.

(9) Kitchen ranges and ovens.

(10) Clothes washers.

(11) Huminidifiers and dehumidifiers.

(12) Central air-conditioners.

(13) Furnaces.

(14) Any other type of product which the Secretary of Energy classifies as a covered product pursuant to 42 USC 6292(b).

(c) The term "energy use and efficiency label" means a label required to be provided by manufacturer of a covered product pursuant to 42 USC 6296.

(d) The term "manufacturer" means any person who manufactures a consumer product.

(e) The term "energy efficiency standard" means a performance standard -

(1) Which prescribes a minimum level of energy efficlency for a covered product determined in accordance with test procedures prescribed under 42 USC 6293; and

(2) Which includes any other requirements which the Secretary of Energy may prescribe under 42 USC 6295(c).

(f) The term "manufacture" means to manufacture, produce, assemble, or import. 


\section{RULES. AND REGULATIONS}

(6820-24)

Title 41 - Public Contracts and Property Management

CHAPTER 101 - FEDERAL PROPERTY MANAGEMENT REGULATIONS

SUBCHAPTER E - SUPPLY AND PROCUREMENT

(FPMR Amendment E-216)

PART 101-25 - GENERAL

\section{Energy Conservation Policy}

\section{AGENCY: General Services Administration}

ACTION: Final rule.

SUMMARY: Pursuant to the provisions of section 381(a)(1) of Pub. L. 94-163, Energy Policy and Conservation Act, this directive amends GSA regulations to include an energy policy statement. This directive takes the necessary action to comply with the public law by providing a basis for the promulgation of future directives with respect to energy coneervation in supply mailayement.

\section{EFFECTIVE DATE: March 3, 1978.}

\section{FOR FURTHER INFORMATION CONTACT:}

Mr. John I. Tait, Director, Regulations and Management Control Division, Office of the Executive Director, Federal Supply Service, General Services Administration, Washington, D.C. 20406, 703-557-1914.

The table of contents for Part 101-25 is amended by revising the following entry:

Sec.

101-25.112 Energy Conservation Policy

Subpart 101-25.1 - General Policies

\section{Section $101-25.112$ is revised as follows:}

101-25.112 Energy conservation policy.

(a) Agency officials responsible for procurement, management, and disposal of personal property and nonpersonal services shall ensure that pertinent procurement and property management documents reflect the policy set forth in (b), below, which has been established pursuant to Pub. L. 94-163, Energy Policy and Conservation Act. 
(b) With respect to the procurement or lease of personal property or nonpersonal services, which in operation consume energy or contribute to the conservation of energy, executive agencies shall promote energy conservation and energy efficiency by being responsive to the energy efficiency and/or conservation standards or goals prescribed by the U.S. Government.

(Sec. 205(c), 63 Stat. 390; 40 USC 486(c)).

NOTE - The General Services Administration has determined that this document does not contain a major proposal requiring preparation of an Inflation Impact Statement under Executive Order 11821 and OMB Circular A107.

Dated: February 16, 1978.

Jay.Solomon,

Administrator of General Services

(FR Doe. 78-5570 filed 3-2-78; 8:45 a.m.) 


\section{APPENDIX E FEDERAL BUILDINGS BY CATEGORY}

The building categories used in this report are based on those contained in Federal Property Management Regulations, Amendment No. A-1, December 1964, Subpart 101-3.49; Section 101-3.4901-1166, GSA Form 1166: Annual Report of Real Property Owned by the United States. The classification of a buiding is determined by its predominant usage, and the building usage categories are defined as follows:

Office Buildings: Buildings used primarily for office space.

Hospitals: Buildings used primarily for furnishing in-patient diagnosis and treatment under the supervision of physicians and which have 24-hour-a-day registered graduate nursing services. Includes medical laboratories used in routine testing: Buildings used for basic or applied medical research should be reported under Research and Development.

Prisons: Buildings used for the confinement of Federal prisoners.

Schools: Buildings used for formally organized instruction, such as schools for dependent children, Indian schools, and military training buildings.

Other Institutional Buildings: Buildings used for institutional purposes other than hospitals, prisons and schools. Include libraries, chapels, museums, out-patient clinics, etc.

Housing: Buildings used primarily for dwelling purposes. Include single family and row houses, apartment houses, barracks, housing for military personnel, housing for personnel in Federal agencies, and housing for institutional personnel.

Storage Buildings: Buildings used primarily for storage purposes. Include warehouses, ammu- nition storage, cover sheds, and buildings used for the storage of vehicles or materials.

Industrial Buildings: Buildings used primarily for production or manufacturing operations. Include buildings used for the production or manufacture of ammunition, vehicles, equipment, chemicals and laboratories used for the routine testing of industrial products.

Service Buildings: Buildings used in connection with service activities. Include maintenance and repair shops, laundry and dry cleaning plants, post exchanges, stores, airport hangers, and garages used primarily for vehicle maintenance and repair.

Research and Development: Buildings used for basic or applied research in the sciences, medicine and engineering. Include buildings used in the design, development and testing of prototypes and processes, medical laboratories, and observatories for meteorological research. Do not include medical or industrial laboratories used in routine testing which should be included in Hospital and Industrial, respectively.

Utility Buildings: Buildings used to house equipment providing electric, heat, water, sewage, and telephone services. Include heating and cooling plants, sewage treatment plants, pump houses, electrical switch buildings and water treatment plants. Buildings utilized by a facility in the production of its own power requirements (not power for resale) shall be included in this category.

All Other Buildings: Include here all buildings which cannot be classified in any of the above categories. 
THIS PAGE

\section{WAS INTENTIONALLY LEFT BLANK}




\section{APPENDIX F BTU EQUIVALENTS FOR VARIOUS FUELS}

\begin{tabular}{l} 
Fuel Category \\
\hline Fuel Oil \\
Natural Gas \\
Liquified Petroleum \\
Gas (including \\
Propane \& Butane) \\
Coal \\
Purohased Steam \\
(source) \\
Automotive Gasoline
\end{tabular}

Btu Content Per Unit

138,700 Btu/Gallon

1,031 Btu/Cubic Foot

95,500 But/Gallon

24,580,000 Btu/

Short Ton

1,390 Btu/Pound

125,000 Btu/Gallon
Diesel and Petroleum Distillate Fuels

Aviation Gasoline

Jet Fuel

Navy Special Fuel Oil

Electricity (source)

Crude Oil Equivalent
138,700 Btu/Gallon

125,000 Btu/Gallon $130,000 \mathrm{Btu} / \mathrm{Gallon}$ $138,700 \mathrm{Btu} / \mathrm{Gallon}$ 11,600 Btu per Kilowatt Hour, including fuel consumed at the power plant

5,800,000 Btu/Barrel 

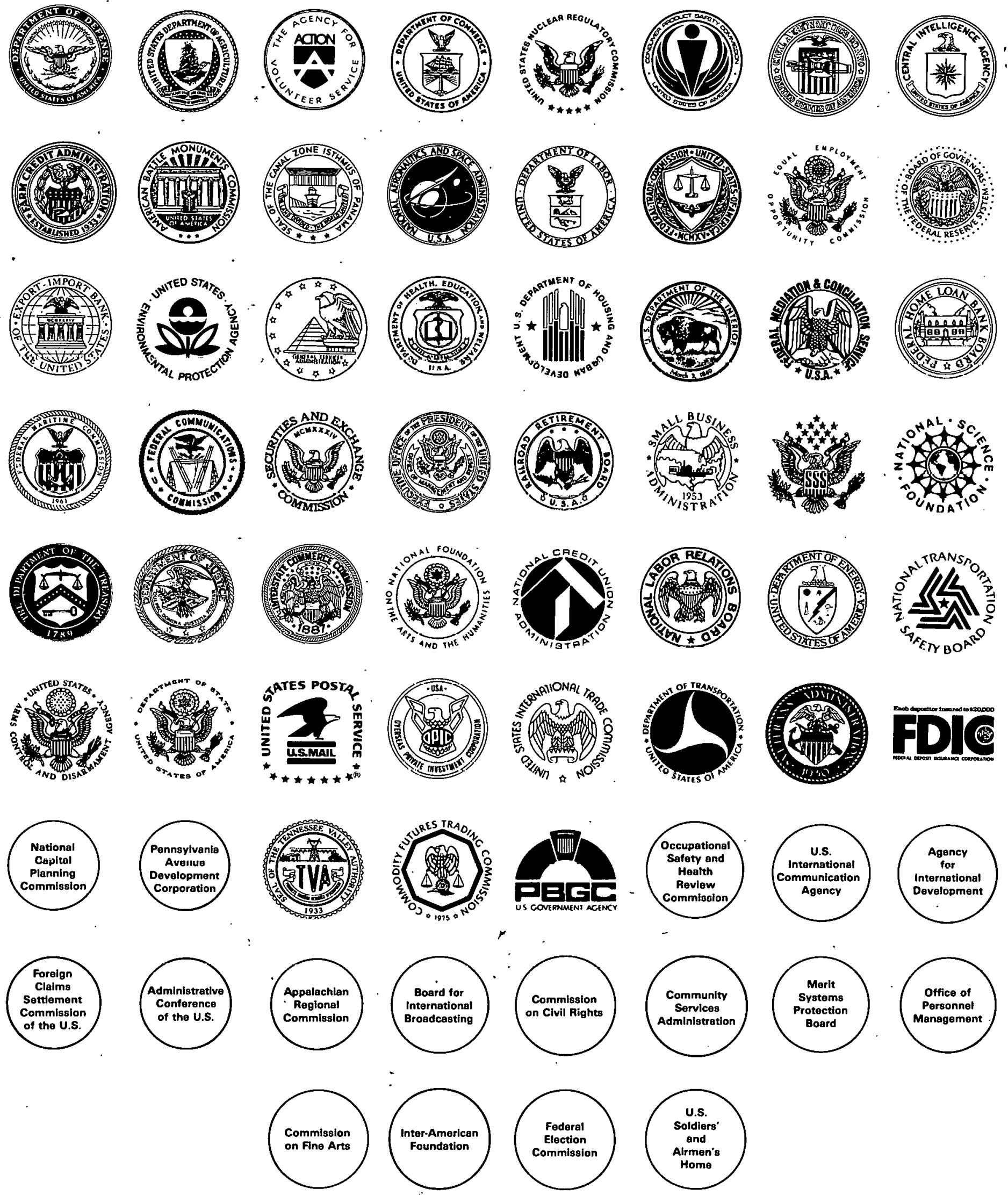